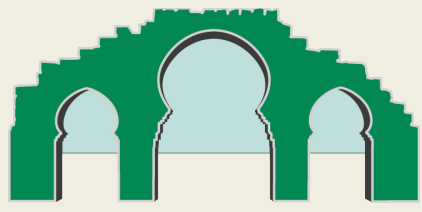

argelina.org
Revista Argelina

Revista semestral de Estudios Argelinos

\section{Otoño 2018}

Número 7

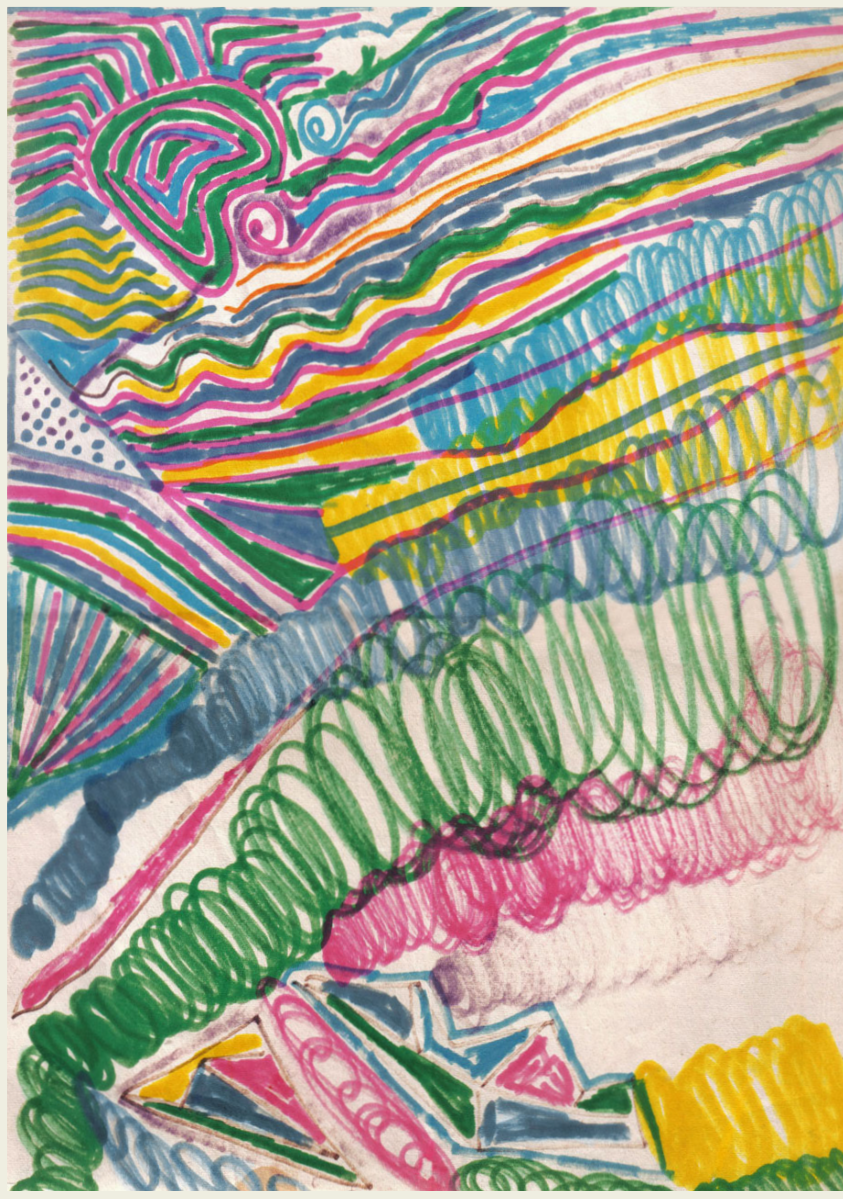


Número 7 • Otoño 2018

\section{Revista Argelina}

Revista semestral de Estudios Argelinos 



\section{Revista Argelina}

Revista semestral de Estudios Argelinos

Número 7

Comité editorial:

Directora: Naima Benaicha Ziani

Subdirector: Isaac Donoso

Editora: Oum Hani Rahmani

Secretario técnico: Didac Conesa

\section{Comité científico:}

Emilio Sola

Universidad de Alcalá de Henares

Abdallah Hammadi

Universidad de Constantina

Juan Martos Quesada

Universidad Complutense de Madrid

Carmen Barceló

Universidad de Valencia

Miguel Ángel Manzano

Universidad de Salamanca

Danielle Pister-López

Universidad de Lorraine

Fernando de Ágreda Burillo

Biblioteca Islámica-AECID 


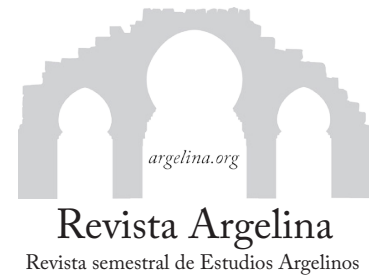

Revista Argelina. Revista semestral de Estudios Argelinos es una publicación electrónica semestral editada por el Área de Estudios Árabes e Islámicos de la Universidad de Alicante que edita dos números anuales de investigación y reflexión en torno a las letras, cultura, historia y actualidad de Argelia. Una versión extendida de la revista se publica en papel por la Editorial Hispano-Árabe.

\section{Exención de responsabilidad:}

Las opiniones y datos contenidos en cada texto son de exclusiva responsabilidad de sus autores. Revista Argelina no comparte necesariamente las opiniones vertidas por los autores ni se hace responsable de los trabajos.

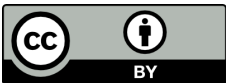

licencia de Creative Commons

Reconocimiento 4.0 Internacional.

(C) De los autores de los artículos originales.

(C) Revista Argelina, 2018

ISSN: 2444-4413

La revista esta disponible a texto completo en internet en:

https://argelina.ua.es

http://argelina.org

Portada:

Dibujo original realizado por Marcelino Villegas

Imprime:

Editorial Hispano-Árabe

http://www.editorial-hispanoarabe.com

Calle de los Jazmines No 17

Talamanca de Jarama

28160 Madrid

Tel. 639707720 


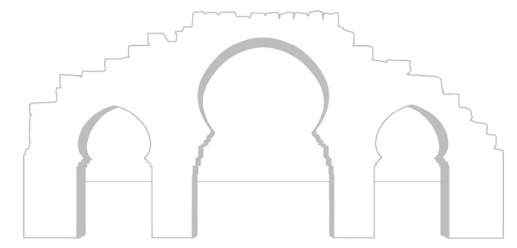

Revista Argelina · Número 7 · Otoño 2018

Índice

\section{Ensayos}

Souad Hadj-Ali Mounoub

El ritual de la boqala. Una tradición oral argelina

Mohammed Yousfi

Relaciones políticas entre Argelia y España antes de la colonización francesa

Artículos y notas

Mourad Kacimi

Análisis crítico sobre el Nafh al-țîb min-guṣn al-Andalus al-rațīb de al-Maqqarī 25

Djamel Latroch

Malteses en Argelia (1833-1900): entre el rechazo y la aceptación

Faiza Mechernene

El léxico español en Aïn Temouchent .73

Antonio Torres Fernández

Traduciendo a Wāsīnī al-A'raŷ: un estudio mitocrítico del dualismo léxico en su obra Bayt al-Andalusī 101

IsAac Donoso

Argelia y los estudios árabes en Alicante (III): Marcelino Villegas

Sarra Ikram Hadef

Carta del miquilache Sidi Hasán (1786): edición y traducción

Muhammad Ben Zagadi

Aproximación geográfica e histórica a la ciudad de Nedroma

Taher Abbassa, Mohammed Yousfi y Rabia Ben Azzouz

La contribución del arbitraje comercial internacional para activar la seguridad jurídica de las inversiones argelinas en el extranjero 155

\section{Reseñas y comentarios bibliográficos}

Óscar Abenojar, Ouahiba Immoune y Fatima-Zohra Menas, La princesa cautiva y el pájaro del viento. Mitos y cuentos del norte de Argelia (A. Torres Fernández). 175 


\section{Biblioteca}

La historia de Harún Al-Rashid. Narrada por Mohammed Kandouci (1925-2008).Grabada, transcrita y traducida del árabe al castellano por Laredj Kandouci .......................... 181

El roble del Ogro. Cuento traducido por Assia Abdi Amamouri .................................. 189 


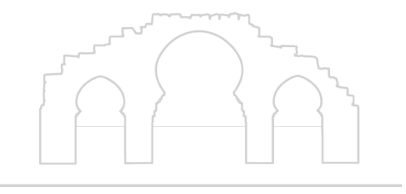

Ensayos 



\title{
EL RITUAL DE LA BOQALA. UNA TRADICIÓN ORAL ARGELINA
}

\author{
Souad Hadj-Ali Mouhoub
}

En la tradición argelina, el mes de Ramadán es una buena ocasión para que las familias y los amigos se reúnan, tras la cena, alrededor de una mesa repleta de pastelitos caseros y té, para charlar, contar cuentos, etc. Pero una de las actividades más atrayentes es la recitación de poesías femeninas cortas que auguran el futuro de los participantes. Estas poesías se llaman boqalat (plural de bogala).

El ritual de la boqala pertenece a la tradición oral femenina argelina. Según el especialista argelino en este género literario oral, Kaddour M'Hamsadji, la bogala se remonta a finales del siglo XVI, período en el que "Argelia estaba en pleno apogeo político, cultural y económico y en el que la lengua árabe poseía toda su riqueza y viveza"1.

Se trata de unos poemas anónimos cortos, de 4 ó 6 versos, que forman un extenso repertorio en árabe argelino creado por mujeres. Éstas suelen organizar sesiones de boqala para pasar el tiempo, lo que les permite establecen entre sí una especie de diálogo poético, una interacción que les permite comunicar sus alegrías, sus penas y angustias gracias al mensaje del texto recitado de memoria o improvisado en el instante, inspirado por el contexto o por el estado de ánimo de su creadora.

El nombre del ritual viene de la palabra argelina «boqala» que significa cuenco de barro, utensilio imprescindible para este juego. En efecto, dicho cuenco se llena de agua y en él las participantes colocan cada una un anillo o algún pequeño objeto que la identifique. Antes de que se inicie la recitación del poema, una persona entre los asistentes coge al azar uno de los objetos que se encuentran en el cuenco de manera que el significado de la boqala y lo que simbolice se atribuya a su propietaria.

En general los poemas transmiten buenos augurios (insinúan felicidad, amor, fertilidad, viajes...), aunque algunos transmiten malos presagios

1 Le jeu de la boûqâla, Argel, Office des Publications Universitaires, 2002. 
(anunciando separación, desamor o engaño y traición).

Las boqalat que vienen a continuación están sacadas del libro titulado El ritual de la boqala. Poesía oral femenina argelina ${ }^{2}$, de cuya edición me encargué personalmente y cuyos poemas traduje al castellano ${ }^{3}$.

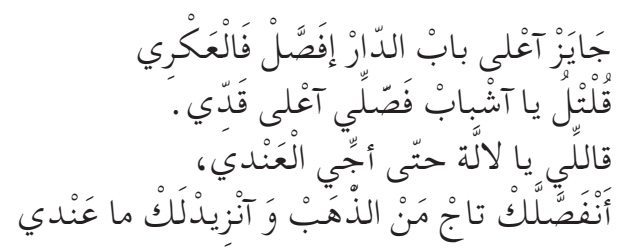

Pasaba por mi puerta cortando seda flamante.

Le dije: «Galán, haz a mi medida el corte».

Me dijo: «Así será, mas si vienes hacia mí

te daré una diadema de oro y todo lo mío para ti».

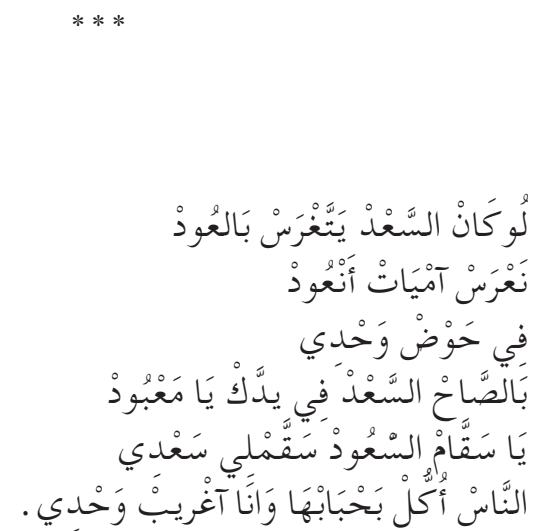

Si la felicidad cultivar pudiera,

plantaría yo solo mil y una

mas la felicidad en tu poder está

2 El ritual de la boqala. Poesía oral femenina argelina, Madrid, Cantarabia, 2011.

3 Véase también mi artículo "Literatura oral argelina: reflexión sobre un proceso de traducción", BLO, 2015, núm. 5, pp. 35-44. 
Dios de la Misericordia

Tú que repartes la suerte,

dame la mía, te lo ruego,

cada cual con su gente

y yo solo voy sin nadie.

Dueña del jardín,

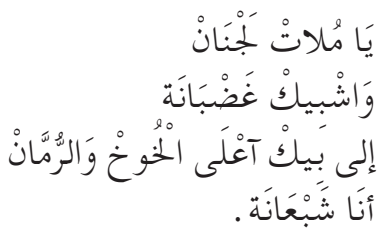

¿por qué te enfadas?

si es por sus frutas,

yo estoy saciada.

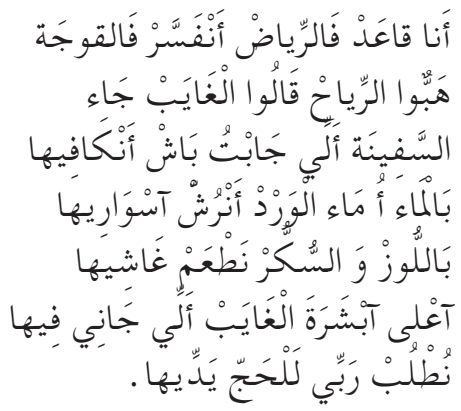

Sentado en el jardín, yo meditaba, corría la brisa fresca, al ausente anunciaba.

Este navío que le trae, ¿con qué lo recibiré? con agua y flor de azahar, yo lo perfumaré, almendras y azúcar a su gente ofreceré Dios clemente, te ruego, guíalo hacia Oriente. 
12 Sound Hadj-Ali Mounoub

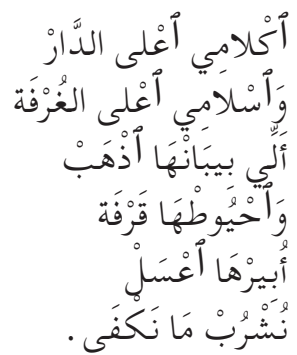

Aunque hable de la casa, al cuarto va mi saludo, sus paredes son de canela y sus puertas son de oro, pero nunca me saciará la miel que sale del pozo.

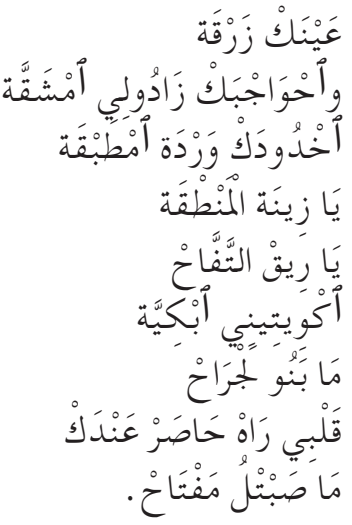

Ay, de tu mirada azul bajo el arco de tu ceja, ay, de tu mejilla en flor, oh, tú, la más hermosa. 
¡Ay, sabor a manzana!
de tu fuego quemado estoy
mas suave la quemadura,
posees tú mi corazón
y no tengo escapatoria.

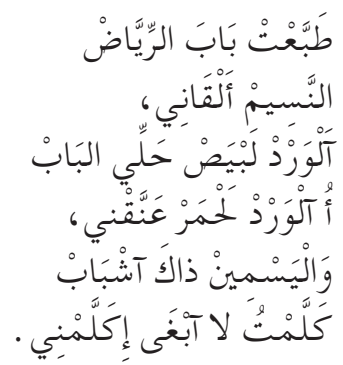

Abrí la puerta del jardín y me recibió la brisa, me acogió la flor carmín, me abrazó la rosa blanca, hablé con el bello jazmín, mas no quiso decir nada.

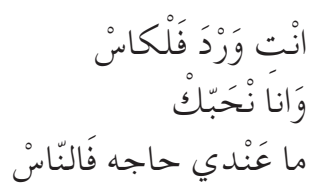

Eres una rosa en un vaso

yo cuánto te amo

y de todo el mundo paso. 
14 Souad Hadj-Ali Mounoub

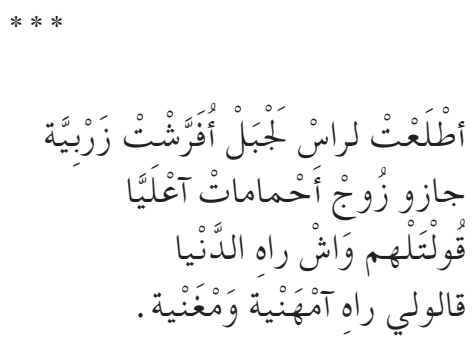

En lo alto de la montaña

extendí una alfombra

dos palomas pasaron

encima de mí volaron

les pregunté qué tal la vida

dijeron apacible y rica.

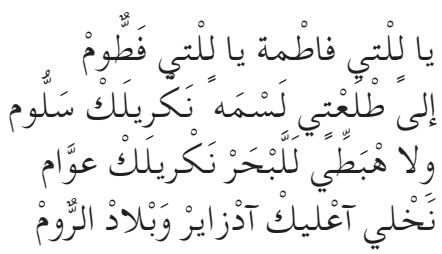

Noche de mi Fatma, Fatma noche mía

si vuelas hacia el cielo

subiré mil peldaños

si te hundes en la mar

estaré en su fondo

iré siempre en tu busca

desde Argel hasta Roma. 


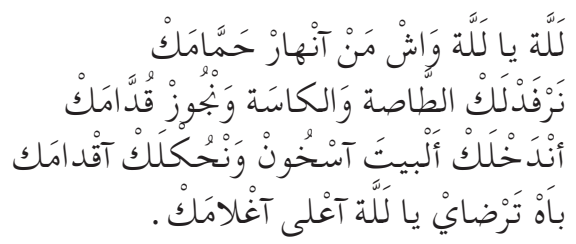

Ay, Señora, Señora mía, ¿cuándo es su día de baño? para estar a su lado y llevar sus enseres penetrar en su cuarto y lavarle los pies para que de mí tenga mucha piedad, Señora. 



\title{
RELACIONES POLÍTICAS ENTRE ARGELIA Y ESPAÑA ANTES DE LA COLONIZACIÓN FRANCESA
}

\author{
Mohammed Yousfi \\ Universidad de Mostaganem
}

\section{INTRODUCCIÓN}

La piratería marítima en los países mediterráneos constituyó un marco legal fundacional, en el sentido de representar para el Estado sus bases jurídicas y la razón de su existencia para defender un territorio. Argel era una ciudad con un gran puerto donde coexistían todas las nacionalidades del espacio mediterráneo. Su periferia alojaba a todo tipo de individuos que vivían directa o indirectamente del corso. Y eso se refleja en numerosos tratados de "paz y amistad" firmados entre Argelia y varios países del mundo. No obstante, el conflicto hispano-argelino se intensificó a principios del siglo XVIII, entre I707 y I7Io.

Desde entonces la relación entre los dos países consistió en campañas militares y operaciones corsarias, como la campaña de José Carrillo de Albornoz, duque de Montemar, del 15 de junio al 2 de julio de 1732. La expedición española de Orán y Mazalquivir de I732 terminó con la victoria de los españoles frente a la guarnición otomana. En un primer momento el control de las áreas y camino entre el puerto y la ciudad de Orán fue cortado por militares españoles. El 30 de junio fue ocupada la ciudad de Orán.

Habría que señalar después la gran campaña de Alejandro O’Reilly en I775 para tomar la ciudad de Argel. Concentradas las fuerzas en el puerto de Cartagena en junio de I775, la campaña terminó en estrepitoso fracaso, y el regreso de la maltrecha tropa al puerto de Alicante el i4 de julio. Como resultado de estas confrontaciones y varias otras razones relacionadas con los intereses estratégicos de los dos países, España entró en una nueva etapa con Argelia, a saber, entablar negociaciones de paz ${ }^{1}$.

1 Véase el trabajo clásico de Míkel de Epalza, “Intereses árabes e intereses españoles en las paces hispano-musulmanas del siglo XVIII», Anales de Historia Contemporánea, Universidad de Murcia, 1982, núm. 1, pp. 7-17. Existe una reciente tesis argelina de máster que trata dicho tema: Hamza 
Relaciones políticas y diplomáticas entre España y Argelia

La diplomacia exterior argelina ha adoptado históricamente dos principios básicos: en primer lugar, cada país es considerado enemigo hasta que sea firmado expresamente un tratado de amistad y paz; en segundo lugar, cualquier tratado que no reconozca la soberanía de Argel en el mar Mediterráneo es rechazado.

El dey Muḥammad bin 'Utmān Pacha (I71o-I79I)² rechazaba, de manera categórica, cualquier reconciliación con los españoles mientras controlasen Mazalquivir y Orán. Sin embargo existían factores políticos, económicos, militares y otros personales que hicieron que cambiara de opinión y se inclinara por la paz y la reconciliación con España. El primer factor era que Marruecos y Túnez habían aprobado un convenio de reconciliación con España; El segundo las consecuencias de las reiteradas incursiones españolas, a pesar de sus fracasos, en el estado anímico del dey y los responsables del Estado. La persistencia española aconseja estudiar las condiciones de la paz, así como la aparición de nuevos actores en el Mediterráneo.

La situación española también había cambiado, pues quien dirigía la política en ese momento era el murciano José Moñino Redondo (I728I808), conde de Floridablanca. Caracterizado por una personalidad conciliadora e imbuido por el pensamiento liberal y anticlerical, pretendía fomentar una política de diálogo y negociación para resolver problemas y conflictos externos por medios pacíficos, a través de la aprobación de tratados y acuerdos, incluso si estos tratados se acompañaban de concesiones financieras o geoestratégicas, como es el caso del argelino.

Sobre esta base se aseguró la necesidad de lograr una paz general con los países del Magreb, sobre todo Argelia, que era el país más fuerte de

Al-Abyad y Mokhtar Rabouh, Paces españolas en Argelia durante el siglo XVIII, Centro Universitario de Ghardaia, 2013-2014.

2 Tomó el cargo tras el mandado del dey Baba Alí. Fue conocido por su estabilidad y preferencia por el interés público. Estaba dispuesto a adherirse a las disposiciones de la ley islámica, a preservar los fondos públicos, a fortalecer el país, a lidiar con ataques extranjeros — se enfrentó a la flota danesay a establecer una relación de cooperación con los países islámicos y sus vecinos inmediatos. Véase Yahya Bouaziz y Míkel de Epalza, Le nouveau sur les relations de l'Emir Abdelkader avec l'Espagne et ses gouverneurs militaires a Mélilla, Constantina, Dār al-Ba't, 1982, y la edición de la correspondencia hispano-argelina del Archivo Histórico Nacional realizada por Yahya Bouaziz, Argel, 1993. 
la región, debido a su ubicación geoestratégica, su densidad de población, su riqueza cultural y económica, la fuerza de su flota naval y la estabilidad de su sistema de gobierno, especialmente durante el mandato del dey Muḥammad bin 'Uțmān. Figura fuerte, equilibrada y robusta, Argel llega al apogeo de su poder durante su mandato. Fue él también una de las figuras que apostó por la reconciliación y la paz con los países de la cuenca mediterránea.

Otra figura fundamental que contribuyó a la reconciliación entre Argelia y España fue Ḥasān wakil al-jāriy - título del comandante de la marina y relaciones exteriores-, cuyo barco fue capturado por España cuando regresaba de visitar al sultán otomano. Cuando los españoles conocieron a Ḥasān, el segundo hombre en importancia de la Regencia después del dey Muhammad bin 'Uțmān, decidieron explotar su posición para influir en el dey con el fin de aceptar la reconciliación. Aḥmad al-Šarîf al-Zahār, en su explicación sobre los motivos que motivaron la reconciliación entre Argelia y España, señala:

Ḥasān wakīl al-jāriŷ, mencionado anteriormente, fue enviado por Muhammad Pacha con regalos para su majestad el Sultán en Estambul. En el camino le siguieron algunos de los barcos de los españoles, y finalmente los cristianos le abordaron. Hablaron con él para mediar por ellos con el fin de concertar paces. Dicen que le regalaron una imagen adornada con lana y joyas, y con piedras preciosas. Cuando regresó Huasān Wakīl al-Jāriŷ de Estambul, se dirigió a maulana Pacha para referirle el asunto de la paz, diciendo que no se reconciliaría mientras siguiera vivo y permaneciera como jefe del Estado. De modo que los españoles llegaron por tercera vez y firmaron el rescate con dirhams. Y sucedió lo que se ha mencionado anteriormente, el bombardeo de la casa del emir y traslado del príncipe a la Casba, y todo esto con la intención de influir en ellos para aceptar la reconciliación, y así fue el caso ${ }^{3}$.

En general la historia de Zahār está cercana a la verdad, pues sabemos a través de otras fuentes históricas que Ḥasān wakìl al-jārîy tuvo relaciones muy estrechas con el rey de España y su primer ministro y algunos

3 Diario de al-Hâjj Aḥmad al-Šarīf al-Zahār Mudakarāt al-Hājj Ahmad al-Šarīfal-Zahār naqūb

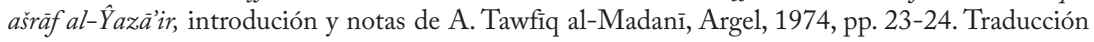
nuestra. 
políticos españoles. Su correspondencia con ellos fue intensa, tanto siendo ministro como convertido en dey de la Regencia después de la muerte de Muḥammad bin 'Uțmān. Expresó y presentó sus buenos sentimientos y sus respetos hacia ellos y lo trataron bien cuando fue capturado por los españoles, especialmente por Alejandro Baselini. En una de sus cartas, solicitó al gobierno español que honrara a Baselini y le asignara un trabajo importante. Floridablanca le respondió y Baselini fue designado para un alto cargo. Posteriormente y en carta fechada el 23 de febrero de 1787 , Hasān da las gracias por la amabilidad institucional para con su amigo, y promete reforzar las relaciones y liberar a los cautivos españoles en la Regencia. Hasān fue de este modo protagonista decisivo en la firma del tratado de paz entre Argel y el Reino de España. En efecto, entre I780 y 1798 envió un total de treinta y ocho cartas al rey español y su primer ministro, de las cuales diecisiete como ministro de emigración y veintiuna como dey. A través de las mismas se revela la buena disposición y esfuerzo por obtener relaciones privilegiadas y amistosas con España.

\section{Negociaciones de PAZ}

A través de la correspondencia del dey Muḥammad bin 'Uțmān Pacha y los políticos españoles, puede desprenderse la actitud a favor de un escenario de paz en la ribera occidental del mediterráneo, actitud plasmada a través de la labor de Hasān wakìl al-jārîy. Se supo enfrentar sabiamente a los problemas, en su lucha con el comercio marítimo y el corsarismo en general, así como con el aumento de los intereses de las potencias europeas. Se interesó así por la fortificación de la ciudad de Argel y el fortalecimiento de la flota naval. El incremento del poder naval europeo y las numerosas campañas que desgastaban la capacidad de resistencia de la ciudad de Argel, condujeron a la búsqueda de la paz y la seguridad regional e internacional.

Para firmar el tratado de paz con Argelia fueron enviados dos representantes de España, don José de Mazarredo y al conde de Expilly. E1 acuerdo fue firmado el I4 de junio de 1785 , en virtud del cual España se comprometió a entregar Orán y Mazalquivir ${ }^{4}$. Sin embargo, el acuerdo

4 Véanse detalles en Javier Sabater Galindo, "E1 Tratado de Paz Hispano-Argelino de 1786”, 
no fue inicialmente aplicado. Después de varios ataques entre los dos países, la paz se ratificó el I2 de julio de I79ı bajo la dirección del dey Husayn Pacha.

Entre otras disposiciones, esta paz se concluyó de acuerdo con las siguientes condiciones:

- España se retiraría incondicionalmente de Orán y Mazalquivir.

- España debía pagar anualmente al tesoro argelino 120 mil francos, correspondientes a 240 dinares argelinos.

- España devolvía a Argel todas las bombas, armas y municiones, que se recuperaron cuando se cedió Orán y Mazalquivir.

- Los barcos españoles llevarían oficialmente dos llaves de oro a Estambul, como símbolo de devolución de Orán y Mazalquivir.

Por su parte la Regecia de Argel se forzaba a aceptar los puntos siguientes:

- España debería tener una embajada comercial en la ciudad de Argel.

- Argel debía comprar tres mil kilos de trigo al año.

El acuerdo se firmó el 9 de diciembre de r79r y su aplicación final fue efectiva desde el I9 de diciembre de I79r. Las relaciones hispano-argelinas se encauzaron, a través de los varios tratados y relaciones comerciales dieciochescos, hacia una normalidad institucional que había sido imposible en los siglos precedentes 5 .

Cuaderno de Historia Moderna y Contemporánea, Universidad Complutense de Madrid, 1984, vol. 5, pp. 57-82.

5 Siguen siendo de consulta obligada los trabajos de Míkel de Epalza para evaluar en su justa medida las consecuencias de estas acciones políticas: "Algunas consecuencias del Tratado de Paz hispano-argelino de 1786", Homenaje a Guillermo Guastavino: miscelánea de estudios en el año de su jubilación como Director de la Biblioteca Nacional, Madrid, Asociación Nacional de Bibliotecarios, Archiveros y Arqueólogos, 1974, pp. 443-460; e "Intereses árabes e intereses españoles en las paces hispano-musulmanas del siglo XVIII", Anales de Historia Contemporánea, Murcia: ed. Universidad de Murcia, 1982, núm. 1, pp. 7-17. 



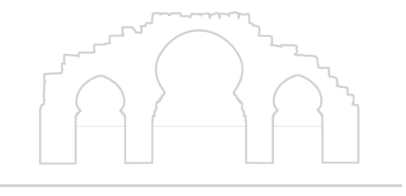

Artículos y Notas 



\title{
ANÁLISIS CRÍTICO SOBRE EL NAFH AL-TİB MIN- GUSTN AL-ANDALUS AL-RATIIB DE AL-MAQQARI
}

\author{
Mourad Kacimi \\ Universidad de Murcia
}

\begin{abstract}
Resumen
El presente artículo aporta datos sobre la personalidad del literato e historiador Ahmad al-Maqqarī y resalta el carácter enciclopédico de su obra Nafh al-țīb min-guṣn al-Andalus $a l-r a t ̦ i \bar{b}$ wa-dikr wazìiri-hā Lisān al-Dìn ibn al-Jațīb, y su importancia como fuente de transmisión de diferentes disciplinas en el campo de literatura de al-Andalus, reflejada en las numerosas biografías que recoge. Se describe la historia textual de sus ediciones y su fortuna literaria, junto a un análisis crítico de la vida del autor y el contenido de la obra.
\end{abstract}

Palabras clave: al-Maqqarī, literatura, al-Andalus, Naf̣̣ al-țīb, Ibn al-Jaṭîb, Tremecén y Fez.

\section{INTRODUCCIÓN}

Aḥmad al-Maqqarī fue un erudito del siglo XVII nacido en Tremecén. Su formación a lo largo del norte de África le capacitó para ser un notable literato e historiador. Es el autor de una importante obra de carácter enciclopédico titulada Nafh al-țīb min guṣn al-Andalus al-rațīb wa dikr wazìri-hà Lisān al-Dìn ibn al-Jațīb. Debido a la enorme cantidad de datos y la variedad de las disciplinas de las que trata, se considera ésta fuente imprescindible para cualquier investigación sobre al-Andalus.

El Nafh al-țīb, en su carácter literario, es una importante referencia bibliográfica que atrae tanto a investigadores sobre la poesía de al-Andalus como a los que se dedican a la literatura de viajes. De igual modo, es una obra de interés para los estudiosos sobre la historia de al-Andalus por los considerables datos que recopila. Se considera igualmente a Ahmad al-Maqqarī autor viajero como Ibn Jaldūn o Ibn Bațūța, por lo cual los investigadores sobre la literatura árabe de viajes estudian su personalidad y sus obras para analizar los datos que recoge sobre los distintos países que visitó. 
Estudiar la biografía de Aḥmad al-Maqqarī nos va a ayudar a entender la ideología de su época y tener una perspectiva general sobre el carácter de su obra $N a f h$ al-țîb, para luego hacer un análisis y realizar un breve estudio sobre la misma.

\section{Biografía de Ahmad al-Magqarī}

Su nombre completo es Aḥmad ibn Muḥammad ibn Ạ̣mad ibn Yahyà al-Qurašì al-Tỉimsānī al-Fāsī al-Mālikī al-Ašarīi, al-Maqqarī, de kunya Abū-1-'Abbās y de laqab Šihāb al-Dīn ${ }^{1}$, conocido también como al-Maqrīin (su nombre sigue siendo objeto de debate entre los investigadores) $)^{3}$. Entendemos que el único objeto de esta controversia es precisar la pronunciación del nombre del lugar de origen, aunque el debate surge no debido a él, sino a su antepasado, también reconocido escritor. Ibn Marzūq señala que la pronunciación exacta es la que corresponde a la alquería en donde nació su primer antepasado (primer sabio conocido

1 Véase su biografía en: É. Lévi-Provençal, “1-Makkarī”, $E I^{2}$, vol. VI, pp. 170-172; Šihāb alDīn al-Jafâŷ̀̄, Rayhạnat al-albā', El Cairo, 1878, p. 293; al-Muhibbī, Julāṣat al-atar, Beirut, pp. 302-312; Muḥammad ibn al-Ṭayyib al-Qādirī, Našr al-matānī, Rabat, 1978, p. 211; 'Abd al-Hayy al-Kattānī, Fihras al-fahāris wal-l-ițbāt wa mu ŷyam al-máâŷ̀im wa-l-mašyajāt al-musalsalāt, ed. Iḥsān 'Abbās, Beirut, Dār al-Garb al-Islāmī, 1982, vol. I, pp. 574-578; Muḥammad al-Ḥāŷŷ̀, al-Zawiyya al-dilāiyya, Rabat, al-Mațba'a al-Wațaniyya, 1964, pp. 108-113; “Mu'ŷam mašāhīr al-magāriba”,

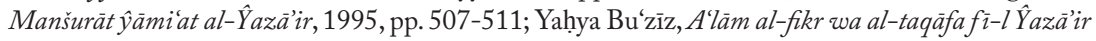
al-mahrūsa, Beirut, 1995, vol. II, pp. 166-166-179; Ibn Ibrāhīm al-'Abbās, al-I'lām bi-man ḥalla Marrakuš wa Agmāt min al-a lām, Rabat, al-Maṭba'a al-Malakiyya, 1974, vol. II, p. 308; Claudio Sánchez Albornoz, En torno a los orígenes del Feudalismo, Buenos Aires, 1977, vol. II, pp. 272-274; Ángel González Palencia, Historia de la literatura arábigo española, Barcelona, 1928, p. 193, Francisco Pons Boigues, Ensayo bio-biográfico sobre los historiadores y geógrafos arábigo-españoles, Frankfurt, 1993, pp. 417-419; 'Alī Ibn Ma'ṣūm, Sulāfat al-'asr fī mahāsin aššsu'ara'bi-kull miṣrr, Qatar, 1963, pp. 589-599; 'Umar Farrūj, Ma'álim al-adab al-'arabì, Beirut, 1985, vol. II, pp. 433-448; Manșūr 'Abd al-Wahāb, Introducción de Rawdat al-ās; Ahmad al-Maqqarī, Nafḥ al-țīb min guṣn al-Andalus ar-rațīb wa di ikr wazīiri-hā Lisān al-Dīn Ibn al-Jatì̄b, Beirut, Dār al-Șādir, 1988, vol. I, pp.1-13, 104-105, vol. II, pp. 282, 412, 419-421-423, 430-432, 436, 439-441, 446, 476-478, 480-482, vol. VII, p. 517.

$2 \mathrm{Ha}$ existido históricamente controversia en torno a su nombre. Los que afirman que es al-Maqrī son: Yāqūt al-Ḥamāwī, Muŷam al-buldān, Beirut, 1990, vol. V, p. 203; Muhammad al-Dahabī, al-Muśtabah fì al-riŷal asmā’ i-him wa ansābi-him, El Cairo, 1962, p. 609; 'Abd al-Qādir Zamāma, “al-Maqrī, al-Maqqarī”, Maŷāllāt Maŷma' al-luga al-'arabiyya, Damasco, 1971, pp. 99-104; Aḥmad Ibn Muḥammad Ibn al-Qāḍī, Durrat al-hị̂al fì asmä’ al-rîỹal, Túnez, 1972, II, p. 43. Los que afirman que es al-Maqqarī son la mayoría de los posteriores y los occidentales, como Aḥmad al-Tunbuktī, Nayl al-ibtihāŷ, Trípoli, 1989, p. 26; al-Muhibbī, Julāsat al-atar, p. 311.

3 Por ejemplo Multaqà al-dawlī: iā'dat qira'at turāt al-Maqqarī, Ŷamī'at al-Msīla, 03-05/03/2008. 
de dicho nombre al-Maqrī, procedente de Maqra) ${ }^{4}$. Así lo menciona en el libro Šarh al-alfyya, escribiendo al mismo tiempo una obra sobre la biografía de este antepasado titulada al-Nür al-badrí,fí-l-tárî́fbi-l-faqīh al-Maqri ${ }^{5}$. Pero la mayoría afirma que la pronunciación correcta de la alquería es Maqqara, al menos así se ha ido consolidando a lo largo de la historia.

En consecuencia, al-Maqqarī fue la forma conocida entre la gente de letras. Maqra es una alquería del sureste de Argelia, cuyo nombre está relacionado con este lugar. Sin embargo, ésta no se encuentra alrededor de Tremecén sino a treinta kilómetros de la ciudad de al-Muhammadia hacia el este. Hoy en día se la conoce como al-Msila, situada al este de Argelia, y continúa pronunciándose Maqra.

\section{Familia}

Su origen es qurayšż. Su familia procedía de la península árabe, así lo menciona el propio Ahmad al-Maqqarī en su Nafh al-țìb tomando como referencia la Ihata de Ibn al-Jațîb, quién recogió a su maestro, el abuelo de Aḥmad al-Maqqarī ${ }^{-6}$. Abū al-Fạ̣l al-Tilimsānī confirma este dato en un comentario sobre la anotación de un marroquí en el margen de la Thăta. Al-Maqqarī señala la mención de Ibn Jaldūn en su historia, y las de Ibn al-Aḥmar en su obra Națr al-ŷumān, al-Šayj Ibn al-Gāzī, Sìdī Aḥmad Zarūq, Aḥmad al-Wanšarīīi y otros. No obstante, para él, el testimonio de Ibn al-Jațīb es suficiente ${ }^{7}$.

Además del origen quray̌š̃ la familia de al-Maqqarī alcanzó un gran prestigio social, y mucha riqueza. Todo se fue perdiendo con los vaivenes sufridos en el Magreb, hasta que el abuelo de al-Maqqarī, Abū 'Abd Allāh Muhammad, logró de nuevo estabilidad para la familia. De esta riqueza, quedó una gran biblioteca de libros de los cuales se benefició nuestro autor ${ }^{8}$.

4 Es el šayj Abū 'Abd Allāh, Muḥammad ibn Aḥmad ibn Marzūq nacido en Tremecén entre 1310-1311, escribió muchas obras de historia, sufismo, religión y biografías. Era maestro de Ibn al-Jațīb en la escuela de Yūsuf I en Granada en 1353, murió en El Cairo en 1379.

5 Aḥmad al-Maqqarī, Nafḥ al-țîb, vol. V, pp. 204-205.

6 Véase Ibn al-Jațīb, al-Iḥạta fì ajbār Garnāṭ, Beirut, Dār al-Kutub al-Ilmiyya, 2003, vol. II, p. 116.

7 Naf̣h al-țīb, vol. V, p. 204.

8 Aḥmad al-Maqqarī, Naf̣ al-ṭ̂̀, vol. V, pp 205-206; Muhammad Ḥasān 'Abd al-Ganī, al-Ma- 
Su abuelo, Abū 'Abd Allāh Muḥammad, jugó un gran papel en el ambiente científico del Magreb. Fue reconocido en las obras de los historiadores, y se le dedicaron tres libros a su biografía: al-Nür al-badrī $f \bar{i}$ ta' rîf bi-l-Maqqarī, escrito por Abū 'Abd Allāh Ibn Marzūq; el libro de Abū al-'Abbās al-Wanšarīīì sobre al-Maqqarī, y otro titulado al-Zahr al-bāsim de un erudito marroquí'.

Por su parte, su nieto Aḥmad al-Maqqarī, en el quinto volumen del Nafh al-tīb le dedica una gran biografía recogiéndola de la Ihạta $a^{10}$, Nayl al-Ibtibāj ${ }^{11}$, e Ibn Jaldūn ${ }^{12}$. Al mismo tiempo recoge también las biografías de los maestros de su abuelo. De estos maestros resalta a Abū Hayyān el granadino ${ }^{13}$. En cuanto a los discípulos de su abuelo aporta interesantes datos sobre figuras importantes, como el visir Lisān al-Dīn ibn al-Jațīb, y el visir 'Abd Allāh ibn Zamrak, al-Qāệ̄ Muhammad ibn Saīd al-Șanhâŷì, Ibn Jaldūn, Abū Isḥāq al-Šațibī, 'Abd Allāh ibn Ŷuzayy al-Mufassir, y Muhammad ibn 'Ubād al-Rundī1' .

Por otro lado, el padre de Aḥmad al-Maqqarī no dejó ningún rastro en ningún campo del conocimiento. Nadie lo menciona al hablar de sus contemporáneos, incluso su propio hijo habla de su tío Sa'îd y no cita a su padre. Igualmente, no se sabe mucho de su madre, salvo lo encontrado en las tres cartas de pésame que recibió al-Maqqarī cuando murió su madre en $1629^{15}$, y en unos versos poéticos que mandó Ibn al-Labbāl para consolarle por la muerte de su madre ${ }^{16}$.

Aḥmad al-Maqqarī se casó dos veces. Su primera mujer era del Magreb occidental. Contrajo matrimonio cuando se estableció en Fez. Sin embargo, por la inestabilidad política, decidió fijar su residencia en Oriente. Al ver que no podía cumplir con sus obligaciones, le concedió el derecho de divorcio ${ }^{17}$. Con ella tuvo una hija que se quedó con la madre en

qqarī șāhib Naf̣̣ al-țìb, El Cairo, Dār al-Qawmiyya li-Ṭibā‘a wa-1-Našr, 1966, pp. 14-15.

9 Nafh al-țīb, vol. III, p. 174, vol. V, p. 204.

10 Ibid.,vol. V p. 203.

11 Ibid., vol. V, p. 289.

12 Ibid., vol. V, p. 254.

13 Ibid., vol. V, p. 253.

14 Ibid., vol. V, p. 340.

15 Ibid., vol. II, pp. 456-464-449.

16 Ibid., vol. IV, p. 232.

17 Muḥammad ibn 'Abd al-Karīm, al-Maqqarī wa-kitābu-hu Naf̣̆ al-țīb, p. 95, basado en las 
Fez. Sabemos de la hija a través de una carta fechada en el año IO4I/I63I enviada por el propio al-Maqqarī a su maestro al-Dalāî̀ desde El Cairo. Se sabe que le mandaba dinero, y pide a su maestro que la mantenga con la venta de sus libros en $\mathrm{Fez}^{18}$.

Su segunda mujer fue egipcia, de la familia de al-Wafäyyīn. Según parece, se casó con ella en 1029/1619-1620 tras su vuelta de Jerusalén, terminando este matrimonio también en divorcio. Tuvo con ella una hija que falleció en el año Io38/1628:9 ${ }^{19}$. Al-Šāhīnī envió una carta expresando su deseo de que Dios concediera a al-Maqqarī un hijo en compensación por la pérdida de su hija menor. La carta indica que al-Maqqarī no tuvo descendencia masculina ${ }^{20}$.

\section{Formación y viajes}

Al-Maqqarī nació en Tremecén en el año 986/1578 ${ }^{21}$, donde cursó sus primeros estudios de Corán y hadiz bajo la dirección de su tío alŠayj Abū 'Uțmān Sa'īd ibn Aḥmad al-Maqqarī̄2 . Fue en hadiz donde destacó, siendo más tarde célebre por sus conocimientos acerca de esta materia. También adquirió formación en literatura y derecho malikí en su ciudad natal.

Su primer viaje a Fez, en el año i6oo, fue recomendado por su tío para realizar estudios. Aprovechó esta estancia para visitar otras ciudades, como él mismo afirma. En I6or visitó Marrākuš, donde exploró las ruinas de la maqșūra de la mezquita, lugar en el que Ya'qūb al-Manșūr, de la dinastía almohade, había hecho su palacio. El mismo año visitó también

cartas de al-Maqqarī, ms. Rabat, número 471, pp. 47-53.

18 Ibid., pp. 223-224, basado en las cartas de al-Maqqarī, ms. Rabat, número 471, p. 530; Muḥammad al-Qādirī, Našr al-matānī, p. 298.

19 Al-Muhibbī, Julāṣat al-ạtar, vol. I, p. 302; Muḥammad al-Qādirī, Kitāb iltiquāt al-dūrar, p. 95.

20 Nafh al-țìb, vol. II, p. 466.

21 Algunos autores piensan que nació en 1000/1591, como Évariste Lévi-Provençal, Nujab tārījiyya, 1923, p. 93; Husayn Mu'nis, "Al-Maqqarī agrab safîr fī 1-wuŷūd", Maŷallāt al-'Arabī, núm. 52, 1963, p. 47. Otros autores opinan que al-Maqqarī nació en (990/1582 ó 992/1584) como Muhammad 'Inān, "Al-Maqqarī mu’arij al-Andalus", Maŷallāt al-Risāla, núm. 160, 1936, pp. 1210; Muḥammad Ibn 'Abd al-Karīm, al-Bustān fì di ikr al-awliyā' wa al-ulamä' bi-Tilimsān, pp. 214-219.

22 Véase su biografía en Aḥmad al-Maqqarī, Azhār al-riyāed fì ajbār al-Quạd̄ 'Iyād, Rabāt, 1978, vol. I, p. 494; Jayr al-Dīn al-Ziriklī, al-A'lām, El Cairo, 1954, vol. V, pp. 262-265; al-Kattānī, Fihras al-fahāris, vol. I, pp. 394-402; Muḥammad al-Kādirī, Našr al-matānī, p. 82; Aḥmad Ibn al-Qāạī, $\hat{Y}$ adwat al-iqtibās fì dikr man ḥalla min al-a làm madīnat Fās, Rabat, 1973, vol. II, pp. 519-520. 
la ciudad de Agmāt, y allí la tumba de al-Mu'tamid. En aquel momento Fez era un centro cultural de primera magnitud donde los magrebíes iban a completar su instrucción, sobre todo en el terreno de la teología. Regresó a Tremecén en r602. Volvió de nuevo a Fez en r6o4 con la intención de fijar su residencia. Allí continuó sus estudios, hizo numerosas lecturas de los textos de historiadores y literatos de al-Andalus, que luego le sirvieron de gran utilidad. Frecuentó los grandes sabios de la ciudad hasta que se convirtió en uno de los ulemas más destacados. De entre éstos cabe citar a Abū-1-Ḥasan, 'Alī ibn 'Abd al-Raḥmān ibn 'Umrān al-Salasī (960/ıoıI553/I6o9) 23, Abū 'Abd Allāh Muḥammad ibn Abī Bakr ibn Muḥammad al-Ṣanhāŷ̄ al-Dalā'ì (m.Io46/ı636) ${ }^{24}$, Abū-1-Qāsim ibn Muḥammad ibn Abū-1-Qāsim ibn Muḥammad Abū Na'īm al-Gassānīin, Abū 'Abd Allāh Muḥammad ibn Abū-1-Qāsim ibn 'Alī al-Qaysī, conocido con el nombre de al-Qașșār (m. IoI2/ı6o3) ${ }^{26}$, Abū-1-'Abbās Aḥmad ibn Abū-1-Qāsim al-Harawī, más conocido por al-Ṣawm²7, Abū-1-'Abbās Aḥmad ibn Muḥammad ibn Muḥammad ibn Aḥmad ibn 'Alī ibn 'Alī al-'Afiya alMaknāsī, conocido por el nombre de Ibn al-Qāệi (960/I553-Io25/ı6ı6)', Abū-1-'Abbās Aḥmad ibn Ạ̣mad al-Tumbuktī, más conocido por Aḥmad Bābā (963/I555-I032/ı623)29 y Abū Fāris 'Abd al-'Azīz ibn Muḥammad al-Qaštālī (956/I549-Io3I/ı62I ${ }^{30}$, Abū Muḥammad al-Ḥasan ibn Aḥmad ibn al-Ḥasan ibn Ya‘qūb ibn Muḥammad al-Masfîwī (m.Io32/I622) ${ }^{31}$.

En I027/ı6ı7, con el apoyo del sultán Zaydān al-Sa'dī, fue nombrado muftí llegando también a ser imán de la mezquita al-Qarawiyyīn. En el

23 Aḥmad al-Maqqarī, Rawdat al-'ās, al-'ațirāt al-anfās fī-dikr man laqìtu-hu min a' lām al-ḥadratayn Marrākuš wa-Fās, ed. 'Abd al-Wahāb Manșūr, Rabat, al-Mațbáa al-Malakiyya, 1983, pp. 332-335; Muḥammad al-Qādirī, Našr al-matānī, pp. 148.149.

24 Aḥmad al-Maqqarī, Azhār al-riyāẹ, vol. I, p. 494.

25 Aḥmad al-Maqqaīi, Rawdat al-'ás, pp. 315-316.

26 Nació en el año 939/1532 en Fez, fue muftí y predicador de Fez en el año 1010/1601, véase su biografia en Aḥmad al-Maqqarī, Rawựat al-ās, pp. 316-332; al-Kittānī, Fỉhras al-fahäris, vol. II, pp. 965-967; Muḥammad al-Qādirī, Našr al-mațāñ̄, p. 254; Naf̣̣ al-țīb, vol. VI, p.330; Ibn Ibrāhīm, al-I'lām, vol. V, pp. 208-217; al-Qādirī, Iltiqāt al-durar, Beirut, 1983, pp. 39-40; 'Umar Farrūj, A'àlim al-adab al-'arabì, vol. II, pp. 244-247.

27 Rawdat al-'ās, pp. 300-303.

28 Ibid., pp. 239-300.

29 Ibid., pp. 303-315.

30 Ibid., pp. pp. 112-163.

31 Nafth al-tî̀, vol. VI, p. 49. 
mismo año, tomó la decisión de abandonar el Magreb dirigiéndose hacia Oriente, a causa de sus relaciones con la tribu argelina de los širāga, ya que al iniciar el sultanato, Muḥammad al-Šayj al-Sa'dī había colaborado con 'Abd Allāh Ibn al-Šayj para usurpar el trono de Fez. Otra razón podría ser la envidia de los que no soportaban ver el rango de ese extranjero junto al sultán, que les conduciría a confabularse contra él y acusarlo de estar aliado con la mencionada tribu. Parece ser que la manera de relatar la historia trágica de Ibn al-Jațîb en el Naf̣̣ al-țîb, tiene que ver con su propia historia. En cualquier caso, esa acusación parece ser el motivo de su decisión de viajar a Oriente.

Al llegar al-Maqqarī a Oriente, ya era un hombre de mucho conocimiento, por lo tanto no señala que recibiera lecciones en estas regiones de muchos maestros, excepto de 'Abd al-Ra'ūf ibn Tāŷ al-'Ārifīn, conocido por Zam'u-1-Din al-Hadādī (952/I542-IO3I/ı6ı2) ${ }^{32}$.

El caos y el desorden que vivió el Magreb en su momento fue un motivo para que al-Maqqarī abandonara Fez. Dejó el Magreb en I6ı7 con la excusa de realizar el haŷyy a La Meca. Tras haberlo realizado, en el mes de raŷab del año I028/ı6ı8, se detuvo en El Cairo y allí se casó y fijó su residencia durante años. Pero su amor por los viajes no se paró, ya que visitó Jerusalén en $\mathrm{rabī}^{`} a l$-awwal de 1029/1619. Después de una estancia de ocho años en El Cairo volvió a visitar La Meca en I627, realizando este viaje hasta en cinco ocasiones.

Al-Maqqarī viajó a Damasco donde fue acogido generosamente por otros compatriotas magrebíes, y en donde enseñó en la escuela de Ŷaqmaq. Allí sostuvo importantes coloquios y justas poéticas, enseñando por la mañana el Șaḥịh de al-Bujārī. Todos los estudiantes y la mayor parte de los notables de Damasco acudían al mismo, siendo la lección de clausura de emoción general, empezando desde el alba hasta después del mediodía. Ningún otro sabio había recibido en Damasco reconocimiento tan general. Al-Maqqarī conservó este recuerdo el resto de su vida, y en su obra Naf̣ al-țib no deja de hablar elogiosamente de Damasco y de sus habitantes a la menor ocasión.

Dejó Damasco el 5 de šawwāl de I037/1627 dirigiéndose hacia El Cairo, pero volvió a fines de mes de $\check{s} a$ 'bàn de I040/ı630, y fue acogido 
con los mismos honores con los que había sido recibido la primera vez. A su vuelta a El Cairo, repudia a su mujer, y cuando se disponía a hacer el tercer viaje a Damasco para quedarse allí, le sorprendió la muerte en el mes de $\hat{y} u m a \bar{a} a \bar{~} I I$ en Io4I/I63I.

Nuestro autor tuvo discípulos tanto en el Magreb como en Oriente. De sus discípulos en el Magreb cabe mencionar a Abū-1-'Abbās Aḥ-

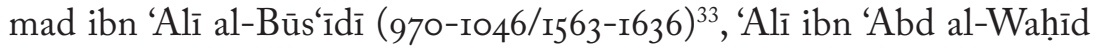

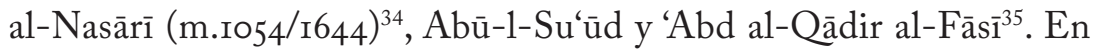
cuanto a Oriente podemos señalar a 'Abd al-Rahmān al-'Imādī al-Hanafīi ${ }^{36}$, Aḥmad al Šāhīnīīn, Yaḥyà al-Maḥāsīnī (m. Io53/ı643) ${ }^{38}$, Muḥammad ibn Yūsuf ibn Karīm al-Dimašqi ${ }^{-39}$, Muḥammad ibn Tāŷ al-Dīn ibn Aḥmad al-Maḥāsinī (Ior2/I6o3-Io72/I662) ${ }^{40}$, Muḥammad ibn 'Alī al-Qārīin , Al-Amīr Manŷak Ibn al-Amīr Muḥammad Ibn Manŷak (I003/I595-Io80/I669) 42 y 'Abd al-Bāqī al-Ḥanbalī al-Dìmašqī (Ioo5IO7I/I596-I66I $)^{43}$.

\section{Obras de Ahmad al-Maqqarī}

La obra más importante de Aḥmad al-Maqqarī es el Nafh al-țīb min

33 Al-Qādirī, Našr al-mațānī, pp. 356-362; al-Kattānī, Fahras al-fahāris, vol. I, p. 248; al-'Abbās ibn Ibrāhīm, al-I'lām, vol. II, pp. 314-316.

34 Al-Muhịbīi, Julāṣat al-ạtar, vol. II, pp. 380-389.

35 Ibid., vol. II, p. 467; al-Kattānī, Fahras al-fahāris, vol. I, pp. 763-771; al-Ziriklī, al-A'lām, vol. IV, p 166; 'Umar Rị̣ā Kaḥhāla, Mựam al-múalifìn, Damasco, Maṭba'at al-Taraqqī, 1957-1961, vol. V, p. 295.

36 Al-Būrīni, Tarāŷim al-a'yān min abnā' al-azmān, ed. Salāḥ ad-Dīn al-Munŷid, Damasco, Maṭba'at al-muŷama' al-'ilmī, 1959, vol. II, pp. 318-324; Naf̣̂ al-țîb, vol. I, p. 62; al-Muhạbbī, Julāṣat al-atar, vol. II, pp. 380-389.

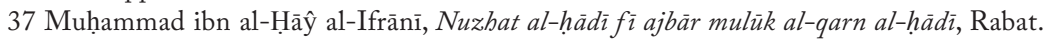
Maṭba'at al-țālib, [s.a.], pp.173-179. Al-Qādirī, Našr al-mațānī, pp. 107, 140-142.

38 Naf̣̣ al-țìb, vol. II, p. 430; al-Muhbbī,Julāṣat al-ạtar, vol. IV, p. 463; al-Ziriklī, al-A'lām, vol. IX, p. 187; Kaḥhāla, Mư̂yam al-mu'allifìn, vol. XIII, p. 184.

39 Nafh al-țīb, vol. II, p. 434; al-Muhibbī, Julāṣat al-atar, vol. IV, pp. 273-280.

40 Al-Muhibbī, Julāṣat al-ạtar, vol. III, pp. 408-411; al-Ziriklī, al-A'lām, vol. VI, p. 124; Kahhāla, Mu'̂yam al-mu'allifīn, vol. IX, p. 287.

41 Al-Muhibbī, Julāṣat al-ațar, vol. IV, pp. 154- 155.

42 Al-Ziriklī, al-A'làm, vol. VIII, p. 224; Farrūj 'Umar, Ma'álim al-adab al-'arabì, vol. II, pp. 701-707.

43 Al-Muhịbīi, Julāṣat al-ațar, vol. II, pp. 283-285; al-Ziriklīi, al-A`lām, vol. IV, p. 45; Kaḥhāla, Muŷam al-mu'allifin, vol. V, p. 72. 
guṣn al-Andalus al-rațīb wa dikr wazìiri-hā Lisān al-Dìn ibn al-Jațīb, sin embargo, tiene otras. El propio autor comenta en I037/1628, en dos versos poéticos, que escribió veintiocho tratados ${ }^{44}$. Este número aumentaría sin duda hasta la fecha de su muerte. En un trabajo anterior nosotros identificamos treinta y dos tratados ${ }^{45}$, y Muhammad 'Abd al-Karim le atribuye alrededor de cuarenta libros ${ }^{46}$. De los libros atribuidos a al-Maqqarī, Asmā’ al-Qāsimī afirma que dos obras le fueron atribuidas erróneamente, se trata de al-Ŷumān fī-ajbār al-zamān, y al-Durar al-mujtār min nawādir al-ajyār ${ }^{47}$.

En sus obras al-Maqqarī trató varias disciplinas. Tiene obras de carácter religioso sobre la 'aqīda (teología islámica) como I İààat al-duŷna bi-'aqā’id abl al-sunna ${ }^{48}$, y de šamā’il (descripción de las virtudes físicas del Profeta) como Fatḥ al-muta'āl fì madh al-ni'äl ${ }^{49}$, y Al-dur al-tamìn fì asmä' al-hādì al-amīn. Éste es un conjunto de poemas métricos que, pese a estar perdido, fue mencionado por al-Muhibbi y al-Yawāqīit ${ }^{50}$. En el campo de la historia y biografías tiene Rawdat al-'ās al-ațirāt al-anfās fì-dikr man laqītu-hu min a lām al-hadratayn Marrākuš wa-Fā̄s ${ }^{51}$, Azhār al-riyāẹ fì Ajbār al-qāẹ̄ ‘iyā $d^{52}$. En cuanto a Šarh muqaddimat Ibn Jaldūn, se trata de un texto perdido citado por Majlūf Muḥammad en Šâyarat al-nūr al-zakiyya fì-țabaqāt al-mālikiyya ${ }^{53}$. Tiene obras también sobre fiqh y fatwà (jurisprudencia y cuestiones jurídicas) como I'māl al-di $i h n$ wa-l-fikr fì-l-masā'il al-mutanawi'āt al-âynās ${ }^{54}$.

44 Nafth al-țīb,vol. II, p. 441.

45 Mourad Kacimi, "Abū-l-'Abbās Aḥmad Ibn Muḥammad al-Maqqarī al-Tilimsānī: su vida, formación y obras”, Revista Argelina, 2015, núm. 1, pp. 70-72.

46 Muhammad 'Abd al-Karīm, al-Maqqarī wa-kitābu-hu Naf̣̣ al-țìb, Beirut, Dār Maktabat al-Ḥayāt, 1990, p. 271.

47 Asmā’ al-Qāsimī al-Ḥasan̄̄, Rasā’il al-Maqqarī al-Tilimsānī: Dirāsa wa-tahqūq, Dār al-Jalīl li-1-Našr, 2009, p. 210.

48 Naf̣h al-tịb, la carta que recibió de Ibn Šāhīn, vol. II, p. 424.

49 Naf̣n al-țīb, la carta que recibió de Ibn Šāhīn, vol. II, p. 415.

50 Naf̣ al-țìb, vol. I, p.13.

51 Al-Ḥabīb al-Ŷanḥānī, p. 83; Naf̣̣ al-țìb, vol. V, p. 350, vol. VI, p. 59, vol. VII, p 81.

52 Ibid., p. 282.

53 Véase Muḥammad Majlūf, Šâyarat al-nūr al-zakiyya fì tabaqāt al-mālikiyya, vol. I, p. 303; al-Umhibbī, Julașat al-atarar, vol. I, p. 303.

54 Muḥammad ibn 'Abd al-Karīm, al-Maqqarī wa-kitābu-bu Nafh al-țīb, p. 280. 


\section{TRASCENDENCIA DE SU PERSONALIDAD CULTURAL}

Al-Maqqarī tuvo el cargo de muftí para promulgar fetuas en Fez desde el año I022/1613 hasta I027/1618, llegando a ser imán de la mezquita al-Qarawiyyīn de Fez. Se estableció en El Cairo al casarse con la hija de la familia de al-Wafā'iyyīn, que tenía gran prestigio. Destacó su valor como sabio por las clases que impartió en Ŷami al-Azhar durante su estancia en El Cairo; y que impartió también en al-Ŷāmi al-Aqșā en Jerusalén cuando la visitó por segunda vez. En Damasco fue acogido con gran reconocimiento, y a sus lecciones asistían todos los estudiantes y la mayor parte de los notables ${ }^{55}$.

Según su alumno 'Abd al-Bāqī al-Ḥanbalī, en ro28/I619 encontró a al-Maqqarī en Ŷami'al-Azhar impartiendo lecciones sobre $a l$-'aqìda, luego empezó a explicar el libro de al-Bujārī, "con una explicación maravillosa", y "era sabio en el hadiz y un gran literario". Dijeron otros alumnos suyos que al-Maqqarī relataba los seis libros del hadiz de la cadena de al-Qāạī 'Iyāẹ, y también relataba los libros de al-Šayj Zarūq, por la cadena de su tío, respecto a Muḥammad al-Jarūbī que los verbalizaba.

Describió Abū Salīm al-'Ayyāšī a al-Maqqarī en su libro $M \bar{a}^{\prime} a l-$ mawāìd como el hăffz del Magreb, y en al-Našr al-kabìr, de al-Qādirī, éste dice no conocer a nadie que tuviera más memoria que él, o supiera más hadiz. Dijo Abū-l-'Abbās al-Būs'îdī cuando menciona el viaje de al-Maqqarī hacia Oriente: "no quedó en el país nadie de su altura". Así mismo, dice al-Qāậi Ibn al-Hāâŷy en su libro Riyāẹ al-ward: "su obra Nafh al-țīb testifica su superioridad en el pensamiento y su conocimiento, es de los grandes sabios del Islam, afable, religioso, sabio y reflexivo" ${ }^{\text {"56. }}$

Tuvo al-Maqqarī gran valor con esta obra ya que no la escribió para enriquecerse o acercarse a los reyes y los emires, como era la costumbre de muchos sabios, sino que lo hizo por devolver una deuda y cumplir una promesa ${ }^{57}$.

55 Ibid., vol. I, pp. 57-69.

56 Naf̣h al-țìb, vol. VIII p. 6-7.

57 Ibid., vol. I, p. 111. 
IV. Descripción del NAFH AL-TịiB MIN-GUȘN AL-ANDALUS AL-RAṬīB

\section{Historia textual}

El nombre completo de la obra es: Nafh al-tìb min guṣn al-Andalus

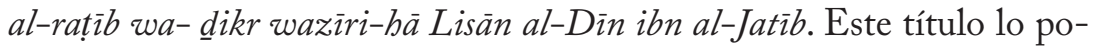
demos traducir por: Efluvio de perfumes sobre la memoria de al-Andalus y el recuerdo de su visir Lisān al-Dinn ibn al-Jatīb. El autor de la obra, en su larga introducción, comenta que al principio la nombró 'Urf al-țib, fì-l-ta'rîf bi-l-wazìr Ibn al-Jațibb pero, cuando le agregó las noticias de al-Andalus, le modificó el título ${ }^{58}$.

Esta obra fue editada por primera vez en Leiden entre los años I855I86r. La edición fue realizada por R. Dozy, G. Dugat, L. Krehl y W. Wrigt, pero se trataba de una edición incompleta; solamente incluía la primera parte de la obra en dos volúmenes bajo el título francés Analectes sur l'histoire et la littérature des arabes d'Espagne.

La segunda edición de E1 Cairo, en Bulāq, del año I862, fue editada por Muḥammad ibn 'Abd al-Raḥmān Qitța al-'Adawī en cuatro volúmenes. No tiene errores de imprenta pero está llena de tergiversaciones de los nombres andalusíes y magrebíes, y sin estudio introductorio ${ }^{59}$.

La tercera edición fue editada en El Cairo también, en la editorial al-Azhariyya en el año I886, con otros apéndices al margen del libro, en cuatro volúmenes bajo supervisión de Muhammad Qāsim al-Husayn ${ }^{-60}$.

La cuarta edición fue realizada por Aḥmad al-Rifā'ī y Aḥmad Yūsuf Naȳâtī en la editorial al-Ma'mūn en El Cairo, su primer volumen fue editado en 1936. Es la más precisa, aunque se trata de una edición incompleta.

La quinta edición es la de la editorial al-Sa‘āda en el año I949 en E1 Cairo, fue corregida por Muḥammad Muḥyī al-Dīn, pero sin criterios académicos.

La sexta edición contiene ochos volúmenes, fue realizada por Iṇsān 'Abbās, que corrigió los errores de las anteriores, y dedicó el octavo volumen a diversos índices. Fue editada en Beirut en el año I968 en la

58 Nafth al-țīb, vol. I, p. 70.

59 Véase 'Abd al-Salām ibn 'Abd al-Qādir Ibn Sūda, Dalīl mu'arrij al-Magrib al-aqșá, Casablanca, Dār al-Kitāb, 1960, vol. I, p. 231.

$60 \mathrm{Ibid}$. 
editorial Dār Șādir y reeditada otra vez en el año I997. Esta edición es con la que hemos trabajado.

Aun así, existe una última edición moderna realizada por Maryam Qāsim al-Ṭawīl y Yūsuf al-Ṭawīl en diez volúmenes y uno de índices, editada el año I998, en Beirut.

2. Fechas y circunstancias de la composición de la obra

Aḥmad al-Maqqarī nos comenta en su obra las razones que le llevaron a compilar esta obra. Estaba en Damasco repasando con algunos eruditos y literatos noticias de literatura e historia, y la conversación les llevó a hablar de al-Andalus, su hermosa descripción, su apasionada historia y sus magníficos sabios. Al-Maqqarī les expuso muchos relatos que tenía memorizados, lo cual les dejó asombrados. Al llegar a mencionar a Lisān al-Dīn ibn al-Jatîb, que jugó un gran papel en la historia de al-Andalus, destacó en sus cursos damascenos su valor político, científico, la poesía, las tertulias, sus maestros y sus obras. Habló de él de una manera maravillosa y admirable. En consecuencia, al-Mawlā Aḥmad ibn Šāhīn le recomendó escribir una obra sobre Lisān al-Dīn ibn al-Jatî̉ y los sabios y literatos de su tiempo ${ }^{61}$.

La lejanía de al-Maqqarī del Magreb y de sus libros y de las fuentes de origen andalusí, que eran escasas en Oriente, le dieron una buena excusa para disculpar hacerlo, pero la insistencia del literato y poeta damasceno Aḥmad ibn Šāhīn no le dejó otra opción más que aceptar, y le prometió empezar este proyecto en cuanto llegase a E1 Cairo ${ }^{62}$.

Nos dice al-Maqqarī que empezó a escribir su Nafḥ al-țîb cuando regresó a Egipto. Luego se cansó. Al enterarse al-Mawlā Aḥmad ibn Šāhīn, le escribió recordándole su promesa ${ }^{63}$, generando renovados esfuerzos de al-Maqqarī para cumplir y terminar el libro. Cuando al-Maqqarī le dio a Aḥmad ibn Šāhīn la noticia de la culminación del proyecto, éste se puso muy contento y le mando una carta felicitándole desde Damasco ${ }^{64}$.

61 Ibid.

62 Nafh al-țīb, vol. I, pp. 75-79- 80.

63 Ibib., vol. I, pp. 99-103-106.

64 Ibid., vol. I, p. 54. 
Por otro lado, la admiración de al-Maqqarī por Ibn al-Jațīb fue otro motivo para escribir un tratado sobre este personaje. De hecho, al-Maqqarī tuvo una historia similar a la de Ibn al-Jațīb, los dos ocuparon cargos políticos, los dos fueron traicionados en la corte y los dos estuvieron obligados a abandonar sus patrias. En fin, la obra también es un tributo a Damasco, ya que sus antepasados fueron los conquistadores de al-Andalus. Además, los damascenos que vivían en Granada la comparaban con su tierra natal, y al-Maqqarī se sentía en deuda por el buen trato recibido en Damasco ${ }^{65}$.

\section{Tipo de obra}

El Nafh al-tīb pertenece al género de obras de historia y biografías, pero también reúne aspectos literarios debido a la inmensa cantidad de poesía y prosa rimada que recoge. Su propio autor nos dice en la presentación de la obra que ha reunido en ella lo que es infrecuente juntar en otros libros ${ }^{66}$, y eso fue lo que dio a la obra sus características enciclopedias. Luego, al final del prefacio nos ofrece su descripción: "escribí una parte de la obra apreciada por los amantes, los oídos y los corazones, la ordené con la mejor metodología y expuse en su zoco cada objeto raro traído de Occidente a Oriente" ${ }^{67}$.

Al-Maqqarī perseguía una obra que reuniera una gran cantidad de datos sobre historia, literatura, poesía, biografías de personas notables y noticias, en su mayoría sobre al-Andalus, a la que pertenecía el visir, poeta y literato Ibn al-Jațib. Por consiguiente, la obra tiene dos objetivos: primero tratar sobre Ibn al-Jațib y segundo hablar de al-Andalus sus hombres y sus noticias, basándose en fuentes que mucha gente de conocimiento de su época no tuvo la oportunidad de leer, gran parte hoy desaparecidas.

4. Contenido de la obra

Al-Maqqarī dividió su obra en dos grandes partes: la primera parte (dos tercios del total) contiene una larga serie de fragmentos de autores

65 Ibid., vol. I, p. 117.

66 Ibid., vol. IV, p. 487.

67 Ibid., vol. I, p. 52. 
árabes sobre la historia política y literaria de al-Andalus. En el prefacio se encuentra su autobiografía, mitad en verso y mitad en prosa rimada, sembrada de versos locales, con motivo de sus diversas estancias en los países que cita.

La primera parte de la obra contiene ocho capítulos. Dedica el primer capítulo a la descripción física de al-Andalus, con citas de muchos geógrafos e historiadores, como Ibn Sa ${ }^{a} \bar{i} d$, Ibn Gālib, Ibn al-Jațî̀, Abū 'Amir al-Sālimī, Abū 'Ubayd al-Bakrī, al-Mas'ūdī, al-Ḥinŷārī, al-Šārīf al-Idrīsī, Ibn al-Nadīm, al-Rāzī, Ibn Jaldūn, al-Raqīq, Ibn Baškwāl, etc. Comienza al-Maqqarī con una corta digresión sobre el término al-Andalus, para seguir con comparaciones y descripciones de su superficie y fronteras, los habitantes anteriores de al-Andalus y las naciones vecinas, su clima y su riqueza. Luego menciona los diversos cargos del gobierno: los sistemas, el ministerio, el registro, el sistema financiero, el judicial, el sistema policial, la recaudación de impuestos, la vigilancia nocturna, los andalusíes y la legislación, su forma de vestir, su gestión y urbanidad, su interés por la religión, la filosofía, las ciencias, etc.

En el segundo capítulo habla de la conquista de la península ibérica por los musulmanes y las diversas narraciones sobre la conquista, los colonos árabes, gobernadores, relatos épicos de la conquista, origen de los conquistadores y las ciudades donde se asentaron, y los nombres de los gobernadores tras la conquista hasta el final de los omeyas.

En el tercer capítulo relata la historia de los califas y de los emires, historia de los omeyas, desde su instauración en el trono; las victorias, la tarea del $\hat{y} i \bar{h} \bar{d}$, y la fitna (la guerra y el desorden) los mulük al-țawä'if (los reyes de taifas), la intervención de los almorávides y los almohades, hasta los Banū al-Aḥmar de Granada.

El cuarto capítulo de la obra lo dedica a la descripción de Córdoba, su historia y monumentos. Da detalles sobre la construcción de Madinnat al-Zahrā', y Madīnat al-Zāhira. Incluye poetas y poesías descriptivas de todos ellos.

En el quinto capítulo recoge las biografías de los sabios andalusíes que se fueron a vivir a Oriente. Incluye trescientas siete biografías, en las que recoge sus nombres y da cuenta de sus actividades literarias. En el sexto, 
menciona las biografías de los sabios que vinieron de Oriente para vivir en al-Andalus, incluye ochenta y seis biografías.

En su séptimo capítulo describe a los andalusíes, su inteligencia, su interés en las ciencias, su talento y su voluntad. Y dedica el último capítulo de esta parte a la conquista de al-Andalus por los cristianos, los gritos de socorro en cartas de Ibn al-Jațîb a sus contemporáneos para salvarla, la descripción de las batallas y la caída de ciudades de al-Andalus.

En cambio, la segunda parte la dedicó enteramente al visir granadino. Esta segunda parte contiene también ocho capítulos. En el primero trata del linaje de Ibn al-Jațîb, sus orígenes y antepasados, indicando algunos poemas llamados al-Nūniya $t^{68}$. En el segundo, recoge su biografía de distintas fuentes en la que narran sus noticias y la envidia hacia él en la corte nazarí hasta su muerte. El tercero lo centra en los maestros de Ibn al-Jațîb, entre ellos el abuelo de nuestro autor, Muḥammad al-Maqqarī, a quien le dedica una extensa biografía. En el cuarto capítulo vuelve a tratar sobre la correspondencia diplomática de Ibn al-Jațīb con los reyes y algunas de las alabanzas que sus contemporáneos le dedicaron. En el quinto resalta su talento literario, sus poesías y su prosa rimada. En el sexto cita sus libros, como la Iṇạta, al-Lamḥa al-badriyya, y A'māl al-a'lām. El séptimo lo dedica a las biografías de los discípulos de Ibn al-Jațîb. En cuanto al último capítulo de esta segunda parte, lo reservó para hacer mención de sus hijos, su moral y los consejos que les dio.

\section{ANÁLISIS DEL NAFH AL-ȚİB MIN-GUȘN AL-ANDALUS AL-RAṬīB}

Al-Maqqarī, en su obra Nafh al-țîb, antes de dedicarse a la figura de Ibn al-Jaṭīb, consideró necesario resumir la historia de al-Andalus, por ser éste su país de origen. El libro se considera una enciclopedia por la variedad de los campos que trató, por lo que ha sido motivo de estudio por muchos investigadores tras la muerte de al-Maqqarī. Estos estudiosos, movidos por motivos religiosos o literarios, se han interesado por la obra y la inmensidad de su contenido.

A través de una lectura completa del Nafh al-țìb, nos llama la atención un tema muy repetitivo. Este tema no lo estudió al-Maqqarī directa- 
mente, sino que se resalta en su manera de narrar los hechos históricos relacionados con al-Andalus. Se destaca en su forma de ver las cosas, en su interpretación de la historia de la existencia de los andalusíes en la península ibérica. Nos describe el paraíso hecho por los musulmanes en la península, y nos presenta los motivos de su pérdida.

Sabiendo que al-Andalus fue conquistada por los reinos cristianos del norte, o reconquistada, al-Maqqarī quería transmitirnos la reacción de los andalusíes ante el empuje de los reinos cristianos. Esta guerra fue considerada "santa" por ambos bandos. Al-Maqqarī, en numerosas ocasiones, describe los actos militares reflejados en términos de $\hat{y} i \bar{a} \bar{d} \mathrm{y}$ de ribăt, a modo de defensa y como medio militar para recuperar lo que perteneció al territorio musulmán. Su tendencia religiosa está expresada en su descripción de las batallas, en sus deseos de recuperar al-Andalus, sobre todo, cuando narra la biografía de líderes musulmanes reconocidos por su esfuerzo en el $\hat{y} i \overline{\bar{a}} \bar{d}$. Estos deseos se resaltan en sus expresiones, cuando habla de la conquista de las ciudades, o los transmite directamente en textos de otros autores musulmanes que vivieron los acontecimientos de la conquista.

Llama la atención en la obra de al-Maqqarī el compromiso histórico, por la precisión del espacio relatado en relación a los hechos contemporáneos. Considera el naufragio de los andalusíes ruinoso en lo humano y lo cultural, a través del grito de socorro y petición de ayuda a los otomanos con un poema de más de cien versos mencionado en el Naf̣h al-țīb, y las circunstancias de la última emigración andalusí (I609-I6I4) hacia los países del Magreb. Lo cierto es que habían pasado pocos años desde la pérdida del reino nazarí, y los mudéjares eran forzados a convertirse al cristianismo. Al-Maqqarī vivió la expulsión de los últimos andalusíes, y no pasó mucho tiempo de la batalla de Wād al-Majāzin en la época del sultán al-Sa'dī.

Primero, al-Maqqarī nos describe el lugar, al-Andalus y el periodo que vivieron los musulmanes durante ocho siglos, centrándose en el siglo de la época de Ibn al-Jațîb. Hace de al-Andalus y su visir un punto básico sobre el que gira un círculo de conocimientos históricos y literarios conteniendo noticias de generaciones que pasaron por al-Andalus. Emplea fuentes históricas y literarias, como el libro de Ibn Jallikān, al-Ṣafadī, 'Abd al-Malik 
Ibn Ḥabīb, Ibn Ḥaŷar, Ibn al-Ațìr, y al-Zamajšarī, y algunos divanes de poetas, y aprovecha muchas fuentes andalusíes, magrebíes, y orientales. Dice al-Maqqarī que la mayoría de sus libros los dejó en el Magreb, y llevó con él unos pocos, lo que le obligó a contar más con su memoria. Pero la memoria le falla algunas veces, cayendo en muchas repeticiones. Realmente, lo que quería al-Maqqarī, a través de su estilo, era destacar las características del saber y de la literatura de los andalusíes. Se nota la influencia de la introducción de Ibn Bassām en su libro al-Dajīra ${ }^{69}$, también se nota la influencia del método de Ibn al-Jațîb en su libro alIhâta casi el mismo estilo de redacción en la parte de las biografías, pero al-Maqqarī se inclina más por la digresión que Ibn al-Jậ̣̂b. Él mismo lo menciona en su introducción ${ }^{70}$, justificando que un tema le lleva a otro.

Lo religioso también está presente en nuestro autor. Empieza su introducción dando las gracias al Señor de un modo espiritual, como si fuera un libro de religión. De vez en cuando utiliza expresiones del sagrado Corán.

Al-Maqqarī dio en el Nafh al-țîb mucha importancia a la descripción geográfica. Habla de las ciudades de al-Andalus y de sus habitantes, lo hace tras definir la etimología de al-Andalus, basándose en antiguos historiadores. Luego describe el clima del país, aclarando su superficie, sus fronteras, y sus primeros habitantes. En realidad, la ciudad es el escenario de los hechos históricos, de modo que hablar de la provincia es una introducción y complemento al propio contexto. Respecto a la descripción de al-Andalus menciona al-Maqqarī: "la belleza de al-Andalus no se define en una palabra, y su superioridad no se puede comparar" ${ }^{\text {"1 }}$. Mientras describe las ciudades, nos habla de su distancia, el espacio que las separa y su ambiente natural, montañas, ríos y clima. Menciona los pueblos pertenecientes a las provincias, da más importancia a los elementos de belleza que destacan cada ciudad, y finalmente expone la ruina de algunas ciudades y su desaparición ${ }^{72}$.

69 Ibn Bassām, al-Ḍajìra fì maḥāsin abl al-ŷazīra, Túnez, Dār al-'Arabīyya li-1-kitāb, 1975, pp. 14-16.

70 Nafh al-țīb, vol. I, p. 19.

71 Ibid., vol. I, p. 125.

72 Ibid., vol. I, p. 127 
Al-Maqqarī no sólo copia lo que otros escribieron acerca de la naturaleza de las ciudades, haciendo lo propio con sus misterios y sus maravillas, por ejemplo, las dos fuentes de Toledo ${ }^{73}$. Termina con una descripción geográfica breve de al-Andalus con un dicho del historiador Aḥmad al-Rā $\bar{i}^{74}$, dando sus distancias, el número de los ríos que tiene, de las ciudades grandes y las medianas, la gran cantidad de pueblos, fortalezas, fuentes, baños y minas ${ }^{75}$.

En lo que concierne a los habitantes de al-Andalus, al-Maqqarī les da mucha importancia, describe su carácter, su interés, sus talentos, y sus valores. Mientras habla de la ciencia dice que el que no tiene estudios aprende una profesión, y a nadie le gusta ser carga para los demás, y el sabio entre ellos tiene mucho valor ${ }^{76}$. Les describe como un pueblo desarrollado, les gustan las artes, aplican la religión ${ }^{77}$, su vida social es muy elevada, les gusta entretenerse recitando poesía, son generosos, y dan mucha importancia a la limpieza, se cuidan y visten bien, son buenos gestores, no derrochan. Se dividen las regiones de al-Andalus en tres: oriente, occidente y el centro. Habla en especial de Granada, Zaragoza, Toledo, Málaga, Lisboa, Valencia, Córdoba, Sevilla y Almería.

Aunque dedica el primer capítulo de la primera parte a hablar de la geografía y las ciudades, vuelve a hablar en el cuarto volumen de Córdoba, de Madīnat al-Zahrā’ y de Madīnat al-Zāhira detalladamente. Y en el séptimo capítulo pasa a describir la belleza y las características de algunas ciudades, recogiendo sus informaciones de la Risālat al-Š́$a q u n d \bar{\imath}^{-78}$. Además, cuando se ocupa de una ciudad, introduce un dicho de un historiador o un poema de un literato, luego vuelve a esta ciudad por segunda y tercera vez. Este esquema se repite en la mayoría de las ciudades de su libro.

73 Ibid., vol. I, p. 206.

74 Évariste Lévi-Provençal, "La «Description de l'Espagne" d’Aḥmad al-Rāzī. Essai de réconstitution de l'original arabe et traduction française", al-Andalus, 1953, núm. XLIII, pp. 51-108.

75 Nafth al-țīb, vol. I, p. 226.

76 Ibid., vol. I, p. 220.

77 Ibid.

78 A. Luya, “La Risāla d'aš-Šaqundī», Hespéris, 1936, núm. XXII, pp. 133-137; Emilio García Gómez, al-ŠSaqundī (Abū-l-Walìd Ismā̄ìl Ibn Muhammad). Elogio del Islam español (Risāla fĩ fạ̣l al-Andalus), Madrid-Granada, Escuela de Estudios Árabes de Madrid y Granada, Imp. Maestre, 1934, p. 123. Idem, Andalucía contra Berbería. Reedición de traducciones de Ben Hayyān, Šaqundì y Ben Al-Jațīb, Barcelona, Universidad de Barcelona, 1976, p. 164. 
Su descripción de los habitantes se encuentra dispersa a lo largo del libro, especialmente, en el primer capítulo de la primera parte, volviendo a ella, en el séptimo capítulo de la misma, para hablar de la superioridad de los andalusíes, de sus valores y de su buen comportamiento. Esta metodología le hizo caer en muchas repeticiones evidentes, a veces incluso con las mismas palabras ${ }^{79}$. Además, no habla detalladamente de los palacios, que son huellas destacadas, ya que sus restos permanecen hasta hoy en día.

La parte histórica la comienza indicando la importancia de la Historia. Detalla desde la conquista musulmana del mundo - no solo de la península ibérica一, luego la conquista de al-Andalus, pasando por sus sistemas políticos: la época del emirato, del califato omeya, los reyes de taifas, la intervención de los almorávides, los almohades y de los meriníes; las defensas, la civilización, los conflictos dentro del estado musulmán y en las fronteras contra los reinos cristianos del norte. Destaca por la precisión en las fechas de los acontecimientos más importantes.

En el plano literario, en la introducción del libro usa la poesía y la prosa rimada, tanto suya, como de otros autores para dar informaciones históricas. Y todo el libro lo llena de poesía y prosa rimada de personajes muy importantes en la historia de la literatura.

Al fijarse en el estilo del autor, en la obra se observa que registra siempre sus recuerdos, y que no mantiene un método concreto al copiar. Incluye en su libro muchas cartas de gran valor histórico, literario y político de personajes muy importantes, mencionándolas enteras, aunque sean largas. A veces, repite la misma historia o la misma información del mismo acontecimiento en más de un lugar, unas veces con más detalles, otras con un estilo diferente, y lo justifica diciendo que él sólo copia los dichos de los historiadores, aunque en ocasiones se contradigan unos con otros en algún pequeño detalle, con el motivo de dar más información ${ }^{80}$.

Se suelen considerar estas digresiones presentes en el Nafh al-tīb como una falta de método a la hora de realizar una clasificación de las materias, siendo éste en verdad un defecto común entre los autores árabes. No obstante, este defecto es quizá aún más aparente en al-Maqqarī, ya que se deja llevar por la narración y pierde constantemente su objetivo

79 Nafh al-țìb, vol. I, pp. 155, 462

80 Naf̣h al-țīb, vol. I, p. 290. 
principal. Otros, sin embargo, aprecian que este estilo es precisamente lo que da a la obra su carácter enciclopédico. Por eso, le llamaron el "Ŷāhị del Magreb" $"$.

Es cierto que la contribución personal de al-Maqqarī en esta obra es escasa. Salvo en el prefacio, no se encuentran aportes personales más que algunas frases, empleadas para unir los fragmentos o poesías recogidos. Digamos que, su modestia le llevó a presentar los dichos sin intervenir demasiado, o que sus escrúpulos científicos le impidieron relatar las noticias con su propio estilo sin indicar el auténtico autor. En realidad, su personalidad no desaparece en el libro; era un compilador y un escritor al mismo tiempo, copiaba todas las versiones de los historiadores indicando las diferencias de opinión y, a veces, dejaba que el lector las comparase ${ }^{82}$.

Muchas veces no se atreve a afirmar que la información sea cierta, empezando la noticia con: "dicen algunos" 83 . Otras veces apoya una versión sobre otra diciendo que lo que dijo el historiador tal es lo cierto, y lo que dijo el otro, no es verídico. Por ejemplo, cuando termina de hablar del sultán Ya'qūb al-Manșūr, escribe:

Murió el sultán Ya‘qūb en el año 595 y lo que se dice es que abandonó su cargo de sultán, se marchó de la tierra, llegó a Damasco, y fue enterrado en al-Biqā'. No es cierto, aunque Ibn Jallikān comentó algo de esto. Y el que afirmó su desacuerdo con esta noticia es al-Šarîf al-Garnāțī en $\check{S}_{a r h h}$ maqșürat Hāzim donde dijo: «Estos son dichos de la gente vulgar que quería mucho al mencionado sultán» ${ }^{84}$.

Y cuando trata del castigo de Mūsā ibn Nusayr, dice: "lo que mencionó Ibn Ḥayyān, que el califa Sulaymān ibn 'Abd al-Malik fue el que castigó a Mūsā ibn Nusayr es cierto, y lo que dijo Ibn Jallikān que fuera al-Walīd no es cierto y, ¡más sabe Dios!”85.

Cuando opina o apoya a uno sobre otro siempre añade: “iy más sabe Dios!"”6. Cuando sospecha de la veracidad de una información la expre-

81 Al-Muhibbīi, vol. I, p. 302.

82 Nafh al-țīb, vol. I, pp. 352-354-371.

83 Esto indica que por un lado se trata de un jabar o noticia oral, y por otro, que no es noticia que él pueda considerar segura y fiable.

84 Nafh al-țìb, vol. IV, pp. 382-383.

85 Ibid., vol. I, p. 273.

86 Ibid. 
sa por la palabra árabe za'ama que quiere decir que está confundido, y termina con: “iy más sabe Dios!” 87 . Frecuentemente, se emociona con la poesía de los poetas y ofrece de ella una breve interpretación ${ }^{88}$. E1 libro contiene centenares de títulos correspondientes a las fuentes de donde saca y copia el autor sus informaciones. Muchos de estos libros no se conservan en la actualidad o se encuentran desaparecidos.

Su metodología, a través del Naf̣ al-țīb, es una muestra representativa del estilo que usó en todas sus obras, donde suma todas las maneras de escribir. Se observa la gran cantidad de libros antiguos que conocía, así como la diversidad de las fuentes, contemporáneas y cercanas de su época. Consultó y leyó todos esos libros en su casa de Tremecén y en la biblioteca del sultán Zaydān de Fez, memorizando gran cantidad de textos gracias a su prodigiosa capacidad memorística. Cuando al-Maqqarī copia los poemas o las noticias, los copia enteros, sean cortos o largos, así que, a veces copia obras enteras casi con los mismos textos. De esta manera quiso hacer del Naf̣ al-țīb una recopilación de libros de otros autores. Ello se evidencia cuando, del libro al-Muhadarāt de su abuelo Abū 'Abd Allāh Muḥammad, que era juez supremo en Fez, copió once páginas ${ }^{89}$, y también copió, del mismo autor, ocho páginas de su libro al-Haqāiq wa-l-raqā’iq, y cuando terminó de copiar escribió: "se acabó lo que estaba relacionado con nuestro objetivo del libro al-Haqā’iq wal-raqā’iq de mi abuelo" 90 .

Se ha llegado a considerar al Naf̣ al-țib como copia de la obra al-Mugrib de Ibn $\mathrm{Sa}^{\prime} \overline{1} \mathrm{~d}$, sin mucho fundamento. Es verdad que recoge mucho de al-Mugrib pero también aprovechó de otras fuentes, porque el Naf̣ $a l-t \hat{\imath} b$ contiene noticias de la época de $\mathrm{Ibn} \mathrm{Sa}^{\top} \mathrm{i} \mathrm{d}$ y de periodos posteriores, como una gran fuente llena de noticias sobre al-Andalus y el Magreb, sobre todo en su última crisis. En fin, a pesar de las digresiones - que suponen una dificultad para el investigador interesado en buscar un tema concreto en esta enciclopedia-, al-Maqqarī preservó el legado andalusí del olvido, porque una gran parte de las fuentes que usó en su Nafḥ al-țîb

87 Ibid., vol. I, p. $277-278$.

88 Ibid., vol. I, p. 310.

89 Ibid., vol. III, pp. 148-159.

$90 \mathrm{Ibid}$. 
siguen todavía desaparecidas. Sabemos que al-Maqqarī copió mucho de al-Mugrib de Ibn Sa'îd, pero al comparar ambos textos se hace evidente que el autor tremecení se basó en una copia más amplia que la disponible hoy en día. También copió mucho de al-Muțmah, pero se basó sobre la versión amplia que no conocemos en la actualidad. Igualmente, sucede con otros libros que no existen hoy, tales como al-Ṭāli' al-sa'īd, Rawḍ al-riyāẹ, Ŷannat al-rị̣ā, y los libros de al-Maqqarī el abuelo, y al-Azhār al-mantūra, y otros que usó Aḥmad al-Maqqarī para esta composición. Este carácter enciclopédico que tiene el Nafḥ al-țîb, equivale a la consulta de docenas de libros.

\section{FORTUNA LITERARIA}

Debido a la importancia del Nafh al-țîb y el valor de su autor, la obra llamó el interés de numerosos estudiosos tanto en el mundo árabe como fuera, fue resumida por Ibn al-Wakīl, Abū-1-Haŷâŷ Yūsuf ibn Muhammad, que tituló su resumen Tagrìd al-Andalīb 'alā guṣn al-Andalus al-ratīib. La resumió a petición de un noble de El Cairo, lo estructuró en ocho capítulos y terminó su redacción en el año III4/I702. Este resumen se condensa en un gran tomo.

El segundo resumen lo hizo al-Ḥarīšì, Abū al-Ḥasan 'Alī ibn Aḥmad (m.II45/I723) en Medina. Su manuscrito se encuentra en la actualidad en Rabat ${ }^{91}$. La resumió también Hammūda ibn Muḥammad al-Nūrī en el año 1270/1854 ${ }^{92}$. Abū-1-'Abbās Aḥmad ibn Mụ̣ammad al-Rahūnī al-Tițānī lo tituló al-Lu'lu’ al-muṣì min naf̣ al-țîb y fue editado, la primera parte según Ibn Sūda, en el año I346/1927, pero no se acabó su edición ${ }^{93}$. Aḥmad ibn Dạ̣lān, en el año I304/1884 lo resumió y lo editó según Ibn Sūda ${ }^{94}$. Aḥmad al-Ŷazā’irī, lo resumió, y según al-Ŷanhān̄̄, hay una copia de este manuscrito en el Museo Británico ${ }^{95}$.

De igual modo, hallamos una traducción parcial de la obra realizada por Pascual de Gayangos, al inglés, en dos volúmenes, bajo el título:

91 Lo resumió porque no estaba de acuerdo con al-Maqqarī. Según él al-Maqqarī citaba muchas cosas que no concuerdan con la religión.

92 Al-Ŷanhānī, p. 77.

93 Ibn Sūda, Dalīl mưrrij al-Magreb al-aqșá, vol. I, p. 232.

94 Ibid.

95 Al-Ŷanhān̄ī, p. 478. 
History of Mohamedan dynasties in Spain, Extracted from Nafitu-t-tib min ghosni-l-Andalusi-r-rattíb wa táríkh lisánu-d-dín ibni-l-khattíb, publicada en Londres en los años I840-I843. Tuvo otra reimpresión en Nueva York en 1964. Se hizo una segunda edición, también en Londres, en el año 2002, en dos volúmenes. Gayangos sólo tradujo algunos pasajes relacionados con el reino de Granada. Fue duramente criticado por no haberla traducido entera, pero en el prólogo explica los motivos, como, por ejemplo, que Gallardo, el director de la Biblioteca Nacional, le negó rotundamente el permiso para trabajar en la Biblioteca de El Escorial.

En cuanto a los estudios, debido a la transcendencia cultural de al-Maqqarī, el valor y el carácter enciclopédico de su obra, ésta despertó el interés de investigadores de diferentes ramas del conocimiento. De entre los estudios realizados sobre la misma, cabe citar a al-Ŷanḥānī al-Habīib, autor de una obra muy interesante titulada al-Maqqari șābib nafh al-țīb; en la que habla de la biografía de al-Maqqarī, de su vida, sus viajes, etc., además, habla del autor como poeta, escritor, historiador y para finalizar nos da ejemplos de la producción literaria de al-Maqqarī. Su libro fue editado por la editorial al-Nahḍa, en Túnez, en el año I955.

La segunda obra fue realizada por Ibn 'Abd al-Karīm Muhammad, con el título de al-Maqqarī wa kitābu-hu Nafḥ al-țīb. Ésta trata, en la primera parte, de la época de al-Maqqarī desde un punto de vista político, social y cultural. Luego, habla sobre la personalidad del autor, su biografía, su familia, sus viajes, su producción literaria y dedica la segunda parte al análisis del contenido del Naf̣h al-țîb. Fue publicada en Beirut. 'Abd al-Ganī, Muhammad Hasan escribió una obra titulada al-Maqqarī șāhī $b$ Nafh al-țīb, publicada en El Cairo en la editorial Dār al-Qawmīyya li-1Ṭibā'a wa-1-Našr, en el año ı966. Al-Ka'āk 'Uțmān realizó también una obra que tituló al-Maqqarī, publicada en Túnez, en la editorial Mațba'at al-Šarika al-tūnisīyya. Bahmān Hudā Šawqat tituló su obra al-Nagd al-adabī fì-kitāb Naf̣̣ al-țîb li-l-Maqqarī, en ella habla de la biografía de al-Maqqarī y de aspectos de crítica literaria. Fue editada en Bagdad en el año 1978. 'Abd al-'Azīz, Aḥmad, recogió todos los datos relacionados con Egipto que aparecieron en Naf̣ al-tīib y los publicó en El Cairo bajo el título Miṣr fī Naf̣̣ al-țìb, en el año I986. Al-Andalus min Naf̣ al-țīb li-l-Maqqarī, fue el título elegido por 'Adnān Darwī̌s y Muḥammad 
al-Mișrī, que siguieron el mismo método de 'Abd al-'Azīz Aḥmad, fue editado este libro por Wizārat al-Taqāfa en Damasco en el año I99o.

De igual modo, la obra y su autor han sido objeto de diferentes tesis doctorales, como la de Celia del Moral Molina, titulada Los literatos granadinos en el Nafh al-țīb de al-Maqqarī, defendida en la Universidad de Granada en el año I982. Añadimos por último como ejemplo la tesis doctoral de al-Ewaidāt 'Alī con el título La poesía carcelaria y la cautividad en el Naf̣̆ de al-Maqqarī, defendida en la Universidad Complutense de Madrid el año 2005. 


\title{
MALTESES EN ARGELIA (1833-1900): ENTRE EL RECHAZO Y LA ACEPTACIÓN
}

\author{
DJAmel Latroch \\ Universidad de Mostaganem
}

\begin{abstract}
Resumen
Estudio histórico y estadístico de la presencia de población maltesa en Argelia durante el periodo de I833 a I900. A través del análisis de las fuentes históricas, se reconstruye cuantitativamente el volumen de la migración desde la isla de Malta a la Argelia de la primera colonización francesa, revelando la respuesta ambivalente tanto del gobierno colonial como de la población. Al mismo tiempo se explora lo que supuso la migración a Argelia en el contexto de la historia contemporánea de Malta como un destino predilecto por la vecindad geográfica y cultural.
\end{abstract}

Palabras clave: Malteses, Argelia, migración, política colonial, sociología.

\section{En homenaje a Juan Bautista Vilary Emilio Sola Castaño}

\section{Planteamiento inicial}

Las migraciones europeas hacia Argelia han gozado de numerosas publicaciones y aproximaciones por parte de historiadores interesados en precisar el papel de las diferentes comunidades extranjeras en territorios norteafricanos y su relación con la colonización francesa. En este sentido, la comunidad española en Argelia es una de las más privilegiadas al haber sido objeto de múltiples estudios, siendo el profesor Juan Bautista Vilar el pionero en estudiar todo lo referente a este proceso migratorio.

No obstante, las migraciones de origen mediterráneo no se limitaban exclusivamente a los españoles peninsulares. Los italianos, los mahoneses y los malteses, fueron efectivamente otras comunidades mediterráneas que se establecieron en Argelia bajo la colonización del siglo XIX. Estas comunidades tuvieron, de igual manera, su impacto, aunque de menor importancia, en la sociedad argelina, e incluso marcaron sus propios espacios geográficos diferenciándose entre ellas, como el caso de 
la presencia maltesa a lo largo de la franja mediterránea del este argelino. Esta comunidad no ha sido todavía objeto de estudios por parte de los investigadores, a pesar de su numerosidad y sus características especificas, salvo contados trabajos, como los de Ramiro Vadala en igı, Charles Price en 1954 y algunos trabajos del maltés Marc Donato, quien desde una perspectiva global la sitúa dentro de sus diferentes dimensiones tanto sociales como históricas, explicando las causas directas e indirectas y el modo de establecerse en tierras argelinas ${ }^{1}$.

Por otra parte, la presencia de estas diferentes comunidades mediterráneas no coincide con la política migratoria de las autoridades coloniales, sobre todo en la primera década, donde Francia no había precisado todavía cuál iba a ser su futuro en tierras africanas ${ }^{2}$. Sin embargo, a partir de 1847 se consolida la empresa colonial francesa y empieza con ella el control de la emigración. Cabe mencionar que la política migratoria francesa depende del país de procedencia del emigrante, y se caracterizó por dos facetas: la primera, la "oficial" destinada a los emigrantes europeos no mediterráneos, y la segunda, la "poco deseada”, reservada a la emigración mediterránea ${ }^{3}$.

Desde el comienzo de la colonización, las autoridades francesas establecieron el perfil ideal de los emigrantes que deseaban y esperaban: preferían suizos, belgas y alemanes, a los que les daban la bienvenida y les abrían todas las puertas para instalarse en suelo argelino ${ }^{4}$. Eran ricos, religiosos, leales y tranquilos, pero con desventaja en su inadaptación a la

1 Marc Donato, L'émigration maltaise en Algérie et Tunisie au XIXème siècle, Mémoire de DEA, Université Aix-Marseille, 1986. Idem, Elisa, la maltaise: histoire des maltais d'Algérie (1830-1920), Niza, Gandini, 2002; Lémigration des maltais en Algérie en XIXe siècle, Montpelier, Africa Nostra, 1985. Los profesores norteamericanos David P. y A. Smith también han estudiado la composición de la población europea, con mención particular a los malteses en el este argelino.

2 Yevette Katan, “Le voyage organisé des émigrants parisiens vers l'Algérie”, Emigration française: étude de cas: Algérie, Canada, Etat Unis, París, Publication de la Sorbonne, Série International, 1985, núm. 24, pp. 18-45.

3 Émile Temime, "La migration européenne en Algérie au XIXe siècle : migration organisée ou migration tolérée”, Monde arabe, migration et identité, Revue de l'Occident musulman et de la Méditerranée, 1987, vol. 43, p. 33.

4 Los alemanes eran los más deseados por las autoridades francesas. La propaganda y la publicidad oficial para captarles manifiesta la voluntad francesa para con "los deseados". Para acercarse a este punto véase Fabienne Fischer, Alsaciens et lorrains en Algérie: Histoire d'une migration (18301914), Niza, Jacques Gandini, 1999, p. 9 y ss. 
climatología norteafricana. En efecto, el informe de la comisión presidida por el general Bonet enviada a Argel en I833 concluye prefiriéndose a los alemanes y suizos como colonos más deseados: "les allemands et les suisses, qui vont au Nouveau-Monde chercher des terres incultes, se sont que nous devons le plus désirer de voir venir dans nos possessions d'Afrique" 5 . Por otra parte, los inmigrantes mediterráneos (españoles, italianos, mahoneses y malteses) se instalaron espontáneamente poco después de 1830 .

La emigración espontánea, de iniciativa personal, es una de las características del ciclo migratorio mediterráneo iniciado principalmente por españoles en la región de Orán y ciudades colindantes; a diferencia de los malteses, que preferían la región centro-oriental,instalados cerca a los puertos y en zonas muy cercanas a ellos. Puede confirmarse hasta cierto grado que la colonización de Argelia fue iniciada gracias al éxodo de la emigración europea en general y con mención particular a la mediterránea donde, efectivamente, las estadísticas oficiales de la época comprendida entre 1830 a 1847 dan crédito a ello.

\section{LOS INMIGRANTES MEDITERRÁNEOS EN LA POLÍTICA MIGRATORIA FRANCESA}

Desde el comienzo de la colonización Francia intentó, de manera sistemática, buscar cauces para controlar el desequilibrio demográfico entre los naturales del país y los europeos, temiendo la supremacía de argelinos sobre franceses, lo que podía poner en riesgo el futuro de la colonización. Para ello, se optó por permitir tolerándose la llegada de flujos migratorios mediterráneos encabezados por españoles, malteses e italianos para instalarse a lo largo del litoral argelino ${ }^{6}$. Sin embargo, los franceses ya residentes en Argelia quedaban a la espera de las decisiones de "la Metrópoli" de cara a la emigración al norte de África por falta de claras perspectivas en su política colonial y por la improvisación que mostraban. Cabe señalar que desde I833 hasta I847 fueron años muy duros para los colonos franceses que no pudieron resistir a la nueva vida y por

5 Procès-verbaux et rapports de la Commission nommée par le Roi le 7 juillet 1833, París, Imp. Royale, 1834, p. 92.

6 Kamel Kateb, Européens Indigènes et juifs en Algérie (1830-1962), París, Cahier N 145, INED, 2001, p. 28. 
consiguiente prefieren retornar a sus tierras natales: sobre 80.000 pasajes gratuitos otorgados a los franceses para desembarcar en Argelia en I837, 70.000 retornaban a su país de origen ${ }^{7}$. Y poco más tarde, entre 1842 a I846 se registró II8.000 salidas del total de i98.000 entradas.

A parte de estos problemas, hay otros que motivaron de manera directa el retorno de los colonos europeos: las malas cosechas sobre todo en la década 1858 -I867, provocando - a posteriori- una grave crisis alimenticia (hambre) entre I866 a I868 que provocó a su vez una repercusión mediática nacional e internacional ${ }^{8}$. Los fenómenos naturales (terremotos en I839, I846, I851, y las sequías) habían provocado de igual manera la salida de colonos y, al mismo tiempo, se demoró la llegada de otros interesados en instalarse en Argelia ${ }^{9}$. Efectivamente, Francia tuvo dificultades para implantar una comunidad puramente francesa en suelo argelino ${ }^{10}$, a causa del retorno masivo de los colonos europeos, y es que "la France (...) n'a guère réussi à implanter dans sa colonie d'Algérie un peuplement venu de la métropole. D'une certaine façon, ils étaient peu français, ces Européens d'Algérie qui se désignaient eux-mêmes au XIX siècle comme "Algériens" ou "Africains" et au XXe siècle comme "Européens"11.

Para recompensar la pasividad de los colonos a instalarse en Argelia, se toleró la llegada de inmigrantes del Mediterráneo que efectivamente, vinieron por oleadas, superando en ciertas regiones a los mismos franceses, como el caso de los españoles en el Oranesado. No obstante, poco después de 1836, Francia tuvo que pensar seriamente en controlarla y, por ello, se tomaron decisiones para su restricción. Paul Leroy recoge en su obra L'Algérie y la Tunisie la decisión ministerial que alertó del peligro y

7 Colonel de Ribourt, citado en Paul Leroy-Beaulieu, L'Algérie et la Tunisie, París, Librairie Guillaumin, 1887, p. 35.

8 Bertrand Taithe, "La famine de 1866-1868 : anatomie d'une catastrophe et construction médiatique d'un événement”, Revue d'Histoire du XIX siècle, 2010, núm. 41, pp. 113-127.

9 Abbé Burzet, Histoire des désastres de l'Algérie 1866, 1867, 1868, Argel, Imp. Centrale Algérienne, 1869, 34-44.

10 Desde 1830 Francia tuvo serios problemas para poblar Argelia. El rechazo de los franceses a instalarse en Argelia causó, efectivamente, insuficiencia poblacional, y casi toda la política colonial en la primera década fue un fracaso. Cf. Alain Lardillier, Le peuplement de l'Algérie de 1830 à 1900: les raisons de son échec, Versalles, Atlanthrope, 1992, p. 17 y ss.

11 Gilles Manceron y Hassan Remaoun, D'une rive à l'autre, La guerre de l'Algérie de la mémoire à l'histoire, París, Syros, p. 91. 
de la preocupación del gobierno francés para:

[...] d'arrêter une immigration trop nombreuse et trop hâtive, d'obvier au désagrément de voir tomber des individus dans la détresse pour s’être inconsidérément transportés dans cette contrée sans savoir les moyens d'y vivre et fixés et assurés», incluso propone medidas para frenarlo: «Le gouvernement français, outre les mesures déjà prises pour empêcher l'immigration spontanée de pénétrer en Algérie, a cru devoir en interdire l'accès dorénavant, jusqu'à nouvel ordre, à tout étranger qui ne pourra établir amplement qu'il a de quoi s'y entretenir ${ }^{12}$.

Coincidiendo con el resultado de la Comisión Bonet de i833, el abogado Eugène Lerminier en un artículo publicado en la prestigiosa revista Revue des Deux Monde (I836), pone de manifiesto la importancia de Argelia como única respuesta a todos los problemas económicos y sociales de la Francia de Louis-Philippe, incitando a todos los franceses a seguir adelante la colonización 'Le sol de l'Afrique est doué d'une grande fécondité qui provoque et récompense le travail. L'agriculture, dont la France a le goût et le génie, peut s'y déployer à l'aise"13. Y añade, dejando constancia del valor de Argelia para la seguridad interna y externa de Francia:

La possession du littoral de l'Afrique est nécessaire, non seulement à l'éclat, muais à la sûreté de notre empire. Nous avons besoin d'une position forte pour contrebalancer Gibraltar, canon toujours béant, toujours armé, et pour avoir dans la Méditerranée l'équivalent de Mahon, qu'un réveil et des inimitiés de l'Espagne pourraient un jour nous rendre formidable. Il importe à notre liberté et à notre commerce dans la Méditerranée de rester propriétaires d'un vaste territoire africain. Alger protège Marseille. Croit-on que les Anglais eussent incendié le port de Toulon si les flottes françaises eussent eu en Afrique d'autres rades et d'autres ports? ${ }^{14}$

12 Paul Leroy-Beaulieu, ob. cit., pp. 31-32. No obstante, por el decreto ley de 18 de septiembre de 1848, Francia intentó organizar la emigración de los franceses y al mismo tiempo intentar asimilar el fracaso continuo de la repoblación de Argelia de la década anterior. Mediante la propaganda y la publicidad, las autoridades francesas querían captar en su mayor parte franceses interesados en instalarse en Argelia. También los alemanes, a partir de 1850, fueron objeto de esta publicidad y propaganda mediante folletos distribuidos en las mismas tierras alemanas y artículos de prensa en periódicos locales en lengua alemana.

13 Eugène Lerminier, "De la colonisation d'Alger”, Revue des Deux Mondes, París, 1836, tom. 6-1, pp. 607-608.

$14 \mathrm{Ibid}$. 
Ahora bien, para igualar la poblacion francesa con el colectivo europeo, Francia permitió a partir de 1847 la instalación de todo tipo de emigrantes, cediendo el paso para que:

[...] arrivent des paysans des régions pauvres du sud-est de la France et de la Corse, des chômeurs des ateliers nationaux de 1848, des condamnés politiques de 1852 , des enfants trouvés, des forçats, des viticulteurs du Languedoc victimes du phylloxera, des Alsaciens-Lorrains de i87i fuyant l'Allemagne, des soldats démobilisés, des émigrants du bassin occidental de la Méditerranée qui échappent à des pays misérables et trop peuplés ${ }^{15}$.

Así pues, la política migratoria de las autoridades coloniales en Argelia dependió de las circunstancias económicas pero, sobre todo, de las políticas de la metrópoli ${ }^{16}$. Y por consiguiente, a partir de I87o, se mostró más favorable a la asimilación de las comunidades extranjeras bajo leyes de naturalización o de concesión de nacionalidad para aquellos mismos que, unos años antes, habían sido los menos deseados, tales como los malteses, italianos y españoles.

\section{Dinámica demográfica maltesa y mediterránea en Argelia}

Estadísticamente hablando, en I833 había I.2I3 malteses censados en toda Argelia, y tres años más tarde se calculan r.802 ${ }^{17}$. A finales de 1836 se sumaban 9.076 extranjeros de origen no francés residentes en Argelia, frente a 5.485 de franceses repartidos esencialmente en Argel, Orán y Bona. El número de malteses ocupaba la tercera escala con los ya señalados I.802, después de italianos (I.845) y españoles (4.592). En I846 se

15 Jean Ferniot, De Gaule et le 13 mai, París, Plon, 1965, p. 13.

16 Sessions Jeneffer, "Le paradoxe des émigrants indésirables pendant la monarchie de juillet, ou les origines de l'émigration assistée vers l'Algérie", Revue d'Histoire du XIXe siècle, 2010, núm. 41, pp. 63-80.

17 Todas las estadísticas que manejamos en este texto están sacadas de diferentes obras: Victor Demontès, Le peuple algérien. Essais de démographie algérienne, Argel, Imprimerie Algérienne, 1906; idem, "Études de démographie algérienne. Les populations européennes. Leur accroissement, leur densité et leurs origines", Revue des Questions Diplomatiques et Coloniales, París. 1900, tom. 10, pp. 193-211; Augustin Bernard, "La colonisation et le peuplement de l'Algérie d'après une enquête récente”, Annales de Géographie, 1907, tom. 16, núm. 88, pp. 320-336; Alain Lardillier, ob. cit.; René Ricoux, La démographie figurée de l'Algérie, París, Masson, 1880 ; e idem, La population européenne en Algérie pendant l'année 1884, Etude statistique, Philippeville, Feuille, 1885. 
contabilizan 8.858 , casi el $40 \%$ del total de los extranjeros censados son residentes en la zona del actual Skikda. En este año, se calcula que había unos ro9.380 europeos en suelo argelino, donde 47.247 son franceses (43\%), 31.528 son españoles (28\%), y el total de las comunidades extranjeras sobrepasa claramente a los franceses por I4.832 almas, es decir, el I4\% del total de la población extrajera en Argelia. En i847, se calcula que había un total de 8.788 unidades de origen maltés, donde 4.6Io vivían en Argel, ocupando la tercera categoría después de los españoles (3I.528) y de los franceses (47.274); y el total de europeos en toda Argelia es I03.610. ${ }^{18}$ Mientras se estima que son 7.307 personas en I85I.

Sin embargo en el censo de I856, I67.640 es el total de los extranjeros residentes en Argelia, donde el elemento francés sobrepasa a las demás comunidades europeas: 92.738 franceses frente a 66.544 de otras nacionalidades. Los malteses suman 7.II4. ${ }^{19}$ Estas cifras vienen desde 1847 en aumento gracias a las políticas migratorias y la empresa colonial de los franceses. En efecto, a partir de las estadísticas de I86i, en un total de 205.888 residentes europeos, había 80.5I7 extranjeros no franceses: españoles 48.I45, italianos II.8I5, malteses 9.378; frente a II2.229 de origen francés. Unos 245.II7 y 3II.462 de extranjeros europeos en los censos de 1872 y I876, donde los malteses censados ascienden a II.5I2 y I4.220 respectivamente, mientras los franceses son I29.60I para el primer año y I45.727 para el segundo.

Cabe mencionar que el factor de la natalidad entre estas comunidades europeas había hecho aumentar el número de los residentes en Argelia y, efectivamente, en el Departamento de Argel desde I830 a I853 se calculan unos 25.4II nacimientos, unos II.755 y 7.734 en los Departamentos de Orán y Constantina respectivamente. Entre i876, I877 y i878, en toda la geografía argelina, había 34.67 I nacimientos de europeos frente a

18 M. E. Carette, «Algérie», Univers ou histoire et description de tous les peuples, París, Firmin Didot, 1856, p. 41.

$19 \mathrm{El}$ doctor René Ricoux en su obra La démographie figurée de l'Algérie (1880) calcula que en el año 1856 había en el territorio argelino 92.750 franceses, 42.218 españoles, y 7.114 malteses, y el total de los europeos alcanzaba 169.186. Estos números son idénticos a los de la obra de Victor Demontés Le peuple algérien: essais de démographie algérienne (1906), salvo que el total de los europeos es de 160.798. también en las dos obras, la totalidad de la población europea en 1861 es idéntico. Réné Ricoux calcula que son 205.888, mientras Demontés estima que son 192.646. Esta inexactitud en los números nos pone siempre alerta al comparar los números. 
32.159 fallecimientos, es decir una diferencia positiva de 2.512; mientras los malteses en estos tres años se calculan en r.572 unidades. Entre los I4.220 malteses censados en I876, había 518 niños nacidos. Generalmente el número de la natalidad oscila entre 400 y 500 anualmente. En los I5.402 —el total de los malteses en I88I- se registraron 569 nacimientos. La estimación de la natalidad en el período comprendido entre I854 a I873 es de 3.695 personas. No obstante, en I884 había 504 nacimientos de padres malteses ( 285 chicos frente a 219 chicas); en este mismo año los niños nacidos de padres malteses y madres francesas son 24 hijos y con italianas 27 nacimientos, y el total de los nacimientos de malteses es de 578. Los nacimientos de los malteses en toda Argelia (I884) no supera ni la mitad de los nacimientos de los italianos que se calculan alrededor de I.279, ni tampoco a los nacimientos entre la comunidad española, que se calculan alrededor de 4.872 de matrimonios legales y de uniones ilegales; mientras en 1886 fueron 584 unidades (I5.333 total de malteses).

Por otra parte y en 1842 , se habían celebrado 84 enlaces matrimoniales entre malteses, mientras los españoles e italianos celebraron 592 y I50 respectivamente. Los matrimonios mixtos o cruzados, otra cara del aumento de la población en Argelia, no tuvieron números sorprendente entre franceses y las comunidades europeas. Desde I830 hasta I877 se celebraron en toda la geografía argelina 23.217 enlaces entre franceses (nacionales) y I4.568 entre extranjeros (franceses no incluidos). Entre franceses y mujeres de nacionalidad europea se calculan a 5.073 mientras entre francesas y extranjeros de sexo masculino (no francés) se calculan a I.808 enlaces matrimoniales, y el total de todos los matrimonios en este período es de 44.8I6, incluidas otras comunidades extranjeras y extranjeros casados con musulmanes y judíos.

En los años I879, I880 y i88I se celebraron 972 uniones entres franceses y mujeres de todo tipo de nacionalidades europeas, no obstante, en los años I882, I883 y I884 había I.I27 de matrimonios mixtos entres franceses y mujeres extranjeras, mientras entre éstas y hombres extranjeros se calculan a 403 uniones. En el bienio I882 a I884 se celebraron 3.43I enlaces matrimoniales entre extranjeros no franceses. Las maltesas eran las menos solicitadas por matrimonio con los franceses. En I884, según 
René Ricoux ${ }^{20}$, se registraron 28 matrimonios entre franceses y maltesas (5 en Argel, I7 en la región de Constantina y ninguno en el Departamento de Orán); mientras se celebraron 84 matrimonios de nacionalidad maltesa donde 39 se celebraron en Constantina. Sobre cien niños nacidos de padres franceses, en 1884, sólo 9 tienen madre maltesa, 62 de madre española y 19 de madre italiana. Los malteses, al contrario, prefieren contraer matrimonio con francesas debido a la situación en que vivían; sin embargo, 38 es el total de matrimonios cruzados entre malteses con mujeres europeas: II con francesas, el mismo número con italianas y I5 con españolas. Hay que recordarse que los malteses en Argelia como en su país de origen siempre tienen la media de cinco a seis hijos por matrimonio y si es de matrimonio cruzado la media es de dos hijos, y siempre se casan siendo muy jóvenes donde los esposos no sobrepasaban los veintiún años y las mujeres - generalmente- dieciocho años a la hora de contraer matrimonio.

La mortalidad maltesa en 1876 y 1886 fue de 373 y 479 unidades respectivamente, cifra bastante considerable en comparación a la totalidad de esta comunidad ${ }^{21}$. Desde 1830 hasta final del siglo XIX, el año más significativo fue el de I889 por la tasa de mortalidad más elevada: 704 frente a 514 de nacimientos. Mientras en 1884 hubo 397 fallecimientos ( 243 varones y I 45 de sexo femenino), es decir unos I 45 nacimientos por Ioo fallecimientos; mientras en I882 casi se igualan las cifras. A partir de 1894, 302 es el total de mortalidad maltesa en Argelia. En la década comprendida entre 1894-1903 se calcula que el total de la mortalidad era de 3.134 personas: I.842 de sexo masculino y r.322 de sexo femenino.

Natalidad por nacionalidad y por sexo en 1884

\begin{tabular}{|c|c|c|c|c|}
\hline Padre/madre & Maltesa & Española & Italiana & francesa \\
\hline Francés & 60 & 432 & 137 & 4.173 \\
\hline Español & 18 & 4.038 & 32 & 90 \\
\hline Italiano & 29 & 72 & 1.052 & 109 \\
\hline Maltés & 578 & 24 & 27 & 504 \\
\hline
\end{tabular}

Fuente: Ricoux René, La population européenne en Algérie pendant l'année 1884.

20 Véanse las tablas al final del texto.

21 Conviene recordarse que hubo muchas epidemias en Argelia y en la zona del Mediterráneo: cólera (1867), tifus y viruela (1868), filoxera (1885), cólera (1886). 
Estas cifras, aunque orientativas, nos sitúan dentro del recorrido panorámico de las diferentes comunidades europeas en Argelia y nos afirman la importancia de la emigración mediterránea en la colonización de Argelia. Los malteses, por otra parte, residen esencialmente en el este argelino, en localidades como Bona, Cala y Colo que son, entre otras ciudades centro-orientales, zonas preferidas por los recién llegados. Éstos instalados muy inmediatamente a partir de I830, aumentan de forma progresiva hasta 1896 (después de la Ley de Naturalización Automática de 1889 se consideraban ya franceses). Es digno de señalar que el auge de la presencia de malteses se sitúa entre I88I a I89I donde se había registrado su mayor número: 15.402 y I4.677 respectivamente ${ }^{22}$. En I886 había en Argelia un total de 15.533 malteses y en I89I y I896 había I4.677 y I2.8I5 unidades respectivamente: un descenso de r.862 unidades.

En suma, esta comunidad en comparación con las demás comunidades europeas - española sobre todo- fue relativamente modesta en sus cantidades. En I872, los malteses, en toda la región del este representan el 73\%, mientras en la región del centro (Argel) representan sólo el 26\% y en el Oranesado, sin embargo, no alcanza el uno por ciento ${ }^{23}$. Desde I85I hasta 1872 se habían ganado del elemento maltés más de 3000 almas. En la región de Bona en 1846, el 40\% de la población europea es de origen maltés. En Orán en I88I, se calcula que había 463 unidades, cifra muy inferior comparándola con los que habitaban Bona (actualmente Annaba). Mientras en 1886 , se había registrado el mayor número de esta comunidad en la región de Constantina, Io.8II. Sin embargo, en el centro argelino se estima que eran 4.I49 unidades y, como es lógico, en el Departamento de Orán no alcanzaban las 573 almas. Cabe mencionar que desde 1833 hasta 1850 la comunidad maltesa sobrepasaba claramente a la comunidad italiana en toda la geografía argelina: I.2I3 frente a I.I22 en el año I833; en r850 se igualan y los italianos se posicionan en las tercera escala justo después de la comunidad española y de los franceses. Mientras en I856 la comunidad italiana ganaba numéricamente a los malteses, que se calculan en 7.II4 frente a 9.472 de italianos, es decir una diferencia de $2.35^{8}$ almas.

22 Las cifras que manejamos aquí están recogidas de diferentes obras, libros, y artículos sobre este tema. Véanse las tablas al final de este texto.

23 Donato, ob. cit., 2012. p. 7. 
Matrimonios por nacionalidad y por sexo en I 884

\begin{tabular}{|c|c|}
\hline Padre & Maltesa \\
\hline Francés & 28 \\
\hline Español & 03 \\
\hline Italiano & 16 \\
\hline Maltés & 84 \\
\hline Alemán & 01 \\
\hline Otros & 01 \\
\hline
\end{tabular}

Fuente: Ricoux René, La population européenne en Algérie pendant l'année 1884.

El aumento de la comunidad maltesa se culminó en el año I886, cuando se registraron 15.333 unidades, ocupando la tercera categoría de población extrajera europea por encima de alemanes, belgas y suizos juntos. A partir de I887 empezó a descender perdiendo anualmente unidades: en 189I se perdió el total de I.656 con respecto al año r 886 y en el año i 896 se estima que había 13.986, es decir una pérdida de I.509 comparándola con el año I89I y diez años más tarde (I9OI) se calcula que la comunidad maltesa no superaba las 13.250 personas ${ }^{24}$. El total de los europeos, incluidos los naturalizados, se calcula en 364.257 , donde la mayoría eran españoles $155.265^{25}$.

La pérdida del elemento maltés fue debida a causa de las represalias legislativas contra todos los emigrantes mediterráneos y, al mismo tiempo, a los efectos de las diferentes leyes de naturalización, donde se consideraban franceses nada más naturalizarse. Por otro lado, a partir de I88I se dirigían al vecino Túnez, un protectorado francés que no se les exigía mucho sacrificio para adaptarse, aprovechando la cercanía geográfica y las pocas horas de travesía para llegar.

\section{Malteses en Argelia: entre el rechazo y la aceptación}

Si Argelia para los españoles es la tierra de promisión, para los malteses, no obstante, es el Dorado, país donde no faltaba de nada: trabajo, riqueza y placer, un país de "oro" donde se asegura un futuro mucho

24 Demontés, ob. cit., 1906, pp. 52-53.

25 Ibid., p. 26. 
mejor que en el país de origen. Para un maltés, Argelia no es aquel lejano país latinoamericano, fabuloso o imaginario sino, al contrario, una tierra cercana geográficamente donde se puede llegar fácilmente con la certeza de tener mejor condición de vida nada más llegar. Pero estas ideas del maravilloso país no son fáciles de alcanzar ya que - como hemos mencionado anteriormente - la autoridad colonial en París y en Argel no mostraba mucho ánimo a la hora de recibirlos de manera "oficial", sino contrariamente, eran dejados a su suerte, sin control y sin restricción hasta I880, cuando empezaron a mostrar un rechazo a todo tipo de emigración mediterránea, enfocándose paralelamente en captar más a los franceses para la colonización ${ }^{26}$.

El crecimiento demográfico - ya resuelto después de ser un problema frente a la colonización - permite que las autoridades colonizadoras piensen en controlar las entradas de malteses y, sobre todo, de españoles, a los que siempre vieron con ojos de menosprecio. Es cierto que a partir de 1880 ya se oían voces que alertaban del peligro de las comunidades extranjeras, las cuales ponían en riesgo el equilibrio demográfico y, por consiguiente, todo el futuro de la Francia colonial en Argelia. Maurice Wahl, en I882 se manifestaba abiertamente contra la presencia de "estos muchos" extranjeros que podría poner en peligro el futuro de Francia: «la présence de tant d'étrangers constitue un embarras dans le présent et un péril pour l'avenir» ${ }^{27}$ y añade, refiriéndose más sobre la pertinencia y pertenencia de Argelia a Francia, en torno al control de las fronteras para organizar la llegada de extranjeros: «nous n'avons pas conquis l'Algérie pour en faire un pays cosmopolite; terre française elle est; terre française elle doit rester», y propone que «Il faudrait d'abord surveiller soigneusement l'arriver des émigrants, surtout des Espagnols, n'admettre que les gens pourvus de papiers en règle et de moralité constaté, expulser sans merci les vagabonds et les dangereux; toute l'hospitalité du monde ne saurait pas nous obliger à recevoir chez

26 A partir de 1848 la autoridad francesa ponía trabas que dificultaban la entrada de inmigrantes mediterráneos a Argelia, por ejemplo poseer 400 francos en efectivo para poder tener permiso de entrada.

27 Cf. Jeannine Verdes-Lerous, Les Français de l'Algérie de 1830 à aujourd'hui, une page d'histoire déchirée, París, Fayard, 2001, p. 205, citado en Marie Muyl, Les français de l'Algérie: socio-histoire d'une identité, Thèse de Doctorat, París I, 2007, p. 51. 
nous le rebut des autres peupless ${ }^{28}$. Efectivamente, en la Revue de l'Afrique Française se pone de manifiesto el peligro de la supremacía del elemento extranjero sobre el francés: «Mais quels colons devons-nous chercher le plus à attirer, les Français ou les étrangers? Et parmi ceux-ci, devons nous établir des distinctions?? ${ }^{29}$.

Cabe mencionar que este miedo y rechazo a las comunidades española y maltesa no es casualidad, sino que está fundado en hechos reales ${ }^{30}$ : en I84I, había en la región de Orán 2.999 del elemento español frente a r.606 de franceses. En toda la geografía argelina el total de los primeros asciende a 9.748 mientras los franceses se calculan en II.508 almas. En este mismo año se calcula que había 3.795 malteses en el este argelino, y en I845 más de 8.074, y en I851 el total es de 7.307. Hay que mencionar que en I843 había un total de 28.000 emigrantes franceses que venían a Argelia frente a 31.000 de nacionalidades europeas. Estas cifras se doblan en 1846 donde sólo en Argel se calcula que había 2.969 franceses frente a 6.356 de nacionalidad española ${ }^{31}$. Los españoles en 1858 representan el $28 \%$ de los europeos censados. Las dos décadas siguientes a esta fecha los españoles casi se igualan con los franceses: 26.365 frente a $27.772::^{32}$

Españoles y franceses en el Oranesado en I886

\begin{tabular}{|c|c|c|c|c|c|}
\hline & Mascara & Mostaganem & Orán & $\begin{array}{c}\text { Sidi Bel } \\
\text { Abbés }\end{array}$ & Tremecén \\
\hline Españoles & 6.701 & 5.951 & 58.670 & 14.855 & 4.648 \\
\hline Franceses & 7.775 & 11.093 & 30.485 & 6.615 & 5.994 \\
\hline
\end{tabular}

Fuente: Jordi, Jean-Jacques: Espagnol en Oranie: Histoire d'une migration. p. 28.

28 Ibid.

29 Rochaid Dahdah, "Les colons étrangers en Algérie-Tunisie", Rerue de l'Afrique Française, París, 1886, fasc. 19, tom. IV, p. 341.

$30 \mathrm{La}$ correspondencia entre el Consulado de Francia en Alicante y el Ministerio de Asuntos Exteriores en París recogida y clasificada por Manuel Valero Iváñez, nos da una visión bastante clara de las preocupaciones sobre la emigración clandestina, sobre todo del sur español y Argelia, así como las epidemias, el comercio y el trasporte marítimo. Véase: Valero Iváñez Manuel, "E1 Norte de África en la documentación del Consulado francés en Alicante durante el S. XIX", Anales de Historia Contemporánea, Universidad de Murcia, 1984, vol. 3, pp. 245-254.

31 Carette, loc. cit., 1856, p. 105.

32 Jean-Jacques Jordi, Espagnol en Oranie, Histoire d'une migration 1830-1914, Montpelier, Africa Nostra, 1986, p. 10. 
Ahora bien, desde que los franceses iniciaron la colonización de Argelia, los malteses habían mostrado su satisfacción de manera abierta. Por una parte, los malteses querían ver la tierra norteafricana bajo control de un país fuerte y occidental, y por otra parte, querían cambiar a los ingleses por franceses con el deseo de mejorar sus condiciones de vida $y$, sobre todo, oponerse a los británicos, quienes desde el comienzo del siglo XIX no habían hecho nada más que agravar los problemas ya existentes, tales los altos precios, el trabajo reservado a los ingleses, las diferentes enfermedades, epidemias, la sobrepoblación y las calamidades agrícolas. En efecto, las autoridades británicas a lo largo del siglo XIX no habían establecido mecanismos ni política que permitieran mejorar el nivel de vida de los malteses, sino contrariamente, habían seguido una política pasiva sin mostrar ningún compromiso ni responsabilidad para mejorar sus condiciones de vida.

No obstante, el porqué en este sentido es doble: por una parte, los ingleses no querían dispensar fondos públicos para organizar una emigración controlada y organizada (solución inmediata para salir de los problemas internos) ${ }^{33}$; y por la otra, querían que los malteses saliesen de Malta por sus propios medios, ya que éstos preferían el Mediterráneo a lugares más lejanos. Los más cercanos eran Argelia y luego el vecino Túnez, colonizados por Francia, potencia rival de los ingleses. Pero sí a partir de 1870 , sobre todo tras la crisis económica de 1873 , la autoridad maltesa se propuso organizar la emigración de acuerdo con las autoridades francesas en Argelia. Sin embargo, la respuesta de estos últimos era decepcionante, ya que no mostraban ningún interés en colaborar con ellos. Esta negativa se manifestó clara y rotundamente en I832, cuando se excluye al elemento maltés de cualquier plan de colonización ${ }^{34}$. Los malteses aunque capaces y sobrios para soportar la dureza de los trabajos en la primera fase de la colonización, eran menos deseados por las autoridades

33 Hay que recordarse que antes de esta fecha, existieron muchos intentos de organizar y oficializar la emigración maltesa a otros países, fracasados todos: La Cefalonia (1826-1832), La Guiana (1838-1841), Trípoli (1849-1850), Jamaica (1872-1874), Chipre (1878-1880), y Australia (1881-1884).

34 Para acercarse a este tema véase Xavier Yakono, "La régence d'Alger d'après l'enquête des commissions de 1833-1834”, Revue de l’Occident Musulmane et de la Méditerranée, 1966, vol. 1, núm. 1, pp. 229-244. 
francesas, ya que en su mayoría eran muy pobres, cualidad que les dejaba al margen de los emigrantes europeos deseados. También el maltés, por su carácter y su fisionomía se parecía al árabe, y eso lo convertía en el menos aceptado por los franceses y por las autoridades, como afirman los cónsules ingleses, son "des étrangers pour les quels les fonctionnaires français ont les moins de sympathie" 35 .

Esta negatividad sobre el elemento maltés también se mostraba a través de los escritos de la época. Efectivamente, los franceses desde los primeros años de la colonización mostraron miedo a la presencia de mahoneses y malteses, sobre todo en la ciudad de Argel. En I834, Genty du Bussy (1834: 84) escribe alertando de la presencia masiva de malteses: «nous avons à nous défendre des émigrations répétées des Baléares et de Malte; nous avons de sages précautions à prendre. En laissant à l'Europe entière la liberté de nous expédier des colons, restons au moins les maitres de ne les accepter que quand ils nous conviennent». Para los ingleses, los malteses eran considerados como orientales, son como dice Sir Victor Houlton (Chief Secretary): «ils nont absolument rien de l'Anglais dans leur caractère et ils acceptent une décision d'une autorité supérieur (...) dans un esprit entièrement oriental» ${ }^{36}$.

Los testimonios acerca de la comunidad maltesa son, en su mayoría, muy negativos, tanto de los responsables franceses e ingleses como de los simples colonos. El cónsul inglés describe, en I832, el trato de los franceses a los malteses de manera negativa, menos cordial y muy poco simpática: «les Français n'aiment pas du tout les Maltais et ne perdent jamais une occasion de les punir, si leur conduite n'est pas bonne; ils leur causent beaucoup d'ennuis» ${ }^{37}$. Igualmente la comunidad española no ha merecido muchos elogios por parte de los colonos franceses de la época ni tampoco por las autoridades coloniales en Argelia ${ }^{38}$. El colectivo maltés, en efecto, tuvo la misma suerte que ellos.

35 Donato, ob. cit., 2012, p. 8.

36 Houlton Victor, citado en Claude Liauzu, Histoire des migrations en Méditerranée Occidentale, Complexe, Coll. Questions au XXe. Siècle, 1996, p. 33.

37 Lettre du Consul Saint- John, 3 juin 1832, citado en Émile Temime, ob. cit., p.38.

38 Djamel Latroch, "Españoles en el Oranesado: emigrantes españoles en el oeste argelino (1830-920)”, Hesperia. Culturas del Mediterráneo, especial Argelia, 2014, vol.1, núm. 18, pp. 12-26. 
Pasados ya más de dos décadas, el rechazo a las comunidades mediterráneas es muy llamativo. Las dos comunidades emigran por razones económicas, buscando trabajo y tranquilidad para poder sobrevivir por causa de las miserables condiciones de vida en sus países de origen. Hay que recordar que, en su mayoría, son analfabetos, sin recursos económicos, trabajadores que ejercen funciones que ayudan al desarrollo político y económico de la empresa colonial: «Si certains hommes nétaient pas préférés à certains autres, les populations urbaines afflueraient tandis que la terre manquaient de bras; que déjà parmi les Espagnols et les Maltais, reçus avec tant de légèreté, la plupart exerçaient un trafic, un brocantage, et que bien peu avaient loué leur travail aux colons cultivateurs" 39 . Son como ya hemos mencionado anteriormente, muy poco deseados, no obstante, imprescindibles para la buena marcha de la colonización. El trabajo de los malteses como de otras comunidades mediterráneas son «des occupations, importantes, et même indispensables pour la bonne marche de l'entreprise coloniale, qui assure à longue une installation durable, avec la complicité des autorités, qui ne les favorisent guère, mais qui finissent tout de même par les accepter» ${ }^{40}$.

Por su parte, el autor de La colonisation de l'Algérie escribe en I856, mostrando este aspecto negativo sobre los malteses vistos por los colonos franceses: «les Maltais sont les étrangers pour lesquels la plupart des fonctionnaires et des colons français éprouvent le moins de sympathie. On leur trouve de la superstition et des allures grossières; on prétend qu'ils ne sont point à la hauteur de la civilisation» ${ }^{41}$. Casi todos los colonos franceses vieron a los malteses con ojos de menosprecio por su carácter físico y por la extrema pobreza que presentaban, aunque el cónsul francés en Malta había sido favorable a la emigración maltesa hacia Argelia, sobre todo en los primeros años de la colonización, por motivos políticos y religiosos. Efectivamente, los malteses no ponían resistencia ni miedo al estar en suelo argelino y de igual manera, eran muy católicos, lo que podía ayudar de modo efectivo a la cristianización de Argelia por ser cercanos al idioma árabe y a la climatología mediterránea ${ }^{42}$. Esta similitud entre las

39 Procès-verbaux et rapports de la Commission nommée par le Roi le 7 juillet 1833, París, Imp. Royale, 1834, p. 95.

40 Temime, ob. cit., 1987, p. 41.

41 Louis Baudicour, La colonisation de l'Algérie, ses éléments, París, Jacques Lecoffre, 1856, p. 181. 42 Nathalie Bernardie, Malte, parfum d'Europe, souffle d'Afrique, Burdeos, Coll. Iles et Archipels, 
lenguas árabe y maltés, así como la similitud de los aspectos físicos son, para Montezon, razones suficientes de mala fama de las dos etnias, a ojos franceses: "mais comme chaque médaille a son revers, ils (los malteses) tiennent de l'Arabe par la sobriété, ils sont aussi bérité de sa ruse, de sa fourberie et de son penchant au vol't3.

Tanto la autoridad colonial francesa como los intelectuales franceses prefieren que los franceses tomen el control de la vida política y económica de Argelia dejando en segundo lugar a las demás comunidades mediterráneas como auxiliares cuando se les necesiten. En este sentido P. Leroy se pone de acuerdo con la orientación de la autoridad colonial en París criticando a los "populistas"—según su propio decir- que mostraban resistencia y rechazo a esta política: «le principal colon de l'Algérie restera, d'ailleurs, toujours le Français, parce qu'il a plus de ressources d'esprit et de caractère, parce que c'est lui qui apporte les capitaux et qui s'entend le mieux à tirer parti de la terre et des hommes» ${ }^{44}$. Por su parte, Muarice Wahl describe los nuevos malteses recién llegados como los menos civilizados, ignorantes y violentos: "Les Maltais nouvellement déparqué ou qui vit dans l'intérieur n'est pas encore un civilisé. Il est rude de manières, ignorant, superstitieux, violent» ${ }^{45}$.

Ahora bien, el miedo continúo de perder el control sobre Argelia originado por la numerosa presencia de las diferentes colectividades de origen mediterráneo es, según parece, la principal causa del continuo rechazo a estas poblaciones, sobre todo a partir de I848 donde, efectivamente, la política migratoria francesa se caracterizó por apartar todas las comunidades menos deseadas de cualquier participación activa en Argelia, tolerando su presencia por necesidad más que por obligación. La emigración mediterránea, sobre todo la española y la maltesa, como señala el profesor Emile Temime, es una «Migration non désirée, migration de pauvres, migration utile par son travail et aussi par la fonction intermédiaire 1999, núm. 27, p. 107.

43 M.A. Montezon, La vérité sur l'Algérie suivie de détails et de considérations, París, Feydeau, 1851, pp. 33-34.

44 Leroy, ob. cit., 1887, p. 55.

45 Maurice Wahl, L'Algérie, París, Alcan Felix, 1903, p. 235. 
quelle peut remplir entre le colonisateur et le colonisé. Cette masse déshéritée est, par la présence, symbole de l'échec de la grande migration coloniale» ${ }^{46}$.

\section{El Dorado mediterráneo}

Cuando empezó el siglo XIX, Malta entró en una nueva fase de su historia. En el mes de diciembre de I80o, el gobierno británico declara oficialmente a la nación maltesa bajo su protección. Unos años antes, Francia se había interesado en ocupar Malta por razones de seguridad para sus posesiones y para el comercio. En I797, Francia envió al secretario de la legación francesa de Génova, Mathieu de Poussielgue, en una misión para extraer informaciones, y un año más tarde, Bonaparte declaró la soberanía de Francia sobre Malta, la cual no duró mucho. En junio de I802, el congreso nacional maltés declaró reconociendo al rey de Inglaterra como soberano de Malta, después de romper con el tratado de paz de Amiens firmado entre Francia y el Reino Unido el 25 de marzo de 1802 . Esta ruptura entre las dos potencias de mayor protagonismo internacional en el siglo XIX, lleva al gobierno de Londres a reivindicar, otra vez, la soberanía de Inglaterra sobre el territorio maltés en marzo de I8I4, cuando finalmente Malta y sus dependencias se declaran estar bajo la soberanía del rey de Inglaterra.

Desde I8I4 Malta es una colonia británica. Los ingleses no tenían como finalidad el desarrollo económico del país ni de los malteses, aunque Malta se sitúa geográficamente entre Egipto y Gibraltar, escala obligatoria y necesaria para los barcos para cargarse de carbón y de alimentos. Los malteses, sin embargo, no se aprovecharon de los recursos del tránsito en sus puertos ni del comercio con los países africanos. La decepción frente a los ingleses y a los problemas políticos y económicos del país agravaron mucho la vida diaria de los malteses que, desde i820, tuvieron que salir fuera del país para poder sobrevivir o, al menos, asegurar una vida mejor, que estar bajo dominio de los ingleses. El destino preferido fue a los países cercanos geográficamente como Argelia, Túnez, Trípoli, Egipto, Turquía e Italia donde, efectivamente, se instalaron.

46 Temime, ob. cit., 1987, p. 44. 
Desde I8I4 a 1829 habían salido de Malta un total de 5.000 personas con dirección a estos países. En el periodo entre 1825-184I, emigraron 28.500 y entre I842-I850 un total de 17.500 . En I825, el 6\% de la población maltesa había salido del país; en I84I aproximadamente el r8\% salen con dirección principalmente a Argelia que es "foyer d'appel" para ellos y en I885 alcanza el 36\%. En I829, la población maltesa se estima, según Miè$\mathrm{ge}^{47}$ a II 4.236 personas, donde 79.053 son analfabetos (69\%) y 25.083 (22\%) saben leer y escribir sin ningún otro conocimiento más. Y en I842, según C. Liauzu ${ }^{48}$, II7.000 unidades. Hay que esperar a I830, fecha de la ocupación de Argelia, para que se produzca el inicio de los flujos migratorios hacia el país vecino; un país que responde a sus necesidades económicas y sociales. Cabe mencionar por último que 1836 el total de la población maltesa se sitúa alrededor de I23.I48 personas y un año después desciende a 120.792. Este descenso es debido a la emigración maltesa a Argelia principalmente ( 4.047 personas) y, claro está, a la mortalidad causada por el cólera de 1836, donde se estima que Malta había perdido 4.I55 almas.

La emigración de los malteses a Argelia viene condicionada por múltiples motivos tanto políticos como socioeconómicos. Desde 1813, reinaba en Malta el cólera, que se repitió en I830 (750 muertes) y en I837 (4.I55 muertes). Por otro lado, en I824, el algodón de Egipto se vende mucho más barato que el maltés en la propia tierra maltesa tras años seguidos de malas cosechas, provocando un gran pesimismo entre la población. Además la agricultura es muy escasa debido a la naturaleza del suelo y la escasez del espacio cultivable que se calcula en $256 \mathrm{~km}^{2}$ en 1829 . En este mismo año, se calcula que había Io.617 pobres de 23.132 que no tenían trabajo; mientras 2.333 son funcionarios del gobierno ${ }^{49}$. Por otro lado y demográficamente hablando, la densidad maltesa a mediados del s. XIX es la más alta en todo el Mediterráneo: en I829, 446 hab. $/ \mathrm{km}^{2}$ mientras 380 hab. $/ \mathrm{km}^{2}$ en 1837 ; y en 1842,372 hab. $/ \mathrm{km}^{2}$. No obstante, la tasa de natalidad oscila entre $35 \%$ a $40 \%$ (desde 1820 a 1829 son 33.126 nacidos frente a 22.967 de mortalidad: 10.I39 unidades de diferencia). En I867-68 se produjo una crisis de alimentos que a su vez provocó la subida de precios.

47 M. Miège, Histoire de Malte, Bruselas, Grégoire et Wouters, 1841, tomo 1, pp. 106-107.

48 Liauzu, ob. cit., 1996, p. 32.

49 Miège, ob. cit., 1841, p. 39-42. 
Aparte de estos problemas, hay otros que obligan a los malteses a emigrar de manera casi obligatoria a Argelia. Miège en su obra Histoire de Malte, los resume como sigue:

L'inamovibilité n'était pas assurée aux juges; les emplois supérieurs étaient toujours l'apanage des anglais; les changements opérés dans les tarifs, loin d'avoir soulagé le peuple, n'avaient eu pour résultat que aggraver sa misère; l'agriculture ne recevait pas l'encouragement; le commerce se restreignait [...] l'instruction publique était négligée pour les classes supérieures ${ }^{50}$.

Hay que recordarse que los malteses son muy católicos y están muy ligados a la religión católica (99\%). La familia para ellos es algo mucho más sagrado, casarse temprano para no caer en adulterio, así como tener una familia numerosa es una prueba de ser fiel a la religión. Efectivamente, para una familia maltesa de mediados del s. XIX es normal tener siete $\mathrm{u}$ ocho hijos de media por hogar. Las parejas se casan muy jóvenes. La natalidad tan alta, además de la sobrepoblación en una superficie saturada - la más densa en todo el Mediterráneo- provocaba todo tipo de problemas sociales graves. A partir de I830 se propuso organizar esta situación reduciendo la natalidad al aumentar la edad para casarse, y la negación a parejas de extrema pobreza a contraer matrimonio, medida que fracasó sin resultados notables. Frente a este fracaso, el gobierno optó por la emigración como una medida para solucionar los problemas de sobrepoblación y de la pobreza. En I838, por ejemplo el periódico Il mediterraneo pone énfasis en la preocupación de los malteses por la falta de subsistencia y alimentos ${ }^{51}$.

Aparte de lo anterior expuesto, la lengua maltesa, cercana al idioma árabe, la geografía semejante a la maltesa y su proximidad, el mar, el clima, son entre otros, factores que han ayudado de manera directa a la instalación de la colectividad maltesa en el litoral oriental argelino. Son comerciantes, cultivadores y agricultores en su mayoría, de clases desfavorables que ni siquiera aseguran su comida diaria, prefieren el norte de África, especialmente Argelia, más que las posesiones británicas en

50 Ibid., p. 518.

51 Il Mediterraneo, 19 de septiembre de 1838, citado en Jean-Marie Moissec, "Transition démographique et migration a Malte”, Cabiers de la Méditerranée, 1989, núm. 39, p.128. También citado en: Nathalie Bernardie, ob.cit., p. 95. 
otras tierras, con la certeza de progresar, con predisposición a adaptarse a cualquier situación tanto con los colonos de diferentes nacionalidades como con los argelinos y los judíos. Nada más llegar al litoral argelino, se ponen manos a la obra: unos — más afortunados - llevan con ellos sus cabras, único capital para su venta o explotación en Argelia. Otros, se relacionan con los judíos comerciando; otros, conocedores de la lengua árabe, trabajan como interpretes entre argelinos y franceses; otros conocedores de la marina, trabajan como buceros, cargadores y pescadores en los puertos de Bona y Skikda.

Ya pasados unos cuantos años, se adaptan al clima y a la nueva vida en tierras norteafricanas donde, efectivamente, trabajan por su cuenta propia tras duros años de ahorro, vendían carne de cabra de "raza maltesa" en las ciudades a los colonos y a los habitantes de la ciudades; unos vendían frutas y legumbres que ellos mismos cultivan en pueblos colindantes ${ }^{52}$, otros prefieren trabajar como comerciantes ambulantes vendiendo artículos fabricados por ellos mismos. Los malteses o los "árabes cristianos", calificativo que les dan por ser cercanos al idioma árabe y por parecerse a la fisionomía norteafricana, saben sacar partido de las oportunidades que se les brindaban. Sobrios, muy trabajadores, ahorradores, y amantes a la calma y la tranquilidad, a diferencia de los españoles, su única finalidad es ganar dinero lo más pronto posible para salirse tempranamente de sus miserias. La política, en efecto, les importaba poco. En el periódico Progrès de l'Algérie en I89I, se escribe que "les Maltais, il faut l'avouer, n’ont pas, n'ont jamais eu l'ardeur guerrière qu'ont presque toutes les populations européennes, ils aiment mieux cultiver des carottes et des navets dans un champ, vendre des denrées ou des liquides dans une boutique ou un cafe"

En las primeras décadas forman una sociedad aparte, no se mezclan con los franceses, sino que viven en su mundo. Sin embargo, con el tiempo empiezan a tener relaciones comerciales y luego sociales con casi todos los componentes de la sociedad argelina. Reservan su lengua y sus costumbres como señas de identidad e incluso su manera de vestirse. Pero a finales del siglo Xıx, ya empiezan a tener cierto comportamiento francés, hablando la lengua de Molière, se relacionan con todos, por motivos

52 Montezon, ob. cit., 1851, p. 10.

53 Progrès de l'Algérie. Constantina, mardi 15 septembre 1891, núm. 174. 
de sus comercios, adoptando hábitos y ritos franceses. Los hijos de las familias modestas iban a los colegios franceses e incluso a París para terminar sus estudios: «au bout de deux ou trois générations, on ne reconnait plus le paysan fruste et superstitieux qui à débarqué jadis pieds nus et la veste sur le bras» ${ }^{54}$. Se visten a la moda y sólo tienen relación con su país natal al necesitar documentos administrativos o informarse sobre algún trámite administrativo. Las mujeres, ya mayores de edad, son solicitadas en matrimonio por sus compatriotas: "à peine en âge de se marier, elles sont demander par leurs compatriotes. Le mariage n'est pas attendu longtemps (...) gardée a vue, ne peut plus sortir de la maison... ${ }^{55}$.

La labor de los malteses en Argelia fue sorprendentemente considerable. En la agricultura habían introducido técnicas para aumentar la productividad desde los primeros años de su instalación, la carne y el queso de las cabras de raza maltesa tuvieron fama entre colonos y argelinos por su calidad y su baratez. Otros con más suerte, ocupan altos grados en el ejército francés, como el caso del barón de Piro que fue coronel en Constantina en I853; el capitán M. Perini que sirvió durante treinta años hasta su muerte en Constantina, el teniente André Gatt (Abderrahmane el Malti) muerto en 1897, nombrado Caballero de la Legión de Honor por su trabajo. Aparte de los militares, algunos malteses han tenido fortunas muy considerables en Argel y Constantina ${ }^{56}$, tras trabajar duramente como agricultores o comerciantes, otros, ya adinerados, profesaban el "comercio del dinero", competidores con los judíos o algunos árabes ${ }^{57}$. Otros, con nivel de altos estudios, profesaban la medicina, como el caso de Charles Eugène Finech, nacido en Malta y muerto en Bona en I842.

\section{Conclusiones y APÉNDice estadístico}

La comunidad maltesa al igual que otras comunidades mediterráneas fue la menos deseada por la Francia colonial en las dos primeras décadas de la colonización debido a su propia naturaleza. El miedo a perder el

54 R. Vadala, "Lémigration maltaise en pays musulmans", Revue du Monde Musulman, 1911, vol. XIV, núm. 1, p. 48.

55 Baudicour, ob. cit., 1856, p. 181.

56 Cf. Wahl, ob. cit., 1903, p. 235.

57 Demontés, ob. cit., 1906, p. 455. 
control de Argelia y la pasividad de la llegada de colonos franceses permitió que las comunidades mediterráneas se instalesen espontáneamente en Argelia, toleradas para solucionar el desequilibrio demográfico, y luego fueron vistas como una amenaza frente a la seguridad de la empresa colonial.

Población maltesa en Argelia

\begin{tabular}{|c|c|c|c|}
\hline Año & Malteses & Año & Malteses \\
\hline 1833 & 1.213 & 1861 & 9.378 \\
\hline 1836 & 1.802 & 1866 & 10.627 \\
\hline 1841 & 3.795 & 1872 & 11.512 \\
\hline 1845 & 8.047 & 1876 & 14.220 \\
\hline 1851 & 7.307 & 1877 & 14.313 \\
\hline 1856 & 7.114 & 1881 & 15.402 \\
\hline
\end{tabular}

Fuente: René Ricoux, La démographie figurée de l'Algérie (1880).

Natalidad maltesa en Argelia I876-I90o

\begin{tabular}{|c|c|c|c|c|c|}
\hline Año & nacimientos & Año & nacimientos & Año & Nacimientos \\
\hline 1876 & 518 & 1885 & 574 & 1894 & 471 \\
\hline 1877 & 532 & 1886 & 584 & 1895 & 398 \\
\hline 1878 & 522 & 1887 & 539 & 1896 & 419 \\
\hline 1879 & 527 & 1888 & 490 & 1897 & 430 \\
\hline 1880 & 500 & 1889 & 514 & 1898 & 394 \\
\hline 1881 & 569 & 1890 & 404 & 1899 & 438 \\
\hline 1882 & 582 & 1891 & 411 & 1900 & 452 \\
\hline 1883 & 608 & 1892 & 379 & & \\
\hline 1884 & 600 & 1893 & 422 & & \\
\hline
\end{tabular}

Fuente V : Demontés: Le peuple algérien, essai de démographie algérienne. (1906). 
72 Djamel Latroch

Mortalidad maltesa en Argelia 1876-1902

\begin{tabular}{|c|c|c|c|c|c|}
\hline Año & mortalidad & Año & mortalidad & Año & Mortalidad \\
\hline 1876 & 373 & 1885 & 455 & 1894 & 332 \\
\hline 1877 & 407 & 1886 & 479 & 1895 & 412 \\
\hline 1878 & 569 & 1887 & 497 & 1896 & 356 \\
\hline 1879 & 399 & 1888 & 447 & 1897 & 267 \\
\hline 1880 & 412 & 1889 & 704 & 1898 & 296 \\
\hline 1881 & 438 & 1890 & 394 & 1899 & 305 \\
\hline 1882 & 458 & 1891 & 480 & 1900 & 307 \\
\hline 1883 & 406 & 1892 & 347 & 1901 & 341 \\
\hline 1884 & 468 & 1893 & 378 & 1902 & 272 \\
\hline
\end{tabular}

Fuente: V. Demontés, Le peuple algérien, Essai de démographie algérienne (1906).

Población maltesa y total de europeos en Argelia

\begin{tabular}{|c|c|c|}
\hline Año & Malteses & Total de europeos \\
\hline 1833 & 1.213 & 7.812 \\
\hline 1836 & 1.802 & 14.561 \\
\hline 1841 & 3.795 & 37.374 \\
\hline 1845 & 8.047 & 95.321 \\
\hline 1851 & 7.307 & 131.283 \\
\hline 1856 & 7.114 & 160.798 \\
\hline 1861 & 9.378 & 192.646 \\
\hline 1866 & 10.621 & 217.099 \\
\hline 1872 & 11.512 & 245.117 \\
\hline 1876 & 14.220 & 311.462 \\
\hline 1881 & 15.402 & 385.362 \\
\hline 1886 & 15.533 & 436.457 \\
\hline 1891 & 14.677 & 485.973 \\
\hline 1896 & 13.986 & 536.006 \\
\hline 1901 & --- & 583.844 \\
\hline
\end{tabular}

Fuente: V. Demontès : Le peuple algérien, essais de démographie algérienne (1906) 


\title{
EL LÉXICO ESPAÑOL EN AÏN TEMOUCHENT
}

\author{
Faiza Mechernene \\ Universidad Abou Bakr Belkaid de Tremecén
}

\begin{abstract}
Resumen
Estudio del léxico hispánico presente en el habla de la localidad de Aïn Temouchent, población ubicada en la región occidental de Argelia. Gracias a un estudio estadístico y sociolingüístico previo, se presentan en este artículo los resultados de la investigación. Se reproduce un glosario de hispanismos léxicos propios de esta región, incluyendo cada entrada detalles y ejemplos de su uso en la variante dialectal del árabe de Aïn Temouchent.
\end{abstract}

Palabras clave: Español en Argelia, Aïn Temouchent, lexicología, hispanismo léxico.

\section{ObJeto, MEtodología y ESTRUCTURA}

En el año 2015 defendimos nuestro trabajo final del máster en lengua y comunicación, dentro de la sección de español de la facultad de letras y lenguas de la Universidad Abou Bakr Belkaid de Tremecén. El trabajo llevaba por título El léxico español en el oeste de Argelia: Ä̈n Temouchent como paradigma, y estaba dirigido por el profesor Salah Eddine Salhi. Presentamos a continuación una breve descripción de sus características, objeto y metodología, junto a las principales conclusiones de este trabajo de investigación.

El marco inicial de aproximación pretendía un enfoque sociolingüístico en el que intentábamos analizar todo hispanismo usado en el habla de la ciudad de Aïn Temouchent, ubicada en el occidente argelino. La riqueza de la situación lingüística en Argelia la convierte en una fuente fértil de investigaciones. De hecho, el marco lingüístico de Argelia ha experimentado y continúa experimentando cambios significativos como resultado de la coexistencia de múltiples idiomas y variedades dialectales. Como la historia testimonia, la geografía de la actual Argelia fue cruce de caminos desde el inicio de los tiempos, se sintió atraída por diversas civilizaciones, y la han gobernado dinastías de bereberes, árabes y turcos otomanos, además de franceses y españoles. Esta última nación es uno de 
los países cuyas tropas han permanecido más tiempo en la costa argelina, más de trescientos años, notablemente en las zonas del oeste, Orán, Aïn Temouchent, Mostaganem, Tremecén, Saïda, Sidi Belabés o Béchar.

Los habitantes del oeste de Argelia, a través de su coexistencia con el elemento español, han adoptado a lo largo de tantos años de convivencia y vecindad española una mezcla de culturas y códigos con influencia hispánica patente en su naturaleza social, cultural, gastronómica, folclórica y, por supuesto, lingüística. Esta última se manifiesta en forma de préstamos, léxicos o interferencias que tienen origen en el sistema español, y se integran en el dialecto vernáculo de Argelia, especialmente en la variante local occidental.

Durante nuestra investigación, hemos abordado el habla cotidiana de los habitantes de la llamada "perla de Orán”, la ciudad de Aïn Temouchent. Hemos intentado identificar, en la dariya o el habla dialectal que ellos emplean, los préstamos lingüísticos resultado del contacto de la lengua española con el árabe dialectal, lenguas cuyas estructuras son totalmente diferentes. Nuestro objetivo general en ese trabajo de fin de máster ha sido descubrir y construir el corpus de préstamos lingüísticos de origen español, circunscritos dentro del sistema del árabe dialectal, para dar explicación al fenómeno lingüístico del hispanismo. Así pues, hemos centrado nuestro estudio en la identificación de los hispanismos que los habitantes de Aïn Temouchent preservan en su habla.

Los objetivos específicos que nos proponemos en este trabajo implican, en primer lugar, un acercamiento al elemento histórico y sociolingüístico de la comunidad de hablantes de esta zona. En segundo lugar, es necesario recopilar el material léxico del español, sobre el que se realiza un glosario de los vocablos de origen español utilizados en esta zona, para pasar a comprobar su etimología, su definición en diccionarios españoles, con el fin de analizar todas las palabras de origen español, viendo si han mantenido el mismo sentido tan como se define los diccionarios.

A partir de los antecedentes históricos y los diferentes periodos en los que los españoles se instalaron en el oeste de Argelia, vamos a estudiar los elementos lingüísticos que presentan, a su vez, el contacto adquirido desde hace tiempo por los autóctonos y de ahí nos preguntamos: ¿En qué medida ha afectado el léxico español al habla del oeste de Argelia?, 
¿qué han preservado hasta ahora los habitantes de Ain Temouchent y sus alrededores de este legado lingüístico?, ¿qué generó ese contacto de lenguas?, ¿qué préstamos lingüísticos encontramos actualmente en esa habla? y ¿̇qué interferencias se han producido entre los dos códigos lingüísticos?

Éstas son las preguntas que animan nuestro interés en la realización de este trabajo de investigación, con el fin de lograr poner en evidencia la presencia de los hispanismos en el habla argelina, concretamente en Aïn Temouchent, y tratar de dar algunas respuestas a la problemática planteada. El interés que nos llevó a profundizar en la línea de la dialectología y la sociolingüística es el factor importante que presentan esas dos disciplinas para elaborar nuestro trabajo.

Tras muchos viajes a la mencionada ciudad para realizar encuestas y entrevistas, hemos recopilado el material léxico, con el fin de explicar los fenómenos semánticos a partir de un campo léxico sociolingüísticamente perfilado. Esta tarea se realizó con puntos de selección específicos, en los principales barrios de Aïn Temouchent, en el puerto con los pescadores de Bouzedjar, en las casas de algunas familias y algunas amigas, y en lugares públicos.

En cuanto a la división de los capítulos, el primer capítulo lo dedicamos a los antecedentes históricos de la zona oeste de Argelia. Es decir, tratamos la presencia española en el Oranesado desde principios del siglo XVI hasta finales del siglo XX, pasando a la lucha de los habitantes de la ciudad de Aïn Temouchent contra los colonos españoles, haciendo hincapié en el fenómeno de la emigración hacia Argelia, y su influencia e impacto sobre la cultura española en Argelia, concluyendo con el multiculturalismo, interculturalidad e interculturalidad. En el segundo capítulo, el cual abarca la lengua y la sociedad, tratamos, en parte, la labor teórica del campo de la sociolingüística, y luego, pasamos a describir los distintos fenómenos lingüísticos que se pueden dar en un contexto de lenguas en contacto, entre la población autóctona de las ciudades del oeste de Argelia (Ain Temouchent como paradigma), con la del extranjero o el inmigrante, tales como: el bilingüismo, la diglosia y el préstamo lingüístico. Estos fenómenos nos ayudan a justificar de forma científica los cambios que han afectado a la lengua de los autóctonos. Hacemos también una referencia sobre el significado del hispanismo, y terminamos 
este capítulo con la situación sociolingüística en Aïn Temouchent, para valorar la particular diversidad lingüística que existe en esta ciudad situada en la costa occidental de Argelia.

El tercer y último capítulo aborda la parte empírica del trabajo sociolingüístico partiendo de una muestra. Se ha necesitado distribuir los cuestionarios según el grado de escolaridad, sexo y generaciones, según la residencia, según los hablantes del español en fecha 2015, según el dominio en el que se utiliza el léxico español y, el último campo, según los usuarios del español en el dialecto vernáculo. Pasamos a dar una breve observación de la encuesta y el corpus. Entonces, constituyendo un cuestionario personal lingüístico de los informantes que contiene unas preguntas sobre los hispanismos más utilizados en el habla de los habitantes de Aï Temouchent, se interpretan las entrevistas. Finalizamos este capítulo con una interpretación de los hispanismos, con un breve estudio morfológico, fonético y semántico, en el que analizamos con profundidad la tipología de los hispanismos utilizados en las diferentes partes de la comunidad. Terminamos con un estudio sobre la toponimia hispánica en el área de estudio.

Señalamos que dentro de cada capítulo, hemos elaborado breves introducciones y breves conclusiones que resumen el desarrollo de cada uno, y constituyen un nexo entre un capítulo y otro.

Nos hemos acercado a aquellas obras que podían ofrecer una información más acorde con los objetivos propuestos. Así, para lo referente a la historia de Argelia, hemos tratado obras tales como las de Juan B. Vilar, Emigración española a Argelia (I830-I900), Los españoles en la Argelia francesa (I830-I9I4), Moreno Fernández en su artículo, "El español en el norte de África", las tesis doctorales de Ahmed Kaddour, Contribución al estudio de los hispanismos en el oeste de Argelia: corpus léxico, análisis fonético morfológico y semántico; Miloud Reguig, Ain Temouchent, a través de la edad; y Mohammed Kali, Ain Temouchent, le temps de la colonie, y para la metodología Marc Jaquemain, Méthodologie de l'enquête.

Para facilitar la parte práctica, hemos escogido también obras relacionadas con las disciplinas Sociolingüística y Dialectología. En esta línea, podemos citar lingüistas notables que se interesaron en el estudio de la presencia del léxico español en el habla de los argelinos, como Benallou 
Lamine (1992), Moussaoui Meftah Meriem (1992) y (2004), Moreno Fernández (1992), y Ahmed Kaddour (2013).

\section{Glosario de hispanismos en Aïn Temouchent}

A continuación damos una lista con los principales resultados de nuestra investigación, detallando el hispanismo, la etimología y un ejemplo en dialecto argelino donde aparezca el uso de la palabra:

\section{Abogado, da [bo'yado] n. m. yf.}

ETIM. del lat. advocātus

Por ej. "Khaṣni bogädo bāch yfrili had lproblām" "Necesito un abogado para resolver mi problema"

\section{Ajedrez [ $\left.a^{\prime} \operatorname{traj} x\right]$ n.f.}

ETIM. Del ár. hisp. aššațranğ o aššițranğ, este del ár. clás. šiṭranğ, este del pelvi čatrang, y este del sánscr. čaturanga 'de cuatro miembros'

Por ej. "Ayā mgāya nlagbou chätränj”" "Mohamed, vamos a jugar el Ajedrez"

\section{Alubia ['lußja] n. m.}

ETIM. del ár. hisp. allúbya, este del ár. clás. lúbiyā’, y este del persa lubeyā

Por ej. "Lubiya had lyamat raha ghalya" "Alubia está muy cara en estos días"

\section{Anchoa [lan'\}oa] n. f.}

ETIM. Del lat. apiuva, de aphye, y este del gr. à $\varphi v ́ \eta$

\section{Armario ['marju] n. m.}

ETIM. del lat. armarüum

Por ej. "Had Lmariu rah maamer belkach" "Este armario está lleno de ropa"

\section{Arrancar [řanek] v. intr.}

ETIM.de or. inc. Coromines lo da por derivado de una forma antigua "esrancar", a su vez del provenzal antiguo "ranc" o el francés antiguo "ranc"

Por ej. "Aya ranek aaliya" "Arranca" 
Astuto, ta [s'tut] [s'tuta] adj.
ETIM. Del lat. astūtus
Por ej. "Khouk sghir setuut" "Tu hermano pequeño es astuto"

Bacina [ba'sina] n. f.

ETIM.del lat. mediev. bacia

Por ej. "Jibli lbasina taa Ima" "Tráeme la bacina de agua"

\section{Balde [ßalde] n. m.}

ETIM. de or. inc.

Por ej. "Aatini lbalde bach njib sima" "Dame el balde para traer el cemento"

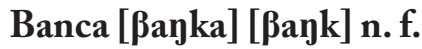

ETIM. de banco, asiento

Se utiliza para significar un asiento. Por ej. "yallab njemzou fi hada lbanc" "Vamos a sentarnos en esta banca". Y otro sentido, Por ej. "Rani rayeh lel banca" "Voy a la banca".

\section{Barco $[\beta$ arko] n. m.}

ETIM. de barca

Por ej. "Lbarco kelaa" El barco salió"

\section{Barato [ba'rato] n. m.}

ETIM. de baratar

Una palabra utilizada, cuando compran una cosa de poco precio o si encuentran el mismo tipo de algo en gran cantidad en todos mercados.

Por ej. "Rouh l'soug koulchi rah barato" "Vete al mercado todo está barato"

\section{Barra [ßařa] n.f.}

ETIM. de or. inc. quizás del latín vulgar.

Por ej. "Farid dreb sabbeh belbarra taa lehdid” "Farid golpeó su amigo con una barra de bierro"

\section{Barraca [ba'řaka] n. f. ETIM. del Cat.}


Por ej. "Hadak chibani meskin rah saken fi barraca". "Este pobre viejo vive en una barraca"

"Si Ahmed rab hal barraca ybiaa fiha dokhan" "Si Abmed se abre una barraca para vender cigarrillos"

Basta, ['basta] interj. u. tb.

ETIM. de bastar (basta, interjección procedente del imperativo de bastar)

Se utiliza para detener un escándalo, una pelea o guardar el silencio. Por ej. "Aya basta men had zega, rasi wjazni" "Basta de este alboroto, la cabeza me duele"

\section{Basura [ba'sura] n. f.}

ETIM. del lat. versūra, de verrěre, barrer

Por ej. "kis had lbasura" "Echa esta basura"

\section{Besugo [be'suyo] n. m.}

ETIM.besugo

Por ej. "Ma seydnach bzf lbesugo" No hemos pescado mucho de besugo"

\section{Betún ['biton] n. m.}

ESTIM. del lat. Bitumen

Es una mezcla de cemento y al agua, se utiliza para la construcción de casas. "Lbiton marahch mkhdoum mlih" "El betún no está bien preparado"

\section{Bobina [bu'ßina] n. f.}

ETIM. del fr. "Bobine"

Por ej. "Jibili lbobina ntaa lkhayt bach nkbayet had jipa" "Tráeme la bobina de hilo para coser esta falda"

\section{Bola ['bola] n. f.}

ETIM. del prov. bola, y este del lat. bŭlla, burbuja, bola

Esta palabra se utiliza de otro sentido para expresar el futbol. Por ej. "Wled jarna khervenli lbola taai" "Wl hijo de nos vecino me robo el balón" 
También "Lyoum nlaabou lbola maa wlad boujemaa" "Hoy, vamos a jugar balón o futbol con wlad boujmaa"

\section{Bomba ['bumba] n. f.}

ETIM. de bombo, y este del latín medieval "bombus" ("ruido"), en los clásicos "zumbido", del griego antiguo "ßó $\mu \beta \varsigma$ ” (bómbos), probablemente de origen onomatopéyico.

Por ej. "Smaatou belboumba li darouba fi felistine" "Han escuchado de la bomba que....." O otro sentido cuando alguien miente o pelea; por ej. "Malah hadek yboumbé aalina"'Porque miente esta persona"

\section{Bolsa ['bursa] n. f.}

ETIM. del lat. "bursa"

Por ej. "Aatini bursa nhout fiha had swalab" "Dame una bolsa para poner esta compra"

\section{Borracho [ba'rat $\left.\int o\right]$ adj. m. us. en desus.}

ETIM. del Cat. morratxa ("redoma")

Ebrio, embriagado por la bebida. El empapado en almíbar y vino generoso.

Por ej. "Didi barracho", Didi es un personaje de la película argelina Al-Harik, una persona intoxicada por el alcohol. Hasta la actualidad los niños del oeste de Argelia utilizan esta frase cuando juegan entre ellos "Didiii barrachooo, didiii barracho..."

\section{Borrico [bo'řiko] adj. m.}

ETIM. del lat. tardío burrīcus 'caballo pequeño

Se usa por el alumno que no estudia bien, por ej. "Borrico la clase" "Esta el borrico de la clase"

\section{Bota ['bota] n. f.}

ETIM. del fr. botte

Por ej. "Aandek lbota”" ¿Tienes botas?" 


\section{Bravo, [bravo] adj. Colq.}

ETIM. del lat. pravus, malo, inculto

Se utiliza cuando alguien hace una cosa de bueno o gana en un juego, en el trabajo o en sus estudios.

Por ej. "Bravooo!"

\section{Cacerola [kas'řona] n.f.}

ETIM. de cazo

Por ej. "AAtini casrona taa lhelib" "Dame cacerola de leche"

Cabeza [ka’ßesa] n. f. us. pop.

ETIM. del castellano antiguo "cabeça" y está bajo del lat. "Capitĩa".

Por ej: "Lcabesa andek habsa" "Tu cabeza no funciona"

Cable, ['kaßle] n. m.

ETIM. de or. inc.; quizá del b. lat. "Capŭlum", "cuerda"

Por ej. "Rani nsegued lcable taa tricite" "Reparo el cable de la electricidad"

Cabrero [ka'ßrero] n. m. y f.

ETIM. del lat. caprarĭus

Calabaza [calbosa] n. f.

ETIM. de calabaza

Por ej. "Hadi chira calbosaaa!" Esta chiquilla es como una calabaza"

Calamar [kala'mar] n.f.

ETIM. del lat. calamarǔus, de calămus, caña o pluma de escribir

Caldero [kar`ero] n. m.

ETIM. del lat. caldarĭum

Un plato que se prepara por parte de pescadores

Caldo ['kaldo] n. m.

ETIM. del lat. caldus, caliente 


\section{Calesa [ka'lif] n.f.}

ETIM. del fr. calèche, y este del checo kolesa

Por ej. "Aami Ahmed aandeh lkalish chebab" "Tio Ahmed tiene una calesa hermosa"

\section{Caliente [karaN 'tita] ['karan] ['lami] adj.}

ETIM. del lat. calens, -entis

Por ej. "Aatini mil cinq thon karantita" "Dame un mil cinco de caliente con atún"

\section{Calma ['kalma]n. f. calmar [t'kalma] v. intr.

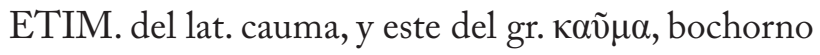 \\ Por ej. "Lcalma raha mliha" "El clima está bien"}

\section{Calzón ['kalso] n. m.}

ETIM. de calzón

Por ej: "Lbesi lweldek calson" "Pones a tu niño un calzón"

\section{Cantina [kaN'tina] n. f.}

ETIM. del it. Cantina

Puesto público en que se venden bebidas y algunos comestibles. Sótano donde se guarda el vino para el consumo de la casa. Pieza de la casa donde se tiene el repuesto del agua para beber.

\section{Capazo [ka'ßaso] n. m.}

ETIM. del lat. "capax, -ācis, capaz"

Se utiliza para la compra. Por ej. "Ma rani rayeh lelmarché aatini lcabaso" "Madre mía, me voy al mercado, dame el capazo"

\section{Carreta [ka'řita] n. f.}

ETIM.del dim. (-eta) de carro y este del lat. carrus

Dicho de un mal coche. Por ej. "Nta aandek carrita machi loto" "Tienes una carreta" 


\section{Carro ['kařo] ] n. m.}

ETIM. del lat. carrus, y este del galo carros

Por ej. "Jeddek ybiaa lkhodra fi carro?” “¿Vende tu abuelo legumbres en un carro?"

\section{Carroza [ka'řosa] n. f.}

ETIM. -del lat. Carrūca

Por ej. "Hadik chira aandha carrosa hamra" "Esta chica tiene una carroza roja"

\section{Carta ['karta] n. f.}

ETIM. del lat. charta, y este del gr. $\chi \alpha$ ó

Por ej. "Aya sabbi rwah nlaabou lcarta" Amigo vamos a jugar la carta"

También "Jibili benti lcarta taai bach nkblous" "Mi niña, tráeme mi tarjeta de identidad para el pago"

\section{Cartagena [karta 'xena] n. pro. topónim.}

Se utiliza para significar un viaje muy largo, o un lugar remoto.

Por ej. "Rah hatta lcartagena w ja" "Se fue hasta Cartagena y volvio"

\section{Chamanto [ ar'mato] n. m.}

ETIM. chalmate: quizá del náhuatl chalani, part. de ochalan, romperse, $y$ matate, red

Un objeto de tela o lana fina que sirve para cubrirse.

Por ej. "Lberd rah lyoum, ghetini bcharmato" "Hoy hace frio, cúbreme de chamanto"

Chamar [Ja'mer] v. tr.

ETIM. disc. cf. port. 'cambar', 'cambiar', fr. 'changer'

Por ej. "Aya chammer ala yeddik w khedem" "Chama y trabaja"

\section{Chumbo ['t $\int$ ambo] $n$. m.}

ETIM. del port. Chumbo (plomo) Y este del lat. plumbum. Higo chumbo.

Por ej. "Aatini chuia chambo" "Dame unos cuantos chumbos" 
84 Faiza Mechernene

Chancla ['Jangla] n. f.

ETIM. cf, chanca

Por ej. "Jibili changla" "Tráeme mi chancla"

\section{Chancleta [ ag'gleta] n. f.}

ETIM. Del dim. de chancla

Chinela sin talón, o chinela o zapato con el talón doblado, que suele usarse dentro de casa.

\section{Chaqueta [xa'kita] n. f.}

ETIM. de jaqueta

Por ej. "Hadi jaquita hamiya" "Es un chaqueta cálida"

\section{Cigarro ['gařo]}

ETIM. del maya siyar

Por ej. "A sabbi aatini garro" "Amigo mío dame un cigarro"

\section{Cintura [0eN'tura] n.f.}

ETIM. del lat. cinctūra

Parte de una prenda de vestir que corresponde a esta parte del cuerpo.

\section{Chicha ['t $\left.\int \mathrm{i} \int \mathrm{a}\right] \mathrm{n} . \mathrm{f}$.}

ETIM. de la voz aborigen del Panamá chichab, maíz

Por ej. "Emmmm! Tchicha harra" "Emm! ¡Qué buena chicha!"

\section{Cisterna [0i'tirna] n. f.}

ETIM. del lat. cisterna

Por ej. "Weldi aamer citirna raha kbawya" "Hijo, la cisterna está vacia, llénala"

\section{Cochura ['kufa] n. f.}

ETIM. del lat. coctūra

Por ej. "Lkucha taa jaretna tyeb ghaya lkbobz" "Chritlkoum lyoum croissant mel kucha" 


\section{Cocina [ko' $\theta$ ina] n. f.}

ETIM. del lat. coquīna, de coquĕre, cocer

Por ej. "Ya weldi jibli lma mel cosina" "Mi niño tráeme un vaso de agua de la cocina"

Cola ['kola] n.f.

ETIM. del lat. colla, y este del gr. кó $\lambda \lambda \alpha$

Por ej. "Lyoum lcola raha fi lbushta" "Hoy hay mucha gente en la oficina de correos"

Comisaría [komi'sarja] n. m. y f.

ETIM. del bajo lat. commissarǔus, y este del lat. commissus, part. pas. de committěre, cometer.

Por ej. "Andi aami yekbdem fi lcomisaria" "Tengo un tío que trabaja en la comisaria”

\section{Contra ['koNtra] prep. \\ ETIM. del lat. "contra"}

\section{Contrabando [tra' $\beta$ aNdo] n. m.}

ETIM. de contra y bando, edicto, ley

Por ej. "Hada chir ykbdem trabando" "Este chico trabaja de contrabando"

Corona ['grona] $\mathbf{n . f}$

ETIM. del lat. "Corōna"

Costa ['kosta] n. f.

ETIM. del gall. o cat. "Costa"

Cubierta [ku'Birta] n.f.

ETIM. de cubierto

Por ej. "Ghatini bel cubirta ysejik" "Cúbreme”

Dama ['dama] n.f.

ETIM. del fr. dame, y este del lat. dominna

Por ej. "Taaref lcarta taa damma?” "CConoces el juego de cartas de Dama?” 


\section{Dominó [do'mino] n. m.}

ETIM. del fr. domino, y este del m. or. que dómino

Por ej. "Rah aandi domino fi dar aya rwah tlaab maaya" "Vete conmigo para jugar al domino"

\section{Escalera [ska'lera] n.f.}

ETIM. del lat. "scalarīa", pl. n. de "scalāres"

Por ej. "Scalera taa lbatimat aayatni" "Las escaleras de los edificios me cansan"

\section{Escuela [sa'kwela] n. f.}

ETIM. del lat. "schola”, y este del gr. " $\sigma \chi 0 \lambda \eta ́ "$

Se utiliza para la escuela primaria.

Por ej. "Rouh jib khouk m sakuela" "Traerá tu hermano de la escuela"

\section{España [z’ßanja] n. pro.}

ETIM. España

Por ej. "rani rayeh lsbania" "Voy a España"

\section{Fábrica [fa'ßrika] n. f.}

ETIM. del lat. 'fabrǐca'

\section{Factura [fak'tura] n. f.}

ETIM. del lat. factūra

Por ej. "Wsletni lyoum lfactura taa Ima" "Hoy he recibido la factura de agua"

\section{Falta [falta] n. f.}

ETIM. del lat. vulg. "fallĭta"

Se utiliza cuando alguien hace un error o una falta.

Por ej. "Sabebti lyom daret wahed lfaltaaa" "Mi amiga ha hecho una falta"

\section{Falsa ['falsa] adj. f.}

ETIM. del lat. "falsus"

Se utiliza por parte de gente mayor (jas) cuando uno de sus niños 
hace un gran error.

Por ej. "Yaaaw derti falsa gued rasek" "Has hecho una gran falsa"

Familia [fa'milja] n.f.

ETIM. del lat. "familia"

Por ej. "Lfamilia raha ghaya?” ¿Está bien la familia?”

\section{Farda [f'rða] n. f.}

ETIM. disc.

Bulto o lío de ropa. Pero en el habla de los habitantes de Aïn Temouchent significa lo contrario, como muletilla para expresar nada.

Por ej. "Win raha lferda taa sebati" "Dónde está.... de mis zapatos"

Fiesta [fi' ta] n.f.

ETIM. del lat. "festa", pl. de "festum"

Por ej. "Lyoum lfhishta hatta wahed ma ykhdem" "Hoy la fiesta nadie trabaja"

Fideos [fda'we $]$ n. m. pl.

ETIM. quizá del mozár. y ár. hisp. fidáwš

Pasta alimenticia de harina en forma de cuerda delgada

Por ej. "Dertou lyoum fdawesh lelftour?" "Han preparado los fideos por la cena?"

\section{Flecha ['flit $\left.\int a\right]$ n.f.}

ETIM. del fr. flèche, y este quizá del franco *fleuk[k]a; cf. neerl. medio vlieke, b. al. ant. fliuca

Por ej. "Taaref tlaab jeu taz fletsha" "Sabes tú jugar el juego de flecha?"

Fondo ['foNdo] n. m.

ETIM. del lat. fundus

Forma ['forma] n. f.

ETIM. del lat. forma

Por ej. "Chouf lforma taa hadou scalerat chebba" "Mira estas escaleras tienen una buena forma" 
Francia ['fransa] n. pro.

ETIM. de Francia, viene del germánico frank, libre

Por ej. "Rani rayeh l'Fransa" "Me voy a Francia"

\section{Freno ['freno] n. m.}

ETIM. del lat. "frēnum"

Se utiliza para el freno del coche. O para una persona que habla mucho.

Por ej. "Lfreno taa loto rah aayan"“El freno de esta coche es malo" "Aya frini chuia rak msbah w nta tahder" "Para de hablar un poco"

\section{Gabardina [gaßar’ðina] n. f.}

ETIM. Cruce de gabán y tabardina, der. de tabardo.

\section{Gamba ['gamba] n.f.}

ETIM. del it. gamba, pierna, este del lat. vulg. camba, pierna de las caballerías, y este del gr. $\alpha \mu \pi \eta ́$, curvatura

Por ej. "Lyoum lgamba jat sghira" "La gamba de hoy es muy pequeña"

\section{Gamella [ga'mila] n. f.}

ETIM. del lat. camella, escudilla

Artesa que sirve para dar de comer y beber a los animales, fregar, lavar, etc.

Por ej. "Had lgamila chebba bchezal chritiha?" "Es una buena gamella! ¿Cuánto cuesta?"

\section{Garbanzo [gor'ßaN日o] n. m.}

ETIM. de or. inc.

Por ej. "Emmm! Ma lyoum raha mtyeba lgorbanzo" "Emmm! Mi madre ha preparado deliciosos garbanzos"

\section{Gato ['gat] n. m.}

ETIM.del lat. cattus

Por ej. "Lgat taai twedrli lbareh" "Ayer he perdido mi gato" 
Gitana [xi'tana] [am'řya] adj. m. y f.

ETIM. de egiptano, porque se creyó que procedían de Egipto

Se utiliza para expresar una mujer de mal vestido.

Por ej. "Had lmera ki lgitanat" "Esta mujer es como las gitanas"

Gorda ['gorða] adj. f.

ETIM.del lat. gurdus, voz de or. hisp.

Muy abultado y corpulento.

Grelo ['grelo] n. m.

ETIM. del lat. gryllus

Insecto ortóptero, grillo.

Por ej. "Rah kayen grelo henaya, lazem nketloub" "Hay un grelo aqui, debemos matarlo"

Grúa ['grua] n.f.

ETIM. del lat. grus, gruis

Guerra ['giřa] n. m.

ETIM. del germ. werra, pelea, discordia; cf. a. al. ant. wërra, neerl. medio warre

Guitarra [gi'tara] n. f.

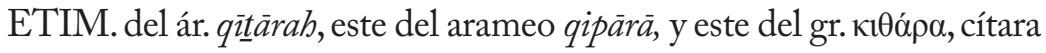

Por ej. "Hadi lguitara jabouhali cadeau" "Esa guitarra es un regalo de mi amigo"

Gurbio ['gur $\beta i]$ n. m.

ETIM. de gubia

Dicho de un instrumento de metal, que tiene alguna curvatura

Por ej. "Sabbi rah karifi wahed lgurbi allab la ycherwfek" "Mi amigo está alquilando un gurbio muy malo"

Gusto ['gusto] n. m.

ETIM. del lat. gustus 
90 Faiza Mechernene

Por ej. "Aandi lgusto fi bola" "Me gusta el futbol"

\section{Harina [fa'rina] n. f.}

ETIM. del lat. farīna

Por ej. "Khaseni lfarina bach ndir lherira" "Necesito la harina para preparar la sopa"

\section{Horno ['forno] n. m.}

ETIM. del lat. furnus

Por ej. "Teyebi lkhobz fi lforno" "Se ha preparado el pan en el horno"

\section{Hospital [zßi'tar] n. m.}

ETIM.del lat. hospitālis

\section{Japuta [xa'puta] n.f.}

ETIM. del ár. hisp. *̌abbuita, este del ár. clás. šab[b]ưt, y este del arameo šabbūtāa)

Pez teleósteo del suborden de los Acantopterigios, de color plomizo.

\section{Joder [xowa'r] interj. u.}

ETIM. de joder

Para expresar enfado, irritación, asombro, etc.

Por ej; "Hadek andeb Mercedes, jouar" "Joder, esta persona tiene Mercedes"

\section{Jurel [xu'rel] n. m.}

ETIM. del ár. hisp. šuríl, este dim. del lat. saurus, y este del gr. $\sigma \alpha \tilde{\rho} \rho \varsigma_{\text {, }}$ lagarto

Pez teleósteo marino, del suborden de los Acantopterigios.

\section{Kilo ['kilo] n. m.}

ETIM. kilo, De kilo- y gramo

Por ej. "Wzenli zouj kilo tomatis" "Pésame un kilo de Tomate"

Lámpara ['lamba] n.f.

ETIM. de lámpada 
Por ej. "Lamba taa sala nharguet" "La lámpara de la sala no funciona"

Largo(a) ['laryo] ['larya] adj. us. fig.

ETIM. del lat. largus

Por ej. "Hadek largo" "Este chico es largo"

Lejía ['lexja] n. f.

ETIM. del lat. [aqua] lixīva

Por ej. "Hadi lejia gataa" "Esta lejía es muy buena"

\section{Lista ['lista] n. m.}

ETIM. del germ. *î̂sta; cf. a. al. ant. y nórd. lîsta, ingl. list, franja, orillo

Por ej. "Lyoum afichaw lista taa lbac" "Hoy han enunciado la lista de bachillerato"

Maestro [ma'estro] adj. m.

ETIM. del lat. magister, -tri

\section{Marca ['marka] n. f.}

ETIM. del b. lat. marca, y este del germ. ${ }^{*}$ mark, territorio fronterizo; cf. nórd. mark, a. al. ant. Marka

Por ej. "Cha heya lmarca lmliba fi sechoir" "Cuál es la marca del secador" También "L'equipe marcaaat buuut" "El equipo ha marcado"

\section{Marina [ma'rina] n. pro. f.}

ETIM. del lat. marīnus

Por ej. "Jarena yekbdem filmarina" "Nuestro vecino trabaja en la marina"

\section{Marmita [mar'fita] n.f.}

ETIM. del fr. marmite

Por ej. "Lhrira raha fi lmarmita" "La sopa está en la marmita"

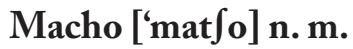

ETIM. del lat. Mascŭlus 


\section{Madrid [ma’rid] n. pro.}

Topónimo de una playa situada en Beni Saf.

\section{Miseria [mi'日irja] n. f.}

ETIM. del lat. miserǐa

Por ej. "Rana aaychin fi misiria" "Vivimos en la miseria"

\section{Motor [mo'tor] n. m.}

Por ej. "Aandi motor Yamaha" "Tengo una motocicleta Yamaha"

\section{Muca [muca] n. f.}

ETIM. del quechua muka

Para describir una mala persona.

\section{Negro ['niyru] adj.}

ETIM. del lat. niger, nigri

Por ej. "Wash nigru kach khedma" "Eh negro jestás trabajando?"

\section{Paella [pa'ela] n. f.}

ETIM. del valenciano paella

Plato de arroz seco, con carne, pescado, mariscos, legumbres, etc.

Por ej. "Chrit gaa nouaa lhout bach ntyeb lpaella" "He comprado todos tipo de pescados para preparar la paella"

\section{Pala ['bala] n. f.}

ETIM. del lat. pala

Por ej. "Aatini lbala nlem had trab" "Dame la pala para cubrir ese suelo"

\section{Paloma [ba'loma] n. f.}

ETIM. del lat. vulg. Palumba

Se utiliza de manera irónica.

Por ej. "Jaretna dayera ki paloma" "Nuestra vecina esta como una paloma"

\section{Pareja [pa'rexa] n. f.}

ETIM. del lat. paricŭlus, dim. de par, paris, igual 
Por ej. "Lbarcos mchaw pareja" "Los dos barcos se han ido en parejas"

\section{Pasarela [pas’̌rela] n. f.}

ETIM. Del it. Passerella

Se utiliza en la marina entre los pescados.

\section{Patata [ba'tata] n.f.}

ETIM. Cruce de papa y batata

Por ej. "Lbatata raha ghlya bzaf had lyamet" "La patata está muy costosa estas días"

\section{Piedra ['peðra] n.f.}

ETIM. del lat. petra

Por ej. "Nroub l'pedra lbayeda nreyah chuia" "Voy a blanca piedra para relajarme"

\section{Pintura [bN 'tura $]$ n. f. benter [bNt'r $]$ v. tr.}

ETIM. del verbo pintar

Por ej. "Ah! Hadi bentura chebba" "Esta es una hermosa pintura"

\section{Placa ['plaka] n.f.}

ETIM. del fr. plaque

Por ej. "Marakch tchouffi Iplaca taa stop" "No miras la placa de Stop"

\section{Placeta [pla'日eta] n. pro. f. cat.}

ETIM. del cat.

Es una plaza situada en el centro de la ciudad Aïn Temouchent

Por ej. "Jeddi rah gaaed maa shabah fi lplaceta" "Mi abuelo esta con sus amigos en la placeta”

\section{Plan ['blan] n. m.}

ETIM. del plano

Por ej. "Gouli waktach twejdli lblan taa dar?" "Dime ¿̨cuándo será preparado el plan de mi casa?" 


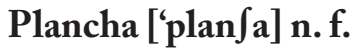

ETIM. del fr. planche

Lámina o pedazo de metal llano y delgado.

\section{Plomo ['plomo] n. m.}

ETIM. del lat. plumbum, voz de or. hisp.

\section{Policía [bu'lisja] n. f.}

ETIM. del lat. politīa, y este del gr. $\pi$ o $\lambda \iota \tau \varepsilon i ́ \alpha$

\section{Pomada [po'maða] n.f.}

ETIM. de poma

Por ej. "Tbib atani pomada taa romatiz" "El doctor me ha preescrito una pomada" También de manera vulgar, "WahTelili lpomada bech ncherilek sbat" "No me das pomada para comprarte un zapato"

\section{Popa ['popa] n. m}

ETIM. del lat. puppis, con la (a) de prora

Parte posterior de una embarcación.

\section{Poncho ['pon $\left.\int o\right]$ n. m.}

ETIM. Poncho

Por ej. "Lponcho taak chbab" "Tiene un hermoso poncho"

\section{Punto ['buNtu] n.m.}

ETIM. del lat. "punctum"

Por ej. "Ooooob bunto buntuu!» "oooh! Goool”

$\mathrm{O}$ de otra manera, por ej. "A sabbi aatini bunto taa doukban" "Amigo mio dame un cigarrillo"

\section{Ramita rama [ř́mita] n. f. bot.}

ETIM. de ramo

Por ej. "Manich aaref ramita taaek mnin" "No sé de qué ramita (clase) eres" 


\section{Remolque [ř́e'morka] n. m.}

ETIM. del v. tr. remolcar, del lat. remulcāre, y este del gr. de $\dot{\rho} \tilde{v} \mu \alpha$, cuerda, y ò $\lambda \kappa o ́ s$, tracción

Por ej. "Remorca taa l'ma" "Remolque de agua"

Río Salado n. pro. ['̌̌jo] sus. m. [sa'laðo] adj. m.

ETIM. del lat. rius, rivus, arroyo _ salado, del part. de salar

Topónimo de un municipio situado en la región de Aïn Temouchent.

\section{Roca ['̌roka] n.f.}

ETIM. de or. inc.

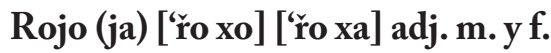

ETIM. del lat. russus

De color rubio. Dicho especialmente del cabello.

Por ej. "Hadek rojo ytchebah ghi lmab" "Este chico rubio se ve como su madre"

\section{Ronda [‘roNda] n.f.}

ETIM. voz de or. rom.

En varios juegos de naipes, vuelta o suerte de todos los jugadores. Conjunto de las tres cartas primeras que en el juego del sacanete se ofrecen a los que van a parar.

\section{Sala ['sala] n.f.}

ETIM. del germ. sal, edificio de una sola pieza de recepción.

Habitación principal de la casa.

Por ej. "Sabbeti andha laares fi sala taa al-Andalus" "Mi amiga va a hacer su matrimonio en la sala al-Andalus"

\section{Sandalia [saN'dala] n. f.}

ETIM. del lat. sandalĭum, y este del gr. $\sigma \alpha v \delta \alpha ́ \lambda ı v$

Zapato ligero y muy abierto, usado en tiempo de calor.

Por ej. "Lhoman rah, nroub nekra bsandalti" "Hace mucho calor, me voy con sandalias" 


\section{Sardina [sarðina] n.f.}

ETIM. del lat. sardīna

Por ej. "Ma syednach bzaf sardina" "No hemos pescado mucha sardina"

\section{Semana [si'mana] n. f.}

ETIM. del lat. septimāna

Por ej. "Chehal ghaya, simana jaya ma nkrawch” "Qué bueno! la semana que viene no estudiamos"

\section{Servita [š̌’bita] n.f.}

ETIM. del lat. servi

Significa la toalla para la cara.

\section{Sombrero [som'brero] n. m.}

ETIM. de sombra

Po ej. "Dir sombrero aala chems" "Este sombrero es para el sol"

\section{Sopera [su'ßera] n. f.}

ETIM. de sopa

Vasija honda en que se sirve la sopa en la mesa.

Por ej. "Win raha subera taa chourba?" ¿Dónde está la sopera de sopa?"

\section{Sota ['sota] n. f}

ETIM. del lat. subtus, debajo

La persona que dice disparates.

Por ej. "Lemra sotat" "La mujer está loca"

\section{Suma ['suma] n. f.}

ETIM. del lat. summa

Operación de sumar.

Por ej. "Chehal suma taa had sebbat?" "Cuál es la suma de este zapato?"

\section{Tabla ['taßla] n.f.}

ETIM. del lat. tabŭla

Pieza de madera plana, de poco grueso y cuyas dos caras son paralelas 
entre sí. Pieza plana y de poco espesor de alguna otra materia rígida.

Por ej. "Houti Imakla fog tabla" "Pone la comida sobre la tabla"

\section{Tambor [tambor] n. m.}

ETIM. Quizá del ár. hisp. țabbūl, hipocorístico del țabál

Instrumento musical de percusión, de madera o metal, de forma cilíndrica, hueco, cubierto por sus dos bases con piel estirada, que se toca con dos palillos.

\section{Tarta ['tarta] n.f.}

ETIM. del fr. tarte

Pastel grande, de forma generalmente redonda, relleno de frutas, crema, etc., o bien de bizcocho, pasta de almendra y otras clases de masa homogénea.

Por ej. "Klit wahed tarta taa chicula! Rawaa!" "He comido una tarta deliciosa, tarta de chocolate"

\section{Tenedor / Garfo ['garfo] [far'tita] n. m.}

ETIM. del por.

Por ej. "Kouli slata bel garfo" "Come la ensalada con el tenedor"

\section{Terco [t'ryo] adj.}

ETIM. de or. inc.

Pertinaz, obstinado e irreducible.

Por ej. "Dayera ki tergo" $\mu$ "Eres muy terco"

\section{Tisana [ti'sana] n. f.}

ETIM. Del lat. ptisāna, y este del gr. $\pi \tau \iota \sigma \alpha ́ v \eta$

Bebida medicinal que resulta del cocimiento ligero de una o varias hierbas y otros ingredientes en agua.

Por ej. "Rani m'grippé nroub nchroub tisana" "Tengo gripe, voy a tomar tisana"

\section{Tomate [to'matis] n. m.}

ETIM. del nahua tomatl 
Por ej. "Jibli zouj kilo tomatis" "Cómprame dos kilos de tomates"

$\mathrm{O}$ de us. fig. por ej. "Wjhek rah comma tomatis", "Tu cara está como un tomate"

\section{Toro ['toro] n. m.}

ETIM. Del lat. taurus

\section{Tractor [trak'tur] n. m.}

ETIM. del lat. tractus, de trahĕre, arrastrar

\section{Triunfo ['truMfu] n. m.}

ETIM. del lat. triumphus

En ciertos juegos de naipes, carta del palo de más valor.

Un juego que se juega en Aïn Temouchent y Beni Saf desde la presencia española.

\section{Vuelta [we'rta] n. f.}

ETIM. del lat. volǔta, por volūta

Por ej. "Aya ndirou werta" "Vamos a dar una vuelta por aqui"

\section{Zanahoria [0’ř̀ja] n. m.}

ETIM. del ár. hisp. safunnárya, y este del gr. $\sigma \tau \alpha \varphi v \lambda i ́ v \eta \alpha ̉ \gamma \rho i ́ \alpha$, zanahoria silvestre

\section{Zapato [z'ßat] n. m.}

ETIM. del turco zabata

Por ej. "Papa aatini necheri sebat jdid" "Papa me ha dado dinero para comprar unos zapatos nuevos"

\section{Conclusiones}

La conclusión principal de nuestro trabajo es que, hasta hoy día, los nativos de Aïn Temouchent, mayores y menores, preservan un léxico español que se presenta como contacto lingüístico entre el árabe dialectal y la lengua española en forma de interferencias o préstamos entre ambos códigos. 
Hemos recopilado más de 150 hispanismos, corpus en el que hemos descubierto interferencias entre el árabe vernáculo y el español como en los casos de zroudia-zanahoria, tomatis-tomates, charmato-calmante, remorca-remolque. Encontramos otras interferencias un poco más complejas, que se clasifican como galicismos parciales, es decir, una palabra procedente al mismo tiempo de dos lenguas y que se usa en el habla de esa zona occidental, quizás para facilitar su habla. Citamos como ejemplos la palabra vista, que toma el significado de la palabra francesa veste, y el significante de la palabra española vista. También es el mismo caso de las palabras tablall, table-tabla, firmall-ferme, firma, blouzall blouse, blusa, sabon\| savon, jabón. Constatamos finalmente la presencia del préstamo lingüístico sin alterar en casos como Madrid, placeta, chumbo, macho, etc.

Como se puede notar, el presente estudio contiene una parte teórico y una práctica. En la parte teórica, hemos realizado una lectura detallada de los antecedentes históricos de Argelia, en la que hemos resaltado y justificado las más importantes causas y consecuencias de este legado extranjero lingüístico y cultural, que existe en este país de África del norte. En base a opiniones y citas de diferentes lingüistas, hemos dado definiciones a algunos conceptos claves relativos a nuestro trabajo, tratando el contacto de lenguas, el bilingüismo, la diglosia, el multiculturalismo, interculturalismo y la interculturalidad, pasando a las actitudes y representaciones sociolingüísticas, dando una presentación acerca de la situación sociolingüística de Aïn Temouchent. Al final hemos identificado la complejidad lingüística que rodea a los habitantes de esta región. Este censo nos ha llevado a construir un marco para comprender mejor nuestra problemática. En la parte sociolingüística y gracias a las encuestas que hemos practicado, se concluye que la generación de más de 65 años utiliza mucho el elemento español en su dialecto, debido a su convivencia con los españoles antes y durante la colonización francesa. Por eso, hemos notado que hay algunos hispanismos que se encuentran en desaparición ya que no son utilizados por parte de los jóvenes que usan un árabe vernáculo mezclado con francés más que con español. Pero no se puede negar que la generación que surge usa el elemento español de manera académica, es decir, en las escuelas, institutos o durante sus viajes a España debido a un clima de mayor relación en las últimas décadas entre las dos orillas. 
Desde el corpus recopilado, confirmamos que la gente de esta región conserva un legado lingüístico cultural que se usa en diversas aéreas: la marina (herramientas navales, nombres de peces; pasarella, calma, sardina, calamar, barco, khouril...), la casa (cocina, armario, lekhia,...), la calle (arrancar, khouar...), la gastronomía y alimentación (tarta, chocolate, tomatis, zroudia, paella, chumbo, chicha, tomatis,...), los juegos (triunfo, dama,...), vestidos y calzados (sebbat, ropa, chancla, chancleta...), la toponimia (Madrid, río salado), la música (pandero, guitara,...), objetos de agricultura y albañilería (remorca, citerna, balde, maseta, masa,...), medios de transporte (carrosa, carreta, carro,...), la fauna y la flora (mancho, rasa, ramita, moca,...).

En este trabajo de investigación hemos señalado que el estudio morfológico nos orienta a poner cada hispanismo en su categoría morfológica. También hemos encontrado cambios o modificaciones y sustituciones entre las vocales y consonantes citadas en la parte del estudio fonético. En el estudio semántico se ofrece la tipología de los hispanismos, en el que hemos clasificado cada hispanismo dentro de su significado usado por parte de la población del occidente de Argelia. Y en el estudio de onomástica se ha estudiado el origen y significado de cada nombre propio.

Concluimos que la región de Ain Temouchent disfruta de una riqueza lingüística que ocupa una parte estratégica y significativa dentro de la historia cultural del occidente de Argelia. Esos elementos extranjeros participan actualmente en Aïn Temouchent en los ámbitos de la vida diaria agrícola, marítima y cotidiana, como parte consustancial del habla y la cultura locales ${ }^{1}$.

1 Texto completo de la tesis aquí resumida puede encontrarse en el siguiente enlace: http://argelina.org/wp-content/uploads/TFM-el-lexico-espanol-en-el-oeste-de-argelia.pdf 


\title{
TRADUCIENDO A WĀSĪNI AL-A'RAŶ: UN ESTUDIO MITOCRÍTICO DEL DUALISMO LÉXICO EN SU OBRA BAYT AL-ANDALUSI
}

\author{
Antonio Torres Fernández \\ Universidad de Alicante
}

\begin{abstract}
Resumen
Este artículo tiene un doble objetivo. Por un lado, traducir parcialmente el primer capítulo de una obra esencial de la literatura argelina del siglo XX: Bayt al-Andalusī, escrito por Wāsīnī al-A'raŷ. Por otro lado, este trabajo pretende analizar, desde la perspectiva de la mitocrítica, el simbolismo que subyace en el uso del vocabulario dualista del autor argelino.
\end{abstract}

Palabras clave: Novela argelina, hermenéutica, simbolismo, mitocrítica, dualismo, Wāsīn̄̄ al-A'raŷ.

\section{INTRODUCCIÓN}

La esencia del simbolismo artístico como herramienta para trasmitir mensajes que trasciendan a la propia obra ha sido, tradicionalmente, objeto de estudio en materias de carácter más visual, como la pintura o la escultura. A nivel filológico, pese a los diferentes modelos y perspectivas de aproximación al hecho literario que existen, las letras no han sido estudiadas, en tantas ocasiones, desde el prisma de la hermenéutica simbólica.

Pese a todo, como muy acertadamente ilustra Luis Garagalza, esta forma de aproximación a la literatura resulta una herramienta crucial para el estudio crítico de las obras literarias, pues dice:

La hermenéutica es un movimiento filosófico que se centra en el problema de la interpretación. La interpretación ahora se entiende como el modo de ser del ser humano y como el modo de ser de la realidad: si somos capaces de interpretar la realidad es porque la realidad es como un texto o como un lenguaje que pueda ser interpretado. La interpretación y el lenguaje son, por lo tanto, leitmotiv de la hermenéutica. Nuestra contribución tiene como objetivo mostrar la importancia de los símbolos en este contexto ${ }^{1}$.

1 Luis Garagalza, “Tras las huellas de Hermes: la hermenéutica simbólica como contribución a los estudios del imaginario”, Cadernos de Educação, 2014, núm. 48, p. 66. 
Siguiendo esta senda de pensamiento, este trabajo centra su atención en una tarea doble. Por un lado, traducir parcialmente el capítulo primero de una obra imprescindible de las letras argelinas actuales: Bayt al-Andalusī, escrita por Wāsīnī al-A'raŷ o Waciny Laredj. Y por otro lado, este trabajo tiene como objetivo analizar el simbolismo subyacente dentro del marco de la literatura argelina contemporánea desde la perspectiva de la mitocrítica y el simbolismo de los arquetipos, aplicada al uso dual del léxico en la citada obra.

\section{LA RELEVANCIA DE LOS SÍMBOLOS EN LA OBRA LITERARIA}

Las obras de creación no solamente poseen valor literario, lingüístico o fonosimbólico, sino que, además de eso, resulta imposible detraer de la creación su valor intrínseco, la carga simbólica directa o indirecta - incluso a veces inconsciente - que marca la experiencia del creador y del receptor. Pero, ¿por qué es relevante la simbología de una obra literaria a la hora de comprender el mensaje que el autor desea transmitir? ¿De qué elementos se sirve el análisis del simbolismo? Como muy bien especifica Mario Tomé Díez:

La posibilidad de una hermenéutica viene dada por la delimitación y clarificación de dos esferas paralelas: lo que en un principio señalábamos como el mundo del 'logos' y del 'mito', o lo que posteriormente evocaría la presencia de un sentido 'literalı y de un sentido 'alegórico', se podría sinterizar ahora en la actuación de la compresión de la interpretación. Mientras que la 'compresión' se sitúa en el plano epistemológico de la captación de realidades o fenómenos físicos, por vía de la reflexión y del análisis racional; por su parte a 'interpretación' se centra en el plano creativo de las producciones humanas (artísticas, espirituales, mentales), fundamentalmente simbólicas, para llevar a cabo un esclarecimiento de las mismas, no necesariamente por vía racional (inconsciente sugestión, asociación, etc. $)^{2}$.

De este modo, la crítica textual puede comprenderse, ya no desde los planos netamente lingüísticos, sino a través de la hermenéutica simbólica.

En este punto es importante referenciar de nuevo palabras de Garagalza:

2 Mario Tomé Díez, “¿Qué es la mitocrítica?”, Estudios humanísticos. Filología, 1986, núm. 8, p. 134. 
En la hermenéutica el problema de la interpretación comparece en su conexión con el lenguaje y se presenta como un problema universal que afecta a toda nuestra experiencia, a nuestro conocimiento del mundo y a la comprensión de nosotros mismos y del otro [...] Cabría decir que el universo cultural humano es un tejido de palabras, modelos, conceptos, teorías, hipótesis..., es decir, de interpretaciones, que media entre el ser humano y la realidad y en el interior del cual ambos (ser humano y realidad) adquieren configuración y determinación correlativa. Pues bien, la hermenéutica estudia precisamente esa relación interpretativa entre el ser humano y lo real y toma esa relación como punto de partida para hacer un replanteamiento de toda la filosofía ${ }^{3}$.

Así, a través del estudio de la obra desde la perspectiva de la hermenéutica simbólica, es posible aproximarse a la literatura a través del imaginario que el autor crea en la mente del lector:

Puede adivinarse el interés de esta posición para un enfoque de la literatura, ya que si se postula que las imágenes son una revelación de y sobre el inconsciente, el estudio del funcionamiento de lo imaginario va a permitir un enfoque de los textos que no va a consistir ni en el repertorio de los efectos de lo real (el mundo de los fenómenos, en la perspectiva de la filosofía de la referencia o una visión del mundo) ni en la articulación del deseo y el lenguaje ${ }^{4}$.

De esta forma, el cuadro analítico del simbolismo y del mitoanálisis debe estructurarse sobre una dimensión múltiple que ha de estar presente a la hora de analizar una obra literaria desde esta perspectiva de la hermenéutica simbólica. Por definición, el símbolo reviste una estructura de reminiscencia arcaica, se sirve de un sustrato conceptual, ya presente, y conocido por el lector para establecer una metacomunicación que va más allá del mero contenido lingüístico, fonosimbólico o estilístico. La relevancia del símbolo radica en el uso que de él hace el autor para establecer una imaginería que puede abstraerse hasta diferentes niveles de profundidad. En otras palabras:

3 Luis Garagalza, loc. cit., p. 67.

4 Jeant Le Galliot, Psicoanálisis y lenguajes literarios: teoría y práctica, Buenos Aires, Edicial, 2001, p. 199. 
E1 símbolo es el medio por el cual se opera el paso de la vivencia a la palabra y de la palabra al discurso. No solo garantiza la traslación de un estado a otro de profundidad o claridad, sino que, por ser operativo, influye en esta misma traslación ${ }^{5}$.

En un primer nivel de abstracción, puede considerarse que:

El símbolo es el movimiento del sentido primario que nos hace participar del sentido latente y así nos asimila con lo simbolizado sin que podamos dominar intelectualmente la semejanza. En este sentido, el símbolo da, es dador, porque es una intencionalidad primaria que da de manera analógica un sentido secundario ${ }^{6}$.

Sin embargo, se debe tener en mente que la presencia de un símbolo o de una imagen alegórica dentro de la obra literaria general, puede no tener relevancia per se dentro de la cosmología subyacente en las letras. Esto es, el autor puede no haber creado esta simbología con un propósito deliberado. Por lo tanto, para analizar un texto de manera consistente, se debe contrastar más la repetición de símbolos arquetípicos y el contexto donde éstos se dan para poder realizar deducciones generales válidas.

En un nivel de abstracción más profundo, se puede observar como el símbolo puede quedar subsumido en el mito, y todo mito está, a su vez, compuesto por mitemas o subunidades del mito con significado propio. Es este conjunto de elementos mito-simbólicos el que dota de profundidad a la metacomunicación imaginativa de una obra literaria y, por lo tanto, es en este contexto donde se debe aplicar en su totalidad la idea del mitoanálisis como teoría crítica del texto literario. Es decir, el mitoanálisis:

Aspira a desvelar, ya sea en un escritor o en la obra de una época y un medio determinado, los mitos directivos y sus transformaciones significativas. Lo cual permitirá constatar cómo un rasgo de carácter personal en un autor contribuye a la modificación de la 'mitología' reinante o bien acentúa la vigencia de uno u otro mito directivo ${ }^{7}$.

De ahí su relevancia para el estudio del hecho literario.

5 Marie F. Begué, "La Simbólica del Mal de Paul Ricoeur comentada”, Teoliterária, 2012, vol. 2, núm. 3, p. 25.

6 Ibid., p. 26.

7 Mario Tomé Díez, loc. cit., p. 136. 


\section{El simbolismo del léxico duAlista en BAYT AL-ANDALUSİ}

Un vez establecido qué es el símbolo y su papel en la configuración del mito dentro de una obra literaria, la pregunta pertinente sería ¿qué elementos destacables a nivel simbólico pueden detectarse al comienzo de la obra Bayt al-Andalusī de Wāsīnī al-A'raŷ? No hay duda de que se trata de una obra compleja y llena de matices, donde podrían encontrarse elementos susceptibles de ser analizados como relevantes para el estudio simbólico de la obra y para su mitoanálisis. Sin embargo, este trabajo se centra solamente en los elementos recurrentes que poseen un denominador común: la simbología religiosa. Y esto es posible debido a que, desde el mismo comienzo de la novela, es posible observar ciertos marcadores discursivos, donde el acervo cultural y religioso del autor y su forma de comprender el mundo aparecen, a veces de manera directa y en otras ocasiones de forma velada, pero siempre están presentes. De hecho, la extrapolación de la fenomenología religiosa al ámbito literario, es decir, trasladar de una manera tácita a la elaboración literaria los esquemas de pensamiento religioso o espiritual del autor, puede $-\mathrm{y}$, de hecho, lo hace - construir de forma determinante la realidad, el discurrir narrativo y la forma en que se configuran los elementos de carácter espiritual, ciertamente evocadores desde el primer momento, para generar en el lector una serie de imágenes mentales arquetípicas y sibilinas a través de determinados contrastes, como se detalla a continuación.

La frase que abre el capítulo primero de la novela es determinante: "No fue la voz cálida de la llamada a la oración lo que me sacó de la cama aquella noche fría y tranquila, ni el soplo del duro y frio viento invernal que se escapaba de las cumbres de las montañas de Sharia, visibles alli a lo lejos, sino el sonido extraño que escuché proveniente de la puerta del jardín". Aquí es posible observar un patrón que se reproducirá durante todo el desarrollo de la novela: extenso uso de sustantivos y adjetivos y, casi en la totalidad de las ocasiones, contrapuesto entre sí. El dualismo del léxico empleado por al-A'raŷ denota la ambivalencia tanto de los personajes como de la esencia literaria de la obra en general.

Este dualismo léxico, igualmente, viene ligado a elementos religiosos, también muy presentes en la novela. La llamada a la oración es descrita como cálida, y la contrapone al frío viento invernal que viene de las 
montañas. Esta dualidad en la primera escena no es baladí. Como bien expresa Sperber:

Dada una oposición, se encuentran otras que le corresponden. El exceso y la moderación, aun cuando no se trate de cualquier exceso o cualquier moderación, son unas categorías lo bastante generales como para que su oposición se halle realizada en numerosos dominios sin que haya en ello descubrimiento importante. Lo mismo se diga para la mayoría de las oposiciones simbólicas abstractas que se encuentran en la literatura: lo alto y lo bajo, lo frío y lo caliente, lo femenino y lo masculino, la derecha y la izquierda, la naturaleza y la cultura, etc. ${ }^{8}$

Sin embargo, aquí la presencia de esos elementos no es tangencial, sino consustancial. La llamada a la oración representa el mundo ideal iluminado, "cálido" frente al "frío" que es la primera forma en la que el autor describe el mundo real que envuelve a los personajes. Este enfrentamiento entre la voz cálida del ad $a n$ y el frío del viento viene a constituir la cristalización del simbolismo dualista en un mitema que configurará un panorama más amplio dentro del mito general empleado, veladamente, por el autor:

Las distintas variaciones del simbolismo solar son la cristalización de arquetipos de tipo luminoso y ascendente, que se expresan en dualidades antagónicas como 'luz/tinieblas' y 'arriba/abajo'. Todo ello nos conduce por la vía del isomorfismo al esquema de acción que se resume en el verbo 'distinguir' y en el que está implícito ese antagonismo, esa división entre la claridad y la oscuridad, entre la ascensión y el descenso?.

$\mathrm{Y}$ es que este antagonismo dualista se observa en la plenitud descrita más arriba por Tomé Díez cuando al-A'raŷ escribe "me pareció ver cuatro sombras desapareciendo en la penumbra, escurriéndose cuesta abajo por la pendiente que llevaba hacia la carretera numero siete, la principal que iba en dirección al mar [...] Segui a aquellas sombras manteniendo cierta distancia hasta el final de la pendiente, justo antes de que la oscuridad se las tragase por completo". Este fragmente observa la totalidad de la simbología del mitema de los eternos enfrentados. Esto es, el ruido extraño de las sombras -y

8 Dan Sperber, El simbolismo en general, Barcelona, Anthropos, 1988, p. 86.

9 Mario Tomé Díez, loc. cit., p. 145. 
no la voz cálida del muecín - es que lo despiertan, y éstas descienden hacia la oscuridad que acaba por engullirlas, simbolizando el descenso al inframundo que acaba engullendo metafóricamente a estos entes oscuros; como si el destino final de aquéllos que deciden ser sombra fuera, irremediablemente, ser engullidos por el abismo infernal de la oscuridad total. Sin embargo, el descenso por la pendiente los lleva al mar. Este hecho no es baladí. El agua es un símbolo poderoso y sugestivo en tanto configuración teológica de diferentes espiritualidades, y posee una connotación clave aquí: se trata de un simbolismo inmemorial y ecuménico de purificación ${ }^{\mathrm{Io}}$. Una vez más Wāsīnī al-A'raŷ traslada de forma indirecta la fenomenología religiosa al ámbito literario. El mar y el agua como elementos simbólicos de exoneración y renacimiento evocan la redención de las sombras: por mucho que se caiga en la oscuridad, por mucho que se descienda hasta sentir que la oscuridad te "engulle", siempre hay una forma de mantener la esperanza de alcanzar la calidez de la salvación.

El adan o llamada a la oración es también un elemento central en este simbolismo, no solamente por lo mencionado anteriormente, sino por los sentimientos tan intensos que genera en el personaje: "El feroz frío [...] terminó de despertarme de la cabezada mañanera que solía echarme en la cama [después de rezar al alba la oración del fajar], mirando hacia el techo vacio. Ciertamente, la llamada a la oración del fajar emociona, te hace sentir cosas extrañas muy adentro. Me retrotrae a tiempos pasados que han dejado en mi recuerdos y nostalgia. La llamada a la oración tiene en su voz una melancolia particular, cada vez que la escucho siento como penetra en mi, la siento en mis entrañas; en algunas ocasiones la siento como una calidez deliciosa, y otras veces resulta una luz ardiente... la melancolía rebosa nostalgia y miedo a lo desconocido". El personaje busca en el adan, como alegoría de la religión islámica, el lugar de destino al que encaminarse para desterrar de sí la inquietud, la desesperanza y el vacío que siente al quedarse sobre la cama dormido mirando al techo en estado contemplativo. La religión —o más bien la religiosidad como pulsión psicológica para escapar de una realidad desasosegante - le supone hallarse a sí mismo en un lugar diferente, fuera del "frío" que le rodea.

10 Mircea Eliade, Tratado de historia de las religiones, México, Biblioteca Era, 2007, p. 185. 
La construcción del mundo real en el que se desarrollan los personajes continúa oponiéndose a los sentimientos de bienestar que despertaba la voz de la llamada a la oración en el personaje. En relación al entorno, escribe el autor: "Cuando llegué a la plaza giré a la derecha y caminé junto al muro del parque, aunque de parque no le quedaba más que el nombre. Hace tiempo se extendia hasta el final de la carretera". El personaje no ve la realidad desde un prisma positivo, como sí ocurre al hablar del adan; por el contrario, incluso los referentes potencialmente positivos del ambiente que le rodea - el parque como alegoría de la naturaleza, por ejemplolos deconstruye con respecto a cómo eran hace tiempo para enfatizar su visión negativa de la realidad. Asimismo, se refiere en términos similares durante las subsiguientes descripciones de los aledaños del citado parque: "que, pese al tiempo, aún se mantenian pegados en las ruinosas paredes. Algunos carteles colgaban como arañas; otros, medio arrancados, se mantenían adheridos a las farolas".

En consonancia con esta percepción pesimista de la realidad, las paredes son descritas como ruinosas, simbolizando una realidad que se desmorona, que degenera al igual los carteles que colgaban, como luchando por mantenerse en un medio hostil. No es cosa menor, en términos de análisis del simbolismo, la descripción que hace el autor de los mencionados carteles: "algunos carteles colgaban como arañas". La araña es un animal que evoca multitud de imágenes arquetípicas:

En la araña coinciden tres sentidos simbólicos distintos, que se superponen, confunden o disciernen según los casos, dominando uno de ellos. Son el de la capacidad creadora de la araña, al tejer su tela; el de su agresividad; y el de la propia tela, como red espiral dotada de un centro [...]. La destructividad del insecto no hace sino ratificar ese símbolo de lo fenoménico. Por esta causa puede decir Schneider que las arañan destruyendo y construyendo sin cesar significa la inversión continua a través de la que se mantiene en equilibrio la vida del cosmos; así, pues, el simbolismo la penetra profundamente en la vida humana para significar aquel 'sacrificio continuo', mediante el cual el hombre se transforma sin cesar durante su existencia ${ }^{11}$.

11 Juan Eduardo Cirlot, Diccionario de símbolos, Barcelona, Siruela, 2006, p. 88. 
El autor se sirve de estas simbologías para transmitir el mensaje velado de lucha, de eterno construir y destruir de la sociedad en la que se desarrolla la obra.

En este fragmento se aprecia, también, cómo la línea temporal, que se mantiene generalmente en el momento presente del personaje, deja entrever cierta referencia indirecta a un pasado no especificado anteriormente en la novela, desconocido, donde se atisba que la regla dualista positivo/ negativo se mantiene como un hilo conductor que enhebra presente y pasado en un todo sustantivo: pasado/bien versus presente/mal en consonancia con esa referencia reiterada a la melancolía y a la nostalgia que vive el personaje al escuchar la llamada a la oración. De hecho, puede entenderse este fragmento como una interrupción temporal y del espacio - a través de la retrospección que hace el personaje para comparar la realidad actual del parque con la realidad del mismo hace unos añosdonde el autor deja deliberadamente ciertos indicios que expresan la angustia y el vacío existencial del personaje por un momento histórico que no se le ha introducido aún al lector. Es decir, todo lo que rodea al personaje está incompleto, vacío, como si de forma simbólica viera en el mundo el vacío interior que le perturba. Así se puede interpretar de los hechos relatados por al-A'raŷ cuando escribe: "solía echarme en la cama [...] mirando hacia el techo vacio" y cuando escribe "Todas las carreteras estaban vacias". El personaje parece encontrarse en un vacío continuo.

Las referencias indirectas que sugieren una extrapolación de la fenomenología religiosa al ámbito literario en esta novela no cesan aquí. La forma en la que se introduce a otro de los personajes no es cosa menor: "[Entre los carteles] vi a Muah al-Kartil, a quien sus parientes solian llamar al-Hâŷy. El apelativo familiar del político, hâŷy (o aquel musulmán que ha hecho la peregrinación a La Meca) categoriza al personaje de una manera que hace que aparezcan en la mente del lector de forma automática toda una serie de cualidades aplicables al personaje - por la mera connotación del hâŷy o peregrinación - sin que sea necesario que el autor las explicite. Se configura, por tanto, como un personaje religioso que abogaba por una "solución islámica" —en este caso el autor sí manifiesta de forma inequívoca la religiosidad del personaje - a los problemas que acucian a la gente, aunque posteriormente en la novela el personaje evolu- 
ciona y se aleja de estos ideales de moral religiosa. De nuevo, se reproduce esta visión dual de arquetipo de hombre religioso enfrentado a la realidad decadente derivada de la inacción de éste y de su progresivo alejamiento de la moral religiosa. Esta forma binaria de concebir el mundo es una constante en la novela. La realidad del presente está en decadencia por el abandono de la espiritualidad y el consiguiente auge de los fantasmas de la acción humana. Es llamativo, en este mismo sentido, la referencia simbólico-religiosa de la derecha (como ejemplo del bien, de los bien guiados; enfrentado a la izquierda como el mal, los descarriados) que se produce en el primer capítulo de la novela: "Cuando llegué a la plaza giré a la derecha y caminé junto al muro del parque”. De este modo, el personaje principal se presenta simbólicamente como el bien guiado, como el que, persiguiendo a las sombras, es capaz de seguir el camino recto.

En esencia, la obra recoge a través de representaciones simbólicas diversas - ya desde su primer capítulo - el mito virtualmente omnipresente en el imaginario humano: la eterna lucha del bien (representado por los elementos de carácter religioso o espiritual y un léxico de connotaciones positivas) contra el mal (antepuesto al primero por léxico de connotaciones negativas y siempre como contraparte contextual del desarrollo temporal y del desarrollo de los personajes a lo largo de la obra) en un mundo donde la realidad resulta desalentadora (por la propia naturaleza humana que no es capaz de alcanzar esos valores de sociedad idealizada) frente la continua idealización del mundo presentado por la religión, que resulta un refugio tentador donde aliviar la desesperanza.

Todo lo descrito anteriormente puede verse de manera más clara con la lectura de la siguiente traducción parcial del primer capítulo de la obra.

IV. Traducción parcial del primer capítulo de la obra Bayt AL-ANDALUSİ

\section{Capitulo primero}

Encuentro en el golfo de Gurabá

No fue la voz cálida de la llamada a la oración lo que me sacó de la cama aquella noche fría y tranquila, ni el soplo del duro y frio viento invernal que se escapaba de las cumbres de las montañas de Sharia, visibles alli a lo lejos, 
sino el sonido extraño que escuché proveniente de la puerta del jardin. Sali apresuradamente al patio. Me pareció ver cuatro sombras desapareciendo en la penumbra, escurriéndose cuesta abajo por la pendiente que llevaba hacia la carretera número siete, la principal que iba en dirección al mar. Durante un segundo tuve la sensación de que una de esas figuras me era familiar por su forma de caminar renqueante, pero rápidamente eliminé esa idea de mi cabeza. Aprendi a ser cauteloso hace mucho tiempo. Segui a aquellas sombras manteniendo cierta distancia hasta el final de la pendiente, justo antes de que la oscuridad se las tragase por completo. Escuché el ruido de un coche mezclarse con el rumor de las olas de mar, cada vez más fuertes. Fue entonces cuando me di cuenta de que aquellas figuras no parecian ser ladrones: no se giraron en ningún momento; eso me hizo sospechar, pero tampoco quise atacarles.

El feroz frío que venía del oeste del golfo de Gurabá terminó de despertarme de la cabezada mañanera que solía echarme en la cama (después de rezar al alba la oración del fajar), mirando hacia el techo vacio. Ciertamente, la llamada a la oración del fajar emociona, te hace sentir cosas extrañas muy adentro. Me retrotrae a tiempos pasados que han dejado en mi recuerdos $y$ nostalgia. La llamada a la oración tiene en su voz una melancolia particular, cada vez que la escucho siento como penetra en mi, la siento en mis entrañas; en algunas ocasiones la siento como una calidez deliciosa, y otras veces resulta una luz ardiente... la melancolía rebosa nostalgia y miedo a lo desconocido.

\section{$* * *$}

Todas las carreteras estaban vacias. Cuando llegué a la plaza giré a la derecha y caminé junto al muro del parque, aunque de parque no le quedaba más que el nombre. Hace tiempo se extendia hasta el final de la carretera, pero habian utilizado una gran parte de su extensión para construir varias casas y almacenes a lo largo de estos últimos veinte años. Mientras caminaba, alcé mi cabeza espontáneamente y observé las farolas, que parecian interrumpir mi camino de una manera singular. Entonces, pude ver las caras de los candidatos al Parlamento en los carteles, que, pese al tiempo, aún se mantenían pegados en las ruinosas paredes. Algunos carteles colgaban como arañas; otros, medio arrancados, se mantenian adheridos a las farolas. Entre los carteles vi a Muah al-Kartil, a quien sus parientes solian llamar al-Haŷy. El fotógrafo habia borrado las marcas que la viruela habia dejado en su cara. Al-Haŷy cambió 


\section{Antonio Torres Fernández}

su forma de pensar y pasó de defender soluciones islámicas y el libre comercio, a residir en el puerto de la capital, donde esperaba los cargamentos de acero, de cemento turco y de mármol español que traian las grandes empresas chinas, españolas y japonesas. Gracias a ello, controlaba todo el mercado local de la construcción. En un principio, quiso ayudar a su gente, pero pronto descubrió que las cosas no iban a ser así. Se presentó a las elecciones por la circunscripción de Aljazair al-Usta, región que nunca habia conocido en realidad. Sus amigos gestionaron toda su campaña. Decidieron comprar una limusina negra, seguros de que, a ojos de los demás, poseyendo un coche semejante, pasaria de ser alguien de escasos recursos a convertirse en una persona bendecida, capaz de proveerles de buenas cosas. Ya se sabe, algunos necesitan grandes estimulos para decidirse. Bajó con la limusina a varios barrios deprimidos a pesar de los consejos que le daban sus familiares sobre lo peligroso que podria resultar hacerlo. Pese a ello, estaba decidido y llevó su campaña a un barrio donde los musulmanes más creyentes prepararon todo lo necesario. Su barba era el pasaporte de legitimación ante ellos. Una vez alli se dirigió a los presentes y dijo:

-Estoy aqui por vosotros; no me hace falta nada. Dios me dio los bienes que necesito.

Sus compañeros más leales se aseguraban de que la gente se moviera por dos motivos: el soborno o las quejas. A buen entendedor, pocas palabras bastan.

Giré la rotonda y volvi a mi calle. La oscuridad se lo habia tragado todo, incluso el golfo de Gurabá, que antes relucia bajo la luz del sol y se veía el reflejo de los peces y la sombra de color bronce sobre el horizonte. Muchos sentimientos afloraron de repente. Cuando fui a abrir la puerta ese mismo dia me di cuenta por primera vez en mucho tiempo de que la escritura de la pared, en árabe y con algunas palabras en bebreo, se mantenía clara pese a que muchas manos intentaron borrarla sin éxito. Abri el buzón amarillo que estaba colocado en la entrada. Habia una pequeña caja decorada con unas letras en color rosa. Cogi lo que habia dentro... era una carta. Supe por la cubierta que era del ayuntamiento. La miré durante un tiempo y la abrí. Solo lei la fecha, escrita en grandes letras en cursiva. No babia pasado ni un mes desde la última carta que habia recibido. Tal vez fuese algo importante. Se lo comenté a Salim y me dijo que fuese a ver a su amigo Karimo, era un buen hombre y se le daba bien todo.

Me dispuse a entrar a la casa, meti la llave en la cerradura con dificultad y escuché la voz de Sara, llamándome desde el jardín de mi casa. 
- Tio Murad, perdona por importunarte. He oído unas voces y unos movimientos extraños, como cuando huyen los animales de los perros y los cazadores que los persiguen. Fui a mirar por todos lados corriendo, estaba segura de que algo pasaba.

\section{Conclusiones}

Desde una perspectiva de análisis centrada en la hermenéutica simbólica, la obra mantiene una visión de dualismo religioso desde el mismo comienzo, donde se conservan los elementos espirituales como marcadores denominativos de la evolución de los personajes y como elementos centrales en la locución del narrador. El dualismo está presente a través de simbolismo y mitemas tanto en la descripción física de la realidad, como en el plano emocional y psicológico de los personajes, que se mueven entre el ideal moral y la realidad desesperanzadora. Es en este ambiente donde se presenta la riqueza, la política y las malas artes como opuestos a la rectitud y la moral religiosa; elementos centrales de la obra, donde el autor traslada el binarismo, la lucha maniquea entre el bien y el mal que se aloja en lo más profundo de la psique humana, al entorno literario, gobernado por la perspectiva arabo-islámica del ideal moral. En esencia, se puede concluir que el autor construye a través del simbolismo dualista un imaginario basado en los elementos religiosos que expresan la naturaleza fundamental del mito de la lucha eterna entre el bien y el mal. 
114 Antonio Torres Fernández

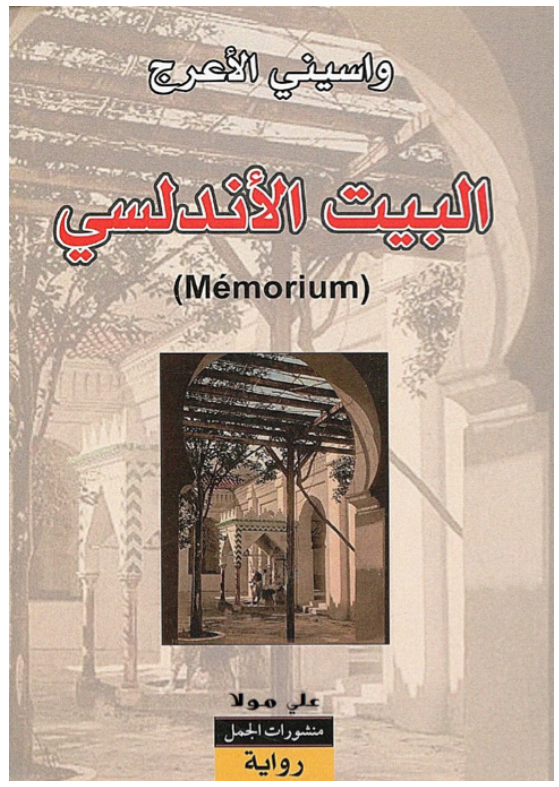




\title{
ARGELIA Y LOS ESTUDIOS ÁRABES EN ALICANTE (III): MARCELINO VILLEGAS
}

\author{
IsAAC DonOso \\ Universidad de Alicante
}

Tras el curso académico 88-89 se jubila la profesora Margarita La Chica, y entra a formar parte del área de Estudios árabes e islámicos de la Universidad de Alicante el prestigioso profesor de la Universidad de Orán Marcelino Villegas: "Para el curso 1987-1988 se ha incorporado como profesor de árabe el Dr. Marcelino Villegas González, anteriormente profesor en la Universidad de Orán (Argelia)".

La emblemática figura de Marcelino Villegas ofrecía al arabismo alicantino la posibilidad de desarrollar la literatura árabe contemporánea, con una vocación crítica rigurosa y un exquisito estilo en traducciones modernas. Era con toda probabilidad una opción académica coherente y ambiciosa, anclada en las Ciencias humanas, que desafortunadamente se apagó con demasiada celeridad. Una delicada condición de salud le produjo un fallecimiento prematuro a la edad de cuarenta y siete años, el i8 de febrero de i99i.

Marcelino Villegas González había nacido el 2I de septiembre de I943 en el norte de la provincia de Madrid, en Lozoyuela. Terminó la licenciatura en Filología semítica en la Universidad Complutense de Madrid en 1968, y el doctorado en la misma universidad en I983. En estos primeros años de formación compartió andanzas con la pandilla denominada «Los Marcianos», de la que recientemente se ha escrito una memoria sentimental:

Marcelino Villegas, nuestro Breton del planeta Marte, filosofaba con lo elemental, con la presencia filmica del cuerpo del actor en el cuadro verídico del fotograma. Y del tiempo, que ha sido siempre en el cine la

1 Míkel de Epalza, "Actividades de la división árabe de la Universidad de Alicante (1986-1987)", en Sharq Al-Andalus. Estudios Árabes, 1987, núm. 4, p. 374. 
medida de todas las cosas, desconfiaba. Su extremismo ontológico me daba una razón más para ser marciano ${ }^{2}$.

Sus inicios como cinéfilo los fue conduciendo hacia la narrativa y la novela, y una verdadera pasión por la ficción. De haber vivido más años, Marcelino Villegas hubiera sido, sin ninguna duda, referente mundial en el conocimiento y crítica de la literatura árabe contemporánea, por agudeza analítica y capacidad de trabajo.

Villegas entró a formar parte de la Universidad de Alicante en I987, habiendo estado previamente en Orán diez años. Conocía bien Irak, donde había vivido un año, y era un gran experto en la figura de Naŷīb Maḥūz. Su tesis doctoral, Prosistas iraquies de la realidad. Una generación: 1945-1958, realizada bajo la dirección de Pedro Martínez Montávez, es una monumental obra de mil trescientas páginas. Fueron pocos los años que Villegas pudo trabajar en Alicante, ya que falleció en I991 frustrándose una excepcional personalidad para el arabismo en la universidad alicantina. Pero en esos pocos años el área de Estudios árabes e islámicos disfrutó de una personalidad singular, cuyo legado y obras son el mejor aval a su reconocimiento perenne ${ }^{3}$.

El año ig88 fue significativamente activo en lo que concierne al crecimiento de la división de árabe de la universidad. Los miembros del consejo de redacción de Sharq Al-Andalus publicaron una buena nómina de obras, se diseñaba la colección de libros esenciales «Xarc al-Andalus» (tras un primer modelo aparecido con Las lenguas prevalencianas, en I986), Naŷīb Maḥfūẓ ganaba el Premio Nobel de Literatura y Marcelino Villegas obtenía la plaza de profesor titular. La obtención del galardón mundial por parte del novelista egipcio catapultó el reconocimiento de la literatura árabe en España. Villegas fue inmediatamente reconocido como el principal especialista español en la figura de Maḥūz y fue solicitado al mismo tiempo por prensa y editoriales. Fruto de estos meses de vorágine fueron títulos como: La obra de Naguib Mahfuz. Ensayo de

2 Vicente Molina Foix, El joven sin alma. Novela romántica, Barcelona, Anagrama, 2017, p. 25.

3 Véanse María Jesús Viguera, “Marcelino Villegas González (1943-1991). In Memoriam”, en Mundo Árabe/Mundo Hispánico: Creatividad e historia. Homenaje a Marcelino Villegas, Madrid, Instituto de Cooperación con el Mundo Árabe, 1993, pp.11-21; y "Fallecimiento de Marcelino Villegas", en Sharq Al-Andalus, 1991, núm. 8, pp. 303-304. 
sintesis (Universidad de Alicante, 1991), y las traducciones Principio y fin de Naguib Mahfuz (Instituto Hispano-Arabe de Cultura, 1988), Dialogadas (1987-1971), de N. Mabfuz (Alianza Editorial, 1988), La ausencia, de N. Mahfuz (Península, 1988), El espejismo, de N. Mahfuz (Plaza y Janés, 1988), El Cairo nuevo, de N. Mahfuz (Península, 1990) y finalmente la emblemática Abdala Benalmocaffa: Calila y Dimna (Alianza Editorial, 199I). A esta nómina de obras y traducciones habría que sumar la también singular obra Picatrix. El fin del sabio y el mejor de los dos medios para avanzar. Tratado de magia y talismanes (Madrid, Editora Nacional, 1982). De este modo, para el inicio de la década de los noventa Villegas se había consolidado como referencia fundamental de la traducción árabe y de la crítica literaria arabística.

Argelia significó probablemente para Marcelino Villegas la gran consolidación profesional a su carrera. Tras una brillante formación en la Universidad Complutense junto a otros miembros de su generación (como Fernando de Ágreda, María Jesús Viguera o Manuela Marín) y bajo la dirección de quien indudablemente ha determinado el rumbo del arabismo moderno español, Pedro Martínez Montávez, Villegas pasó un año en Bagdad (I968-I969) para después ser profesor ayudante en su alma mater hasta 1976. Es cuando finalmente se desplaza a Argelia, donde reside junto a su familia a lo largo de una década, desde el año 1977 al 1987. Trabajará en la Universidad de Orán como profesor contratado, lo que le permite perfeccionar su nivel de árabe hasta acabar adoptando acento argelino: “me sorprendió su tono de buen 'locutor argelino', y le alegró mi calificativo"4.

Lo más importante es que esta labor no fue estéril en generosidad intelectual, en esfuerzo crítico y en producción bibliográfica, que es a fin de cuentas lo que hace perdurar la obra de un hombre. Las personas podrán dejar mejores o peores recuerdos, pero no dejarán de ser recuerdos que morirán con aquéllos que recuerden. La palabra escrita no se la lleva el viento, perdura, y Marcelino Villegas fue un verdadero valiente

4 Así lo señala María Jesús Viguera, loc. cit., p. 13. 
al adentrarse en un tema prácticamente desconocido en la España de su época, y casi también en la nuestra: la cultura argelina de producción árabe. Lo hemos señalado ya en alguna ocasión: a pesar de la vecindad geográfica y cercanía a escasos doscientos kilómetros, se conoce menos en España de la cultura argelina que de muchos otros lugares situados en las antípodas. Es obligación de todos corregir esta anomalía, y Villegas fue el primero que se puso manos a la obra.

En efecto, lo primero que hizo fue traducir la novela argelina en

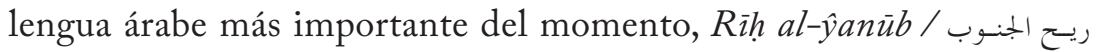
I97I), de 'Abd al-Hamīd bin Hadūga / عبــ الحميــ بـن هدوقــ Abdelhamid Benhedouga. Novela dura, donde el colonizado, después de haber dado la vida en las guerras del colonizador, debe contentarse con un olvidado retiro, en un país que, gracias a la victoria militar a la que ha contribuido el colonizado, seguirá bajo el yugo del colonizador. Dice Abdelhamid Benhedouga:

Tiene él [Ammi-1-hach], sin embargo, un rasgo impar en el pueblo, a saber: que es el único de su generación que participó en la Primera Guerra Mundial y que estuvo a punto de perder la vida en ella: los hados benévolos le salvaron cuando fue alcanzado en la cabeza por la metralla de una bomba de mano. Estuvo adscrito a la famosa línea Le Chemin des dames... Por eso, al final de la guerra obtuvo la licencia para abrir el café, en gran parte por aquella herida ${ }^{5}$.

El viento del sur es sin ninguna duda obra capital de la literatura contemporánea argelina, y tenemos el privilegio de poseer en español la magnífica traducción de Villegas publicada en I98I por el Instituto Hispano-Árabe de Cultura. A la sazón, es prácticamente la única traducción de novela argelina existente en nuestra lengua, al menos entre las grandes obras ${ }^{6}$.

5 Abdelhamid Benhaduga, El viento del sur, traducción de Marcelino Villegas, Madrid, Instituto hispano-árabe de cultura, 1981, p. 128. Véase nuestro trabajo " Enseñándole su lengua a nuestros huérfanos». La expresión en un contexto de intervención lingüística colonial: los casos de Argelia y Filipinas", en Montserrat Planelles, Cristina Carvalho y Elena Sandakova (eds.), De la langue à l'expression: le parcours de l'expérience discursive. Hommage à Marina Aragón, Alicante, Universidad de Alicante, 2017, pp. 295-312.

6 Véase lo que se decía hace veinte años, situación que ha cambiado poco en la actualidad: Luis Miguel Pérez Cañada "Panorámica de los estudios y traducciones de literatura argelina en español", 
Había colaborado en la Revue des Langues de Orán con la publicación de algunos trabajos: "El transfondo árabe de España a través de autores españoles contemporáneos”, 1979, núm. I; “¿Qué es más legal: Yamila o Djamila?", 1983, núm. III; "Una imagen taurina compartida por José Eustasio Rivera y Federico García Lorca”, 1986, núm. VI; y "La araña de la mano", I987, núm. VII. También con al-Qantara y Almenara, con textos de temática argelina como "Le vent du Sud, de A. Benhedouga", Almenara, 1976, núm. IX, pp. 290-291. Pero sobre todo los temas argelinos empezaron a proliferar una vez que Villegas se estableció en la Universidad de Alicante, en colaboraciones con la revista académica del área de estudios, Sharq Al-Andalus. Estudios Arabes. Así es que redacta "Situación de la narrativa argelina", aparecido en 1986, vol. 3. En este texto establece un claro y coherente ideario, enunciado sin complejos, donde la escritura argelina debe ser fundamentalmente en lengua árabe, pues difícilmente lo puede o lo podría ser en la lengua del colonizador:

Pero también puede verse de otra forma: instalado en Francia, escribiendo aún en francés y para una editorial francesa, Argelia ya no es mucho más que un dato mediato en la obra de Muhammad Dib. Y si puede decirse que su estética y su visión del mundo son argelinas, no puede afirmarse otro tanto de las obras que produce, del mismo modo que aunque todo el mundo acepta que el estilo de Luis Buñuel era muy español, nadie mantiene que sus películas fueren, salvo raras y dificultosas excepciones, españolas [...] En definitiva: en un principio se trataba de necesidad histórica; luego, de elección del mundo a que se quiere pertenecer. Cabe predecir que no habrá «narrativa argelina escrita en francés», sino «escritores franceses de origen argelino», y que a partir de ahora es poco probable que escriban en francés otros argelinos que los hijos de emigrantes que hayan optado por la asimilación ${ }^{7}$.

Parece evidente que Villegas entiende el futuro de la producción cultural argelina como necesidad de la expresión de un pueblo, pueblo que debe liberar sus cadenas por medio de la recuperación de la lengua como forma de construir su mundo futuro. Se trata de una visión, diríamos mo-

en Gonzalo Fernández Parrilla, Luis Miguel Pérez Cañada y Rosario Montoro Murillo, Panorámica de los estudios y traducciones de la literatura del Magreb en español, Toledo, Escuela de Traductores de Toledo, 1998, pp. 17-26.

7 “Situación de la narrativa argelina”, 1986, vol. 3, pp. 72-73. 
derna, cuya coherencia y solidez muchas veces es evitada o silenciada por comodidad o intereses de agenda. Para Villegas era evidente el destino cultural del país, por voluntad del mismo, o por la regulación práctica que se había operado en el sistema educativo con la cada vez más notable eliminación de la lengua francesa.

Al mismo tiempo que era necesario descolonizar el futuro de la producción cultural e intelectual argelina, era fundamental reconstruir historiográficamente el decurso natural de la literatura argelina sin asumir irremediablemente las consecuencias drásticas de la intervención francesa. Las tierras colonizadas por Francia poseían una vida cultural que la intervención política modificó, con una intervención lingüística y cultural planificada y agresivamente impuesta. Lo que Villegas señala es la necesidad de dar visibilidad a ese decurso cultural alterado y silenciado por la intervención colonial, de modo que pueda tenerse imagen fidedigna del papel cultural argelino en el contexto de la lengua árabe en el momento de la construcción de una administración política colonial. En ese escenario destaca como autor esencial Aḥmad Rị̣à Hūḥū (I9II-I956), figura cuya restauración supondría, según Villegas, la evidencia de un mundo cultural árabe interrumpido e incluso abortado:

El proyecto de recuperación de Aḥmad Riḍà Ḥụ̣ū tiene una razón que puede llamarse simbólica: afirmar y demostrar que la primera narrativa argelina fue escrita entre Io y I5 años antes de que se produjera la floración de escritores en francés, entre 22 y 27 años antes de la independencia y entre 30 y 35 antes de la publicación de Rìh al-ŷanūb de Ibn Hadūqa, resultando así que la narrativa árabe argelina no sería una recién nacida de apenas 30 años (los primeros cuentos de Ibn Hadūqa, Waț̣ār y Dūdū son de mediados de los años 50), sino contemporánea de la siria y de las primeras obras considerables de la egipcia (Ṭāhā Husayn, Tawfīq al-Ḥakim) y la iraquí (ㅁū n-Nūn Ayyūb, 'Abd al-Ḥaqq Fāḍil) $)^{8}$.

En el número 4 del año I987 de la revista alicantina, publica una pequeña nota, magníficamente resuelta, sobre el arabismo “saitanes" en Los baños de Argel. Hasta ese momento parece que ningún crítico cervantino se había percatado que "saitanes" era arabismo, y Villegas resuelve el entuerto con sobriedad y genialidad:

8 Ibid., p. 73. 
Es decir que, entre 1915 y 1987, la comprensión de esta palabra ha permanecido paralizada. Tanto Jean Canavaggio («término desconocido, a no ser que se trate de una errata») como F. Sevilla y A. Rey («podría entenderse satanes») se escudan en la autoridad de Schevill y Bonilla y, sin buscar más horizonte, repiten su inflexible sabiduría: al considerar exclusivamente que Los baños de Argel es una obra de Cervantes les ha impedido ver que es asimismo una obra de ambiente árabe y musulmán; ello es lo que les ha estorbado relacionar eficazmente saetanes y diablos ${ }^{9}$.

Villegas no tiene ningún reparo en corregir al gran Jean Canavaggio y en adentrarse en temas cervantinos, cuando de lo que se trata es de manifestar "el ambiente árabe y musulmán” que sin duda alimenta la vida y obra de Miguel de Cervantes, "residente" en Argel durante cinco años.

En este mismo volumen Marcelino Villegas publica un artículo igualmente inapelable, la comparación de Bidāya wa nihāya ("Principio y fin", I949) de Naŷî̉ Maḥfūẓ con Rịh al-ŷanūb (I97ı) de 'Abd al-Hamīd bin Hadūga; comparación realizada con enorme brillantez, que va más allá de un ejercicio de análisis prosopográfico o argumental. Como siempre manifiesta la prosa incisiva, breve pero de exuberante riqueza de Marcelino, la idea que subyace en las escasas diez páginas del artículo es de pasmosa brillantez. A saber, para Villegas los personajes creados por Ibn Hadūga son lectores de las obras del novelista egipcio, de esas obras realistas que critican una sociedad desahuciada y gris. Pero precisamente por ese pesimismo de una vida condenada al abismo, el novelista argelino transciende la abulia de los personajes para hacerles tomar posición, actuar, transformar la sociedad para que puedan alcanzar, al fin, el ideal prometido por la revolución social:

Con la nueva irrupción del viento, que representa todo aquello que por naturaleza condiciona a los hombres y que pareciendo definitivo e invencible pasa, se crea un clima espectral y solemne propicio a dejar el ánimo reflexivo, se crea una imagen del fracaso que no es definitivo y puede remediarse, en un párrafo que alcanza una gravedad rítmica de texto sagrado, que se confía y nos confía a lo más que humano con tanta fuerza como la jaculatoria de Bidāya wa nihāya: «El viento habia empezado a removerse y aullar por entre los montes y las colinas del pueblo, y la tierra

9 “Un enigmático término cervantino", 1987, vol. 4, p. 250. 
bañada en luz de luna habia empezado a cubrirse con un sudario de polvo» Rìh al-ŷanūb resulta, pues, una respuesta correctora de Bidàya wa nibāya y puede leerse - partiendo de la escena comentada al principiocomo alternativa y advertencia dirigida a los lectores, cegados quizá, como Țāhir, por el prestigio y la solidez de la obra del novelista egipcio, buena sólo para confundirse si se lee crédulamente o con disposición evasiva. De este modo el escritor argelino propone la reflexión y la lectura inteligente y activa: partir de la realidad y volver a ella; aceptar, asimilar y entroncar con lo adquirido por creadores previos; afirmar la necesidad de nuevas investigaciones desde la base ${ }^{10}$.

Hay que tener una enorme solidez crítica para elucidar con tanta claridad la verdad escondida de las cosas, los argumentos fundamentales, la materia que importa, y prescindir, con el mayor de los desprecios y absoluta elegancia, de todo aquello con lo que mucha gente, de reconocida inteligencia, se entretiene. Marcelino Villegas no perdió el tiempo, no se dedicó a análisis de ocasión ni a florilegios vanos, lo cual es de agradecer, y agradecerle que, en los pocos años que vivió, aprovechara con tanta conciencia y responsabilidad el valioso tiempo del que fue dueño.

Finalmente publica el artículo "Personajes españoles en la narrativa argelina" en el año I989, número 6 de la revista Sharq Al-Andalus. E1 texto vuelve a ser un ejercicio deslumbrante de precisión, conocimiento y agudeza, yendo directamente a los asuntos clave que determinan la presencia del personaje español en un buen número de obras referenciales argelinas. Se trata de obras referenciales, pero no por ello muchas de las cuales siguen siendo a día de hoy desconocidas en España. Villegas muestra una absoluta capacidad de identificar críticamente los materiales y, algo que muchas veces pasa desapercibido, capacidad lectora. En efecto, se da por hecho que tanto el oficio de historiador como de crítico literario presupone una constante acción lectora. Pero nada más lejos de la realidad, mucho de lo que se escribe adolece de lecturas cualitativas y cuantitativas. Hay que leer mucho y bien para poder emitir juicios razonados, y las escasas páginas de los artículos de Villegas tienen tras de sí horas y horas de ese trabajo silencioso, que muchos otros investigadores

10 “¿Influencias o lectura crítica? Naŷīb Maḥūz y 'Abd al-Ḥamīd Ibn Hadūqa”, Sharq Al-Andalus. Estudios Árabes, 1987, vol. 4, p. 89. 
suelen evitarse. De ahí la enorme valía de cada idea verbalizada, como por ejemplo la mención a Idris de 'Alī al-Hammāmī (Aly El-Hammamy, I902-I949) y al personaje del alicantino:

Se metió de aparcero en la tierrita de un español de Alicante recién desembarcado en África. Este español consiguió la ciudadanía francesa de la noche a la mañana y gozaba de todos los derechos gracias al papel sellado de 20 céntimos. Sin demasiadas formalidades adquirió una parcela. Era un borracho que había huido de España de resultas de un robo, varios miles de pesetas a su patrono. Una pequeña fortuna. Gastó parte de lo robado en el terreno, que usurpó a un precio irrisorio y en pagos escalonados a largo plazo; lo demás se esfumó al otro lado del mostrador de zinc de los lupanares de Blida y Argel ${ }^{11}$.

Con todo, puede decirse sin ambages que Marcelino Villegas fue introductor de la literatura argelina en lengua árabe en España, su primer crítico y traductor, y el primer valedor de una realidad cultural que ya por entonces entendía necesariamente arabófona, y cada vez menos francesa. En sus trabajos demuestra un enorme conocimiento literario, fruto tan sólo de numerosas y pacientes lecturas, y de una sin duda magnífica biblioteca. Por fortuna, su colección particular se conserva y es de acceso público como fondo especial de la biblioteca de la Escuela de Traductores de Toledo: "499 monografías dedicadas al estudio de la literatura árabe contemporánea, con particular atención a la argelina" ${ }^{12}$. No existe sección independiente dentro del repositorio, aunque puede localizarse todo el fondo a través del catálogo electrónico: $<$ https://catalogobiblioteca.uclm. es $>$. A continuación, añadimos una pequeña nota descriptiva:

E1 Patronato Universitario de Toledo (en nombre de la Escuela de Traductores) compró la colección a los herederos de Marcelino Villegas. No fue una donación, sino una venta. El contrato de venta está fechado en Toledo el ir de julio de 1996 cuando la Escuela se acababa de crear y era su director Miguel Hernando de Larramendi. La biblioteca estaba compuesta por 822 libros y fue trasladada desde Tenerife, en su domicilio familiar, y a Toledo en 30 cajas. Los libros tratan sobre todo de literatura

11 "Personajes españoles en la narrativa argelina", Sharq Al-Andalus. Estudios Árabes, 1989, vol. 6, p. 106.

12 Véase presentación en la página electrónica de la Escuela de Traductores de Toledo: $<\underline{\mathrm{http}: / /}$ escueladetraductores.uclm.es/biblioteca/> 
(crítica y creación). La mayor parte de ellos son de literatura argelina en árabe, aunque también hay algunos en francés y castellano ${ }^{13}$.

Naturalmente, este fondo existente en la Escuela de Traductores de Toledo representa a día de hoy el principal legado material del trabajo intelectual desarrollado por Marcelino Villegas durante varias décadas. La creación de bibliotecas, como es sabido, representa el origen de cualquier disciplina que sea concebida para avanzar en el conocimiento de un saber. La constitución, preservación y actual catalogación del fondo Villegas, supone de facto el inicio del argelinismo literario en España o, dicho de otro modo, de los estudios sobre literatura argelina. La prematura muerte de Marcelino privó a la bibliografía española - y, seguramente, mundial - de una obra referencial que indiscutiblemente el autor estaba capacitado para realizar, y para cuya redacción tenía el material a la mano, en su propia biblioteca. Por consiguiente, es necesario hacer notar esta situación de la cual la historia nos privó, y valorar el fondo de la Escuela de Traductores de Toledo como el legado de la obra que queda por escribir.

\section{III}

Reproducimos a continuación un listado de obras de temática argelina de Marcelino Villegas. También incluimos un pequeño apéndice iconográfico ${ }^{14}$ con imágenes que ayudan a conocer mejor la obra y el carácter de este investigador, figura fundamental del arabismo moderno español que tuvimos el honor de tener como profesor en la Universidad de Alicante, algunos años antes de que yo iniciara mis estudios en la facultad de letras. Su magisterio perenne lo recibimos a través de su legado, y el retrato que siempre ha presidido el Seminario de Estudios árabes e islámicos de nuestro campus. Aquel retrato enigmático, siempre presente, sirve de recuerdo a las generaciones de arabistas alicantinos sobre el modelo de excelencia. Aunque haga muchos años que ya no esté, Marcelino Villegas

13 Nota redactada y facilitada por la bibliotecaria de la Escuela de Traductores de Toledo, María Luz Comendador, a la que queremos agradecer expresamente su amabilidad.

14 Queremos dejar constancia de nuestro agradecimiento a Fernando de Ágreda por facilitarnos recuerdos de su relación con Marcelino Villegas. Igualmente a Sem y Agar Villegas, quienes han compartido imágenes de su padre. 
sigue impartiendo magisterio en la Universidad de Alicante. Sirva este pequeño texto como muestra de admiración y recuerdo.

Publicaciones argelinistas de Marcelino Villegas

1976. "Le vent du Sud, de A. Benhedouga", Almenara, núm. IX, pp. 290-291.

1981. Abdelhamid Benhaduga: El viento del Sur, Madrid, Instituto Hispano-Arabe de cultura, $216 \mathrm{pp}$.

1986. "Situación de la narrativa argelina", Sharq Al-Andalus, vol. 3, pp. 69-80.

1987. “¿Influencias o lectura crítica? Naŷî̉ Maḥūze y ‘Abd al-Ḥamīd Ibn Hadūqa”, Sharq Al-Andalus, vol. 4, pp. 83-92.

1987. "Un enigmático término cervantino", Sharq Al-Andalus, vol. 4, pp. 249-252.

1989. "Personajes españoles en la narrativa argelina", Sharq Al-Andalus, vol. 6, pp. 103-113. 
126 IsaAc Donoso

ApÉndice iconográfico
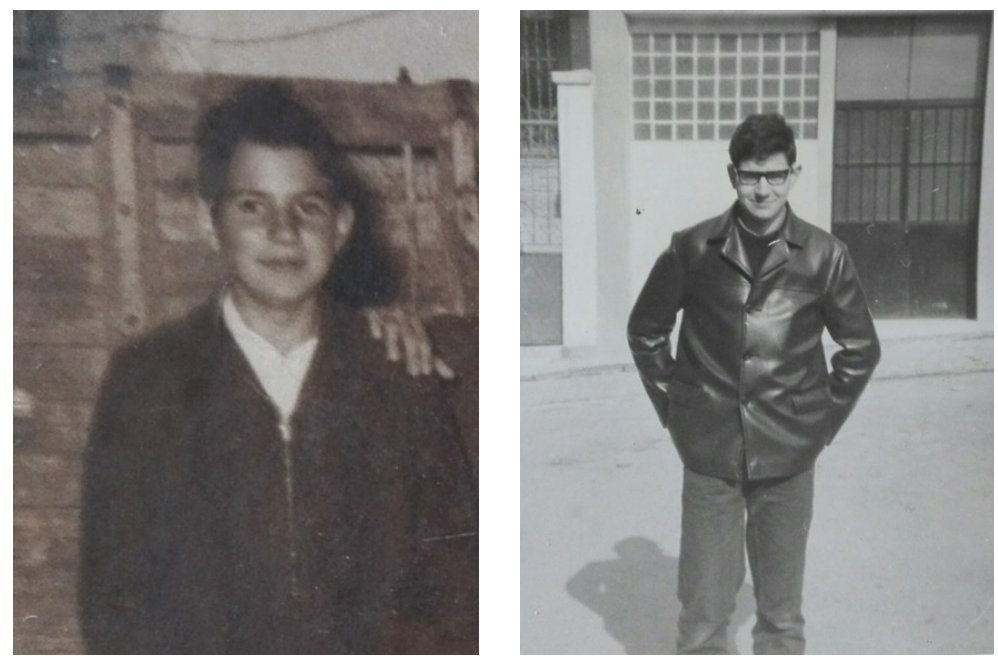

Fotografías de juventud en Madrid

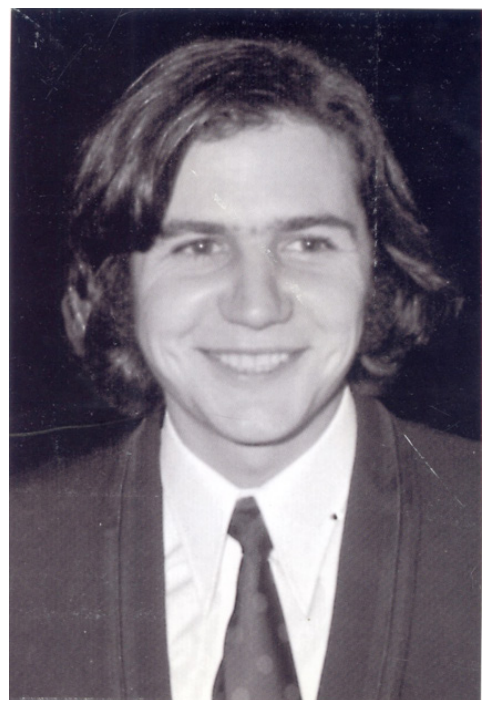

Retrato de Marcelino Villegas en la boda de su hermana María Teresa 


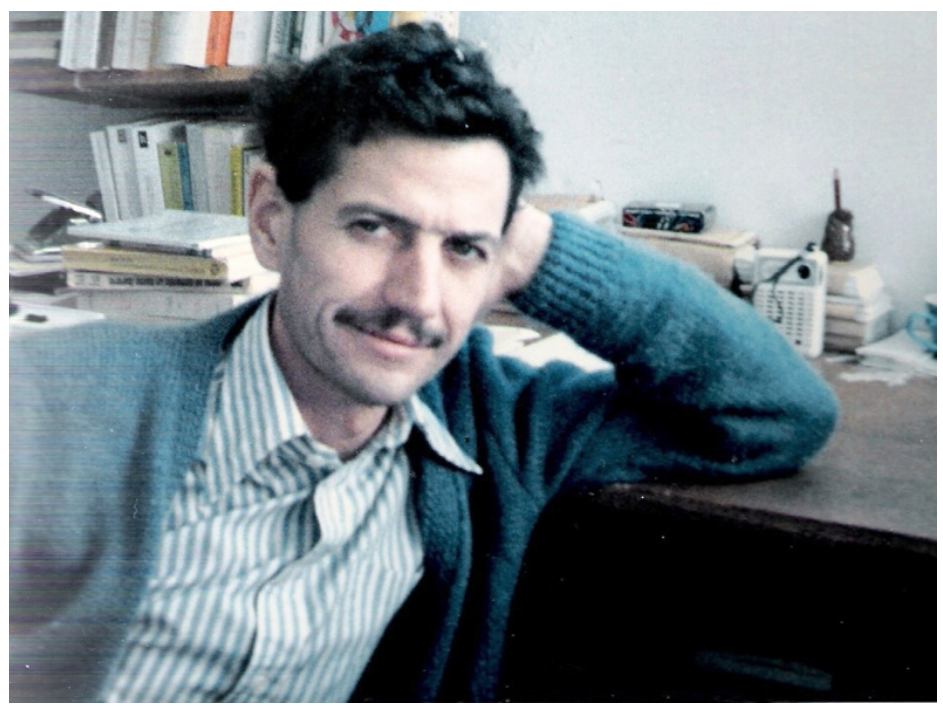

Marcelino Villegas en la Universidad de Orán

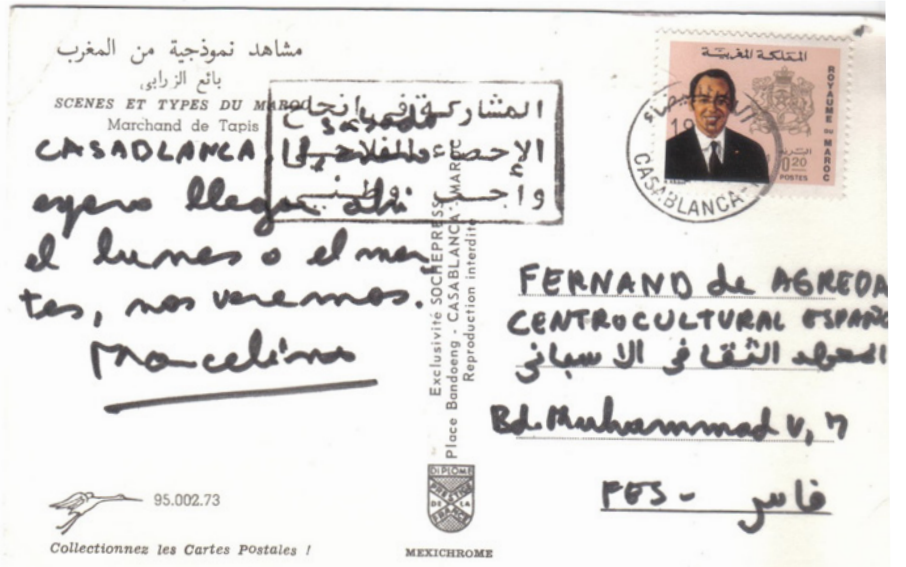

Postal mandada por Marcelino Villegas a Fernando de Ágreda, entonces director de Centro Cultural Español de Fez 


\section{IsAac Donoso}

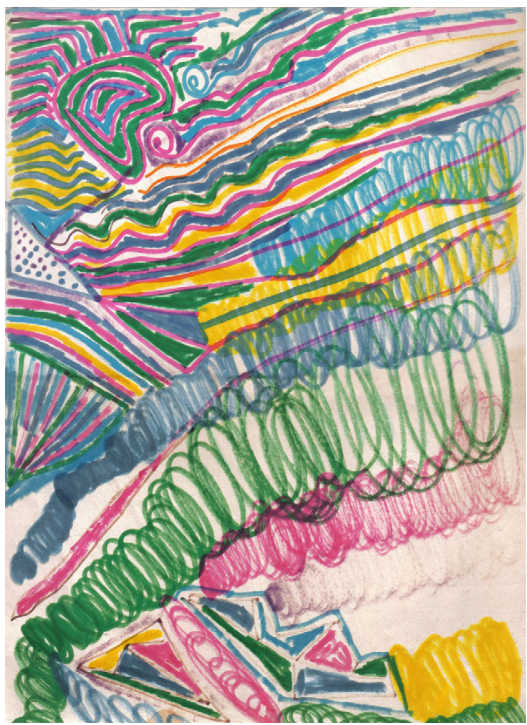

Dibujo hecho por Marcelino Villegas y enviado como regalo a Fernando de Ágreda

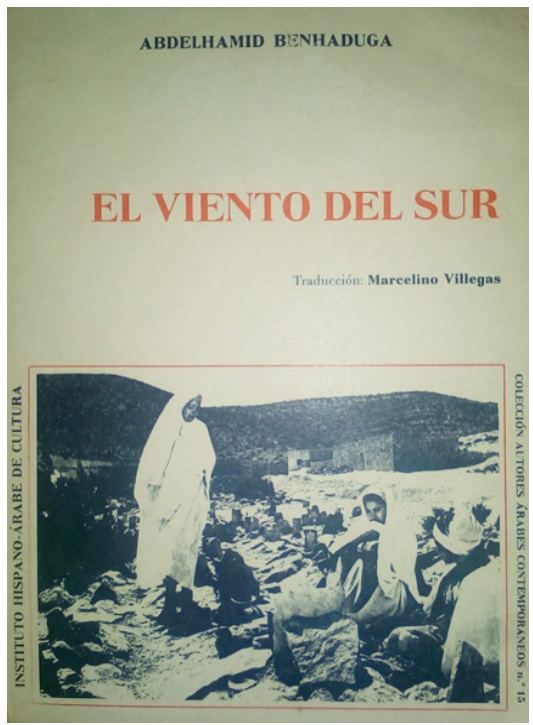

Portada de la novela El viento del sur 


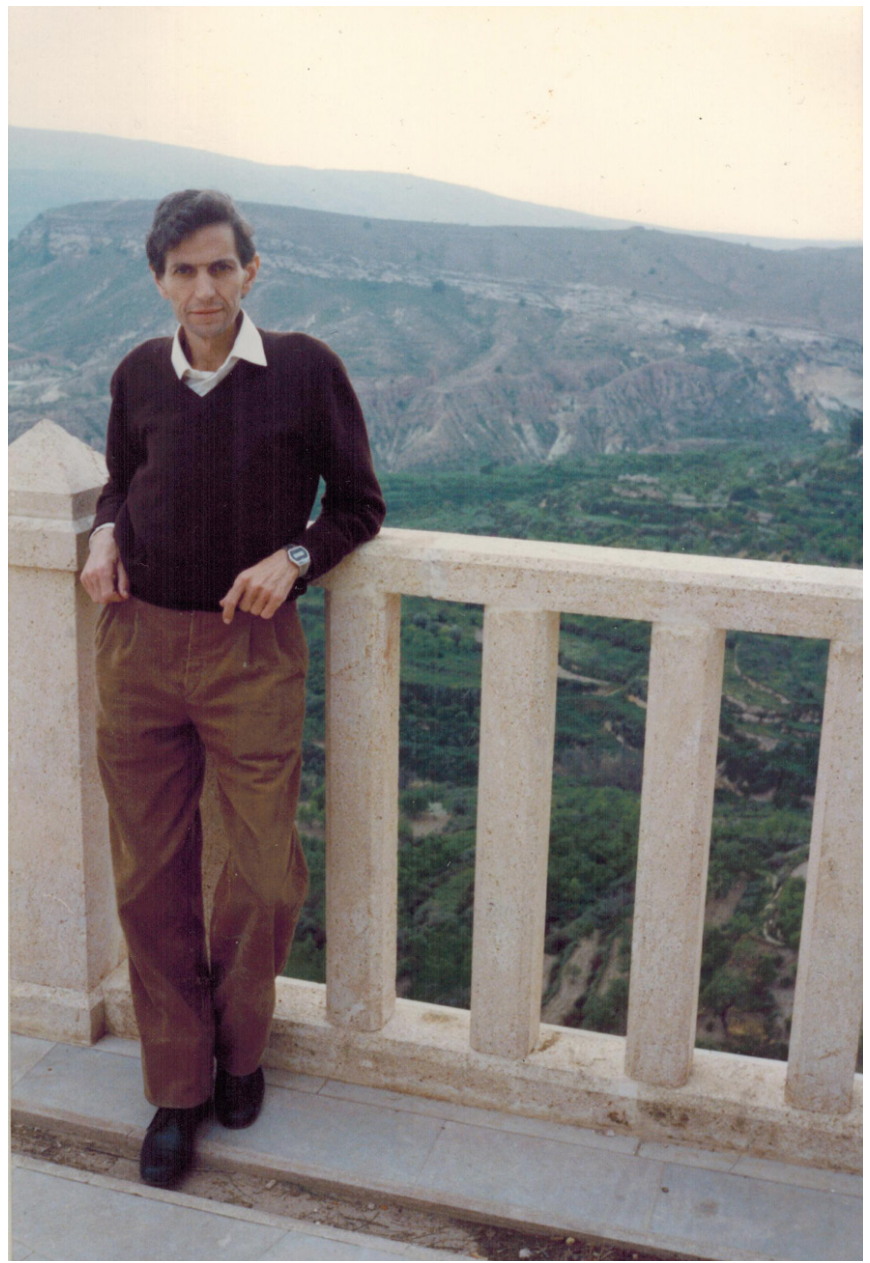

Imagen icónica de Marcelino Villegas realizado por F. Franco Sánchez que preside el Seminario de Estudios árabes e islámicos de la Universidad de Alicante. Fotografía tomada en un mirador de camino a Finestrat 


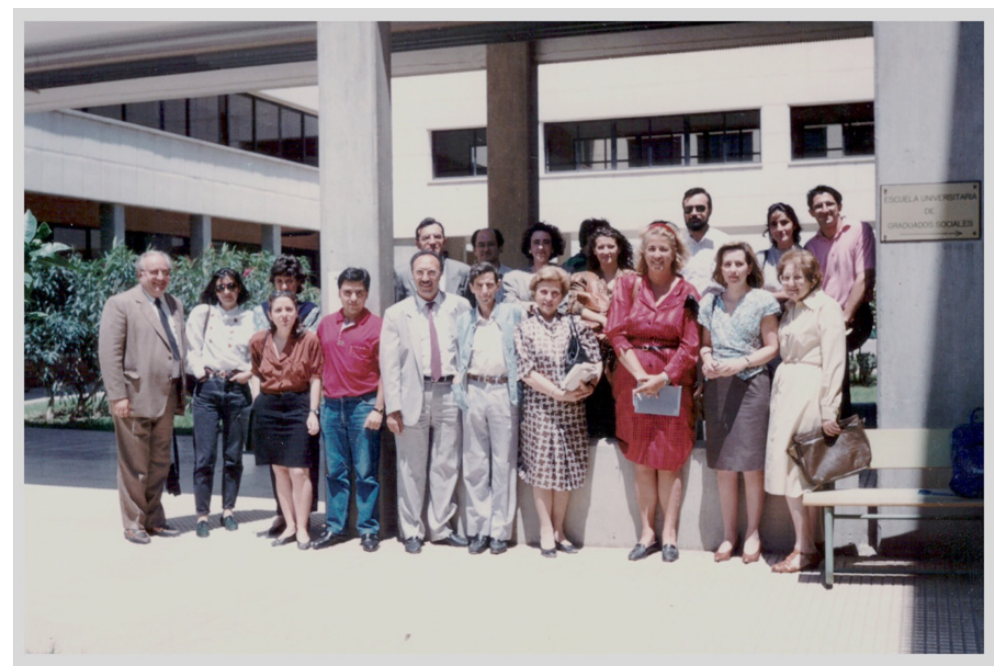

Conferencia impartida por Clelia Sarnelli sobre "Muŷāhid de Denia" el día 29 de mayo de 1990 en la Facultad de Derecho de la Universidad de Alicante, con los miembros del claustro de profesores de Estudios árabes e islámicos y Marcelino Villegas en el centro de la imagen

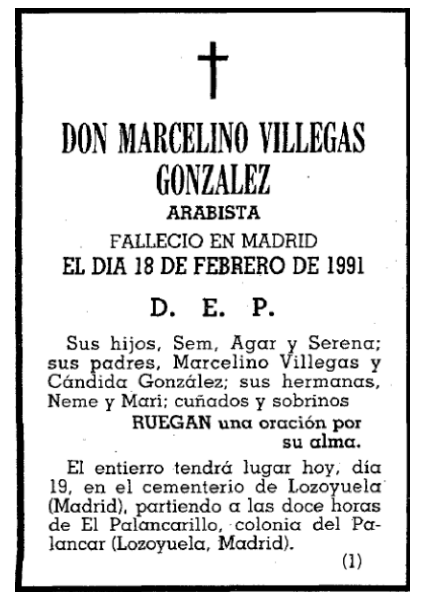

Esquela aparecida en el diario ABC el martes 19 de febrero de 1991 


\title{
CARTA DEL MIQUILACHE SIDI HASÁN (1786): EDICIOON YTRADUCCIÓN
}

\author{
Sarra IKram Hadef \\ Universidad de Alicante
}

\section{DESCRIPCIÓN DEL MANUSCRITO}

Presentamos un ejemplo del uso de la lengua árabe en la época de la presencia del poder otomano en la Regencia de Argel. Se ofrece a modo de ejemplo, edición y transcripción del texto árabe y traducción castellana del manuscrito de Sīdī Hasan, quien fuera ministro de la marina a finales del siglo XVIII. Concretamente se trata de una carta escrita al secretario de Estado español, el conde de Floridablanca, motivada con fines diplomáticos para establecer paces entre ambos países.

El manuscrito se preserva en el Archivo Histórico Nacional de Madrid, con signatura: [A.H.N.M./S.E./ L. 3615]. El documento ha sido reproducido digitalmente por Archivo de la Frontera, proyecto del Centro Europeo para la Difusión de las Ciencias Sociales (CEDCS), bajo la dirección de Emilio Sola, con la colaboración tecnológica de Alma Comunicación Creativa ${ }^{1}$. En dicha plataforma existe breve descripción del contenido del manuscrito: «El miquilache Sidi Hasán al Secretario de Estado español conde de Floridablanca. Argel a principios de yûmäd el awel de 1200 (marzo de I786). Carta relativa a la mediación argelina para firmar la paz entre Túnez y España». La reproducción digital se realiza gracias a los trabajos del profesor Ismet Terki-Hassaine, quien desde hace muchos años lleva investigando brillantemente los fondos documentales españoles ${ }^{2}$.

El presente manuscrito se compone de dos páginas, aproximadamente 46 líneas por página, letra pequeña, apretada y poco cuidada, realizada en tinta negra por mano de un único copista, con sello final. Tiene manchas

1 Véase Archivo de la Frontera, apéndice documental al libro de I. Terki-Hassaine. Fecha de Publicación: 02/03/2012: <http://www.archivodelafrontera.com/wp-content/uploads/2012/03/ Terki-Apendice-doc.-6.pdf $>$.

2 Véase entre otros Documentación española sobre Argelia: ocho legajos del Archivo Histórico Nacional de Madrid sobre las relaciones hispano-argelinas, 1767-1799, Universidad de Orán, tesis DEA, 1980. 
de humedad que no impiden su lectura. La carta la dirige Ḥasān wakìl al-järiŷ/ وكيل الخارج, título del comandante de la marina y relaciones exteriores. En torno a este título, hay que decir que la castellanización de este arabismo se realiza en la forma de "miquilache" desde la lingua franca hablada en Argel, ya en tiempos de Alonso Cano:

Sigue à este en dignidad el Bechiel Arge, que en franco llaman vulgarmente Miquilache, cuio cargo ès la suprema yntendencia de quanto pertenece al Puerto, y la Marina: su primera institución solo fuè deun simple guarda Almagacen, pero deun siglo à esta parte ha hido poco à poco incorporando las facultades de Yntendente, y de Almirante, que exerce por un theniente, $y$ dela puerta dela Marina afuera, ès en el puerto, y la mar lo que el Aga de moros en la tierra, Es desu cargo el equipar los armamentos para los corsos, la construccion, y conservacion delos vasos, y toda la economia del Puerto, y la Marina. En consequencia de esto, todos los negocios delas potencias Christianas dependen en gran parte deèl; Por lo que todos los consules y mercantes procuran grangearse su benevolencia mas que la de otro algun Ministro, y que la del mismo Bey, cuias exacciones y regalos son sus principales emonumentos ${ }^{3}$.

La edición de manuscritos árabes en España ha venido realizándose en su gran mayoría por cuestiones prácticas, es decir, el arabista tenía que conocer el contenido, y por ello hacía un trabajo de edición y traducción. Pero lo cierto es que la edición puede constituir un fin en sí mismo, también en términos lingüísticos.

A continuación, ofrecemos aquí un breve ejemplo con el fin de ensayar unas pautas propedéuticas. En primer lugar mostraremos el texto en la lengua de origen, que es el árabe con ciertos giros dialectales; luego transcripción y, finalmente, traducción literal del contenido en lengua española. Respecto al modo de transcribir las palabras árabes, se indicarán las vocales largas de la siguiente manera: $\overline{\mathrm{a}}-\overline{\mathrm{i}}-\mathrm{u}$. El articulo /al/ se elimina de los nombres. Empleamos de forma general el siguiente sistema de transcripción:

3 José Miguel Escribano y Ricardo Castillo Larriba, Argel Delenda Est. E1 "Nuevo Aspecto de la Topografía de la Ciudad y Regencia de Argel" de Fray Alonso Cano y Nieto, en Archivo de la Frontera, 2010, pp. 70-71: <http://www.archivodelafrontera.com/wp-content/uploads/2010/03/ GFUENTES-02.pdf> 


\begin{tabular}{|c|c|c|}
\hline$\varsigma^{\prime}$ & $j z$ & ق ق \\
\hline$ر r$ & S س & s) $\mathrm{k}$ \\
\hline$ت t$ & S ك & 1 \\
\hline$ث \underline{\mathrm{t}}$ & & pm \\
\hline ج $\hat{y}$ & dب ض & $\checkmark n$ \\
\hline$\tau^{h}$ & b t & o $h$ \\
\hline$\dot{\mathrm{c}} \mathrm{j}$ & Z & $g W$ \\
\hline $2 \mathrm{~d}$ & $\varepsilon^{\prime}$ & لا ي \\
\hline$\dot{j} \underline{d}$ & & ف \\
\hline
\end{tabular}

II. EDICIÓN

$$
\text { الحمد لله و لا حول و لا قوة الا بالله }
$$

من عند ربّهُ سبحانه المتو كُل على الله في جميع اموره

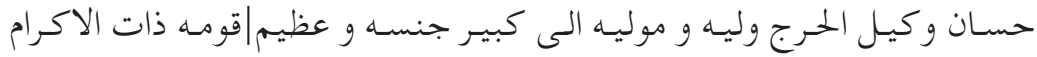

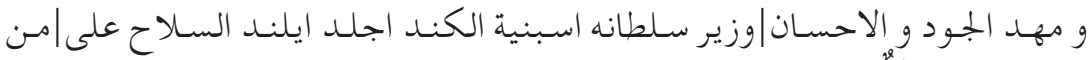

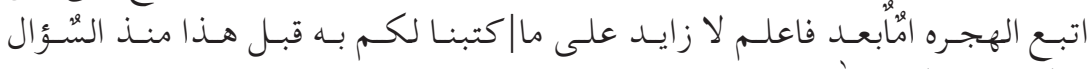

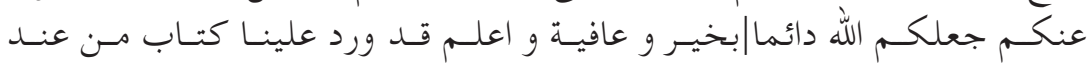

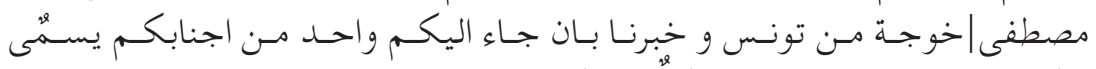

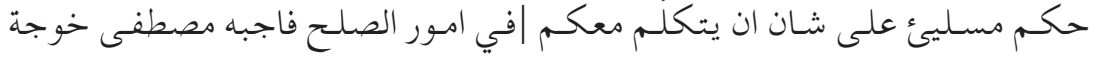

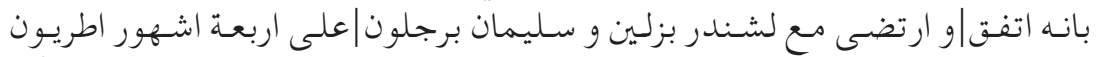

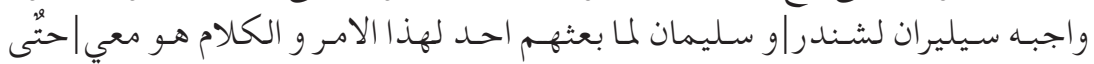

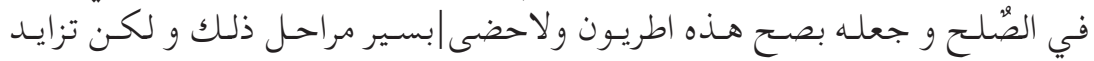

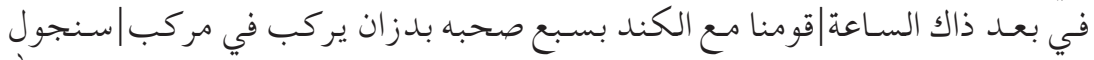

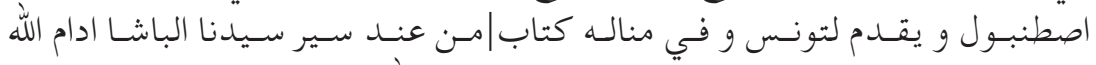

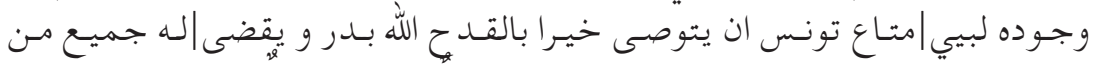

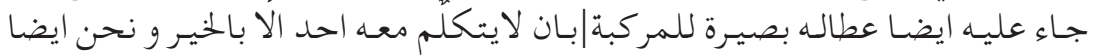

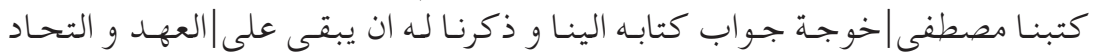

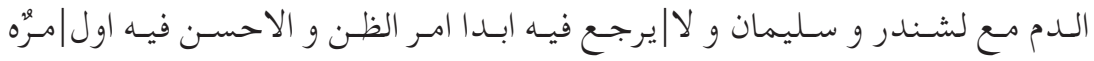

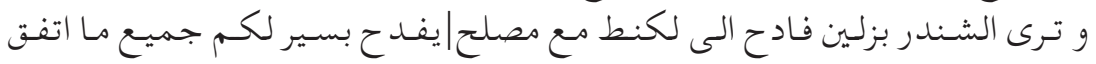




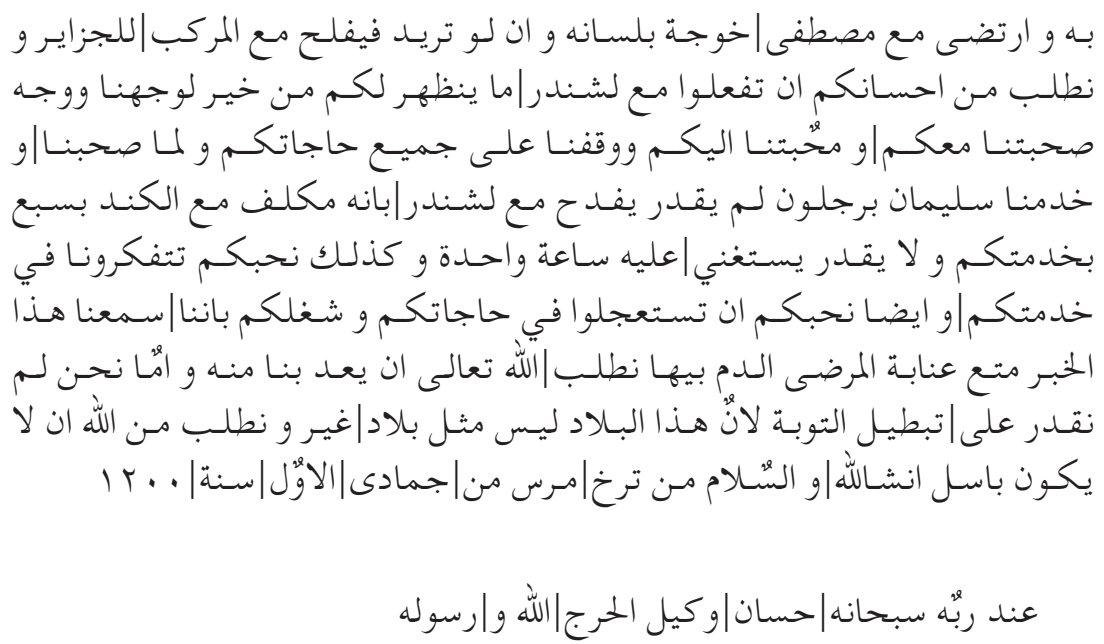

\section{TRANSCRIPCIÓN}

Al-Ḥamdu lillah wa lā ḥawla wa lā quwata ilā billah

Min 'ind rabb-ih subḥana-h al-mutawakkil 'alā Allah fì ŷamī‘ umūrih

Hasān wakīl al-ḥaraŷ walīh wa mawlīh ilā kabīr ŷinsih wa 'aẓīm qawmih dِāt al-'ikrām wa mahd al-ŷūd wa al-'ihsān wazīr sulțānih isbaniya al-Kand Aŷlad Īland al-silāḥ 'alā man 'itaba'a al-hiŷra ammā ba'd fa'lam lā zāyad 'alā mā katabnā lakum bih hadēā mundu ssu'āl 'ankum ŷa'alakum Allah dā'iman bijayr wa 'âfiya wa 'lam qad warada 'alaynā kitāb min 'ind Muștafā Jūŷa min Tūnas wa 'ajbara-nā bi'an ŷā'a ilaykum wāḥid min aŷnābikum yusammā Hakam Maslì 'lā šān an yatakallam ma'akum fī umūr al-ṣulh faĪaŷabah Muștafā Jūŷa bi'anna-hu'tafaqa ma'a-h wa rtad̄ā ma‘a Lašandar Bazlīn wa Sulaymān Barŷlūn 'alā' arba'at ašhūr Ațriyūn wa lāḥad̄ā bisayr marāḥil dِalik wa lakin tazāyada fì ba'd d̄āk al-sāa qawmu-nā maā al-kand Basba‘ șaḥbah Badzān yarkab fī markab Sanŷūl Ișțambūl wa yaqdam li Tūnas wa fī manālih kitāb min 'ind sayr sūdnā al-Bāšā adām Allah wuŷūda-h lïbīy Mtā'Tŷnas an yatawașā jayran bi al-qaḍ̣ Allah badr wa yaqụ̂i la-h ŷamī' man ŷà ' 'alay-h ayḍan 'țāla-h baṣīra lilmarkaba bi'an lā yatakallam ma'a-h aḥad illā bi al-jayr wa nạ̣nu aỵ̣an katabnā Muștafā Jūŷa ŷawāb kitābi-h ilay-nā wa ḍakar-nā an yabqā 'alā al-'ahd 
wa al-tihād al-dam ma‘a Lašandar wa Sulaymān wa lā yarŷa‘ fîh avadan amr al-ẓan wa al-aḥsan fīh awal marra wa tarā al-Šandar Bazlīn fādị̣ ilā Lcant ma‘a Muṣlị̣ yafdạ̣ bisayr lakum ŷamī‘ mā itafaqa bi-h wa irtaḍ̄a ma'a Mușțafā Jūŷa bilisāni-h wa an law turid fayaflạ̣ ma'a al-markab fî al-Ŷazāyar wa naṭlub min ihsānik-um an taf'alū ma'Lašanar mŷ yanḍahir la-kum min jayr liwaŷhi-nā wa waŷhi șuḥbati-nā ma'ak-um wa maḥabbati-nā ilayk-um wa waqaf-nā 'lā ŷamī' hāâātik-um wa šuğlikum bi'anna-nā sami'-nā haḍā al-jabr fī 'Anāba al-marḍā al-dam bī-hā națlub Allah Ta'ālā an ya'id bi-nā Minh w ammā naḥn lam naqdir 'alā tabțîl al-tawba li’ana had̄ā al-balad laysa mițl bilā gayr wa naṭlub min Allah an lā yakūn bāsal inšā Allah wa ssalām min taraj mars min ŷumādā al-'awwal sant 1200

\section{Traducción}

Alabado sea Dios, no hay ni fuerza ni poder excepto Dios

El esclavo de su Dios glorificado sea él, Hasān quien pone la fortaleza de Dios en todos los asuntos de la caridad, el secretario de Estado, su príncipe y su jefe.

Estimado el grande, el genial para su gente, el honor, el hombre de la bondad y caridad, el ministro de su rey español el conde Aŷlad Iland [Floridablanca], la paz sea con los que viajan y migran. Sepa V. que no hay novedad desde la última carta que le remitimos, y que Dios siempre les haga bien. Sepa V. que recibimos una carta por Mușțafā Jūŷa desde Túnez, nos ha informado que ha llegado uno de sus hombres, llamado Hakam Musalī’ para que hable con ustedes sobre la paz. Muṣțafā Jūŷa le ha respondido que estaba de acuerdo con él y satisfacía con Lašandar Bazlīn [Alejandro Baselini] y Sulaymān, cuando les envió a alguien hace cuatro meses, y doy mi palabra de honor que lo que digo es verdad. Continúa por este camino, pero se exagera con nuestra gente en estos momentos. El amigo del conde Saba' Yadzān se ha instalado en el barco de Sanŷūl de Estambul para llegar a Túnez, teniendo una carta enviada por nuestro pachá — ique Dios sostenga su vida! — al bey de Túnez para 
dialogar positivamente con la presencia de Dios y ponerse a su servicio. Todos los que van con él en el barco son gente de bien. Nosotros, también, hemos escrito a Muḥammad Jūŷa la respuesta de su escrito y no ha mencionado que vaya a mantenerse en el pacto y la unión de sangre con Lašandar y Sulaymān, y no tiene dudas de ser fiel. Por vez primera va a ver que Alšandar Bazlin viaja hacia Lakanț [Alicante] con un consejero que tiene dispuesto todo lo que ha sido acortado, y tiene tratados con Muștafā Jūŷa en su lengua. Si quisiera, va a ir con el barco a Argel. Pedimos a su magnífica persona que haga todo lo necesario para que esté bien con Lašandar, por respeto a nuestra cara y la cara de nuestra amistad y mostrar amor a ustedes. Estamos firmes a cualquier necesidad. Cuando hemos creado la amistad y hemos ayudado, Sulaymān Barŷalūn, no ha podido alcanzar a Lašandar, al que confiaba fiel. Queremos también dar pronto término a sus necesidades y sus trabajos. Leemos esta carta en 'Anāba debido a una enfermedad sanguínea. Nos refugiamos en Dios, pero nosotros no podemos dejar el arrepentimiento porque este país no es como otro país y pedimos a Dios para no sea una enfermedad contagiosa ¡Ojala! Y un abrazo nuestro.

Fecha de marzo correspondiente a ŷumādā al-awwal de I200.

Su amigo el esclavo de Dios — glorificado sea_, Hasān, ministro de Estado, siervo de Dios y su Profeta.

\section{Traducción del documento N. ${ }^{\circ} 272$ Legajo n.o 3615}

Copiamos a continuación el documento número 272, legajo número 3615, tal y como lo transcribe el profesor Ismet Terki-Hassaine en su DEA defendido en la Universidad de Orán en I980 con título Documentación española sobre Argelia: ocho legajos del Archivo Histórico Nacional de Madrid sobre las relaciones hispano-argelinas, I767-I799, pp. I44-I46. Se trata de versión castellana realizada por el trinitario Alonso Martínez González, de este mismo documento, o un documento de muy similares características. A pesar de nuestra búsqueda en el catálogo informático "PAres. Portal de archivos españoles», no hemos logrado encontrar la signatura 3615 y el contenido concreto del expediente. Será necesaria una consulta in situ para identificar los documentos vinculados al expediente, 
y las circunstancias de la redacción del presente manuscrito. En cualquier caso, y dado el precioso e ingente trabajo que el profesor Terki-Hassaine ha puesto a disposición de la investigación, creemos que es relevante reproducir este documento a expensas de futuros estudios.

Alabado sea Dios todo poderoso: Del criado que adora a Dios Maravilloso, y que solamente fía en su providencia, conformando en todo con su voluntad adorando piadosa y devotamente al Altísimo y uno solo, Asen, el Migaleche, al magnífico de su gente y Grande en su nación, mi cordial y verdadero amigo el Ministro del Rey de España el Conde de Floridablanca, salud a quien sigue el derecho camino. Participamos a vuestra Excelencia el recibo de su estimado el Conde de Expilly, y la que habiendo leído y entendido su contenido he tenido grande gusto con ella y no he dado pronta respuesta esperando aviso de la comisión que habíamos enviado al ministro del Bey de Túnez Achí Mostafá Jocha con nuestros amigos y estimados como nuestros hijos Solyman Alveguerín y el Capitán Alejandro Baselini para que viniese a mi mano el orden para tratar una paz amistosa en esta de Argel con vuestro enviado el Conde de Expilly. Y luego que me ha llegado la respuesta, he avisado al padre del Hospital que sabe hablar y entiende el árabe para que la traduzca fielmente, con sello y mi firma la acompaño a V.E. con ésta mía. Tengo encargado al enviado de Túnez a esta Regencia con el regalo acostumbrado de todos años que diga al Bey que no se descuide en la paz de España de cuando le tengo prevenido, y para mayor seguridad, hemos enviado al turco Cherif nuestro amigo y del Conde de Expilly para que quede allí y los mantenga en lo que han establecido Solyman y Alejandro hasta que V.E. dé órdenes.

Este Alejandro es mi especial amigo desde que estuve en Cartagena cuando me apresaron viniendo de Constantinopla, pues cuando me soltaron me condujo a su casa sirviéndome en un todo a quiere boca, de modo que le debo para siempre una verdadera obligación y con estos motivos me deje de servirlo cuando ha estado bajo el dominio de otra nación, más ahora que ya se halla español quisiera que V.E. le colocara 
en el número de sus servidores. Solyman Alvequerín, nuestro amigo, y como hijo desde que el Conde de Expilly entró en Argel le ha servido siempre en cuanto le ha ordenado muy pronto y muy fiel como el mismo Conde podrá informar.

V.E. dígame en qué podré agradarle para desempeñar mi obligación en que me ha puesto la fineza con que me ha favorecido de parte del Rey su amo por mano del Conde de Expilly, de lo que repito muchas gracias pidiendo a Dios que guarde su vida muchos años.

Argel en 24 de jumed el auel de I200 ó 26 de marzo de I786.

Traducida fielmente del árabe al castellano a instancia de Sidi Hassán, el Migaleche por mí.

\section{Nota LingüísticA}

Con el transcurso del tiempo, la lengua árabe ha sufrido cambios a través del devenir de sus hablantes. Durante la regencia otomana, el uso de la lengua árabe fue quedando relegado de los estamentos oficiales y normativos de la región. Los sultanes turcos solían usar vocabularios dialectales de una región conquistada con el uso de numerosos préstamos. Todo ello hace que el contacto lingüístico modifique la lengua, en casos como: zāyda por ziyāda "aumentar"; jabarnā en árabe clásico por ajbaranā, "no ha informado", ašhür por ašhur, "meses"; al-tihād, por al-'ittihḥād, "la unión"; tarij por al-tārīj, "la fecha”; wakīl por jādim, "ministro"; șahba-h en lugar de șạhibu-hu, "su amigo", 'alā šān en árabe clásico por likay, "para que”; mtā', proposición "de”, etc. El lenguaje islámico constituye una parte gráfica destacada. Los turcos también lo usaban como imperio islámico en la época. El autor aplica el lenguaje islámico en expresiones religiosas para introducir y concluir la carta, como Al-Hamdu lillab wa là hạwla wa là quwata ilā billah, Min 'ind rabb-ih subhana-b al-mutawakkil 'alà Allab fì yamì'umürih, al-Hamdulillah, etc. 


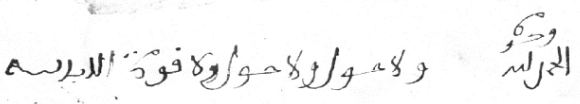

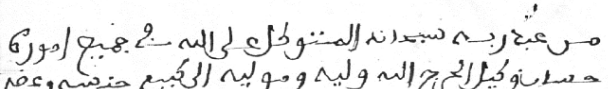

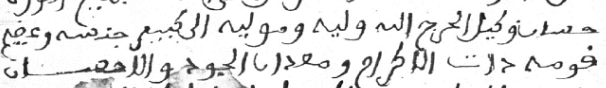

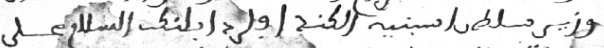

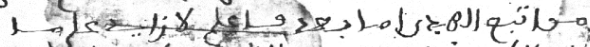

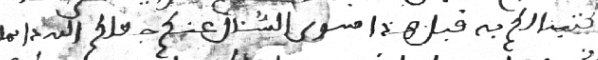

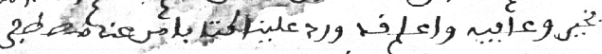

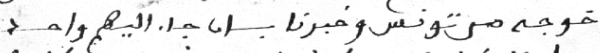

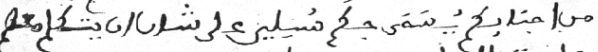

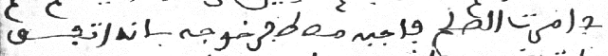
Gel

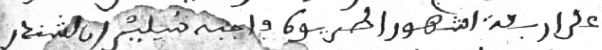

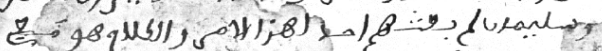

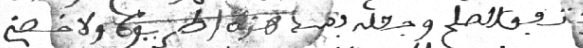

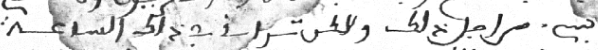

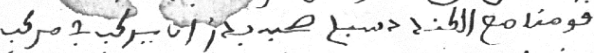

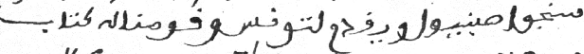

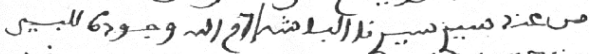

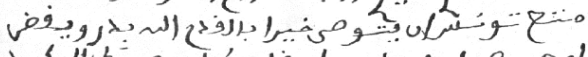

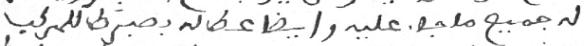

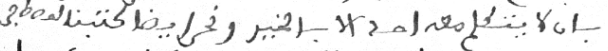

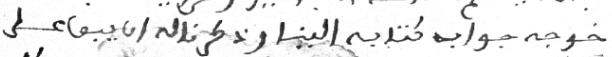

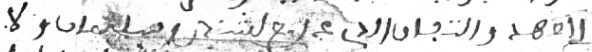

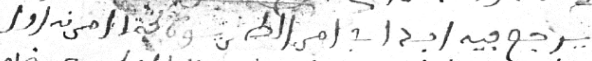
ए. 
140 Sarra IKram Hadef

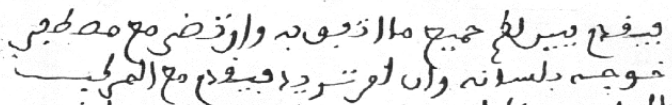

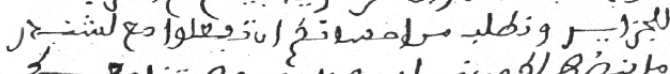
و

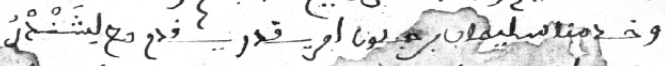

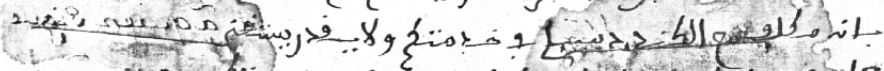

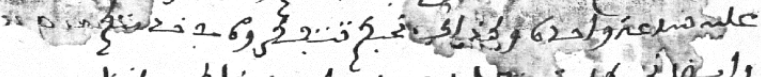
bi) flisg با.

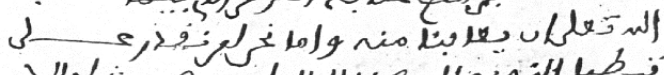
ف غبر

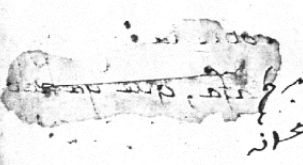

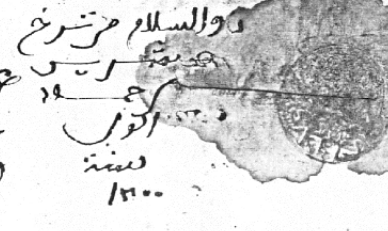

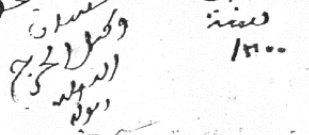




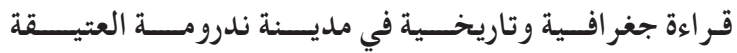 APROXIMACIÓN GEOGRÁFICA E HISTÓRICA A LA CIUDAD DE NEDROMA}

بن زغادي محمد تلمدان

جامعة تلمسان

Muhammad Ben Zagadi

Universidad de Tremecén

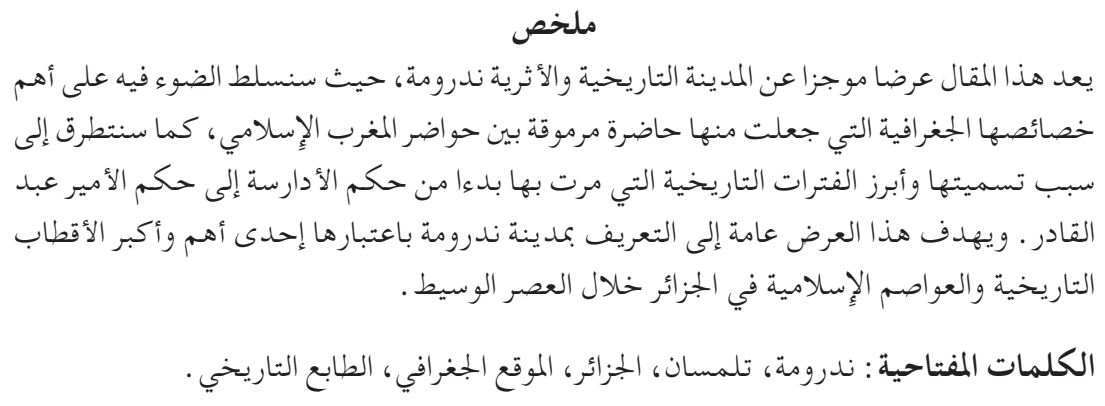

\section{Resumen}

Introducción a las características geográficas del entorno de la ciudad de Nedroma, y su vinculación histórica con Tremecén, capital política y cultural de la región. Se describe de forma preliminar la geología, la hidrología y el terreno donde se ubica la actual medina de Nedroma. En el segundo punto, se relatan los hitos más importantes de cada periodo histórico desde los orígenes hasta la época del emir 'Abd al-Qādir, con una pequeña nota sobre la etilomología de la localidad. El objetivo del presente trabajo es resaltar la importancia de Nedroma en la historia del occidente argelino, y su valiosa ubicación geográfica.

Palabras clave: Nedroma, Tremecén, geografía de Argelia, historia de Argelia. 
إن دراسة جغرافية وتاريخ المدن يساهم بشكل مباشر في إبراز الوجه والعلاقة المتبادلة.

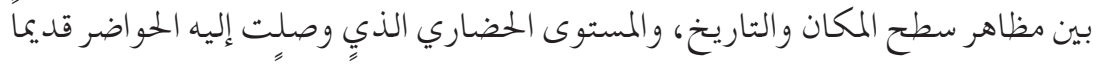

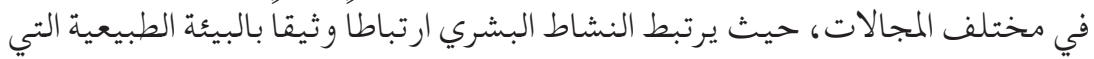

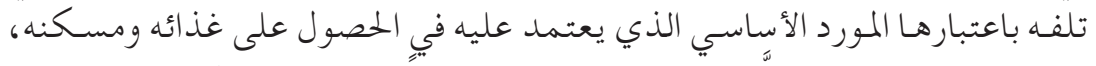

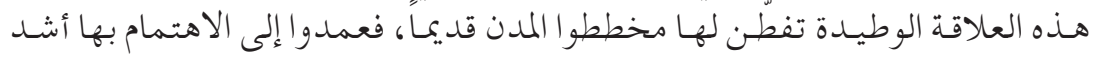

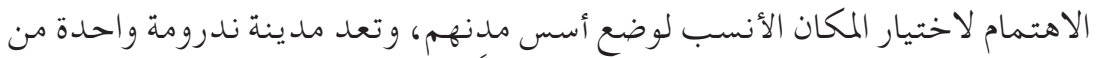

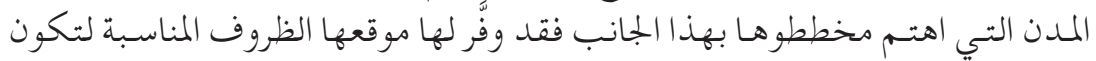

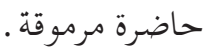

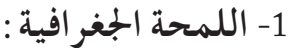

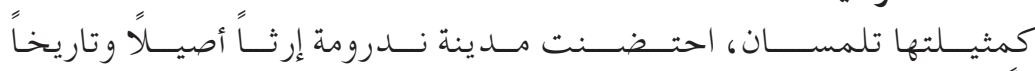

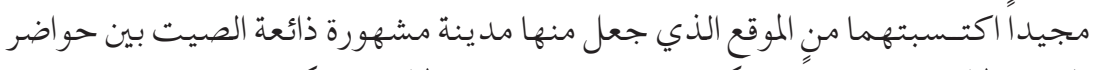

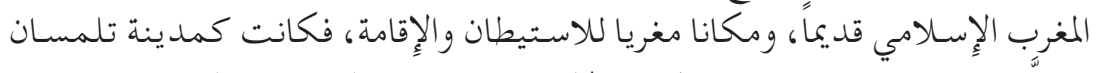

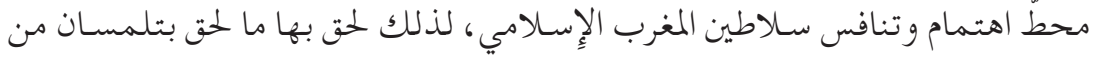

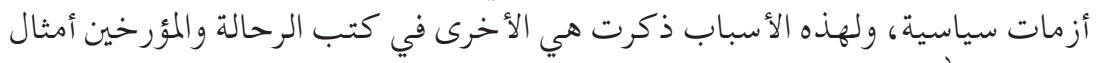

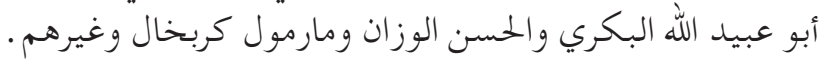

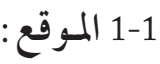

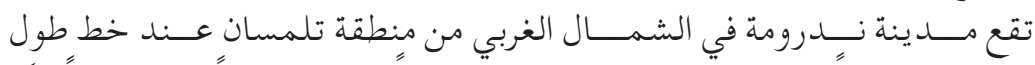

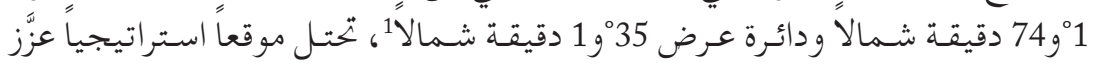

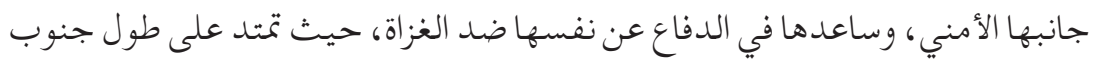

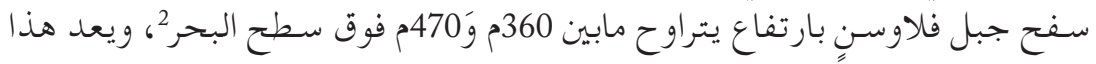

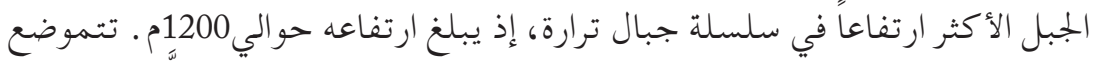

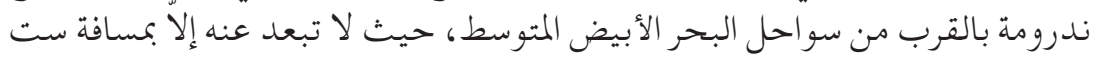

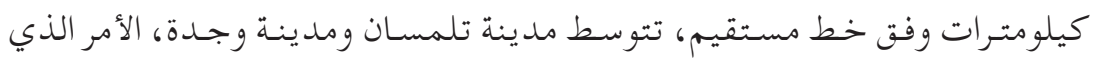

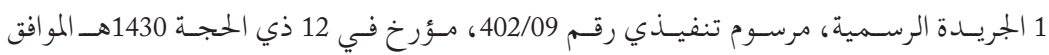

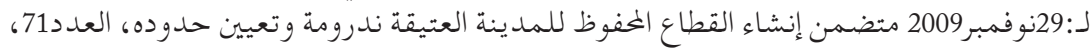
الجزائر2009، ص:

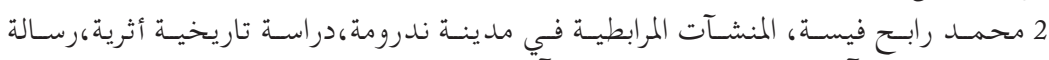

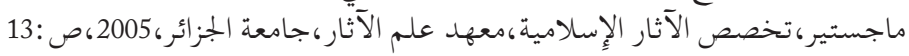


مكنَّها من أن تكون همزة وصل بينهما في الميدان التجاري منذ القدم، تحدها شمالاً

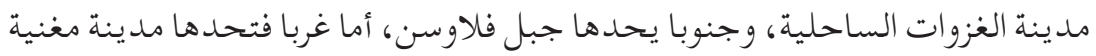

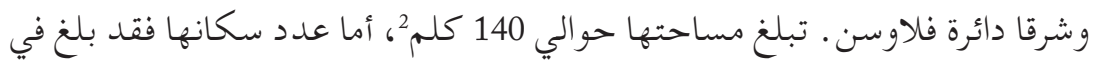

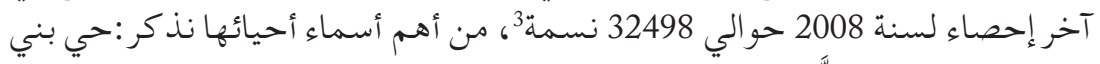

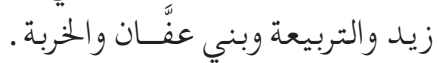

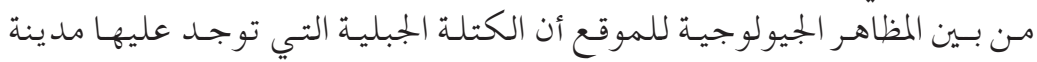

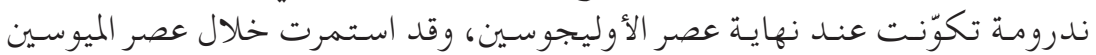

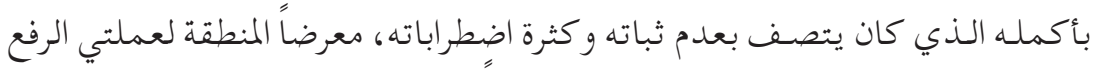

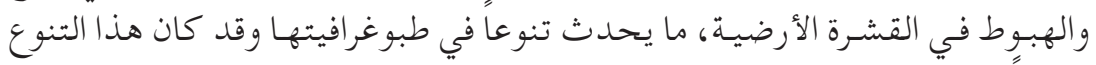

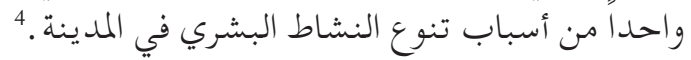

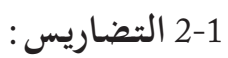
تقع ملدينة ندرومة في قلب سلسلة جبال ترارة، تتميز بـجيوب زبلـ زراعية على هيئة

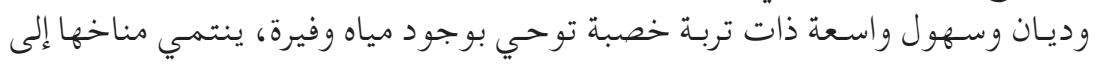

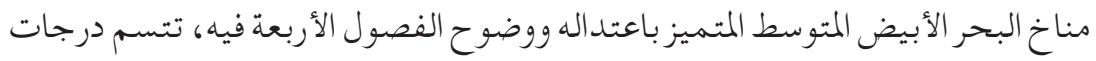

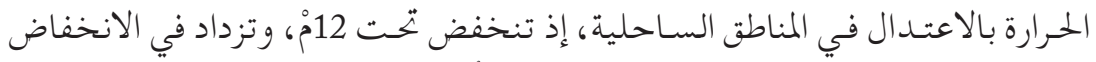

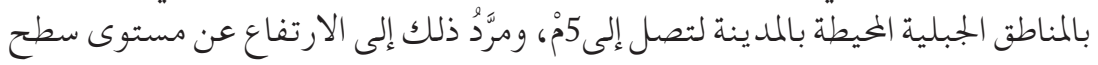

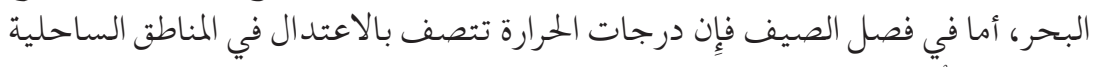

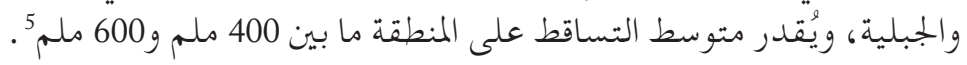

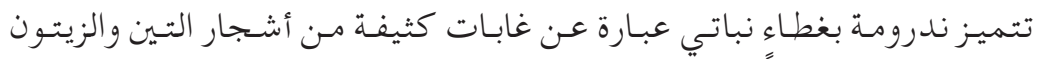

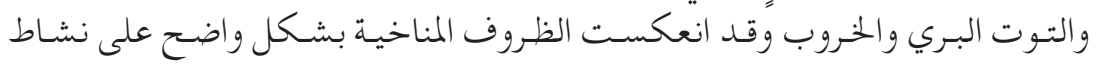

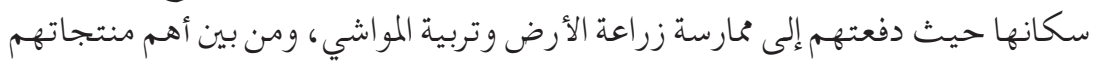

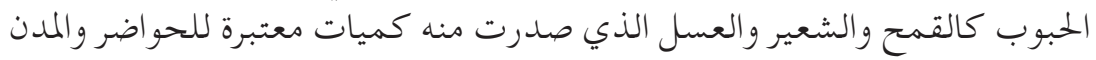

$$
3 \text { نقلاً عن بلدية ندرومة ، إحصاء } 2008
$$

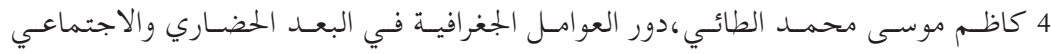

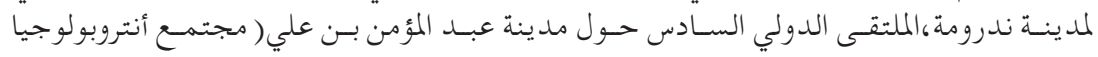

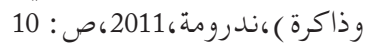

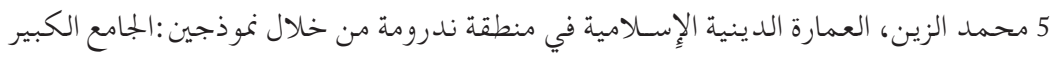

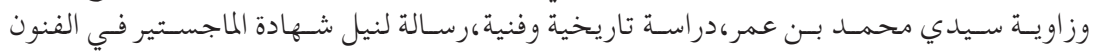

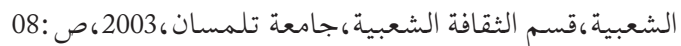




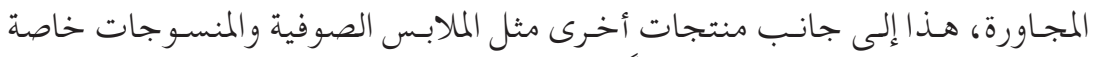

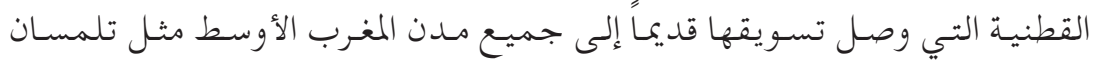

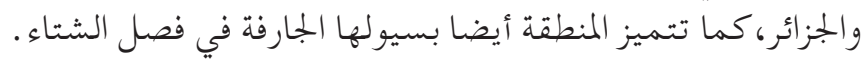

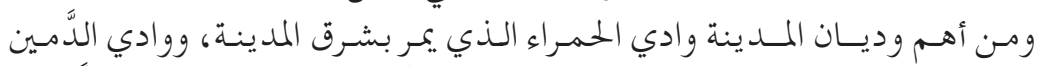

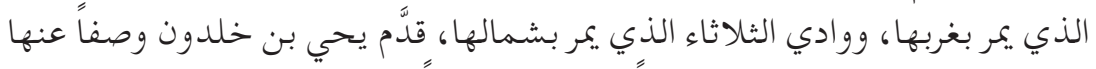

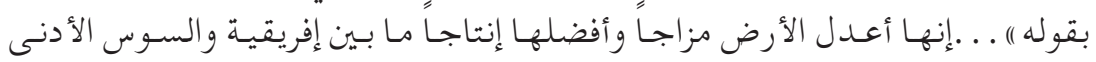

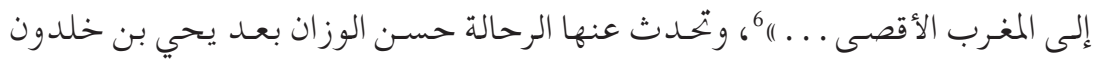

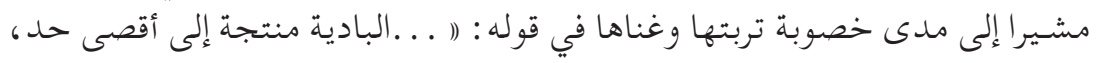

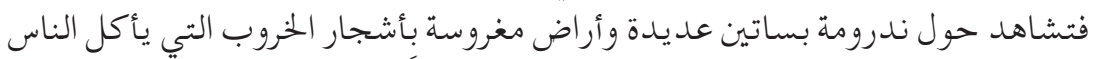

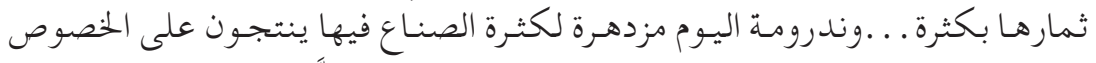

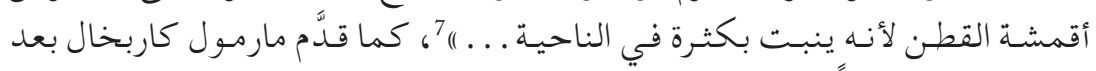

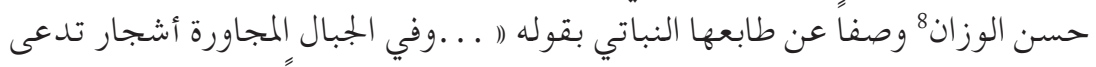

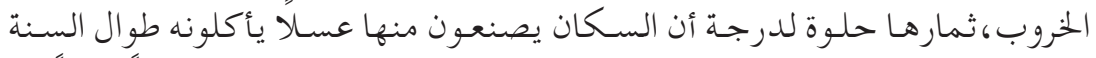

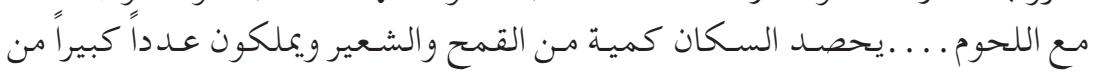

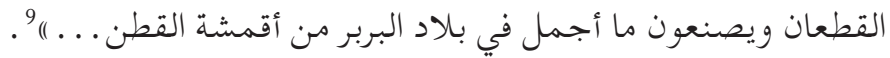

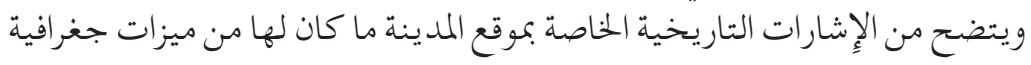

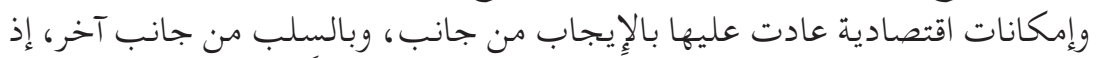

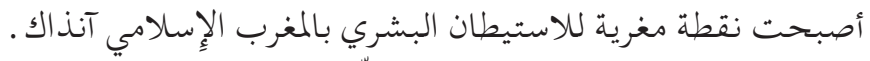

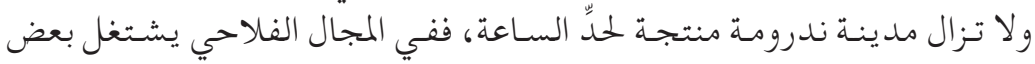

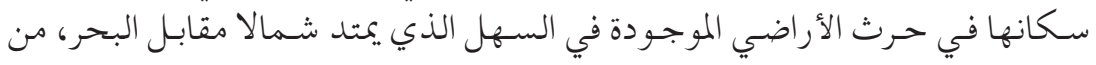

$$
6 \text { يتحي بن خلدون، مصددرسابق،ص: } 84
$$

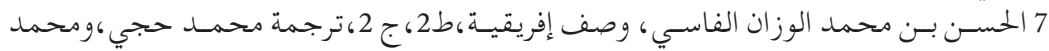

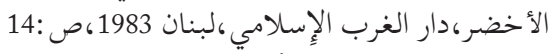

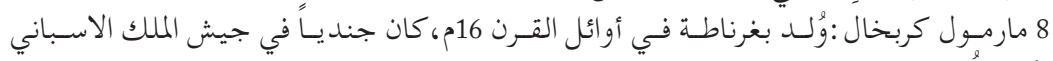

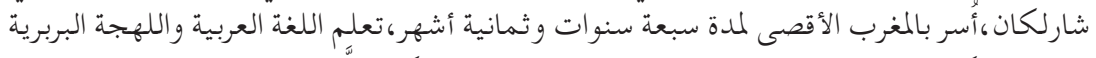

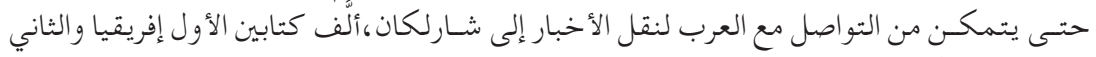

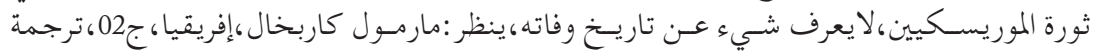

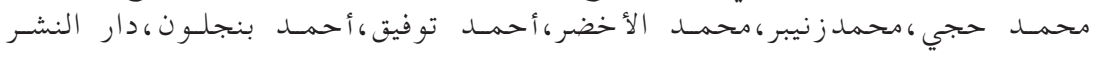

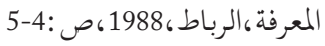
9 مارمول كربخال، ،المصدر نفسه، :5 : 295 
جملة منتوجاتهم القمح والشعير والطماطم، أضف إلى ذلك اهتمامهم بغرس أشجار

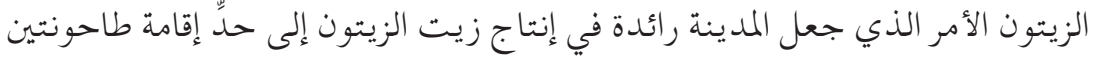

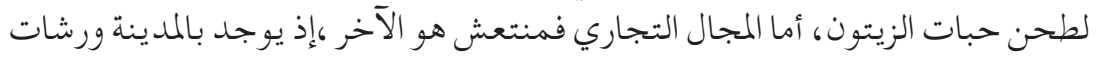

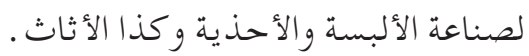

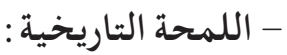

تعتبر مدينة ندرومة واحدة من الحو اضر الإِسلامية الزاخرة بإِرث معسماري وعمراني

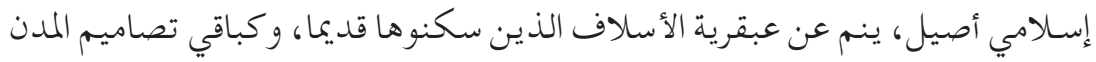

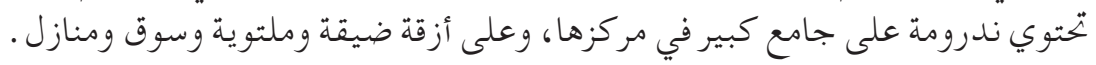

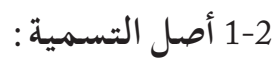

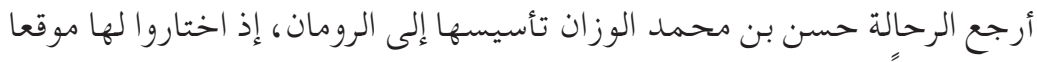

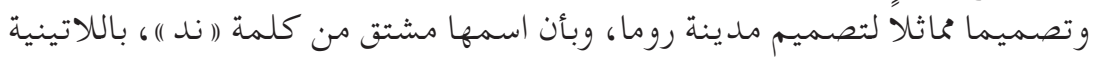
بsimilis»

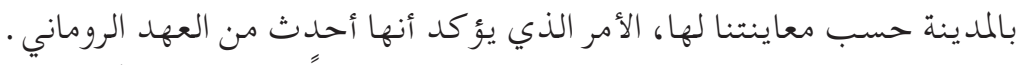

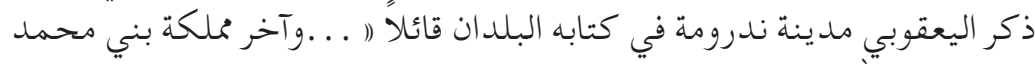

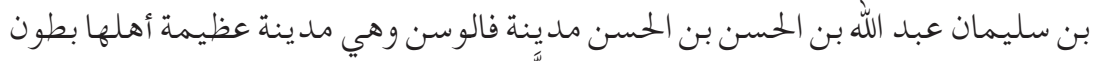

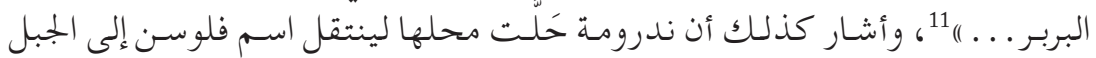

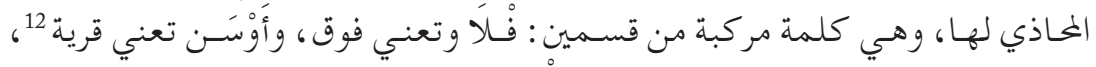

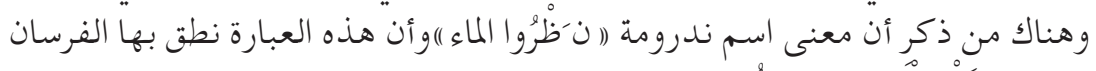

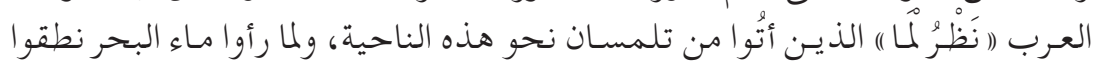

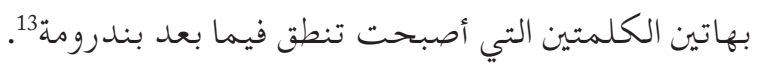

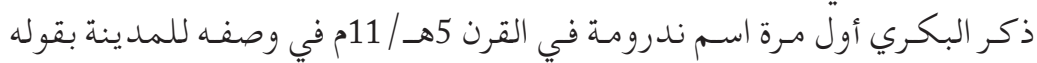

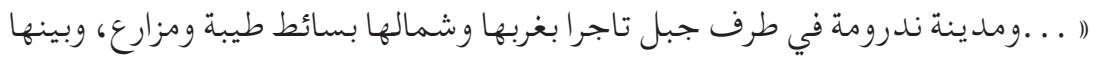

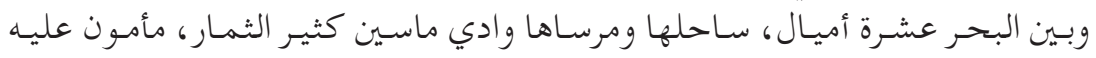

$$
10
$$

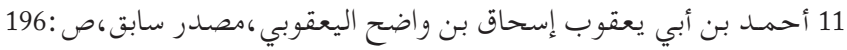

12 René Basset, Nedromah et Les Traras, París, Ernest Leroux Editeur, 1901, pág. 5-7.

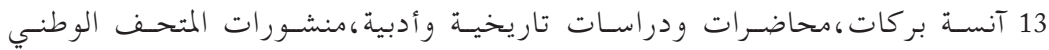

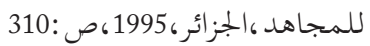




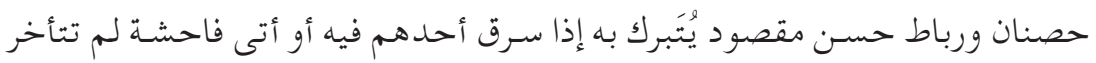

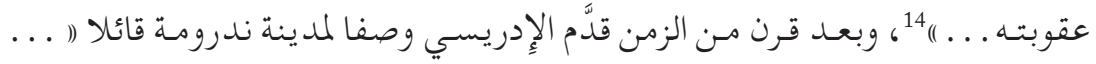

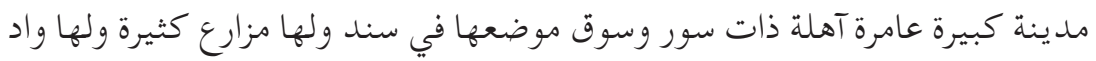

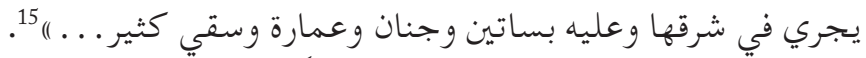

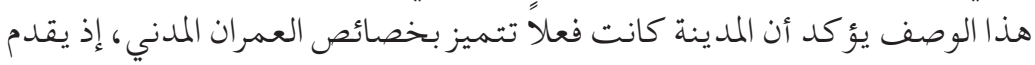

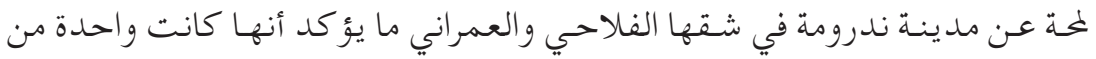

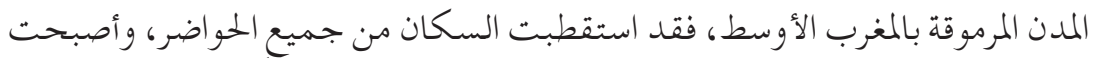

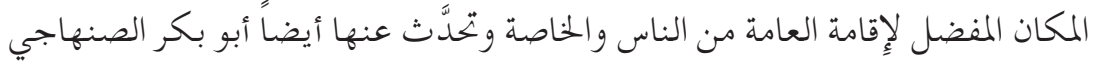

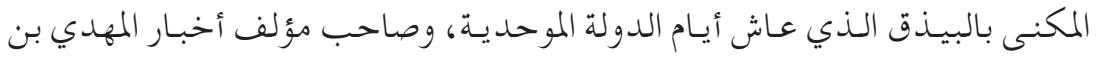

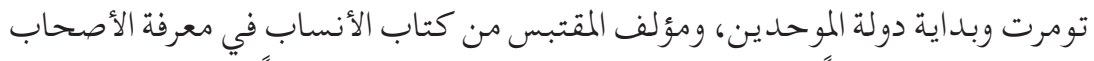

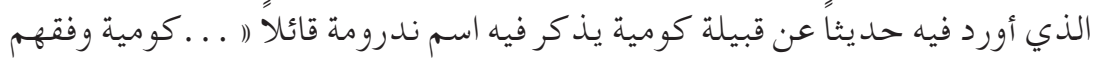

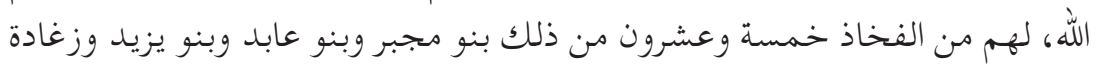

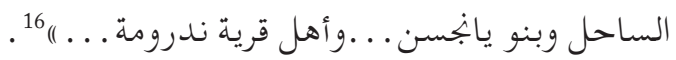

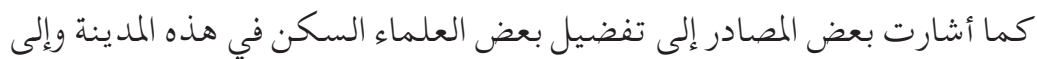

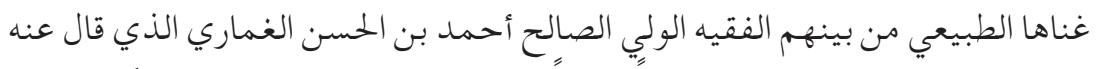

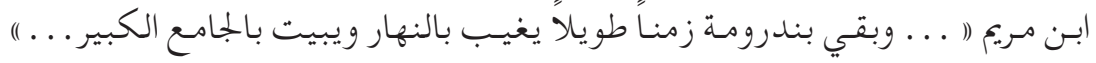

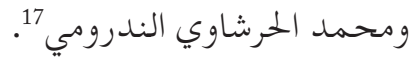

\section{2-2 أهم الفترات التاريخية التي مرت بها مدينة ندرومة العتيقة :}

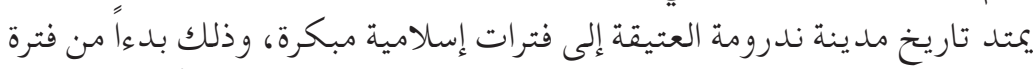

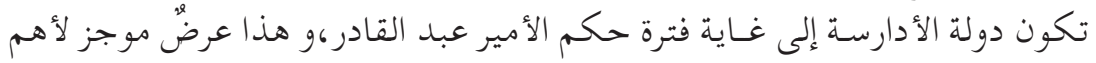

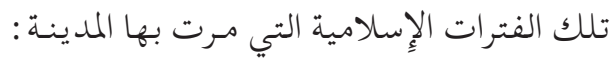

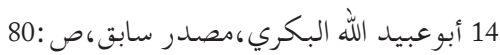

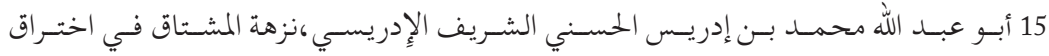

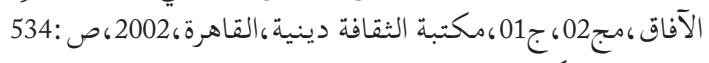

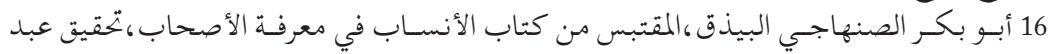

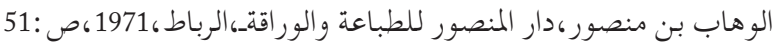

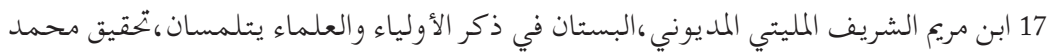

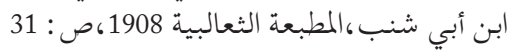




\section{ندرومة في فترة الأدارسة :}

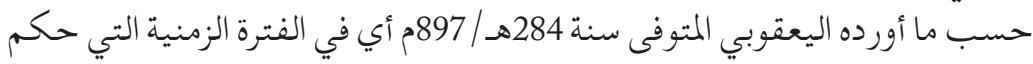

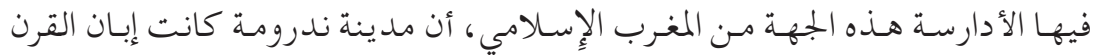

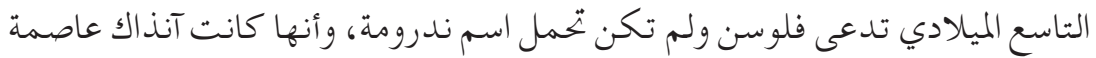

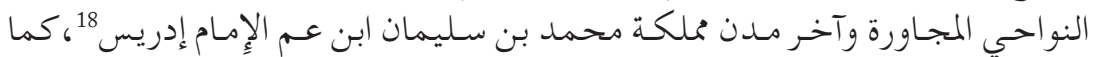

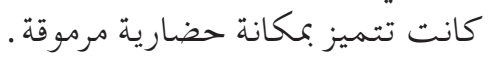

\section{ندرو مة في فترة الفاطميين :}

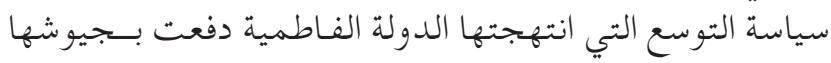

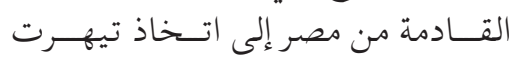

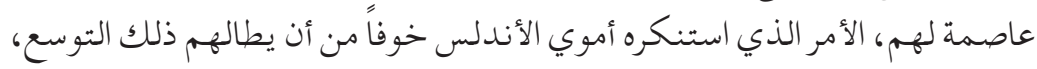

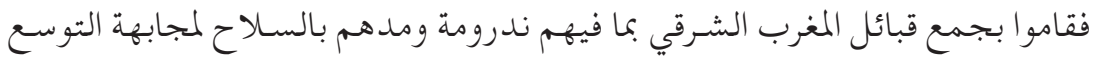

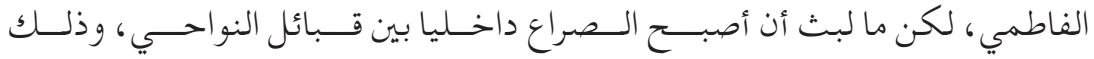

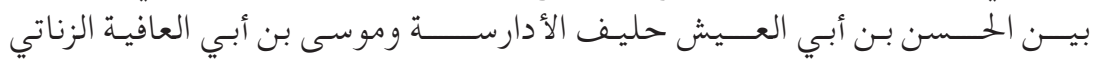

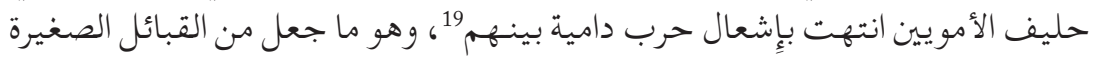

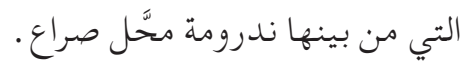

ندرومة في فترة الحماديين :

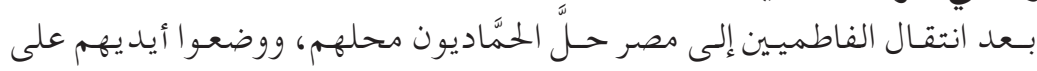

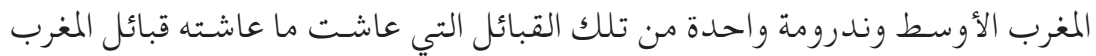

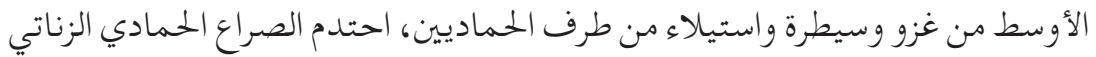

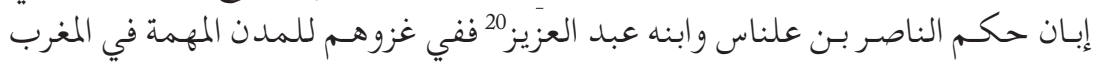

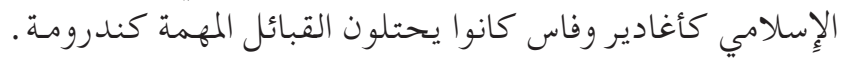

$$
\text { ندرومة في فترة المر ابطين : }
$$

يقول صاحب الاستقصاء أنه لما دخلت سـنة 454هـ / 1061م استفحل أمر يوسف

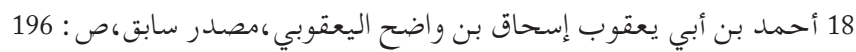

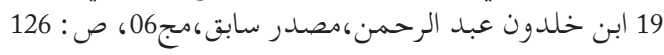

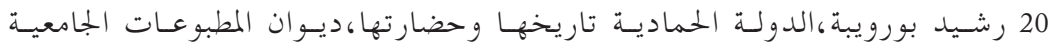

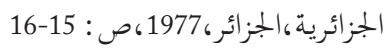




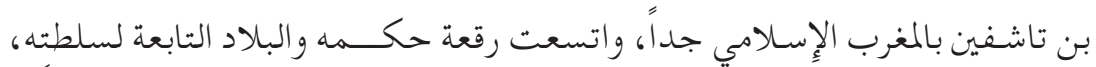

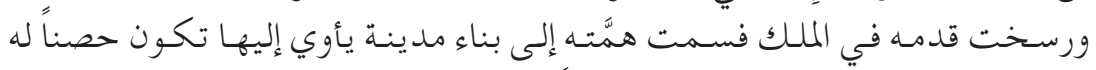

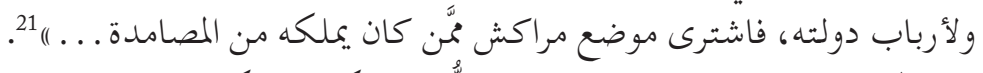

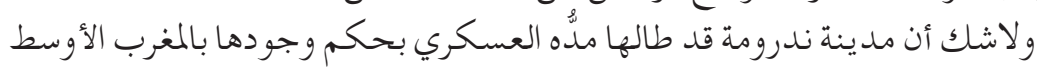

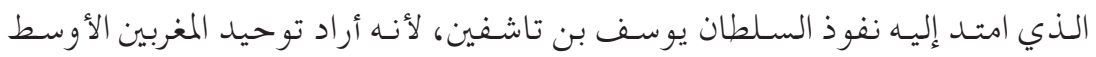

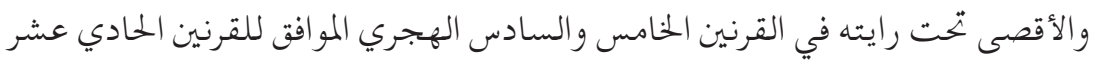

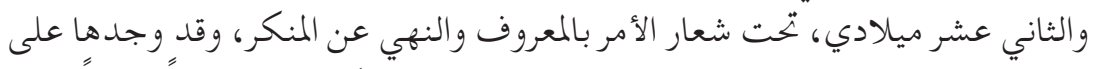

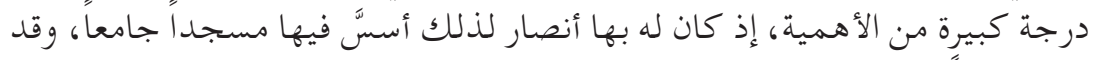

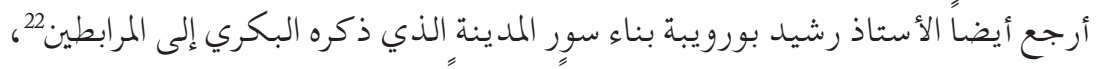

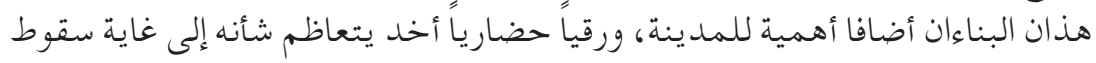

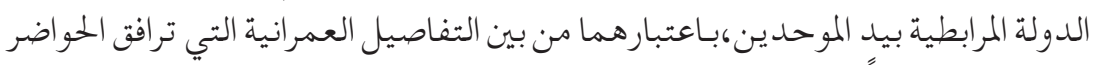
المرموقة اجتـماعياً.

\section{ندرومة في فترة الموحدين : ملدئ}

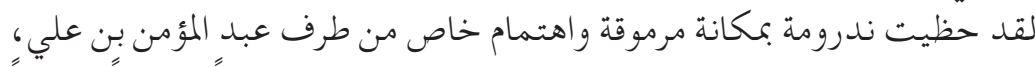

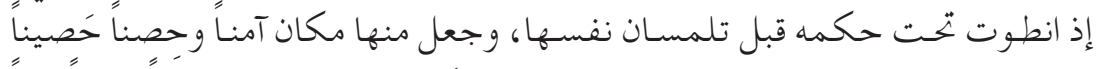

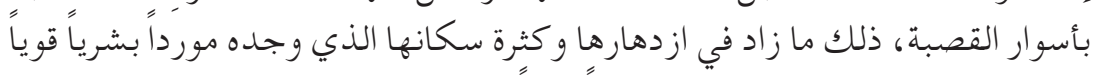

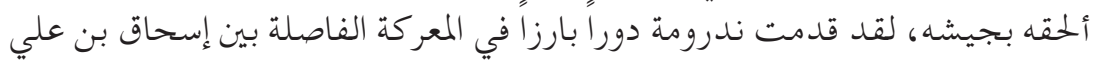

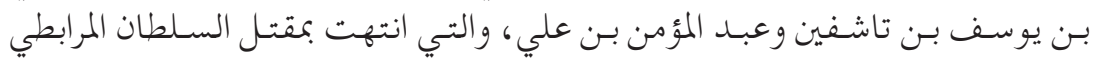

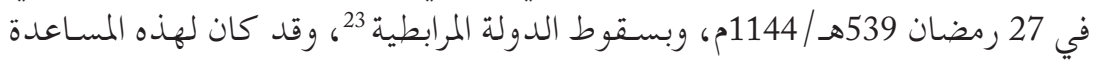

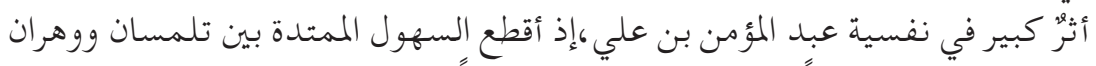

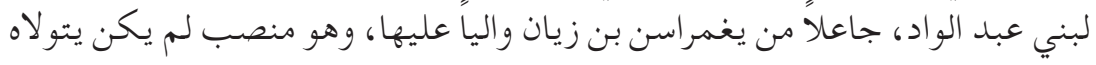

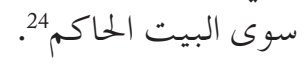

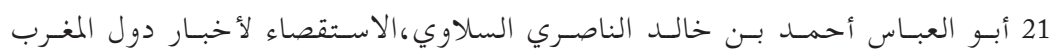

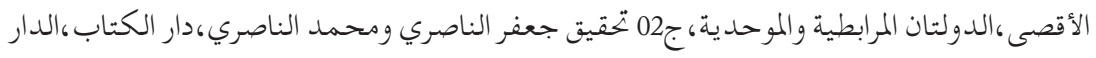

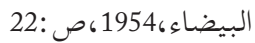

22 Rachid Bourouiba, L'architecture Militaire de L'Algérie Médiévale, Argel, OPU, 1983, p. 93.

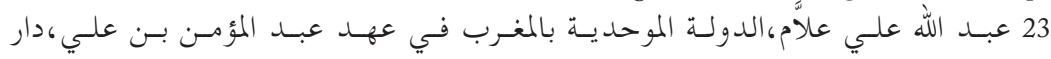

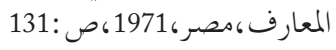
24 شـارل أندري جوليان، تاريخ إفريقيا الشمالية، العصر الإِسلامي، ترجمة محمد مزالي، البشير 


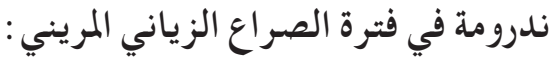

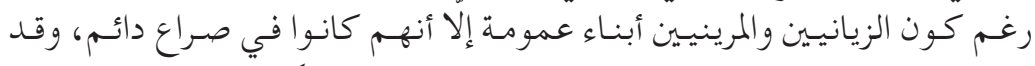

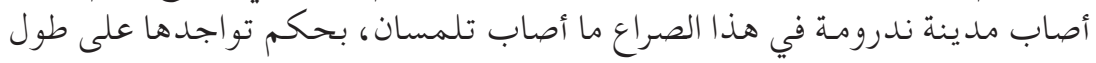

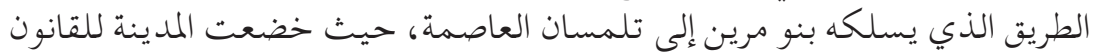

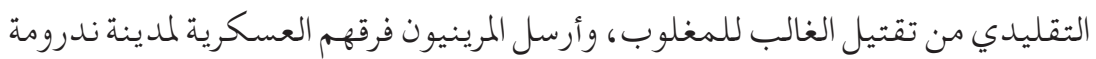

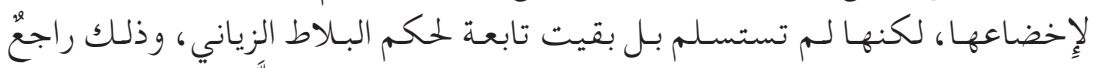

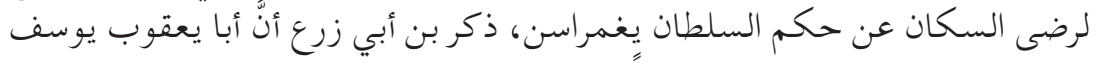

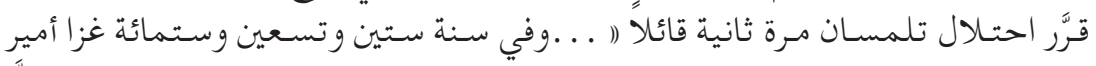

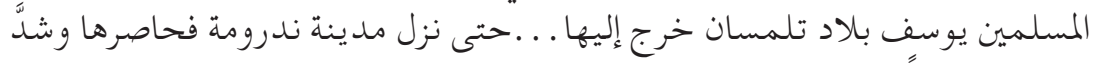
في قتالها أياماً ثم ارتحل عنها . . .).

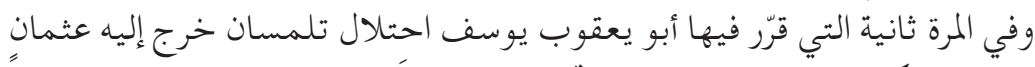

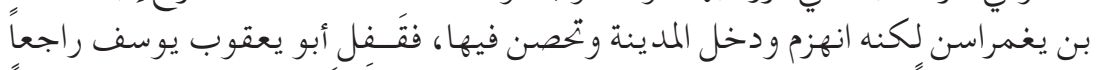

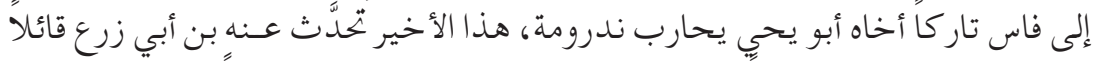

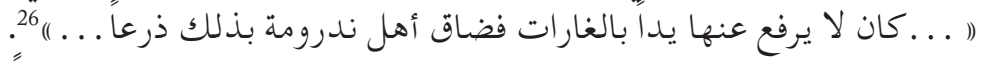

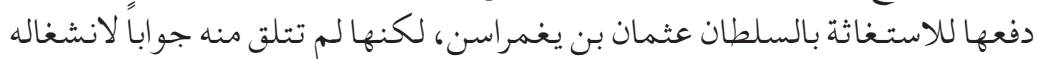

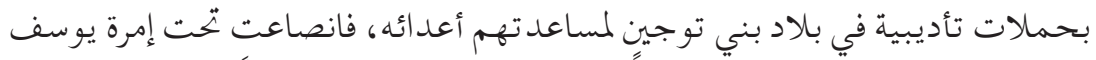

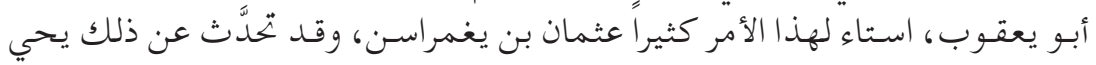

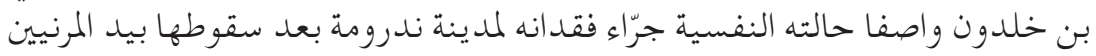

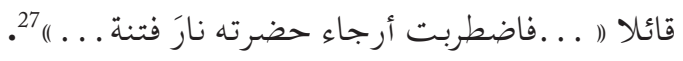

\section{ندرومة في فترة الأتراك : بك اك}

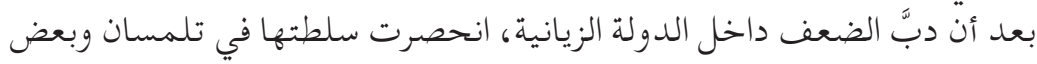

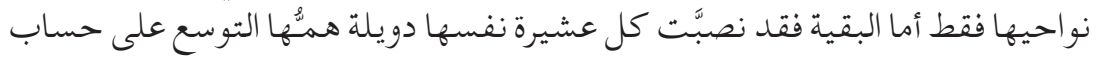

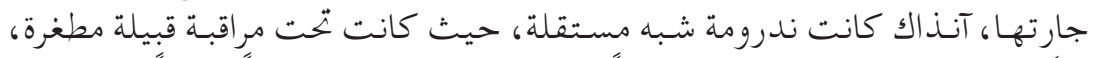

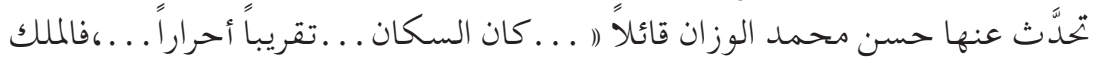

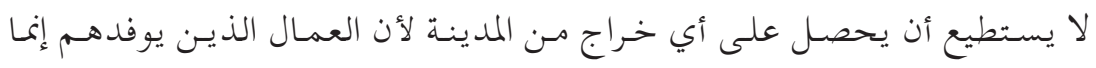

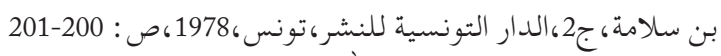

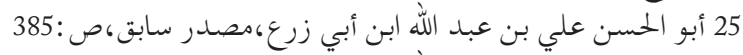

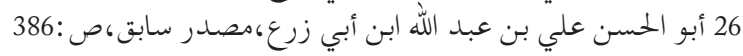

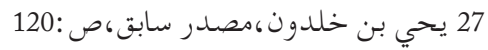




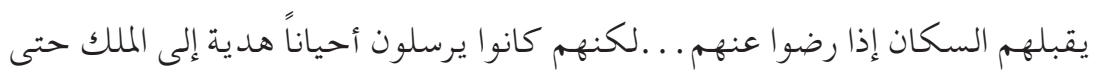

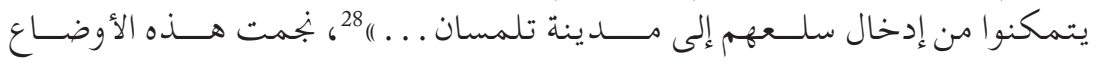

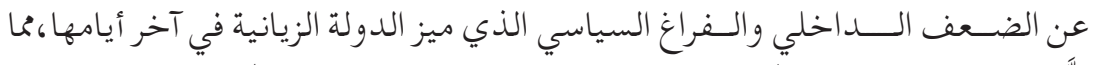

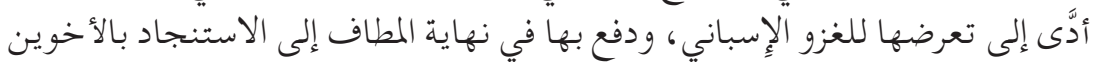

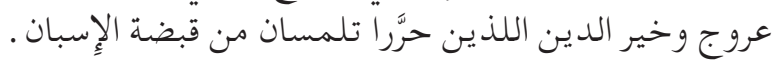

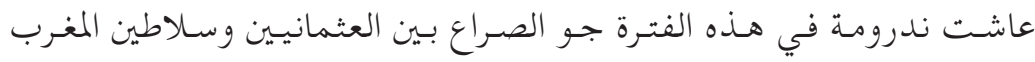

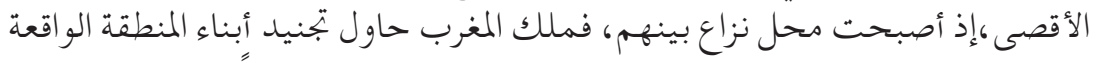

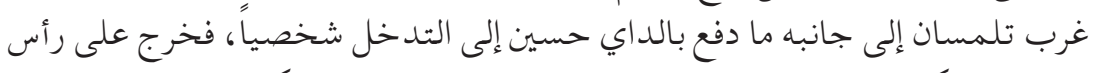

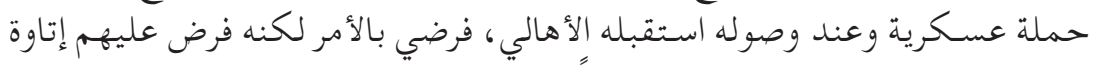

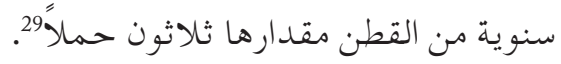

\section{ندرومة في فترة الأمير عبد القادر:}

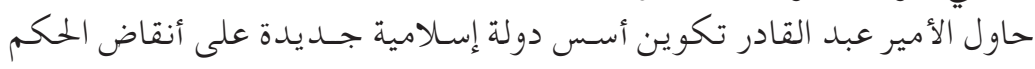

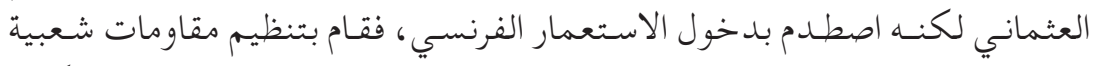

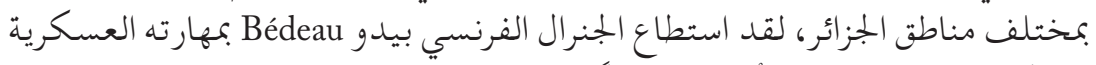

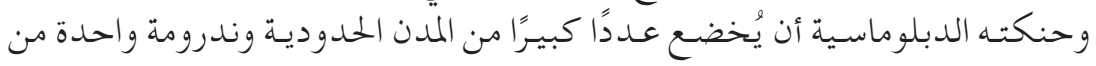

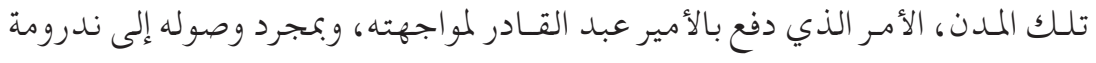

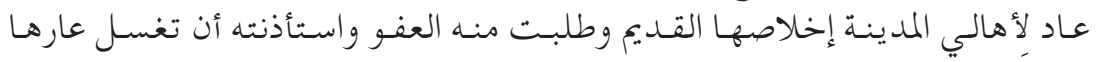

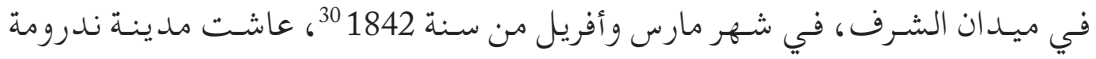

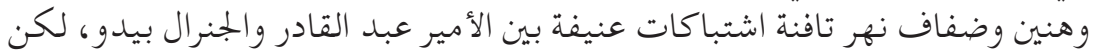

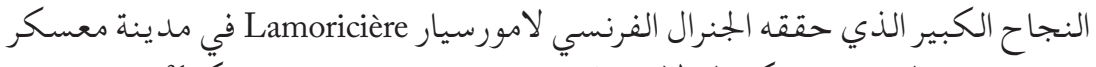

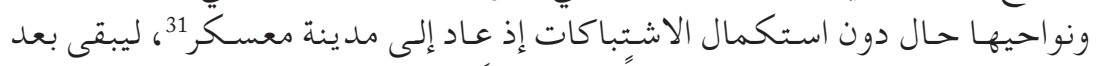

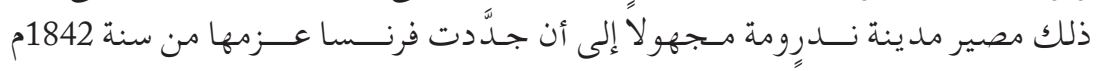
وقامت باحتلالها نهائيا.

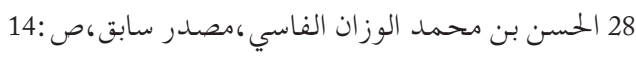

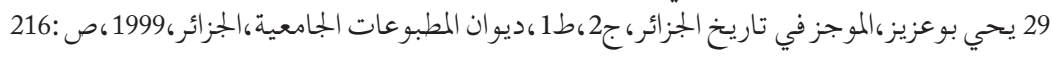

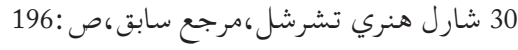

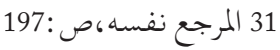



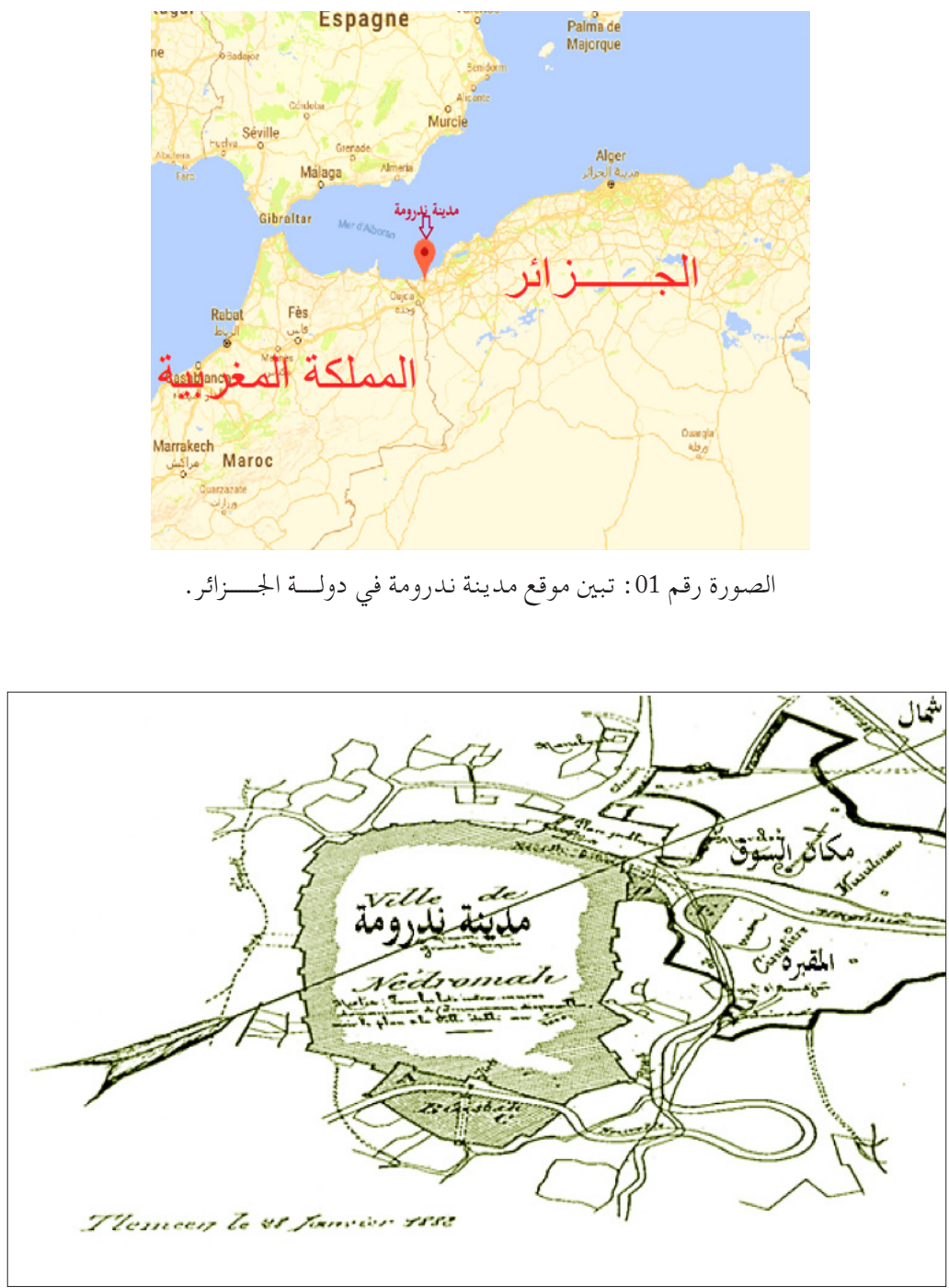

المخطط رقم 01 :يبين حدود التصميم العمراني لمدينة ندرومة سنة 1882،عن

Abderrahmane Khelifa,Honaïne Ancien..., Op.Cit, p. 180 


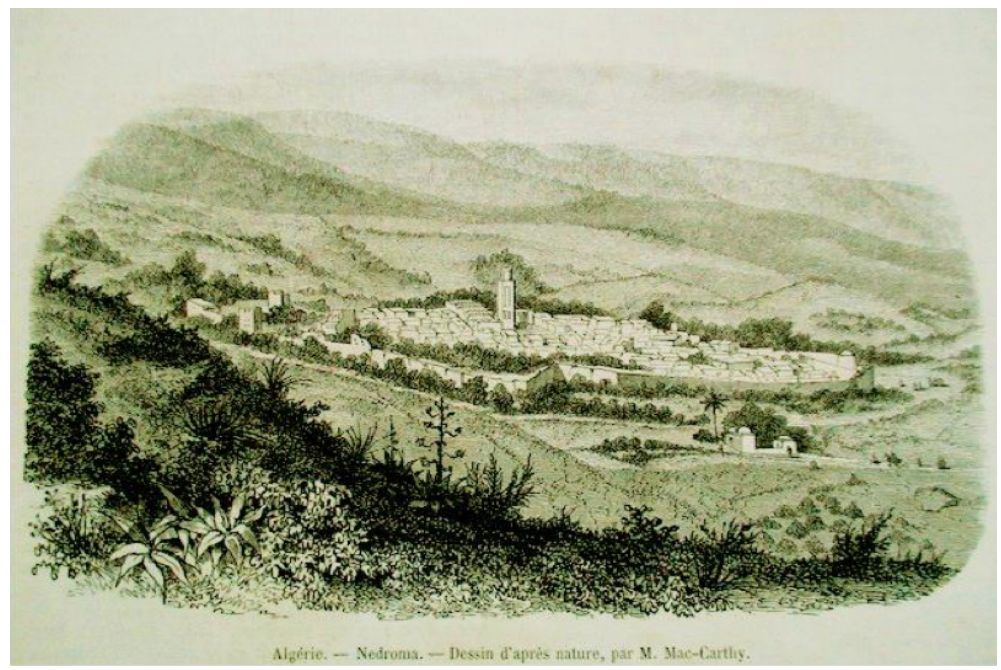

$$
\begin{aligned}
& \text { الصورة رقم 02: تبين رسم لمنظر عام لمدينة ندرومة في القرن 19م، من طرف ماك كارتي }
\end{aligned}
$$

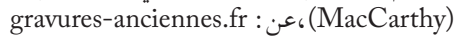

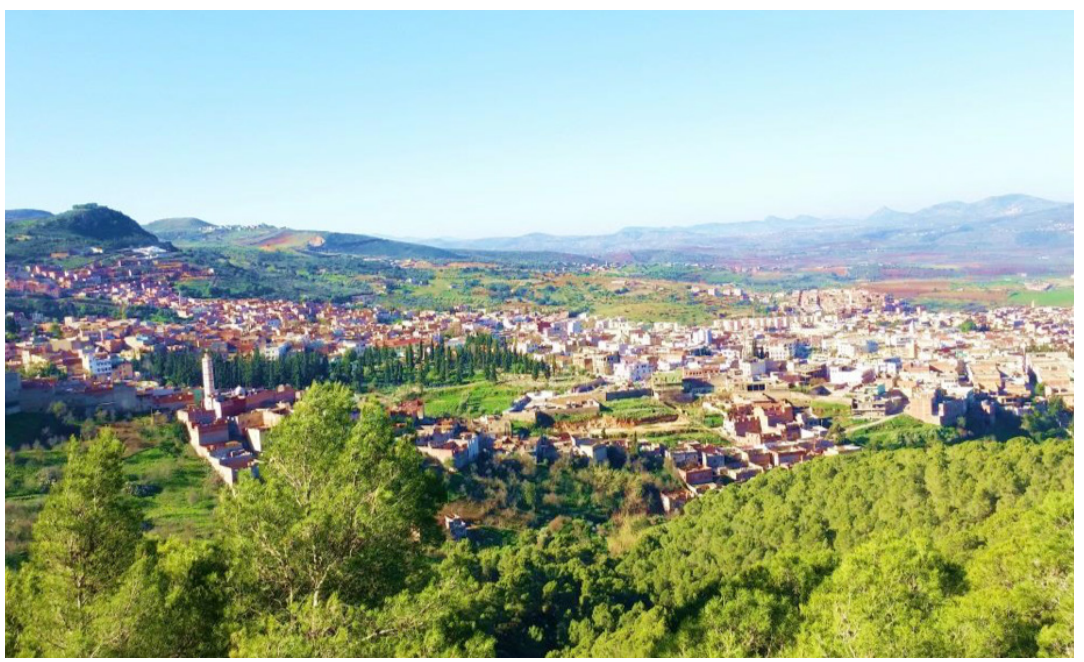

$$
\text { الصورة رقم } 03 \text { : تبين المنظر الحالي لجزء من مدينة ندرومة الممتد فوق سفح }
$$


153 Aproximación geográfica e bistórica a la ciudad de Nedroma

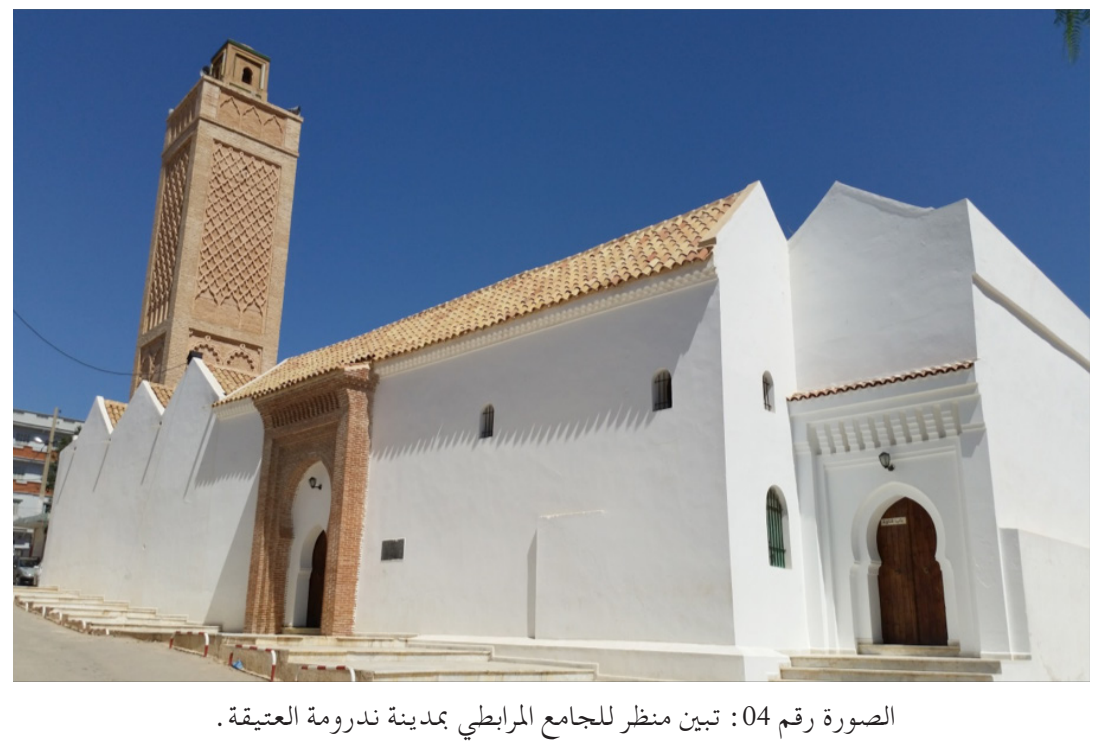





\title{
مساهمة التحكيم التجاري الدولي في تفعيل الأمن القانوني للاستثمار الجزائري بالحارج LA CONTRIBUCION DEL ARBITRAJE COMERCIAL INTERNACIONAL PARA ACTIVAR LA SEGURIDAD JURIDICA DE LAS INVERSIONES ARGELINAS EN EL EXTRANJERO
}

\author{
عباسـة طاهر \\ جامعة عبد الحميد بن باديس - مستغانم

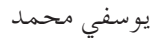 \\ جامعة عبد الحميد بن باديس - مستغانم

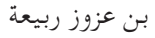 \\ جامعة تلمسان \\ Taher AbBassa \\ Universidad Abdel Hamid Ben Badis - Mostaganem \\ Mohammed Yousfi \\ Universidad Abdel Hamid Ben Badis - Mostaganem \\ Rabia Ben Azzouz \\ Universidad de Tremecén
}

\section{Resumen}

Si bien muchos países aplican privilegios legales para atraer inversiones extranjeras y capital internacional, todavía existe la necesidad de forzar a los inversionistas extranjeros a buscar una solución dentro del régimen jurídico nacional a las controversias de un litigio local, que se considera de protección legal limitada para el inversionista extranjero en general y para el inversionista argelino en particular dentro del país anfitrión. Todo lo cual desalienta al inversionista y reduce su confianza en el clima de inversión. En este marco, el Estado argelino ha tratado de concluir varios acuerdos bilaterales para alentar y proteger las inversiones extranjeras a través del arbitraje comercial internacional, ya que la convención se considera vinculante y no se puede revertir. En el presente trabajo se estudian las ventajas legales del arbitraje internacional en la resolución de conflictos, y su aplicación en el ámbito argelino.

Palabras clave: Inversión extranjera, arbitraje de comerciantes internacionales, protección legal, país anfitrión, resolución de conflictos. 


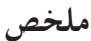

على الرغم من قيام العديد من البلدان بإصلاحات قانونية لجذاتب المستثمرين إلا أنها ما زالت الت تعاني

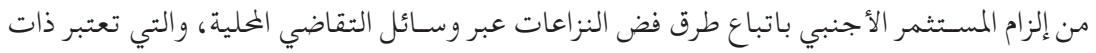

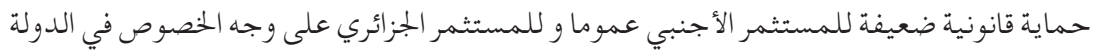

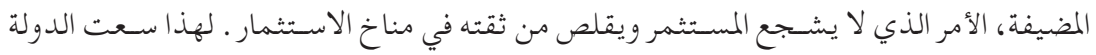

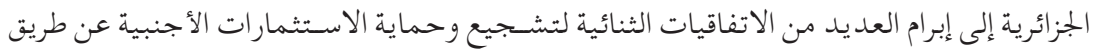

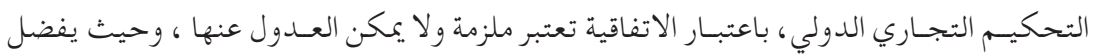

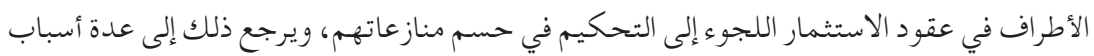

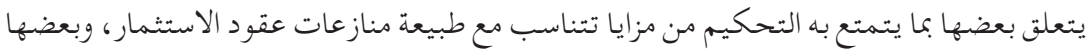

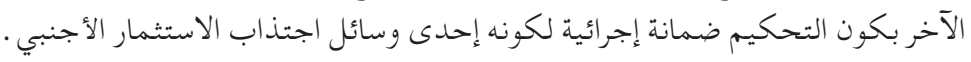
الكلمات المفتاحية : الاستثمار الأجنبي ـ التحكيم التجار الدولي ـ الحماية قانونية ـ الدولة المضيفة لاستثمار ـ فض النزاعات

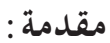

مـا من شـك أن رؤوس الأموال واحتياطي الدولـة مـن العملة الصعبة تلعـب دورا هاما

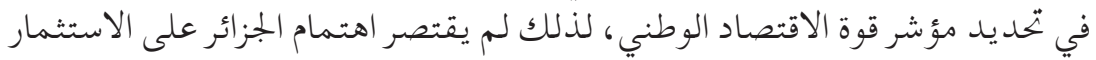

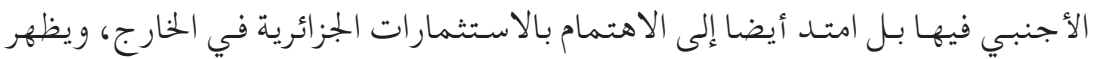

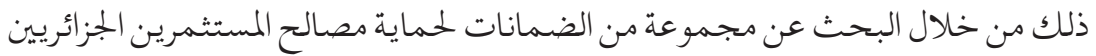

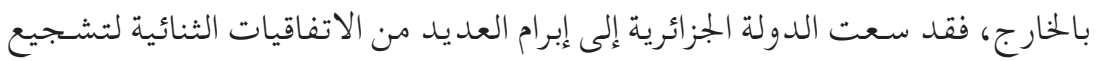

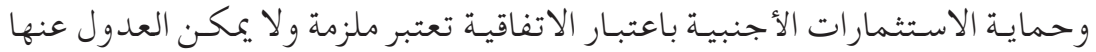

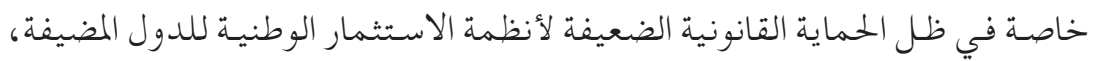

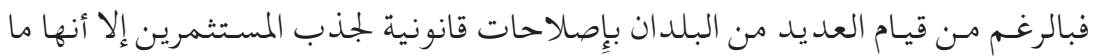

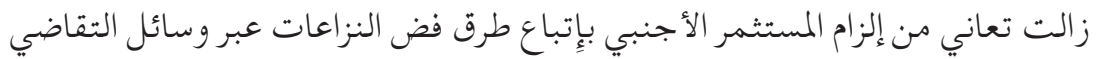

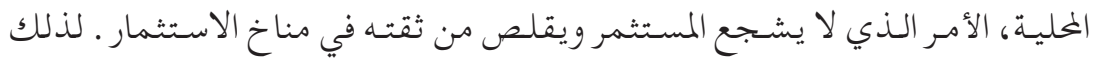

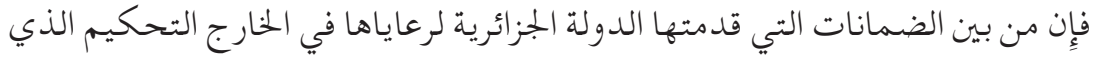

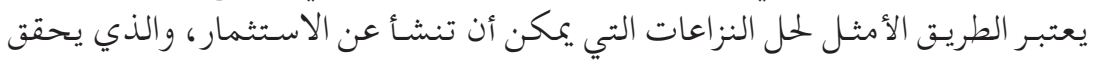


الطمأنينـة للمستشتمر الجزائري في حالة اصطلـام حقوقهه مـع حقوق ومصالح الدولة المضيفة، خاصة في ظل عدم توصل المجتمع الدولي إلى إنشاء آليات لهيئة التحكيم العالمية تتولى توحيد الحلول القانونية بشأن منازعات الاستثمار .

فِإِلى أي ملدى يمكن اعتبار التحكيم التجاري الدولي آلية لضمان الأمن القانوني

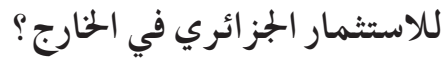

\section{المبحث الأول : مجال الاستثمار الجزز ائري في الحنارج}

حاول المشـرع الجزائري والبنك المركزي ضبط وتنظيم الاستثمارات الأجنبية في

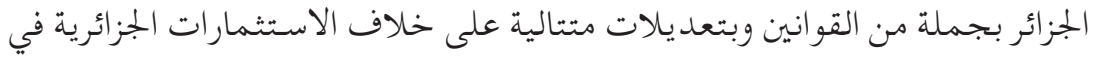

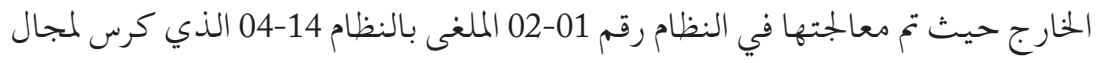

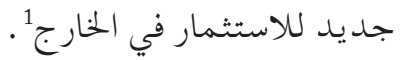

المطلب الأول : تحديد مجال الاستثمار بالحنارج

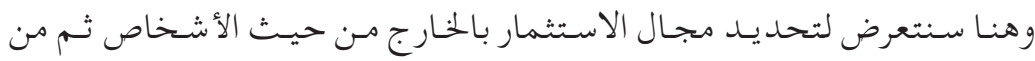
حيث النشاط . (مئاس.

أولا : من حيث الأشخاص :

تم تحد يد هذا المجال في المادة الأولى من نظام 14-04 السابق ذكره، حيث بينت هذه المادة الأشخاص المسـموح لهم بالاستثمار بالخارج، وحدد وهم بالمتعاملين الاقتصاديين

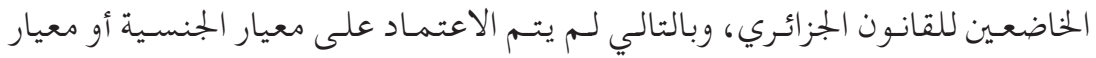

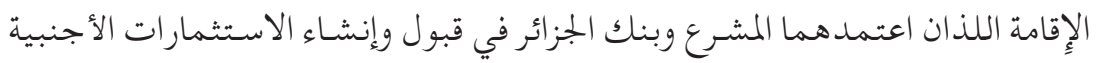
في الجزائر وفي تحويل وإعادة التحويل إلى الخارج².

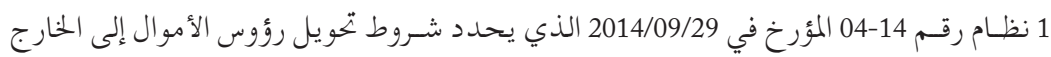

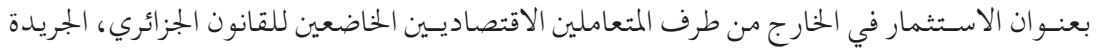

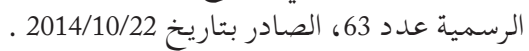

2 Rachid Zouaimia, "Réflexions sur la sécurité juridique de l'investissement étranger en Algérie", R.A.R.J., Faculté de droit, Université Abderrahmane MIRA, Bejaia, 2010, núm. 1. 


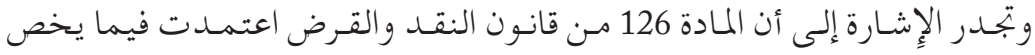

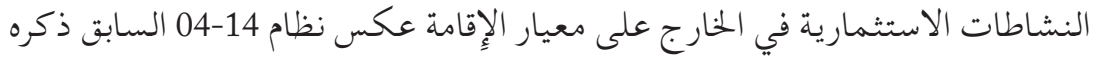

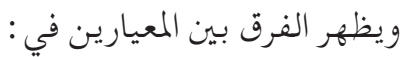

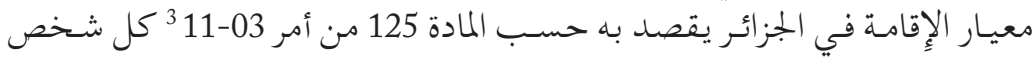

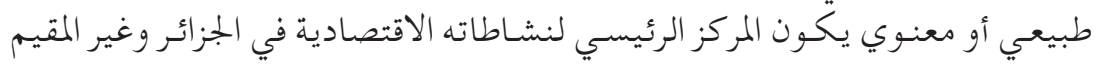

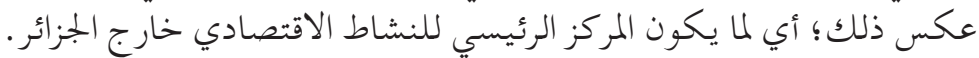

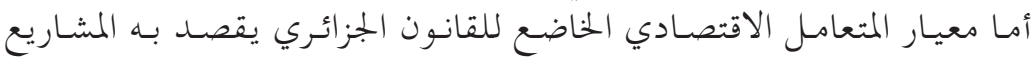

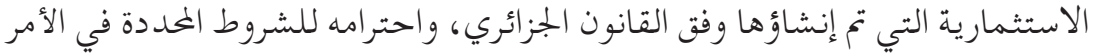

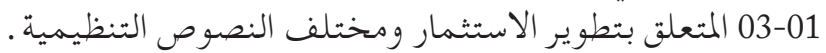

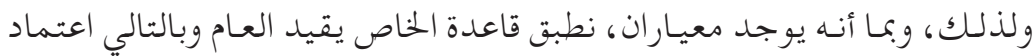

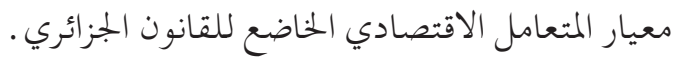
ويترتب عن ذلك النتائج التالية:

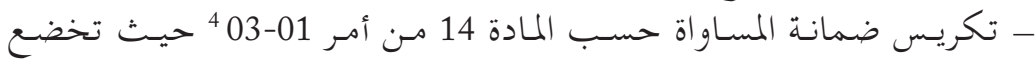

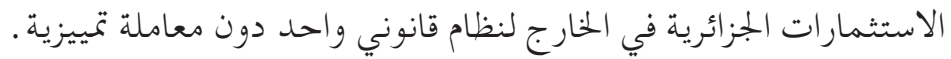

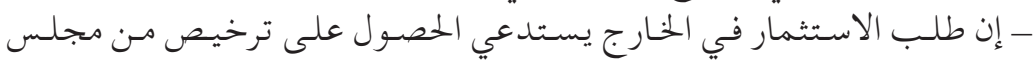

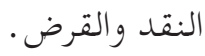

\section{ثانياً : تحديد مجال الاستثمار بالخارج من حيث النشاط :}

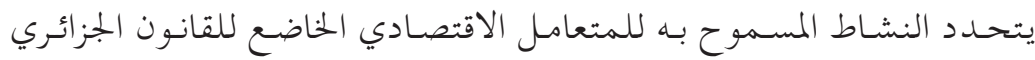

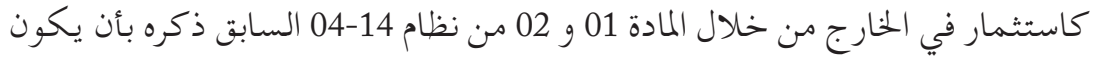

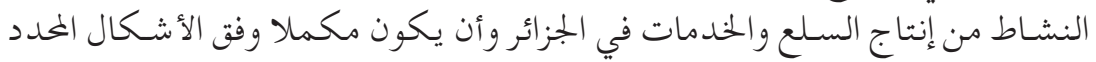
في المادة 02 من نفس النظاج النطام .

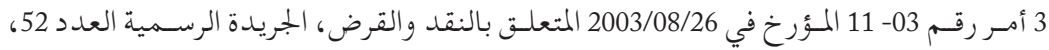

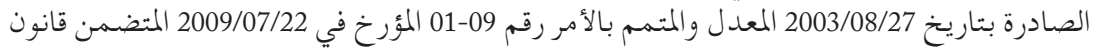

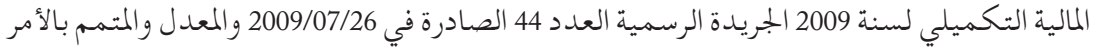

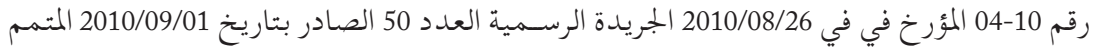

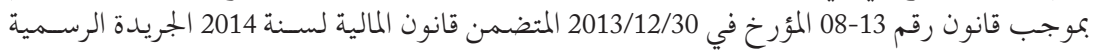
عدد 68 الصادرة بتاريخ 2013/12/31 .

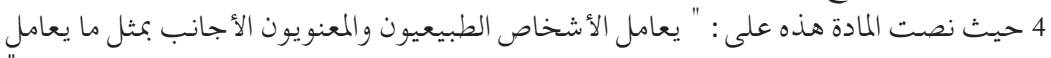

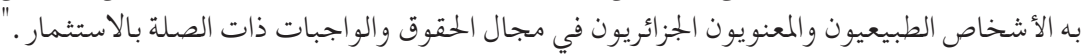




\section{فبالنسبة للشرط الأول :}

يعني أن تكون النشـاطات المنتجة للسـلع هي تلك المتعلقة بتحويل المواد الأولية

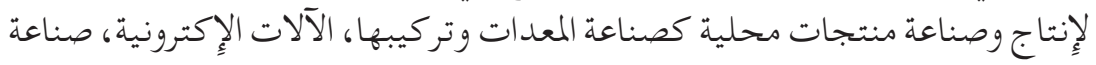

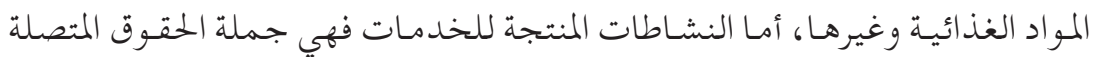

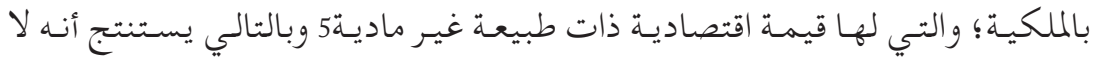

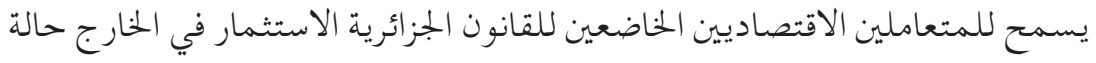

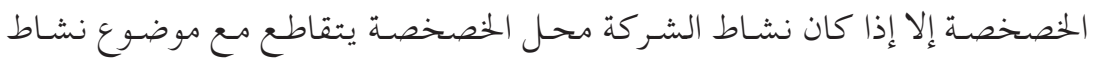

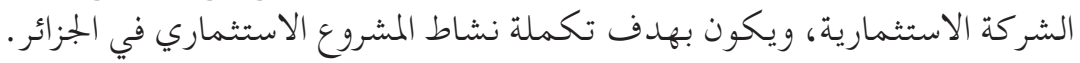

أما بالنسبة للشرط الثناني :

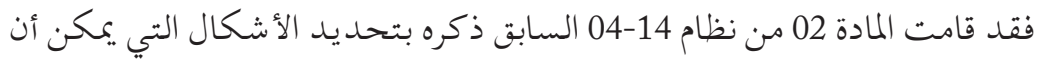

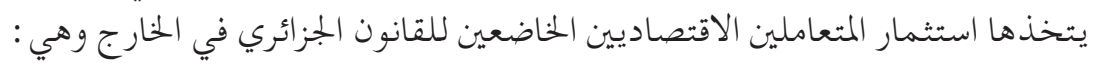

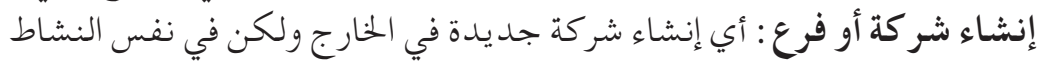

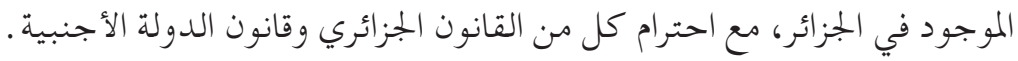

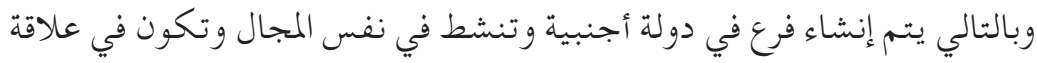
مباشرة بالشركة الأم الجزائرية .

\section{أخذ مشاركات في شركات موجودة في شكل مساهمات نقدية أو عينية}

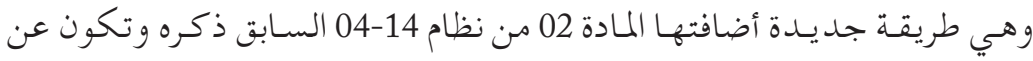

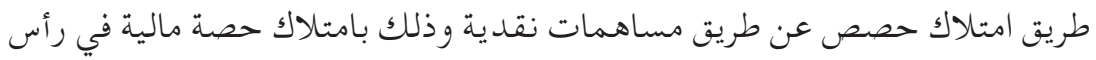

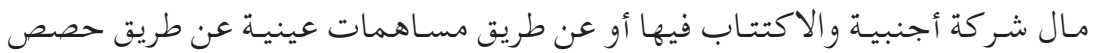

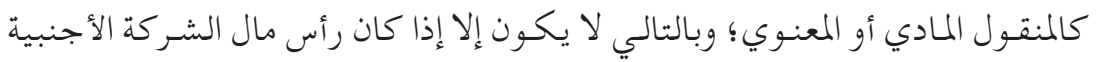
عبارة عن أسهم .

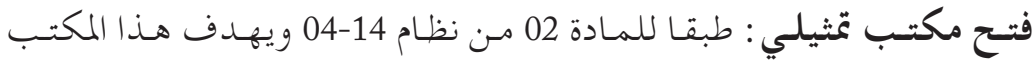

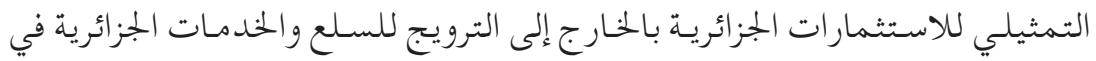

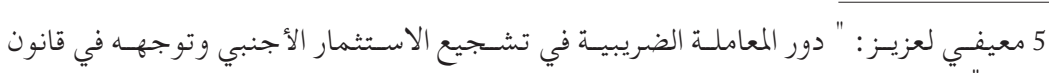

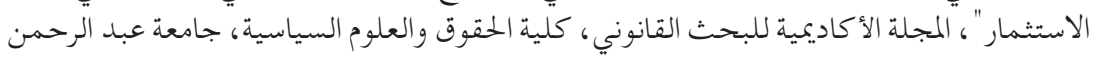
ميرة، بجاية، العدد 2011/02، ص المجلة 59. 


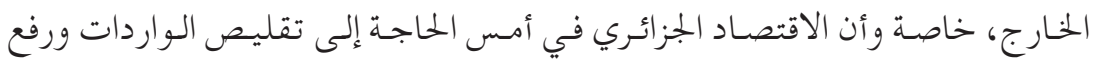

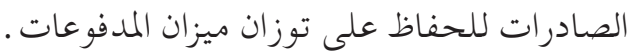

\section{المطلب الثاني: شروط قبول الاستثمار خارج المجزائر}

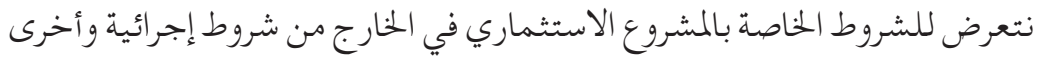

موضوعية، ثم إلى الشروط الخاصة بالدولة المستضيفة للاستثمار بالخارج.

\section{أولاً: الشروط الخاصة بالمشروع الاستثماري في الخارج}

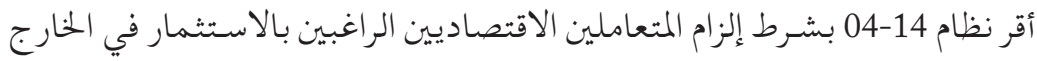

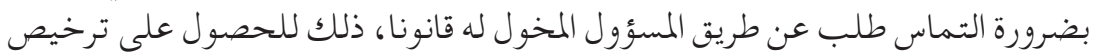
من طرف مجلس النقد والقرض كرقابة إجرائية، بالإضافة إلى شروط لمرنال موضوعية :

\section{1- إلز امية الحصول على الترخيص :}

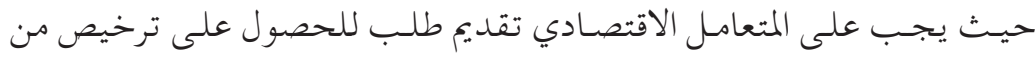
مجلس النقد والقرض مرفقا بالو ثائق الداخلية :

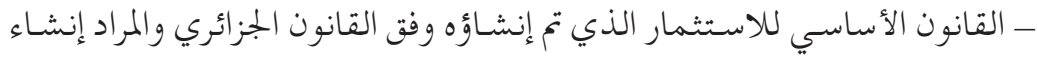

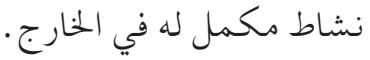

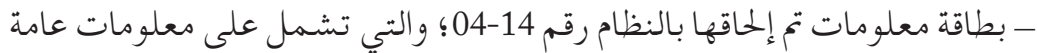

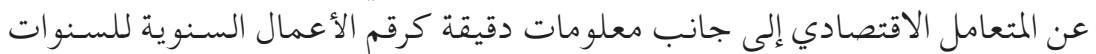

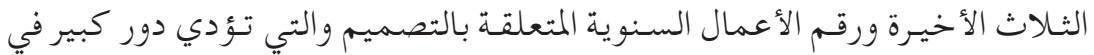

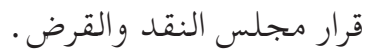

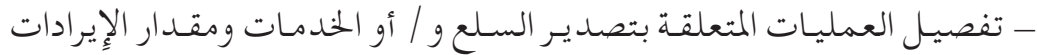

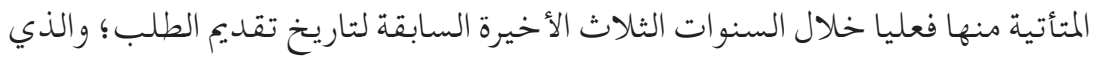

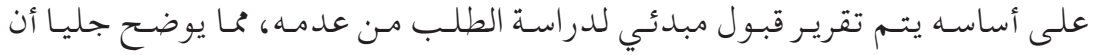

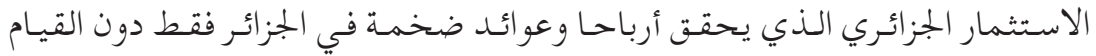

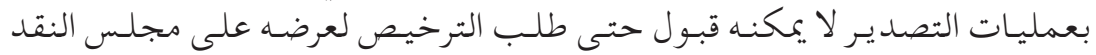

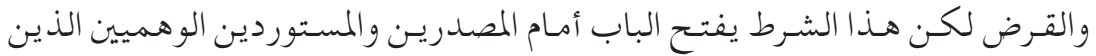

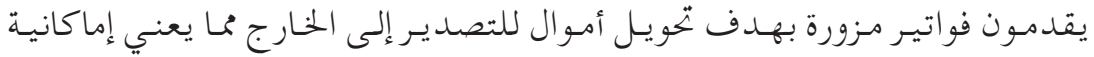
تقديمهم طلب للاستثمار في الخارج. 


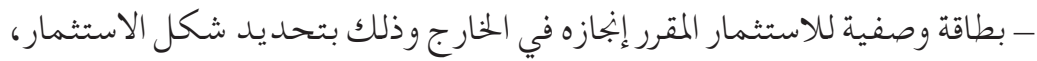

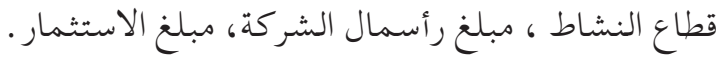

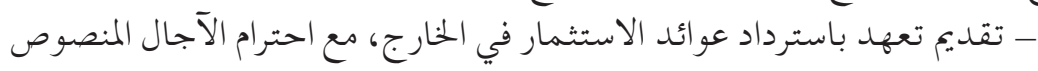

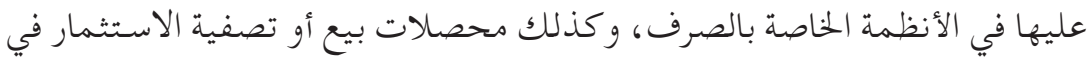

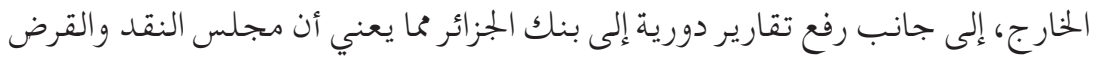

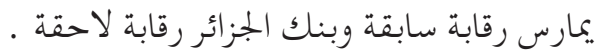

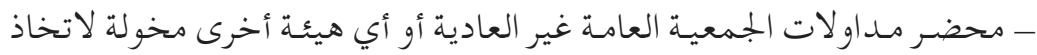

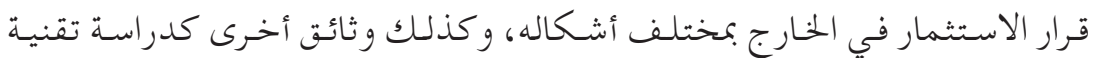

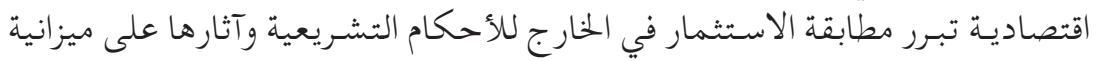
العملة الصعبة .

- شهادة من المصالح الجبائية تبرر وضعية المتعامل الاقتصادي تجاه الإِدارة الجبائية،

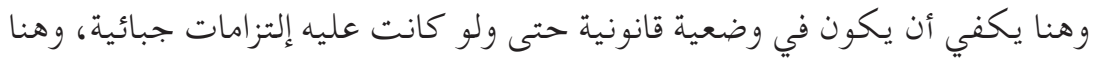

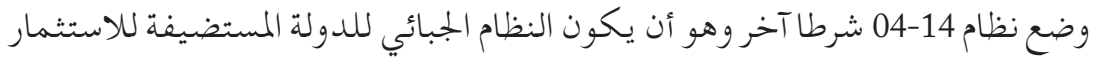
شفافا ولا يمنع تشريعه تبادل المعلومات في المجالين القضائي والجبائي .

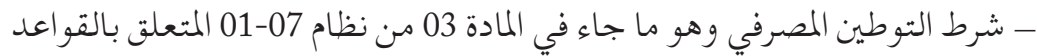

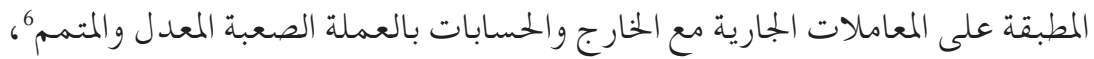

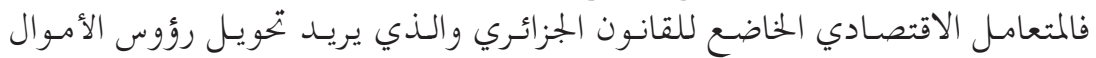

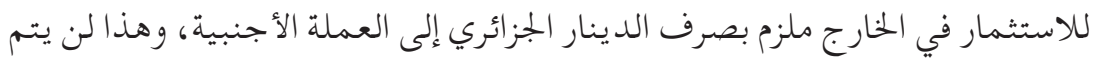

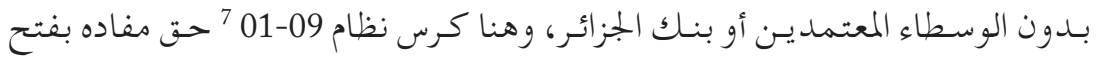

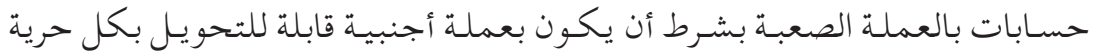
لدى بنك أو وسيط معتمد . 2- شرط النشاط التكاملي : أي يجـب أن يكـون النشـاط المراد إنشـاؤه في الخارج مكملا للنشـاط الموجود في

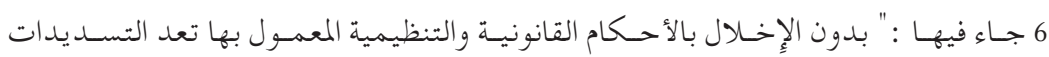

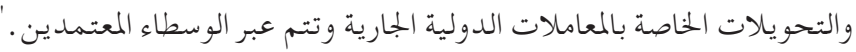

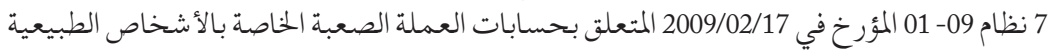

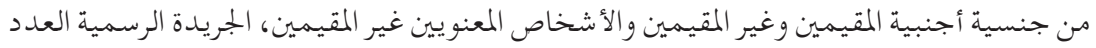
25 الصادرة بتاريخ 2009/04/29. 
الجزائر مهما كان شكله عن طريق تصريح المستثمر في البطاقة الوصفية للاستثمار المقرر

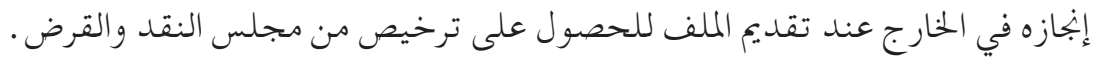

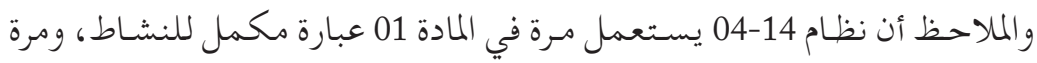

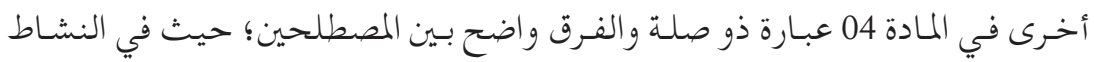

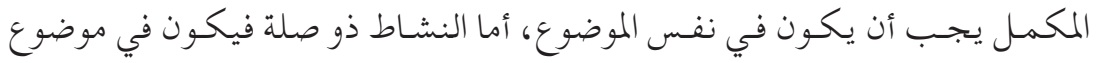
مختلف، ولكنه يرتبط بالنشاط الأصلي.

\section{3- تجاوز نسبة المساهمة في الحارج 10 بالمئة من الأسهم مع حق الثصويت :}

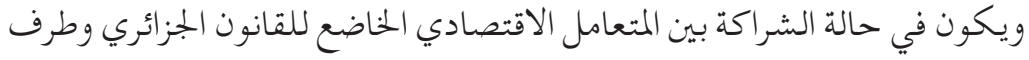

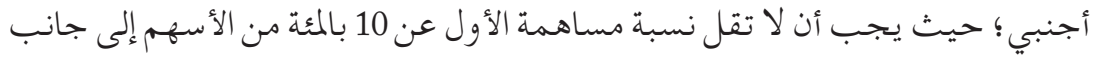

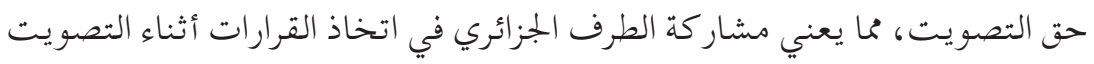

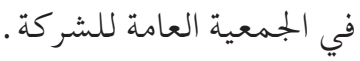

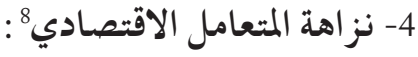

\section{وهذا بتوفره على شهادة سلبية بعدم تسجيله في كل من :}

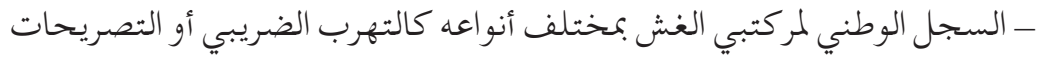

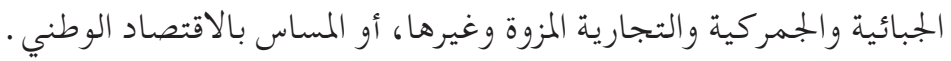

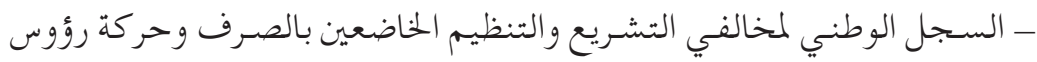

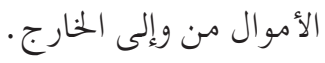

5- تحقيق إير ادات منتظمة من الصادرات واستمر ارية ميزان المدفوعات : أي أن المتعامل الاقتصادي يجب أن يقوم بعمليات تصدير للمنتجات التي يريد

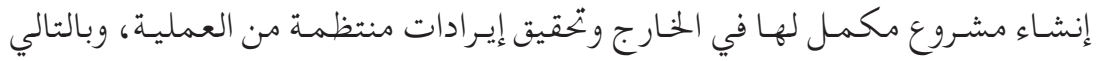

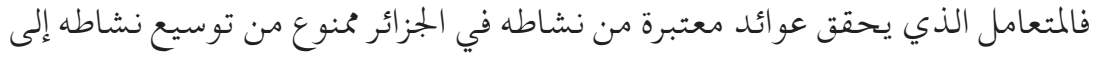

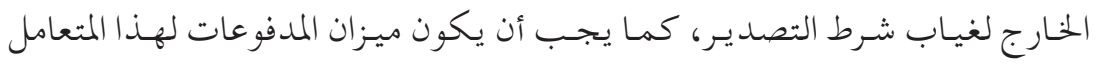

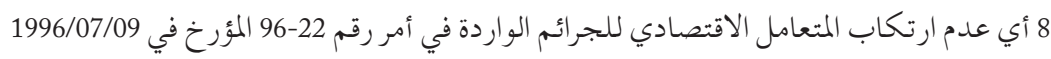

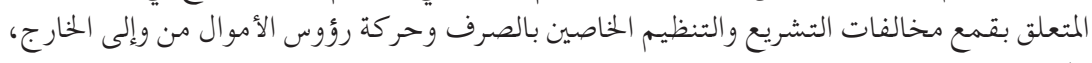

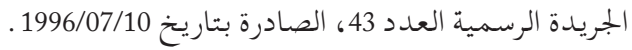


متـوزان ومستمر أي أنه دائن وليسس مدين لأنهه لا يمكن أن نتصور متعامـلا اقتصاديا

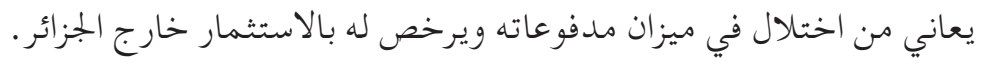
ثانياً : الشروط الحخاصة بالدول المستضيفة للاستثمار الجزائري 1- شفافية النظام الجبائي للدول المستضيفة :

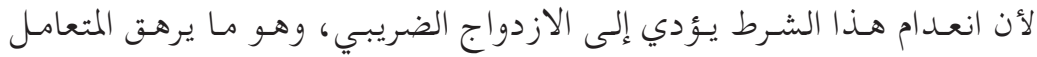

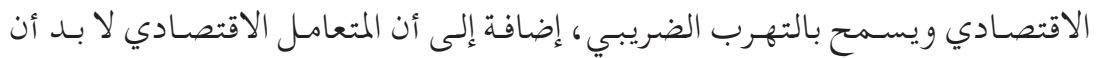

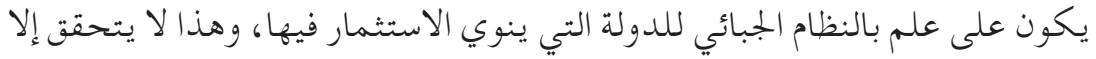

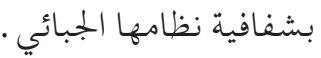

2- التعاون الدولي في المجالين القضائي والجبائي وإمكانية تبادل المعلو مات وهو شرط يسـمح بالتنسـيق الدولي في مختلف الجرائم الاقتصاديـة كالتحويل

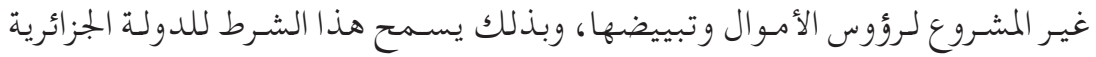

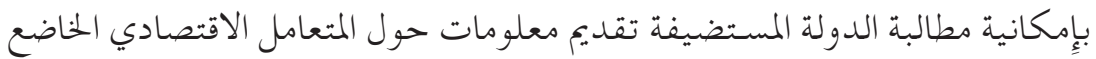

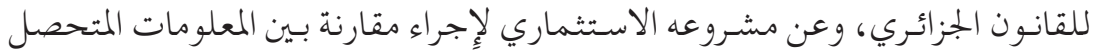

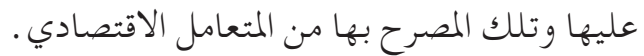

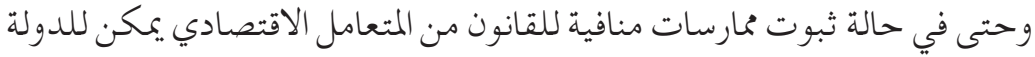

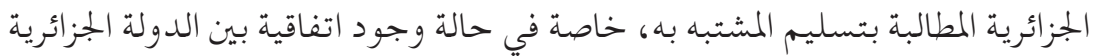

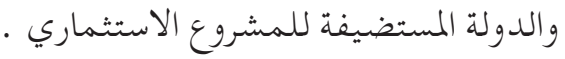

$$
\text { 3- السماح بعمليات الترحيل لرؤوس الأموال : }
$$

أي يسـمح النظام القانوني للدولـة المضيفـة للاستثمار تحويل فوائـد الاستثمار ومحصلات البيع أو تصفية الاستثمار .

المبحث الثاني : تكريس التحكيم الدولي من خلال الاتفاقات الدولية والمثــاكل الناجمة عنه

ونتعـرض لتنظيمـه في الاتفاقيـات الدوليـة الثنائيـة والمشـاكل والصعوبـات التي تعترضه على النحو التالي : 


\section{المطلب الأول : تكريس التحكيم الدولي من خلال الاتفاقات الدولية الثنائية}

يمكن تعريف التحكيم بأنه وسيلة خاصة للتقاضي تقوم على اتفاق يعهد الأطراف

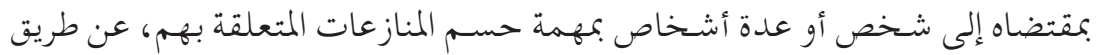

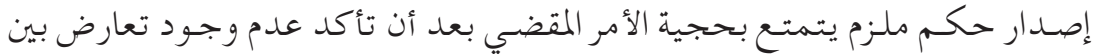

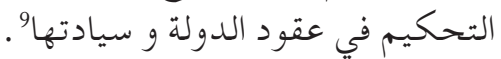

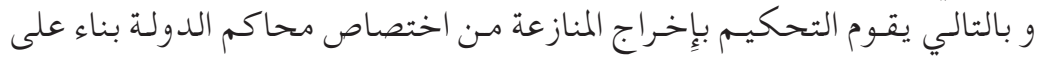

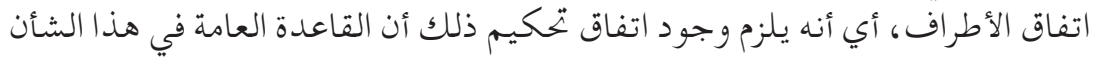

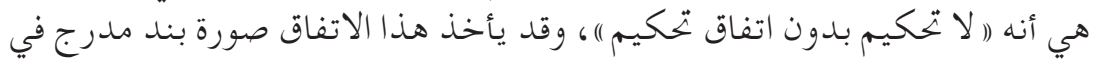

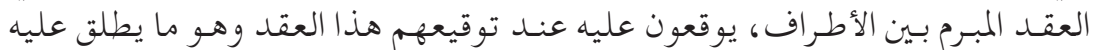

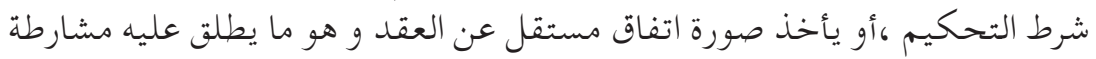
التحكيم .

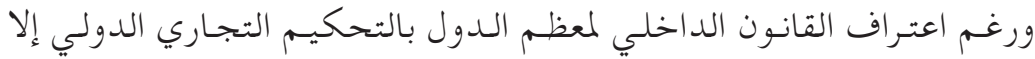

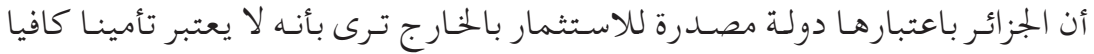

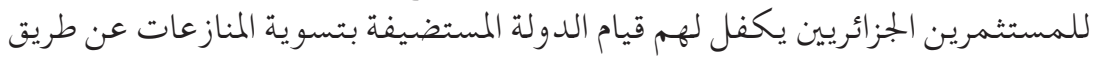

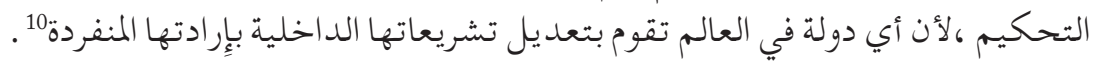

\section{أولا : الاتفاقيات الدولية الثنائية في مجال الاستثمار}

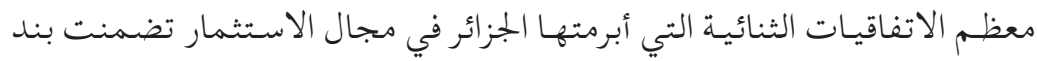

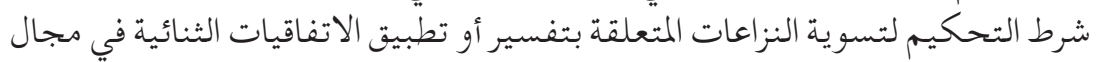

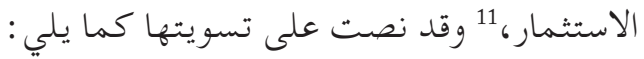

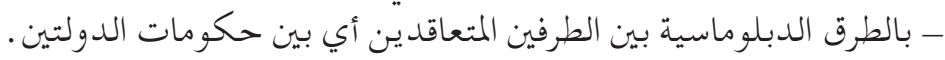

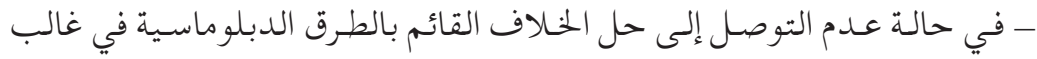

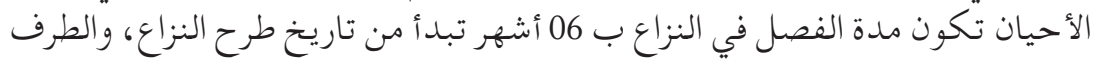

9 OLIVIER Cachard, «Droit du commerce international», L.G.D.J , p. 406.

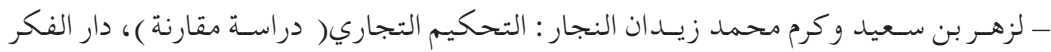

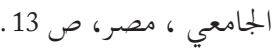

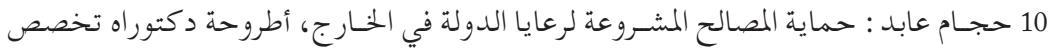

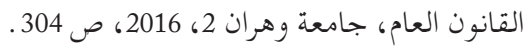

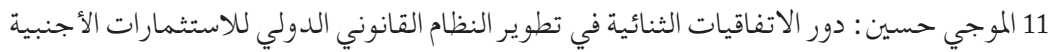

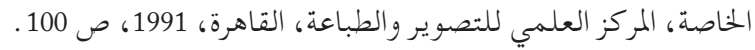


الأكثر تضررا يمكنه عرض النزاع على محكمة تحكيمية خاصة تولت الاتفاقية تحديد

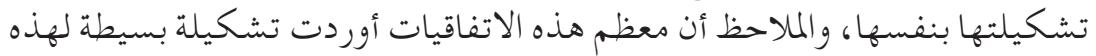

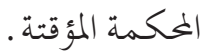

وقـد نصـت كل الاتفاقيـات الثنائيـة التي أبرمتها الجزائر مـع دول أخرى في مجال

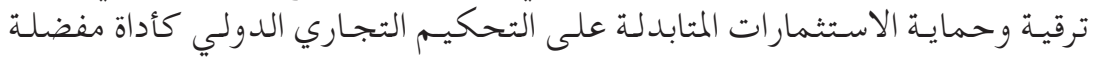

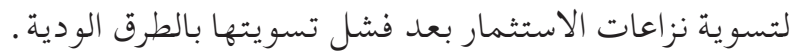

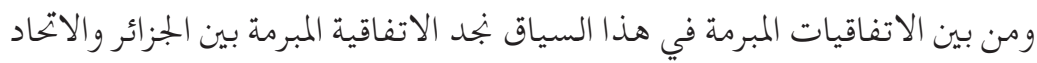

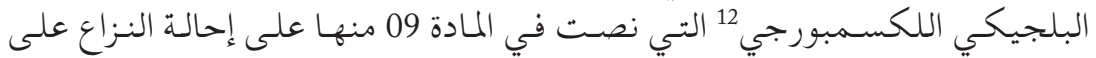

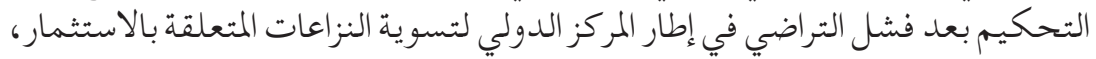

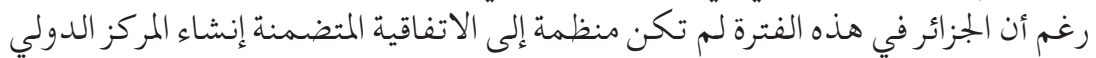

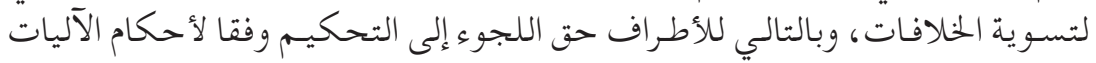

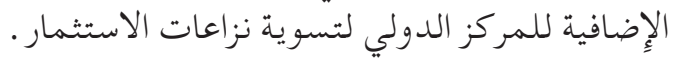

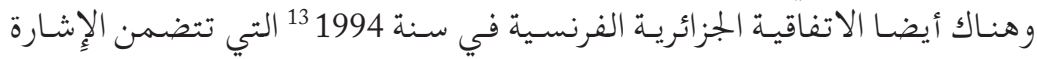

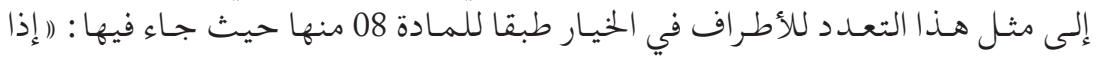

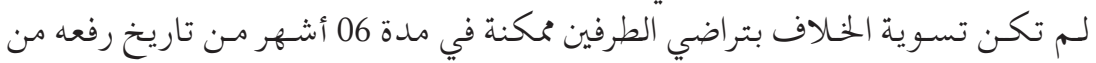

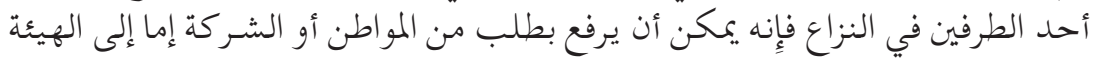

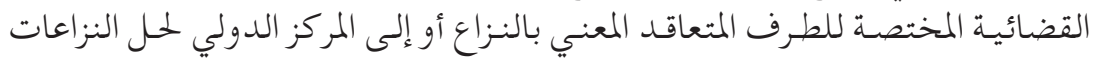

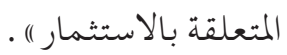

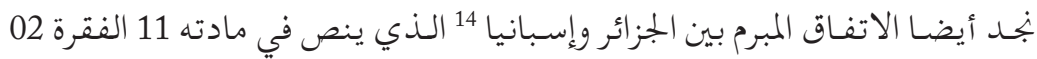

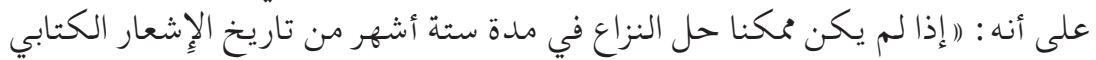

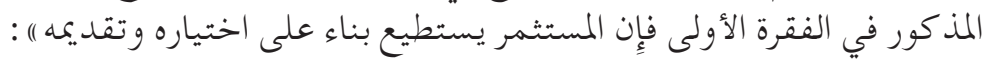

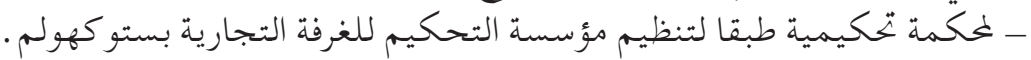

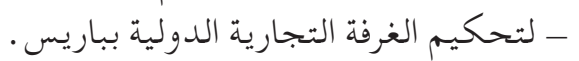

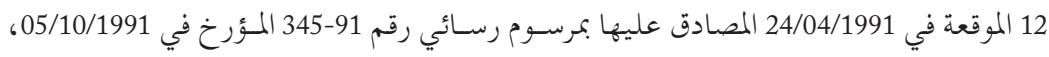

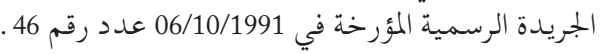

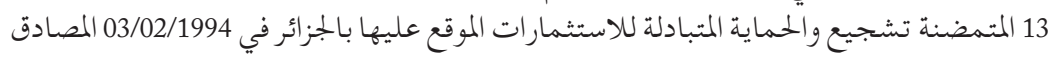

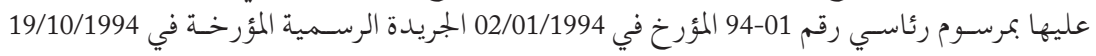

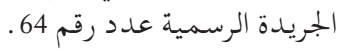

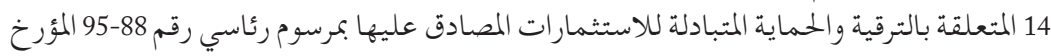
في 25/03/1995 الجريدة الرسمية عدد رقم 23 لسنة 1995. 


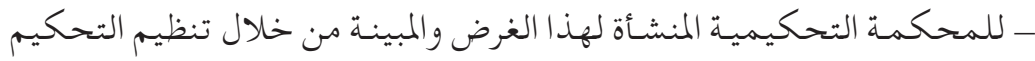
للجنة الأم المتحدة للقانون التجاري الدولي.

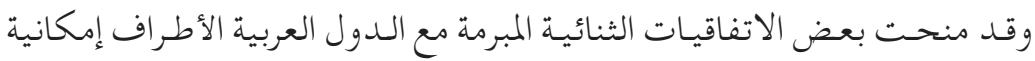

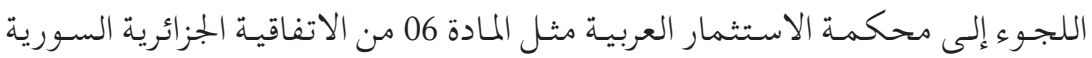

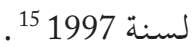

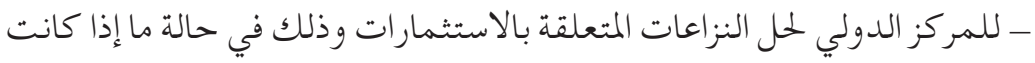
كلا الدولتين الطرف في هذا الاتفاق انضمت إليه ). . ثانياً : مبررات اللجوء إلى التحكيم التجاري الدولي

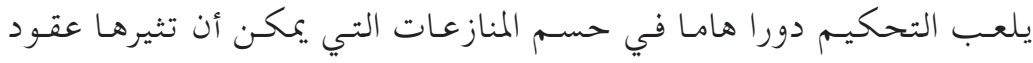

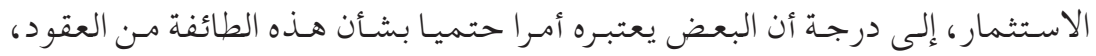

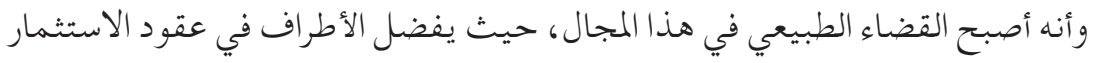

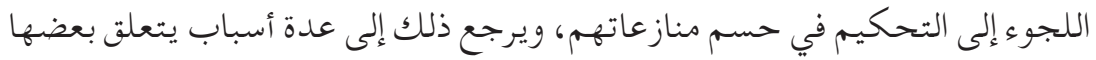

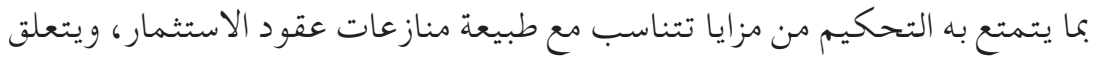

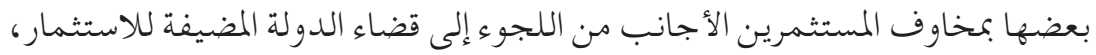

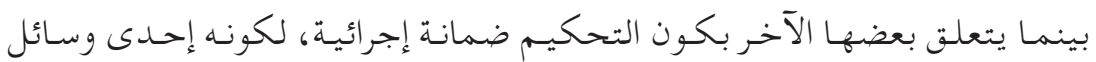

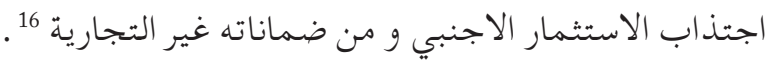

\section{1- مز ايا التحكيم تتناسب مع طبيعة منازعات عقود الاستثمار}

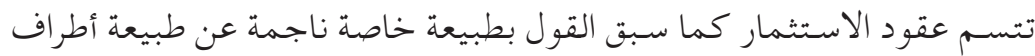

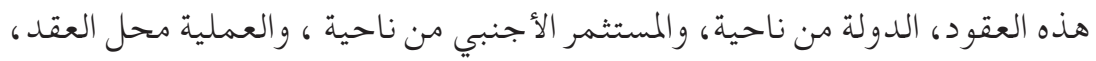

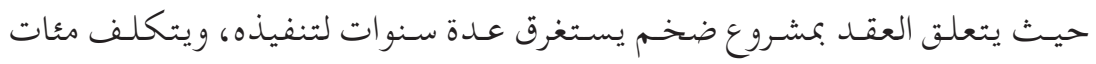

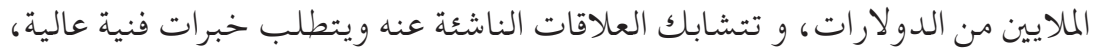

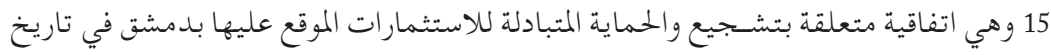

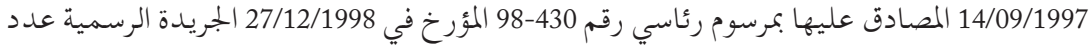

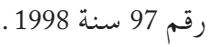
16 دـ مراد محمود المواجدة : التحكيم في عقود الدولة ذات الطابع الدولي، دار الثقافة للنشر

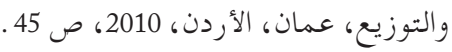




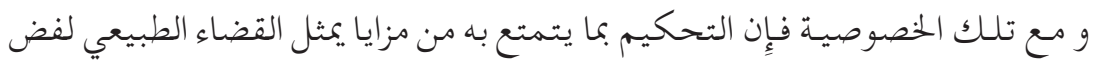

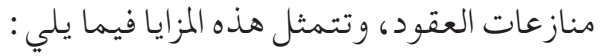

\section{2- السرعة في الاجراءات}

الفصل في النزاع في أوقات قياسية مقارنة مع تلك الاجراءات المتبعة إذ أن مرونة

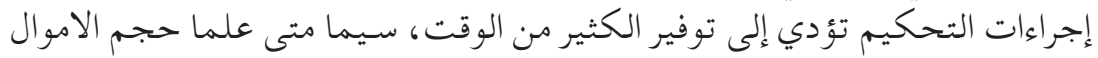

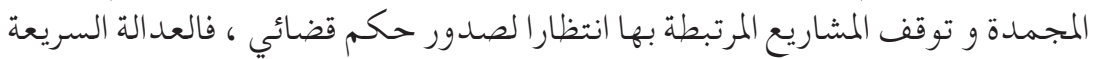

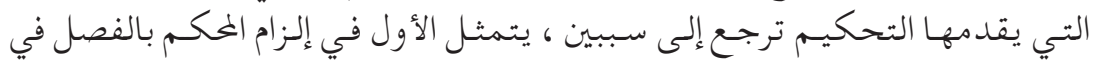

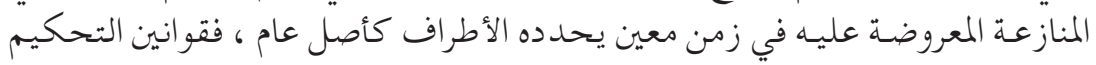

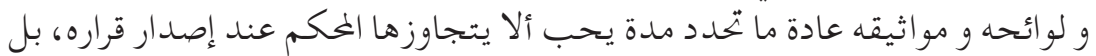

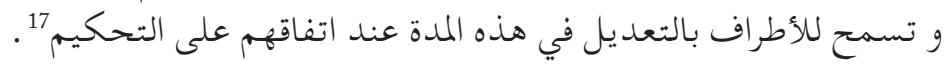

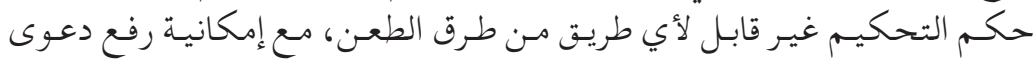

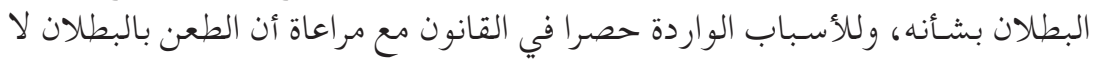
يوقف تنفيذ حكم التحكيم كأصل عام. وأصبح التحكيم كذلك مطلبا من المطالب الأساسية للتجارة العالمية والإِستثمار

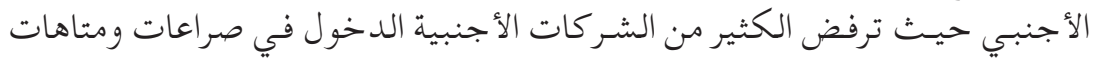

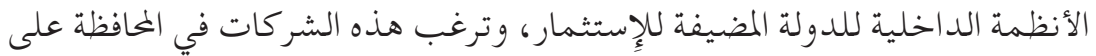

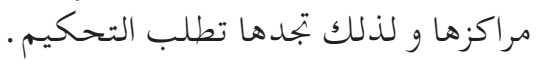

\section{3- سرية التحكيم التجاري الدولي}

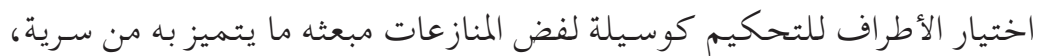

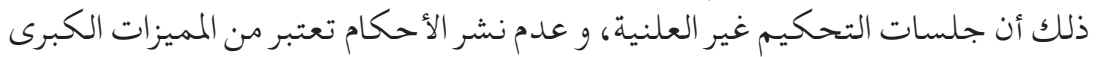

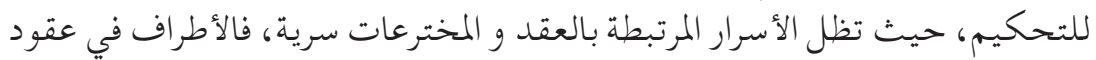

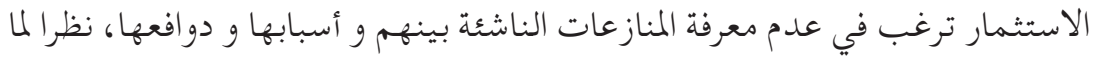

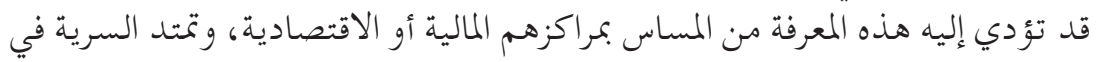

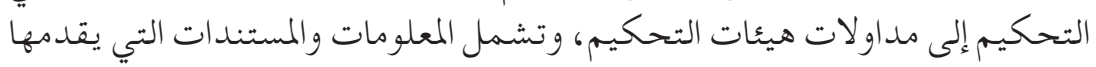

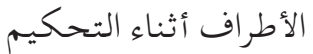

17 د. عاطف محمد الفقي : التحكيم التجاري المتعدد الأطراف ( دراسـة مقارنة )، دار النهضة العربية، القاهرة، مصر محمد 2007، ص ص 22. 


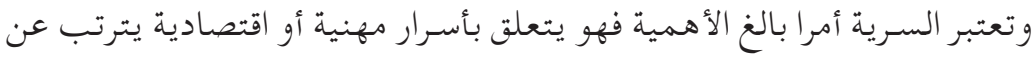

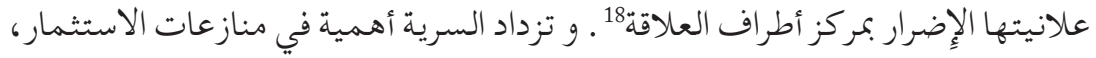

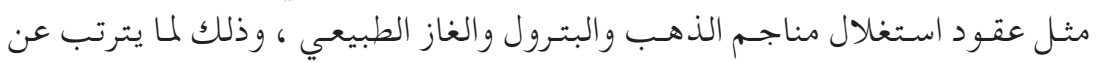

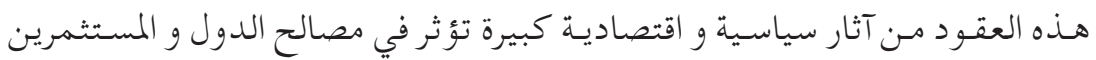

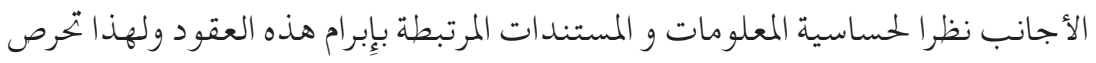

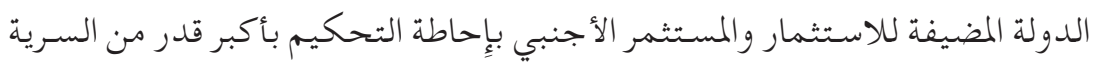

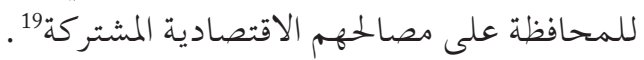

\section{4- عدم الثقة بالقضاء الوطني للدول المضيفة للاستثمار}

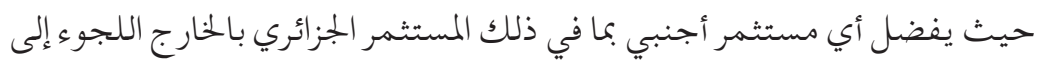

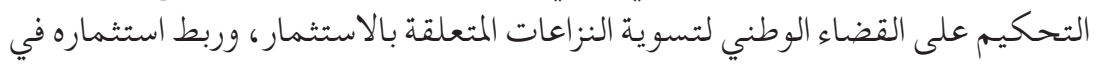

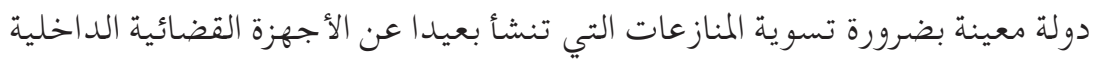

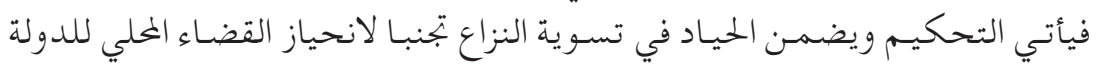

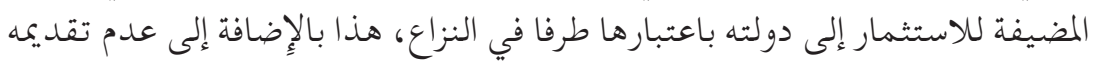

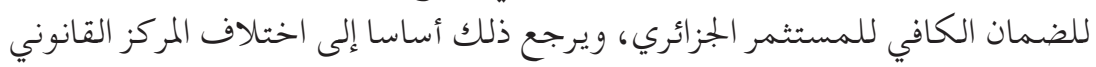

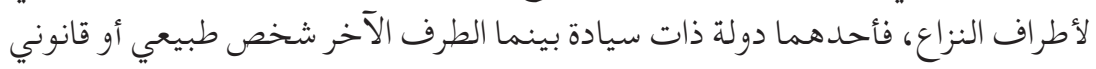

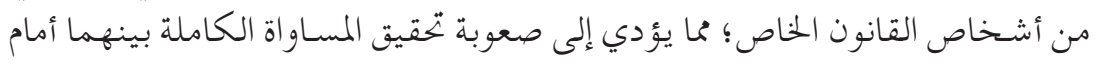

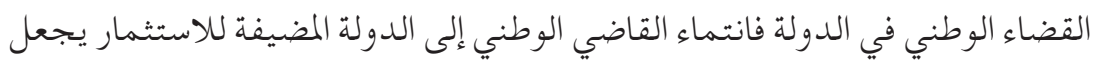

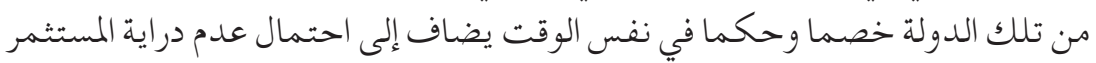

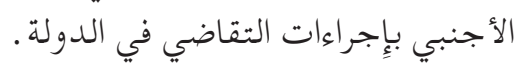

المطلب الثاني :مشـاكل التحكيم التجاري الدولي كآليـة لتفعيل الأمن القانوني للاستثمار الجزز ائري بالحخارج

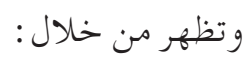

18 دـ أحمد عبد الله المراغي : قواعد المحاكمة والتعاون الدولي في جرائم الاستثمار، دار الفكر

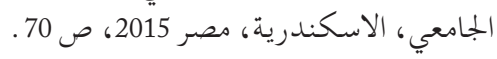
19 د. هاني محمد كامل المنايلي : اتفاق التحكيم وعقود الاستثمار وعقود الاستثمار البترولية-

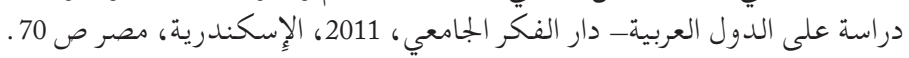




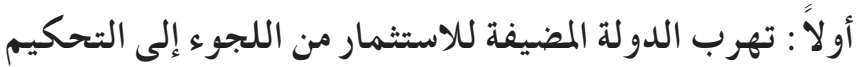

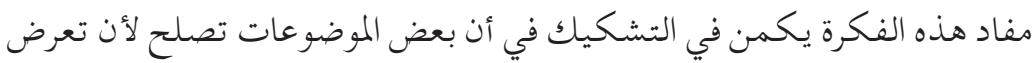

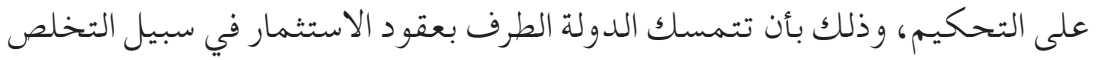

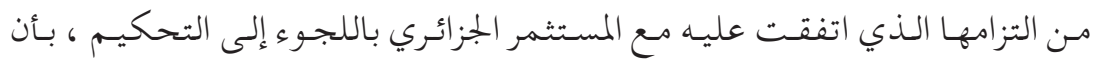

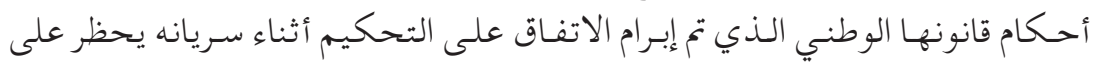

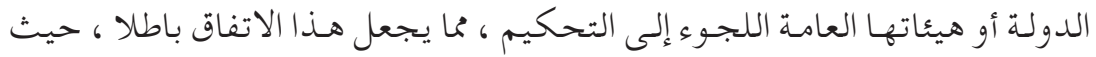

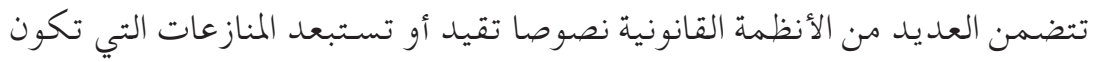

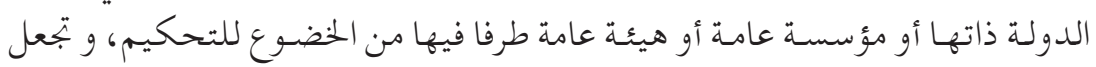

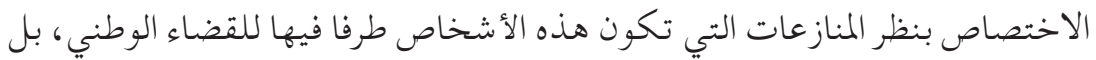

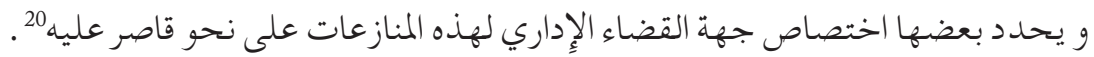

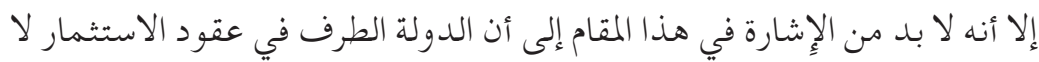

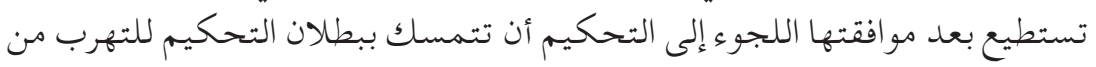

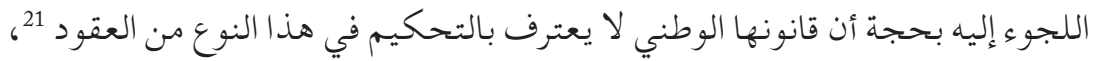

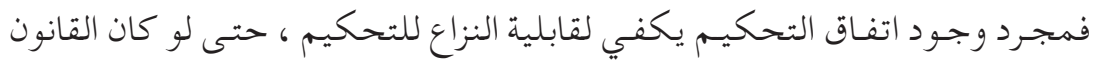

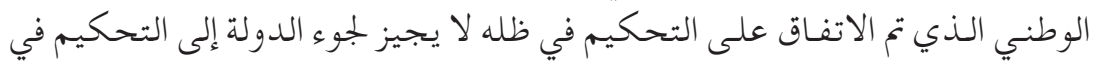

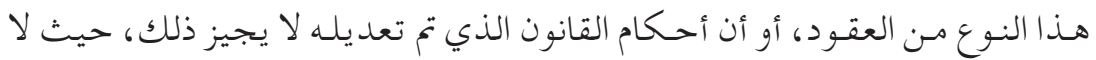

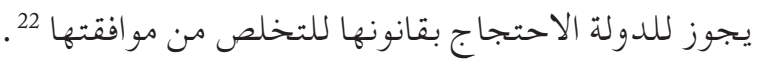
ثانياً : محاولة استثناء قرارات السيادة من التحكيم :

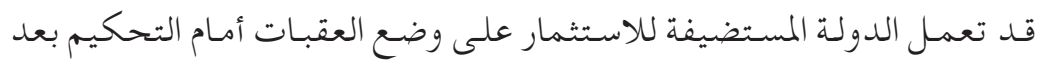

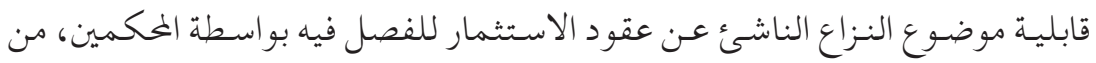

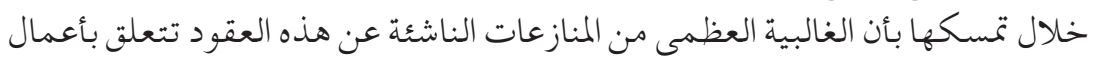

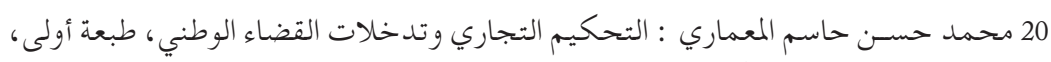

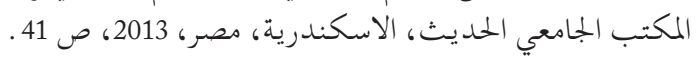

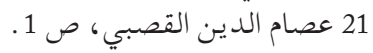

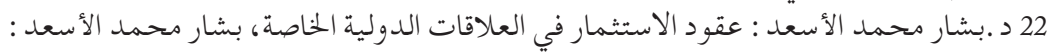

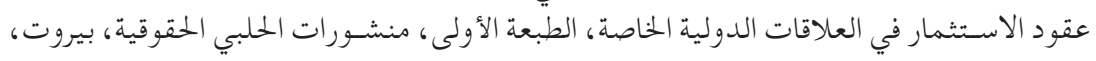

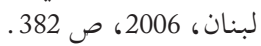


صادرة عن الدولة بصفتها سلطة عامة سيادية، و التي لا تقبل الخضوع إلى التحكيم،

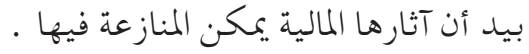

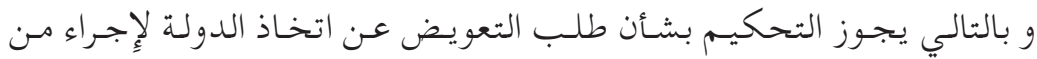

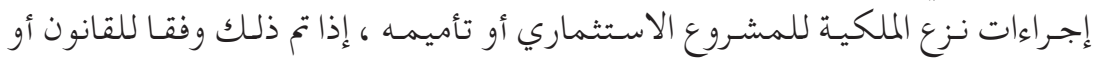

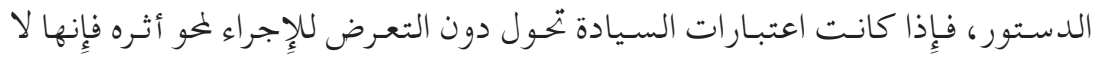

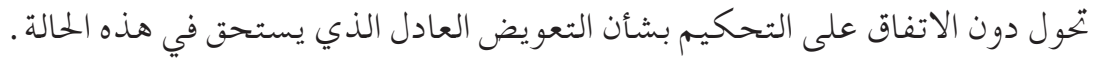

\section{ثالثاً : مشكل تنفيذ حكم التحكيم}

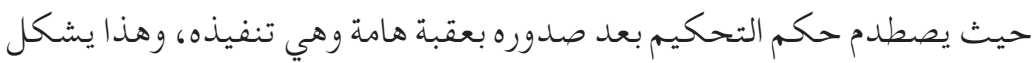

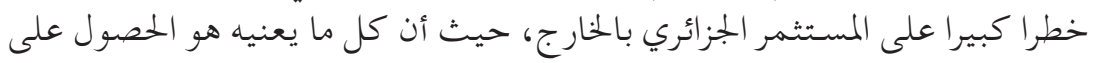

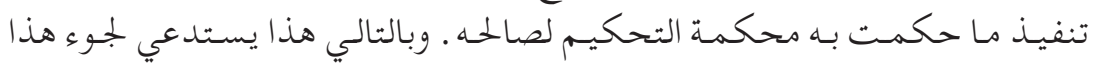

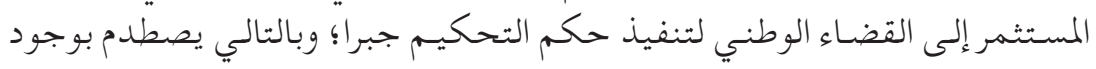

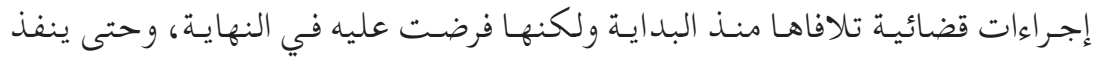

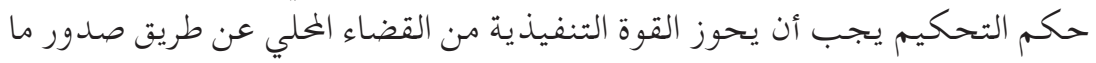

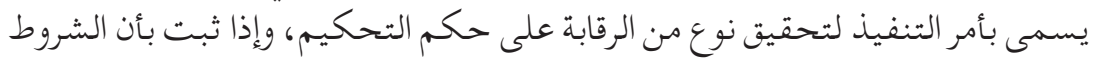

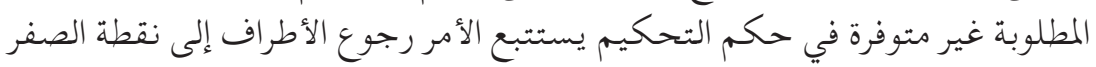

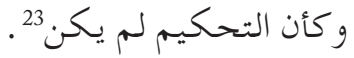

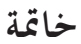

من خلال هذا البحث البسيط توصلنا إلى مجموعة من النتائج والمقترحات التي

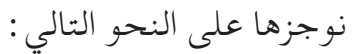

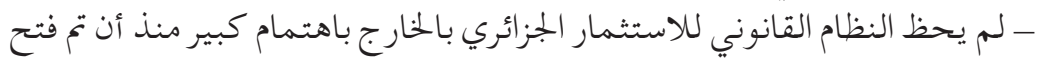

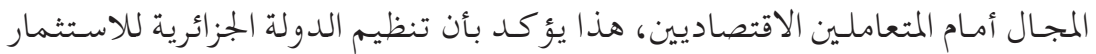

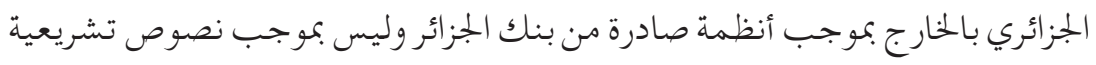

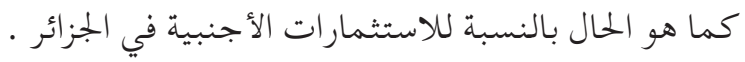

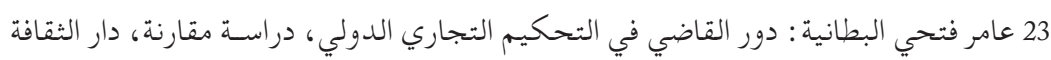

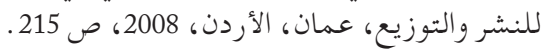
السيد محمود التحيوي : تنفيذ حكم التحكيم، الطبعة الأولى، دار الفكر الجامعي، الاسكندرية، 
- أن الدولة الجزائرية بذلت مجهودات جبارة من أجل توفير الحماية لمستثمريها

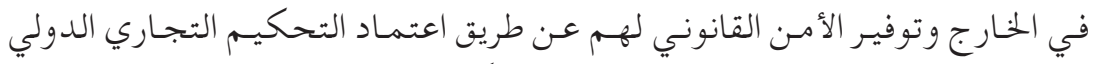

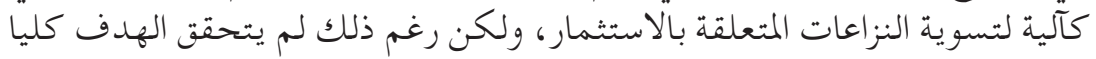

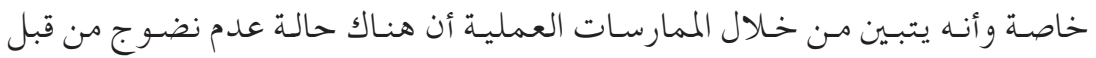

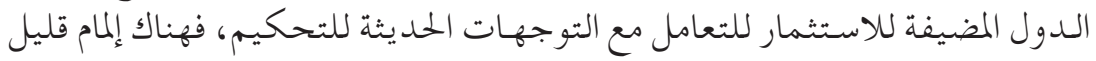

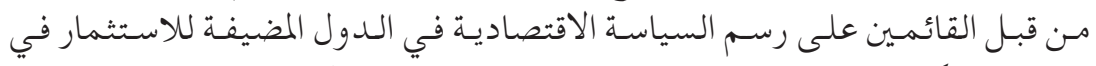

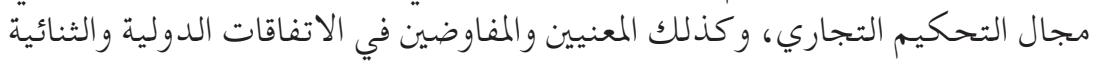

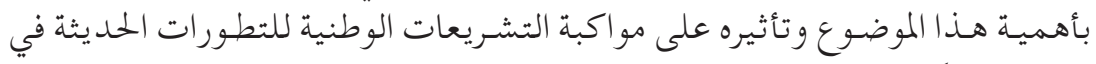

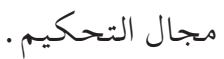

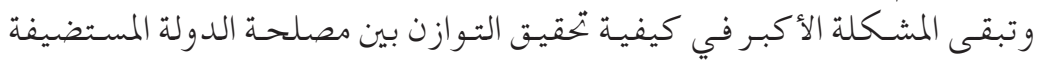

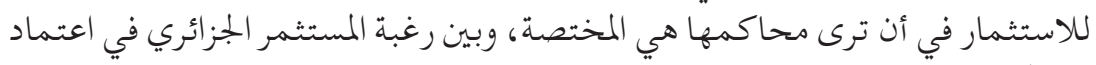

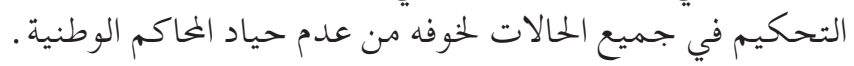





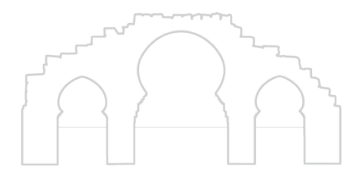

Reseñas y comentarios bibliográficos 



\begin{abstract}
Óscar Abenojar, Ouahiba Immoune y Fatima-Zohra Menas, La princesa cautiva y el pájaro del viento. Mitos y cuentos del norte de Argelia, Madrid, Verbum, 2015, 224 pp. [ISBN: 978-8490742228]
\end{abstract}

Cuarenta y ocho son los relatos que componen la antología La princesa cautiva y el pájaro del viento. Mitos y cuentos del norte de Argelia, una serie de fábulas y cuentos reunidos y catalogados directamente de las narraciones orales en Argelia y, posteriormente, traducidos por primera vez a lengua castellana. La selección de relatos, la mayoría breves y de lectura amena, transmiten a través de las situaciones e historias que viven sus personajes una moraleja vital que, sin duda, supone una fuente importante de enseñanza y transmisión (el ámbito íntimo y de recogimiento familiar) de una sapiencia tradicional y de los valores de la cultura en la que se dan estos relatos.

Las narraciones de Mitos y cuentos del norte de Argelia fueron cuidadosamente registradas, durante casi seis años de trabajo de campo, a lo ancho y largo del territorio argelino: desde la costa mediterránea hasta los apartados oasis del septentrión argelino, por lo que las muestras de literatura oral obtenidas - teniendo en mente el elevado nivel de heterogeneidad tanto en términos geográficos como sociológicos y etnográficos de estos lugares, donde conviven, además, hablantes de lengua árabe y bereber- resultan de lo más representativas. Algunos de estos relatos ya habían sido documentados (con ciertas variaciones o versiones que el prólogo del libro se encarga de explicar en detalle), mientras que muchas otras de las narraciones registradas son historias únicas de las que no había constancia documental hasta la fecha. Estos relatos, ciertamente, tienen un extraordinario interés etnográfico: la hibridación de las tradiciones literarias europeas, orientales, árabes y amazigh, que han dado forma a estos cuentos de esencia argelina, constituye un objeto de investigación relevante para los estudios de literatura comparada. En este sentido, dado el valor cultural intrínseco de esta obra y su relevancia para el folklore argelino, tal vez se echa en falta una edición bilingüe 
que contenga la transcripción de los relatos recogidos en la lengua de origen, con el fin de poder realizar, asimismo, trabajos lexicográficos o lingüísticos.

La estructura comprehensiva del libro - que agrupa los relatos según su contenido sea de carácter etiológico, según sean fábulas o cuentos de animales, cuentos maravillosos, o cuentos realistas y de ingenio- facilita al lector introducirse en el imaginario de la sabiduría popular argelina. Enmarcada en la sección de cuentos maravillosos, se encuentra el vigésimo segundo relato, que da nombre a la colección: La princesa cautiva y el pájaro del viento, una fábula centrada en la reflexión sobre la lucha por la libertad y su significado.

Mención especial requiere el prólogo de esta obra: una crítica bien fundamentada, pese a su limitada extensión, donde se realiza una reflexión objetiva sobre la postura tradicional que ha venido considerando que los cuentos argelinos son, en realidad, una herencia oriental o una suerte de mezcolanza de cuentos importados desde Europa, en lugar de considerarlos como una producción genuina propiamente dicha, resultado de la interpenetración de diferentes sustratos culturales y que revisten elementos diferenciadores propios. En consonancia con esta postura, a lo largo del prólogo se hace un análisis comparativo del relato cabilio La muchacha que se convirtió en ogresa, donde se establecen paralelismos entre éste y algunos relatos griegos, indios e incluso australianos, pero sin perder de vista que el cuento argelino posee entidad propia. El análisis, que se hace en el preámbulo sobre estos mitos y cuentos del norte de Argelia, estudia, en busca de sus orígenes e influencias, las raíces subsaharianas que algunos de ellos poseen (como ocurre con el cuento Papá tortuga, la rana y la serpiente, que guarda similitud con otro relato del Cuerno de África), y compara, también, las versiones hispánicas del cuento argelino Los animales de la granja y las fieras.

Sin duda, La princesa cautiva y el pájaro del viento. Mitos y cuentos del norte de Argelia supone un volumen que contiene, en términos cualitativos y cuantitativos, una variedad muy representativa de relatos tradicionales de gran valor literario, tanto por su contenido de relevancia para los estudios filológicos, etnógrafos y folcloristas, como por los elementos culturales, sociológicos y lingüísticos que envuelven a esta amalgama 
de fábulas y cuentos. Esta obra supone, en esencia, un gran aporte que impulsa el esfuerzo en favor de la recuperación, sistematización y difusión de la literatura argelina de tradición oral, insignia de su patrimonio humano multilingüístico e intercultural.

Antonio Torres Fernández

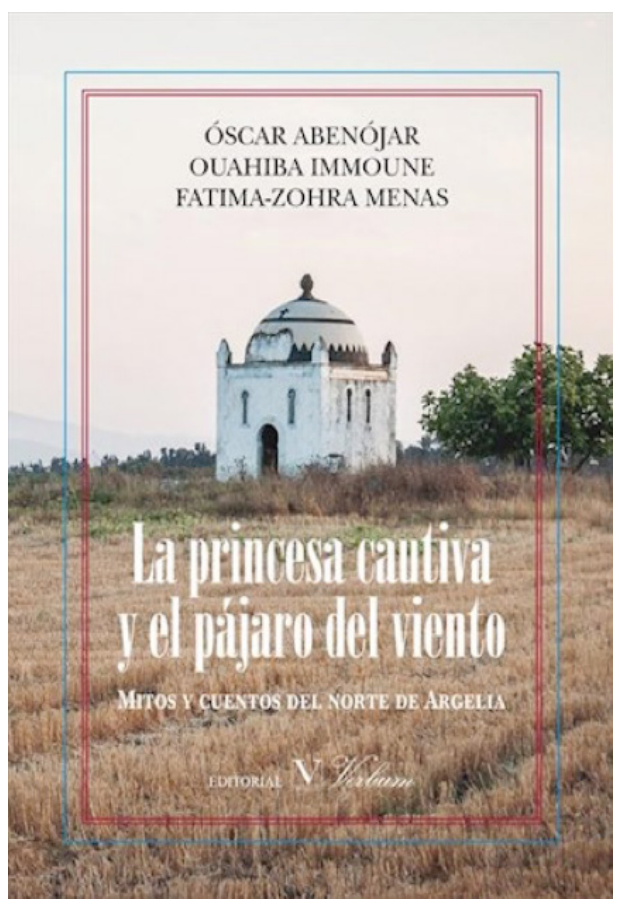





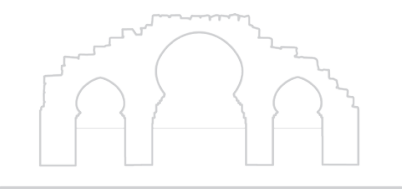

Biblioteca 



\title{
LA HISTORIA DE HARÚN AL-RASHID
}

\author{
Narrada por Mohammed Kandouci (I925-2008).

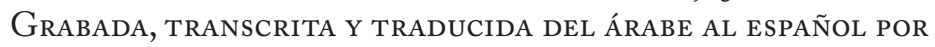 \\ LaRedJ Kandouci, PROFESOR DEL \\ INSTITUTO DE TRADUCCIÓN E INTERPRETACIÓN DE LA \\ Universidad de Argel-2
}

\section{Nota PRELIMINAR}

Mohammed Kandouci nació en la localidad de Beniane, cerca de la ciudad de Saïda, en Argelia, el día 8 de mayo de 1925. Cuando era muy joven perdió a su padre, y no tuvo la oportunidad de ir jamás a la escuela, por la sencilla razón de que vivía en las afueras del pueblo. Trabajó durante toda su vida como cargador y descargador de sacos de cereales. Gentil, humilde, generoso, piadoso, era apreciado por todo el mundo. Falleció en la ciudad de Saïda el 2I de marzo del 2008.

Sabio conocedor de la tradición oral de su región, le gustaba contar sus relatos a sus hijos, nietos y sobrinos nietos, y repetir fórmulas de iniciación y de conclusión que eran las mismas siempre.

La Historia de Harún Al-Rashid se la contó a su sobrino Laredj Kandouci (quien la grabó entonces) en el año 1986.

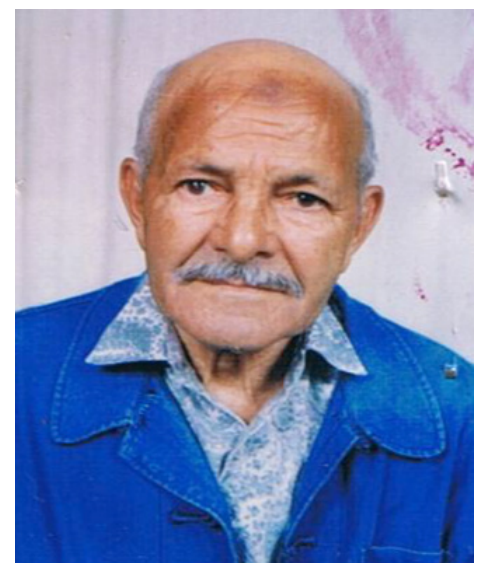


Érase que se era. Había albahaca y lirios en el regazo del Profeta, con Él sean la oración y la paz.

Érase una vez un hombre que decidió ir a la Meca. Como poseía siete jarras llenas de oro, las cubrió de una gruesa capa de sal y se las confió a un vecino judío.

Éste le dijo:

-Deja tus jarras y marcha tranquilo, que aquí estarán seguras.

Una noche, mientras la mujer del judío preparaba la cena, ella se dio cuenta de que no había sal en casa. Le anunció entonces a su marido que iba en busca de sal. Él pensó en los bienes del musulmán y le dijo:

-Encontrarás sal en las jarras: coge un poco, compraremos mañana y llenaremos las del musulmán como estaban antes.

— ¿Hablas en serio? —añadió ella.

-Sí - contestó.

Entonces fue, metió su mano en una de las jarras y notó que contenía una gran cantidad de oro. Avisó a su marido, quien, sobre la marcha, fue vaciando las jarras y llenándolas de sal.

Tras varios años, el musulmán volvió a su hogar. Se presentó en casa del judío para recuperar sus jarras. Al revisarlas, se dio cuenta de que contenían solo sal.

Fue entonces a quejarse al sultán:

-Majestad, antes de ir a peregrinar, confié siete jarras llenas de oro al judío. Y a mi regreso me las ha devuelto llenas de sal.

El sultán convocó al judío y le preguntó:

—_Dónde está el oro del musulmán?

—Majestad — respondió—, el musulmán me había confiado solo sal. Aquí está la sal.

Harún Al-Rashid, todavía joven en aquella época, estaba jugando con los niños de su edad. Oyó la discusión que estaba teniendo lugar y propuso actuar con justicia:

- Hagamos venir a dos expertos — dijo. Uno reconocerá la presencia de la sal y el otro la del oro.

Se cumplió entonces lo que pedía. En efecto, el primer experto dijo: 
-Arriba estaba cubierta de sal; sin embargo no puedo adivinar lo que contenía en la parte de abajo.

El segundo dijo:

-Abajo estaba repleta de oro; pero no puedo averiguar lo que contenía en la parte de arriba.

Aquel peritaje contentó al Sultán, quien desposeyó al judío y devolvió su riqueza al musulmán. Este último recuperó sus bienes gracias a Harún Al-Rashid.

El tiempo pasaba, y Harún Al-Rashid crecía. Una noche tuvo un sueño: vio siete espigas verdes y siete espigas secas.

Por la mañana, al despertar, fue a ver a un sabio. Le interpretó el sueño para él y le reveló lo siguiente:

—En tu vida conocerás siete años de miseria y siete años de riqueza. $¿$ Quieres, pues, vivir los años amargos en tu juventud? ¿O mejor prefieres dejarlos para más tarde?

Harún Al-Rashid reflexionó durante unos instantes. Y decidió vivir los años de miseria en su juventud. Preparó entonces una mula, llenó su albarda de piezas de oro, cogió los alimentos necesarios y se marchó.

Viajó de una ciudad a otra sin cesar. Una mañana decidió hacer un alto cerca de una fuente y pensó:

-Aquí me lavaré, beberé y haré que mi mula abreve.

Apenas había dado la bestia dos o tres pasos cuando cayó por un barranco con toda la carga que llevaba. El buen hombre se vio súbitamente reducido a la pobreza.

Al llegar a una ciudad vecina observó a un carnicero que vendía despojos. Los compró y puso sobre su cabeza un montón de grasa a modo de turbante, pues no tenía nada con qué cubrirse.

A continuación comenzó a vagabundear por la ciudad y dejó que se secasen los despojos sobre su cabeza.

Una vez encontró un trabajo en un mesón. A la gente le gustaba la comida que preparaba. Gracias a él hizo el dueño fortuna.

Después se fue a trabajar con un vendedor de churros. Este también preparaba quintales de harina y lo vendía todo. Una ventana del palacio del Sultán daba a una piscina en la que sus hijas se bañaban. 
Un día Harún Al-Rashid se desnudó, se quitó las tripas que le cubrían y saltó al agua.

Una de las hijas del Sultán le observó. Se maravilló de que Harún al-Rashid fuese tan hermoso. Tras el baño se vistió, se colocó de nuevo las tripas y volvió a su trabajo.

Las siete hijas del Sultán habían crecido, pero aun así nadie les había propuesto matrimonio. Visitaron a una mujer sabia y le expusieron su problema. Les dijo ella:

-Comprad siete cuchillos y siete manzanas, y dejadlos encima de la mesa donde vuestro padre tiene por costumbre comer.

El Sultán llegó a su casa al mediodía, comió y volvió a su trabajo. La visión de los siete cuchillos y de las siete manzanas le había perturbado. Fue a ver a un sabio, y él le hizo saber que sus hijas tenían ganas de casarse.

Sin demorarse informó el Sultán al pueblo del deseo de sus hijas. Aquéllos que aspirasen a contraer matrimonio con ellas no tenían más que lavarse los turbantes y presentarse en palacio. Seis hijas del Sultán lanzaron seis manzanas a seis varones jóvenes de su elección; sólo quedaba la séptima.

En el pueblo, únicamente el ayudante del churrero faltaba por presentarse. El Sultán se sentía inquieto, y preguntó quién faltaba.

- Señor — le respondió la gente-, sólo queda el ayudante del churrero.

- Hacedlo venir — dijo él. Acaso quiera Alá enriquecerlo.

Cuando el pobre hombre llegó, la hija del Sultán le arrojó su manzana. Él la recogió, la olfateó y la guardó. El Sultán anunció a sus futuros yernos la celebración del matrimonio.

-No - le advirtió Harún Al-Rashid al Sultán. Antes de las bodas, aseguraos de antemano de lo que valen los futuros maridos de vuestras hijas. Fingid que estáis enfermo y pedidles agua del monte Waq-Waq.

Éste, como el pico de un pájaro, se abría y se cerraba continuamente, y nadie en el mundo podía sacar de allí su agua.

El Sultán hizo saber su deseo a sus yernos, y ellos marcharon a cumplir la difícil prueba. Él no cesaba de elogiar a sus seis futuros yernos, sin conceder la menor importancia a Harún Al-Rashid. De modo que le ofreció un caballo flaco. Los otros cobraron ventaja y no cesaban de burlarse de él. 
Pasadas unas horas, Harún Al-Rashid hizo girar un anillo mágico que poseía y pidió un caballo blanco y una túnica blanca. Los adelantó en un abrir y cerrar de ojos.

Cuando los otros yernos lo vieron, se dijeron entre sí:

-Ésta es la persona que nos ayudará en nuestra tarea.

Y se dirigieron hacia él.

—¿Qué es lo que queréis? - preguntó él.

- Somos los futuros yernos del Sultán. Está enfermo y nos ha pedido agua del monte Waq-Waq.

- Sería fácil conseguirla, aunque para eso debéis darme los lóbulos de vuestras orejas.

- Ah, eso no es problema - le respondieron-, porque llevamos turbantes que tapan nuestras orejas. Nadie se dará cuenta de nada.

Sacaron un cuchillo, se cortó los lóbulos de las orejas, los ensartó con un hilo y fue a buscar el agua para ellos.

A su vuelta se la pidieron para llevársela al Sultán. Él se quedó detrás de ellos. Cuando se marcharon, volvió a ponerse sus vestidos rotos y los siguió hasta el palacio.

El Sultán se quedó impresionado cuando vio que los futuros maridos de sus hijas habían cumplido una tarea tan difícil.Juntos trasnocharon y se divirtieron, mientras Harún Al-Rashid pasaba la noche solo.

Algunos días después solicitó el Sultán una prueba aún más difícil:

- Mis yernos queridos - les dijo-, vamos a celebrar el matrimonio cuando me traigáis la leche de una leona metida en la piel de su cachorro.

Los seis yernos partieron, y el séptimo les siguió como de costumbre, sin que dejasen de burlarse de él. En cuanto se alejaron un poco, hizo girar su anillo y se presentó ante ellos con una túnica roja sobre un caballo rojo.

Se alegraron de verlo, fueron a su encuentro y le pidieron lo que deseaban. Él aceptó otra vez, pero les exigió la punta de los dedos de los pies.

- Cortadlos - le dijeron-; la última vez nos cortasteis los lóbulos y nadie lo ha notado.

Cortó las puntas de los dedos de sus pies, las ensartó junto a los lóbulos de las orejas y las guardó. A continuación hizo girar el anillo y fue en busca de la leche de la leona metida en la piel de su cachorro. Él también se guardó su parte, pero no la mostró. Al final trajo la leche y se la dio a los seis jóvenes. 
El Sultán se sintió satisfecho, y sus yernos fueron bien acogidos. Antes de celebrar el matrimonio, el Sultán les pidió una última prueba.

-Esta vez — les dijo_-, id a buscar manzanas al vergel de Alia Ben Mansur, que habita más allá de los siete mares.

Se pusieron en marcha. El séptimo yerno iba siempre detrás de ellos. Cuando iban un poco más adelante hizo girar su anillo y se encontró delante de ellos, sobre un caballo azul y portando una túnica azul.

Se dirigieron hacia él y le pidieron las manzanas del huerto de Alia Ben Mansur, quien habitaba más allá de los siete mares. Aceptó, y les pidió a cambio las puntas de sus dedos meñiques.

Ellos le entregaron las puntas de sus dedos meñiques. Las ensartó al lado de los lóbulos y de las puntas de los dedos de los pies. Después hizo girar su anillo y fue en busca de las manzanas. Atravesó los siete mares y llegó a la casa de Alia Ben Mansur. La encontró dormida, y observó que en su cabecera y a sus pies había velas encendidas. Entró en el vergel, cogió siete manzanas y cambió las velas.

Dejó un mensaje indicándole quién era, de dónde venía, y quién era el rey de su país. Fue a reunirse con los demás yernos del Sultán y les entregó las manzanas.

Éstos volvieron al palacio, mientras que él iba siempre detrás. E1 Sultán se sintió satisfecho de sus yernos. El matrimonio de sus hijas se celebró entre alegrías durante siete días y siete noches.

Mientras tanto llegaron a su fin los seis meses de sueño de Alia Ben Mansur. Ésta se despertó y se dio cuenta de que había un mensaje para ella y de que las velas habían sido cambiadas de sitio. Convocó a sus soldados y decidió atacar el país de Harún Al-Rashid.

$\mathrm{Al}$ alba, el muecín llamó a los fieles a la oración, y proclamó que "Dios es el más grande" y acabó diciendo:

-Mucha gente nos ataca.

El Sultán se puso furioso al escuchar aquello. Dispuso que se cortase la cabeza del muecín. Dijo entonces a sus guardias:

-Id a buscarlo.

Una vez ante el Sultán, el buen hombre le dijo:

-Majestad, suba al minarete y vea usted mismo lo que pasa.

Desde lo alto del minarete observó el Sultán que todo estaba negro. 
Hizo despertar a sus yernos, a sus soldados y a toda la gente de la ciudad. Harún Al-Rashid combatió también al enemigo. Su coraje dejaba maravillada a la gente. Pero nadie sabía quién era.

Un día fue herido en la pierna. E1 Sultán lo observó. Dijo entonces:

-Aquél que lleva una herida en la pierna es el caballero más valiente.

Encomendó a sus hijas que comprobaran si era uno de sus yernos. En medio de la noche se despertó el séptimo yerno y se puso a curar su herida. La hija del Sultán le reconoció.

Cuando llegó la victoria tiempo después, solicitó Harún el-Rashid al Sultán:

-Majestad, pida a sus yernos que le muestren los lóbulos de sus orejas, las puntas de sus dedos meñiques y las puntas de dedos de los pies.

Así lo hizo, pero los jóvenes respondieron:

- Majestad, es que hemos nacido así.

Harún Al-Rashid sacó de su bolsillo el hilo en el que había ensartado los lóbulos, las puntas de los dedos de los pies y las puntas de los dedos de las manos.

El Sultán dispuso entonces que se cortasen las cabezas de sus yernos. Pero Harún Al-Rashid tuvo piedad de ellos y le pidió que los perdonase.

$\mathrm{Y}$, como se trataba de los últimos instantes de miseria que debía vivir en su juventud, decidió volver a su casa. Recogió a su mujer y se marcharon. Por el camino, cuando llegaron a las proximidades de un barranco, dijo a su mujer:

-En este lugar se despeñó mi mula hace algunos años, con todo lo que llevaba.

Observó que había allí un cabello. Lo retiró y, de pronto, su fortuna volvió a aparecer. Alegre, se dijo:

- La huida de la fortuna rompe las cadenas: basta un hilo para que vuelva.

Recogió sus bienes, volvió a su casa y vivió con su mujer.

Esto es lo que hemos aprendido del Señor. Lo hemos contado a nuestros mejores amigos. 


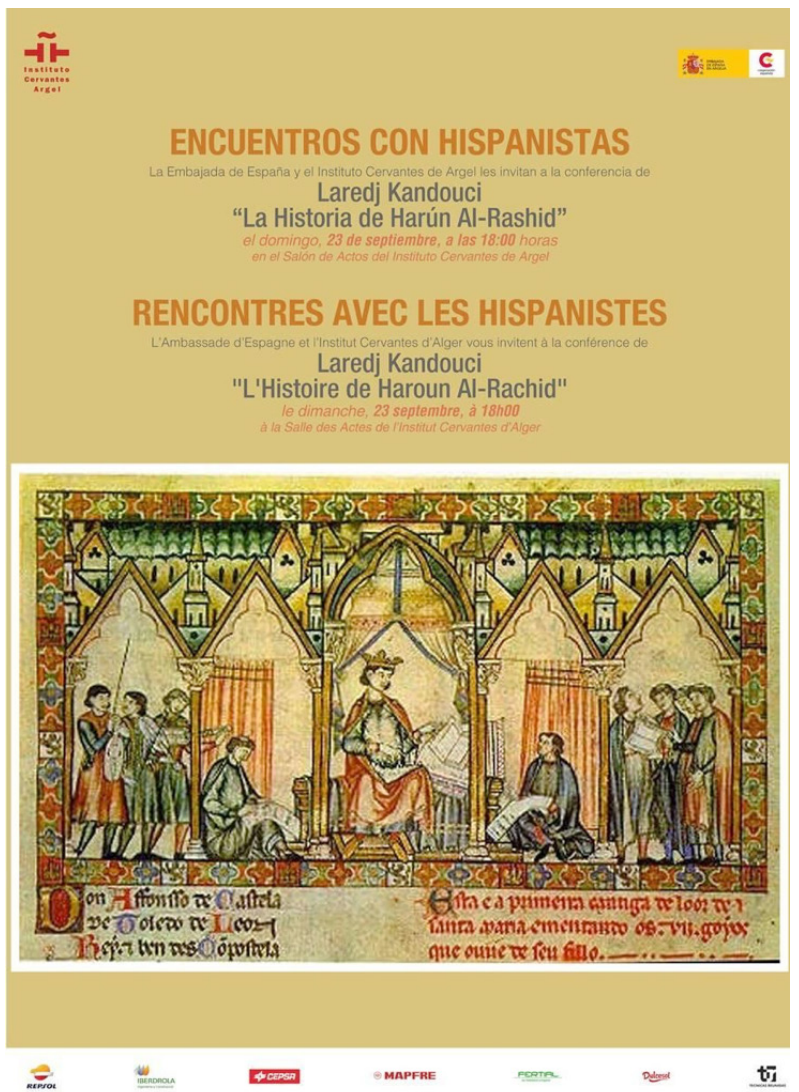

Cartel anunciador de la conferencia que tuvo lugar el domingo 23 de septiembre de 2018 en el Instituto Cervantes de Argel, sobre el texto reproducido en la presente publicación 


\section{EL ROBLE DEL OGRO}

Cuento traducido por Assia Abdi Amamouri

\section{NOTA PRELIMINAR}

Reproducimos a continuación "Le chêne de l'Ogre", cuento beréber, recogido y traducido al francés por la escritora Taos Amrouche, publicado en el libro Le grain magique, contes, poèmes et proverbes de Kabylie, París, La Découverte/Poche, 1996. Hicimos traducción al castellano en 2004 en el marco de una actividad cultural realizada por la «Asociación Presencia Argelina».

Se cuenta que en tiempos remotos, había un anciano que se empeñaba a vivir y a esperar la muerte, solo en su casucha. Vivía fuera del pueblo y jamás entraba ni salía, porque estaba paralizado. Había arrastrado su cama hasta la puerta para poder tirar del pestillo, con ayuda de un hilo. Ese anciano tenía una nietecita, a penas salida de la infancia, que le llevaba todos los días su almuerzo y su cena. Aïcha venía desde la otra punta del pueblo, enviada por sus padres que no podían cuidar del anciano.

La niña le llevaba una torta y un plato de cuscús y cantaba nada más llegar:

-Ábreme la puerta, ¡oh, Baba Inuba, oh Baba Inuba!

Y el abuelo respondía:

- Haz sonar tus pulseritas, Aïcha, hija mía.

La niña hacía chocar sus pulseras, una contra otra y entonces el abuelo tiraba del pestillo. Aïcha entraba, barría la casucha, ventilaba la cama, luego servía al viejo su almuerzo y le daba de beber. Después de estar con él mucho tiempo, se marchaba, le dejaba sereno y a punto de dormirse. La niña contaba todos los días a sus padres cómo había cuidado de su 
abuelo y todo lo que le había contado para distraerle. El abuelo gustaba mucho verla llegar.

Pero un día, el Ogro vio a la niña, la siguió a escondidas hasta la casucha y la oyó cantonear:

—Ábreme la puerta, ¡oh, Baba Inuba, oh Baba Inuba! —oyó al viejo contestar:

- Haz sonar tus pulseritas, Aïcha, hija mía.

El Ogro pensó: Ya sé. Mañana volveré, repetiré las palabras de la pequeña, el abuelo me abrirá y lo comeré.

Al día siguiente, antes de que la niña llegara, el Ogro se presentó frente a la casucha y dijo con su voz ronca:

—Ábreme la puerta, ¡oh, Baba Inuba, oh Baba Inuba!

—Lárgate, maldito! - le contestó el viejo. ¿Crees que no te he reconocido?

El Ogro volvió muchas veces, pero el viejo, cada vez, adivinaba quién era hasta que, al final, el Ogro fue a ver al brujo.

- Hay un viejo impotente, le dijo el Ogro, que vive fuera del pueblo. No quiere abrirme porque mi voz ronca me traiciona, indícame la manera de tener una voz tan fina y clara como la de su nieta.

El brujo respondió:

-Úntate la garganta de miel y túmbate en el suelo, al sol, con la boca bien abierta. Las hormigas entrarán y aclararán tu garganta, pero, en un solo día, tu voz no se aclarará.

El Ogro hizo lo que le recomendó el brujo: compró miel, se llenó la garganta y se tumbó al sol con la boca bien abierta. Un ejército de hormigas entró en su garganta.

Después de dos días, el Ogro se acercó a la casucha y cantó:

-Ábreme la puerta, ¡oh, Baba Inuba, oh Baba Inuba!

Pero el anciano le reconoció una vez más.

—iLárgate, maldito! —le gritó—, sé quién eres.

El Ogro se marchó.

Comió más y más miel. Se tumbó horas y horas al sol. Dejó que legiones de hormigas entrasen en su garganta y saliesen de ella. Al cuarto día su voz se aclaró tanto como la de la nieta. El Ogro se acercó de nuevo a casa del anciano y cantó: 
-Ábreme la puerta, ¡oh, Baba Inuba, oh Baba Inuba!

-Haz sonar tus pulseras, Aïcha, hija mía — contestó el anciano.

El Ogro que traía con él una cadena, la hizo sonar. La puerta se abrió, el Ogro entró y devoró al anciano, luego vistió su ropa, tomó su asiento y esperó a la nieta para devorarla también.

Y la nieta llegó. Pero en cuanto llegó a la casucha, se dio cuenta de que había sangre que corría debajo de la puerta, y pensó: “¿Qué le habrá pasado a mi abuelo?”. Cerró la puerta desde el exterior y cantó:

-Ábreme la puerta, ¡oh, Baba Inuba, oh Baba Inuba!

El Ogro respondió con su voz fina y clara:

- Haz sonar tus pulseras, Aïcha, hija mía.

La niña que no reconoció la voz de su abuelo, dejó la torta y el cuscús en el suelo y corrió hacia el pueblo para alertar a sus padres.

-El Ogro se ha comido al abuelo — gritó llorando. He cerrado la puerta y él está dentro, y ahora, ¿qué vamos a hacer?

El padre salió para anunciar la noticia en la plaza pública. Entonces, cada familia ofreció un haz de leña y todos los hombres acudieron, de todas partes, para llevar la leña hasta la casucha e incendiarla. El ogro intentó huir, derrumbando la puerta pero no lo consiguió y así fue como murió quemado.

$\mathrm{Al}$ año siguiente, en el mismo lugar donde fue quemado el ogro, un roble creció, y se le llamó "el roble del Ogro", que, desde entonces, se enseña a los visitantes.

Mi cuento es como un arroyo, y lo he contado a caballeros. 



\section{Criterios de edición:}

Revista Argelina. Revista semestral de Estudios Argelinos es una publicación electrónica e impresa evaluada por pares con tres criterios de selección: I) aceptación; 2) aceptación con cambios; 3) devolución. Se aceptan contribuciones en castellano, valenciano, árabe, francés e inglés.

Los originales se presentarán registrándose como usuario y subiendo el documento a la plataforma ojs de gestión del proceso editorial en el sitio web: https://argelina.ua.es

El aparato crítico deberá ajustarse a las siguientes normas de edición:

-Texto en formato estándar a un espacio de interlineado.

-Fuente en Romanas (Times New Roman) a I2 puntos.

-Título del trabajo en mayúsculas a I6 puntos seguido en línea inferior por el nombre del autor en versalitas.

-Notas a pie de página a ro puntos.

-Cita: Libro (Nombre, Título, Ciudad, Editorial, Año); Artículo (Nombre, “Título”, en Revista, Año, vol. x, núm.x, pp. xx).

-Sistema internacional para las citas y transcripciones del árabe. 


\section{معايير النشر :}

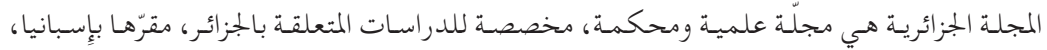

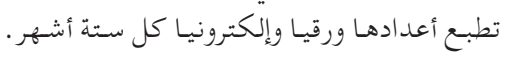

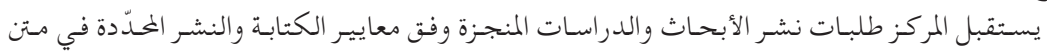
هـذه الوثيقـة.

- تخضع المواد المرسلة كلّها للتّقييم والقراءة الأكاديميّة . - في حال الموافقة، يُجري الكاتب التعديلات كليات المقترحة قبل تسليم المادّة للتحرير النّهائي.

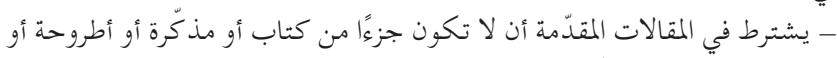

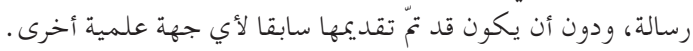

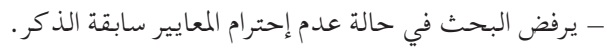

يمكن المساهمة باللغات التالية : العربيّة، الإِسبانية، الفرنسية، الفلنسيانية والإِنجليزيّة.

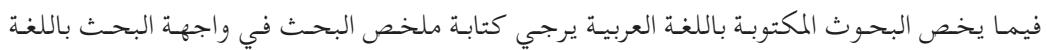

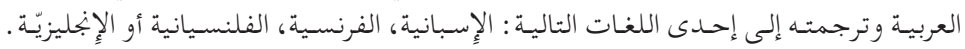

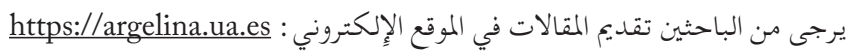

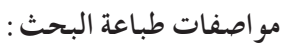

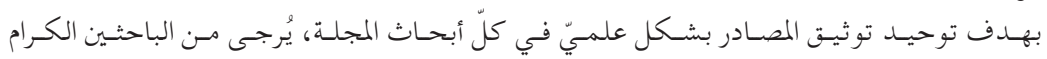

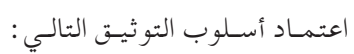

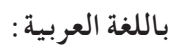

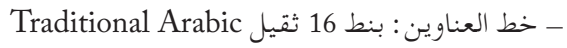

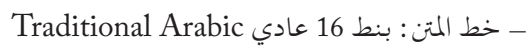

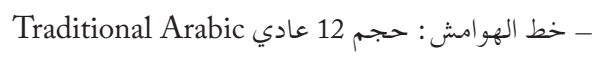
باللغات اللاتينية: - تنسيق النص القياسي في مسافة سطر . بالغات

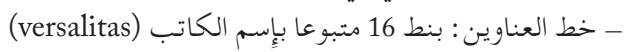
- خط المتن: بنط 12 عادي (Times New Roman)

- الإشارة إلى الهو امش أسفل الصفحة بالطريقة الالكترونية، بنط 10 (Times New Roman)

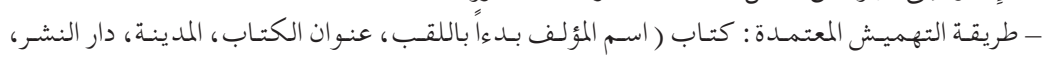

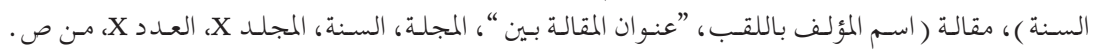

- يرجى استعمال النظام الدولي للتعيينات والنصوص العربية . - يلي كل مقالة قائمة المراجع والمصادر المعتمدة عليها في البحثث. 



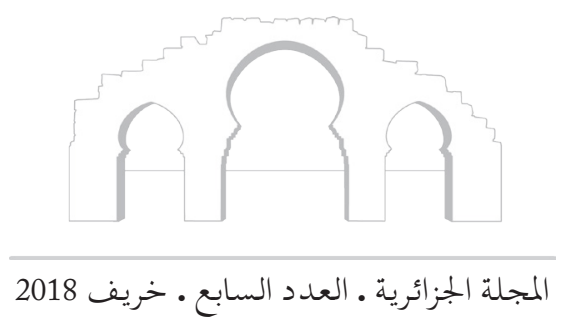

فهر ست

مقالات

بن زغادي محمد

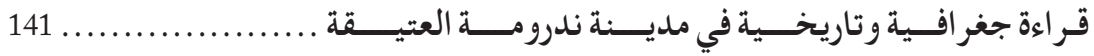

عباسـة طاهـر ويوسفي محمد وبن عزوز ربيعة

مساهمة التحكيـم التجاري الدوليفي تفعيل الأمن القانوني للاستثمار المجز ائري بالحارج ... 



$$
\text { العدد السابع • خريف } 2018
$$

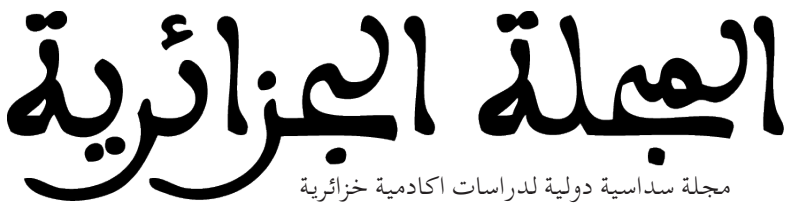




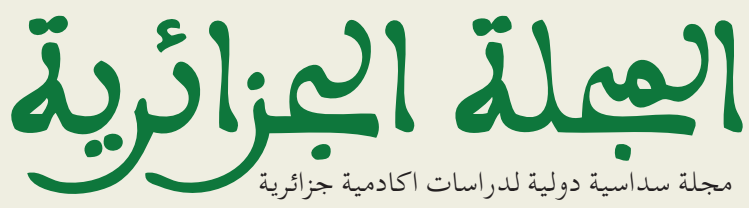

\section{ÍNDICE}

\section{Ensayos}

Souad Hadj-Ali Mounoub

El ritual de la boqala. Una tradición oral argelina

Mohammed Yousfi

Relaciones políticas entre Argelia y España antes de la colonización francesa

\section{Artículos y notas}

Mourad Kacimi

Análisis crítico sobre el Naf̣̣ al-țīb min-guṣn al-Andalus al-rațîb de al-Maqqarī

Djamel Latroch

Malteses en Argelia (1833-1900): entre el rechazo y la aceptación

Faiza Mechernene

El léxico español en Aïn Temouchent

Antonio Torres Fernández

Traduciendo a Wāsiñī al-A'raŷ: un estudio mitocrítico del dualismo léxico en su obra Bayt al-Andalusī. 101

IsAac Donoso

Argelia y los estudios árabes en Alicante (III): Marcelino Villegas

Sarra IKram HadeF

Carta del miquilache Sidi Hasán (1786): edición y traducción

\section{Reseñas y comentarios bibliográficos}

Óscar Abenojar, Ouahiba Immoune y Fatima-Zohra Menas, La princesa cautiva y el pájaro del viento. Mitos y cuentos del norte de Argelia (A. Torres Fernández)

\section{Biblioteca}

La historia de Harún Al-Rashid. Narrada por Mohammed Kandouci (1925-2008).Grabada, transcrita y traducida del árabe al castellano por Laredj Kandouci

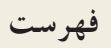

